UNIVERSIDADE DE SÃO PAULO

INSTITUTO DE GEOCIÊNCIAS

\title{
HIDROTERMALISMO EVIDENCIADO POR MINERAIS AUTIGÊNICOS E INCLUSÕES FLUIDAS \\ DA FORMAÇÃO TERESINA, BACIA DO PARANÁ
}

\author{
SARA FERREIRA NOMURA \\ Orientador: Prof. Dr. André Oliveira Sawakuchi
}

DISSERTAÇÃO DE MESTRADO

Programa de Pós-Graduação em Geoquímica e Geotectônica

\author{
SÃO PAULO \\ 2013
}

VERSÃO CORRIGIDA 
Ficha catalográfica preparada pelo Serviço de Biblioteca e Documentação do Instituto de Geociências da Universidade de São Paulo

Nomura, Sara Ferreira

Hidrotermalismo evidenciado por minerais autigênicos e inclusões fluidas da Formação Teresina, Bacia do Paraná / Sara Ferreira Nomura. São Paulo, 2012

146 p.: il

Dissertação (Mestrado) : IGc/USP

Orient.: Sawakuchi, André Oliveira

1. Hidrotermalismo 2. Inclusões fluidas 3. Formação Teresina 4. Bacia do Paraná 5. Magmatismo Serra Geral I. Título 
"We find no vestige of a beginning, no prospect of an end"

(James Hutton, Theory of the Earth, 1788) 


\section{AGRADECIMENTOS}

Ao meu orientador, prof. Dr. André Oliveira Sawakuchi, pela valiosa orientação e amizade. Pelas oportunidades oferecidas, pelas críticas construtivas, pelos ensinamentos transmitidos e pelas importantes discussões e idéias que incentivaram diversas pesquisas na busca por respostas. Por ter dado todo suporte para que a finalização desta dissertação fosse possível, apesar das dificuldades surgidas pelo caminho. Seu apoio, suas sugestões, sua confiança e disponibilidade foram alicerces importantes para a conclusão de mais esta orientação.

À Dra. Rosa Maria da Silveira Bello, do Laboratório de Inclusões Fluidas do IGc-USP, pela importante orientação na etapa analítica das inclusões fluidas, pelos ensinamentos teóricos e práticos, pela participação e apoio na aquisição dos dados, pelas fundamentais discussões nas interpretações dos dados e principalmente pela sua postura científica ao pesquisar com empenho e dedicação a aplicação do estudo de inclusões fluidas em diversas áreas da geologia, procurando auxiliar da melhor maneira àqueles a quem ela orienta. Em especial, agradeço pela amizade conquistada durante este período que será lembrada pelo agradável convívio no dia-a-dia.

À amiga Johanna Méndez Duque especialmente pela amizade e pela companhia nos momentos de trabalho de campo, laboratório e de lazer. Pelas dicas, sugestões e apoio sempre bem vindos e por ser exemplo de dedicação e generosidade.

À Manuela Pinheiro Ferreira (Pinhão) e à Alexandra Fernandes Oliveira pela amizade e companhia nas atividades de campo e de laboratório.

Às amigas de sala Ximena, Milene e Rosana pela companhia e pelas conversas descontraídas durante minhas rápidas passagens.

Aos amigos, professores e a todos àqueles que passaram por mim durante minha graduação e mestrado, pelo aprendizado, crescimento e amadurecimento durante esses mais de sete anos de convívio no Instituto de Geociências. Em especial aos amigos que estiveram mais presentes no dia-a-dia: Giovanna (Furadeira), Renata (Chouriço), Vitor (Tainá), Marcelo (Imbecil), Diego (Pescador), Pedro (Morsa), Fernanda (Minancora), Danilo (Gonzo), Guilherme (Sol), Flávio (Entupido), Juli Sucapuca, Rodolfo (Pinky), Rafaela (Bilóba), Aline (Massa), Johanna Méndez e John Rico.

Ao geólogo Ideval do Museu de Geociências do IGc-USP pela atenção, carisma e pelas palavras de incentivo. 
Ao Dr. Kazuo Fuzikawa do Centro de Desenvolvimento de Tecnologia Nuclear (CDTN - Belo Horizonte - MG) por ter sido sempre gentil, atencioso e muito solicito. Pelo apoio, disponibilidade e participação nas etapas analíticas das inclusões fluidas.

A Dra. Sylvia Dantas, pela disponibilidade e execução das análises de inclusões fluidas por espectrometria Raman no Laboratório de Espectroscopia Raman - Departamento de Engenharia Metalúrgica e de Materiais - da Universidade Federal de Minas Gerais (UFMG).

Ao engenheiro Dr. Isaac Jamil Sayeg, responsável pelo Laboratório de Microscopia Eletrônica de Varredura (MEV) do IGC, pelo apoio e fornecimento dos dados de análises químicas.

Ao prof. Dr. Daniel Atencio pelas análises de raios-X e por ter permitido que eu tivesse os primeiros contatos com um trabalho de pesquisa científica durante a graduação, com a Iniciação Científica.

Ao prof. Dr. Fábio Ramos Dias de Andrade pelas análises de raios-X.

Ao químico Marcos Mansueto do Laboratório de Microssonda Eletrônica e ao técnico de laboratório Paulo Roberto Molinaro pelo apoio na confecção de lâminas.

Aos professores doutores Renato Paes de Almeida, Setembrino Petri, André Oliveira Sawakuchi e Paulo César Boggiani pelas aulas ministradas no curso de PósGraduação.

Aos funcionários da Biblioteca do IGc-USP pelas instruções e por facilitar 0 acesso aos livros, artigos e mapoteca, em especial à Sandra e a Brenda pela atenção e simpatia.

Aos amigos de trabalho da Petrobrás que conheci após ingressar na empresa ainda durante a realização desta dissertação. Pela força e pelas palavras de incentivo para que eu conseguisse conciliar a pesquisa de mestrado em paralelo ao curso de formação fornecido para os geólogos recém chegados à empresa. Em especial agradeço ao Vinícius Carbone e ao Matheus Cuglieri pelo auxílio na edição das figuras.

À amiga Cláudia Regina Gasque Schoof pela amizade, por ter compatilhado momentos importantes de minha vida e por estar sempre na torcida mesmo à distância.

À minha família (irmã, avós, tios e primos) pela companhia em muitos e bons momentos de convívio, principalmente durante minha infância, pelas diversas vezes que me apoiaram ou me ajudaram de alguma forma e por estarem sempre na torcida para que eu chegasse até aqui. Agradeço especialmente aos meus pais, Takashi e Leonarda, pelo amor e carinho incondicionais, por estarem sempre presentes se esforçando para oferecer o que de melhor acreditavam que seria para mim, pelos 
cuidados e proteção, pela educação e pelos incentivos para que eu alcançasse objetivos. Apesar da jornada ter sido difícil algumas vezes, foram momentos importantes para nosso crescimento e união. Agradeço por sempre me oferecerem a base e a segurança para que eu alcançasse muitas das minhas (nossas) realizações. Esta conquista também é de vocês!

Ao Conselho Nacional de Desenvolvimento Científico e Tecnológico (CNPq) pela concessão da bolsa de mestrado.

A Fundação de Amparo à Pesquisa do Estado de São Paulo (FAPESP) pelo financiamento do projeto (2009/52270-6).

Enfim, agradeço a todos àqueles que de algum jeito participaram, me apoiaram e deram oportunidades para que eu pudesse dar mais este passo em meu crescimento acadêmico e pessoal. 


\section{RESUMO}

A Formação Teresina na borda leste da Bacia do Paraná inclui fácies terrígenas e carbonáticas, as quais se destacam pela diversidade e quantidade de produtos autigênicos. Isto inclui calcedônia pervasiva e cimentos e veios de quartzo e calcita.Os componentes de ocorrência mais restrita abrangem barita, celestita, analcima, dolomita, interestratificados de esmectita-ilita, saponita e betume sólido. Os veios de calcita e quartzo são predominantemente verticais. Porém, salienta-se a ocorrência de veios horizontais de calcita paralelos ao acamamento (veios beef). Análises petrográficas foram utilizadas para caracterização dos componentes autigênicos e de suas relações texturais. Análises de inclusões fluidas foram realizadas em calcita e quartzo autigênicos para estimar paleotemperaturas e caracterizar a composição dos paleofluidos aquosos e hidrocarbonetos identificados. A silicificação por calcedônia afeta principalmente as fácies de calcários e teria ocorrido durante a eodiagênese possivelmente influenciada por eventos hidrotermais permotriássicos. As paragêneses minerais formadas por barita, dolomita e calcita blocosa em cavidade de dissolução em chert nodular brechado e calcita espática, barita, celestita e analcima em calcário recristalizado estão de acordo com possível origem hidrotermal. A reativação de falhas profundas pela propagação intraplaca dos esforços ligados à Orogenia La Ventana na borda sul do Gondwana e o impacto de Araguainha provocariam importantes alterações térmicas em ampla área da bacia e poderiam gerar zonas de hidrotermalismo durante o Permo-Triássico. Temperaturas de homogeneização de inclusões fluidas em calcita e quartzo indicam que a Formação Teresina e a Formação Corumbataí, unidade correlata à Formação Teresina no norte da área estudada, alcançaram temperaturas de no mínimo $200^{\circ} \mathrm{C}$, possivelmente até $400^{\circ} \mathrm{C}$. Geminação do tipo fragmentada (patch) em cristais de calcita de veios horizontais e verticais indicam deformação a temperaturas maiores que $200^{\circ} \mathrm{C}$. Inclusões fluidas em calcita e quartzo das formações Teresina e Corumbataí registram paleofluidos aquosos de salinidade baixa (0-5\% em peso equivalente de $\mathrm{NaCl})$ a alta (20-25\% em peso equivalente de $\mathrm{NaCl}$ ). Inclusões fluidas aquosas de alta salinidade associadas a inclusões de hidrocarbonetos leves indicam a migração de paleofluidos de alta profundidade em zonas de fratura da Formação Corumbataí. Inclusões fluidas de salinidade baixa indicariam paleofluidos de origem meteórica. Paleotemperaturas maiores que $200^{\circ} \mathrm{C}$ na Formação Teresina são relativamente altas para serem alcançadas somente por soterramento na borda leste da Bacia do Paraná. O mesmo acontece para a ocorrência de interestratificados de esmectita-ilita, que requerem 
temperaturas entre 80 e $125^{\circ} \mathrm{C}$. A ampla área de ocorrência e o registro destas paleotemperaturas em veio de calcita em dique básico permitem atribuí-las ao aquecimento pelo magmatismo Serra Geral durante o Eocretáceo. Fluidos com diferentes salinidades em áreas adjacentes indicam a falta de comunicação horizontal e restrição dos paleofluidos a caminhos verticais de migração. Assim, a migração seria principalmente vertical e ocorreria em compartimentos separados por falhas e zonas de fraturas verticais geradas ou reativadas durante os eventos tectônicos do PermoTriássico e Cretáceo. Os veios beef estariam associados a compartimentos com sobrepressão na Formação Teresina, que permitiram a saída de águas de poro de alta salinidade, possivelmente combinada com a geração e expulsão de hidrocarbonetos durante o magmatismo Serra Geral. Fraturas verticais de direção NW a NNW e NE a NNE seriam os principais caminhos de migração dos fluidos aquosos de poros e de hidrocarbonetos, além de permitirem a entrada de água meteórica em zonas mais profundas. Essas fraturas estariam associadas principalmente à descontinuidades do embasamento reativadas, onde as falhas da Jacutinga (NE) e de Guapiara (NW) representariam as principais estruturas da área estudada. O betume sólido que preenche fraturas de direção NW na Formação Teresina corresponderia a hidrocarbonetos líquidos termicamente alterados (pirobetume) pelo magmatismo Serra Geral. A espessura reduzida das unidades sedimentares situadas entre a Formação Teresina e as rochas magmáticas da Formação Serra Geral no flanco norte do Arco de Ponta Grossa, nas áreas de Jacarezinho-Joaquim Távora (PR) e de Taguaí-Fartura (SP), propiciaria efeito térmico mais intenso da capa de basalto sobre a Formação Teresina.

Palavras-chave: hidrotermalismo, inclusões fluidas, Formação Teresina, Bacia do Paraná, magmatismo Serra Geral. 


\begin{abstract}
The Permian Teresina Formation in the eastern flank of the Paraná Basin stands out due to the diversity and high content of autigenic products. These products include pervasive calcedony and cements and veins of quartz and calcite, associated with other autigenic minerals that comprise barite, celestite, analcime, dolomite, illitesmectite interstratification and saponite. The Teresina Formation also stands for the occurrence of several horizontal parallel-bedding calcite veins (beef veins), besides solid bitumen and light hydrocarbons. Petrographic analysis under optical microscope and scan electron microscope coupled with an EDS attachment were used to recognize autigenic minerals and their textural relationships. Fluid inclusions analysis were performed in the main autigenic minerals (calcite and quartz) to estimate paleotemperatures and to acquire the composition of aqueous paleofluids and hydrocarbons. The intense silicification of the limestones of the Teresina Formation would have happened during eodiagenesis, possibly associated with hydrothermal events. The reactivation of deep faults due to, the propagation of intraplate stress from the La Ventana Orogeny in the southern border of Gondwana and the Araguainha impact event would have caused important thermal alterations in a wide area of the basin, promoting hidrothermal activity during the Permo-Triassic. Barite, dolomite and blocky calcite paragenesis in dissolution cavities from brecciated nodular chert and spar calcite, barite, celestite and high temperature analcime paragenesis in recrystallized limestone are in agreement with a possible hydrothermal origin. Homogenization temperatures of fluid inclusions from calcite and quartz show that the Teresina Formation and the Corumbataí Formation, which is correlated to the Teresina Formation in the northern portion of the studied area, reached temperatures of at least $200^{\circ} \mathrm{C}$, possibly until $400^{\circ} \mathrm{C}$. Patch twins in calcite veins also indicate deformation under temperatures above $200^{\circ} \mathrm{C}$. The Teresina and Corumbataí formations record inclusions in calcite and quartz with low $(0-5 \mathrm{wt} . \% \mathrm{NaCl}$ eq.) to high $(20-25 \mathrm{wt} . \% \mathrm{NaCl}$ eq.) salinity aqueous paleofluids. The high salinity aqueous inclusions associated with light hydrocarbons inclusions indicate migration of deep buried paleofluids in fractures zones within the Corumbataí Formation. The low salinity aqueous fluids suggest the input of meteoric water to deep zones. Paleotemperatures higher than $200^{\circ} \mathrm{C}$ in the Teresina Formation are relatively high to be reached by burial in the eastern border of the Paraná. Basin. The same is interpreted through the occurrence of cements made by illite-smectite interstratification, which requires temperatures between 80 and $125^{\circ} \mathrm{C}$. These paleotemperatures are attributed to the heating due to the Serra Geral
\end{abstract}


magmatism during the Early Cretaceous. Fluids with different salinities in neighbor areas show the lack of horizontal fluid flux communication. Thus, fluid migration would be mainly vertical and restricted to compartments separated by faults or vertical fracture zones generated or reactivated by tectonic events during Permo-Triassic and Cretaceous. The beef veins indicate the development of overpressured compartments in the Teresina Formation, which allowed the output of buried high salinity pore waters, combined with hydrocarbon generation and expulsion during the Early Cretaceous Serra Geral heating event. Vertical NW to NNW and NE to NNE fractures would be the main pathways for the migration of buried pore waters and hydrocarbons, besides the input of meteoric water. These fractures would be associated to the reactivation of basement discontinuities. The Jacutinga (NE) and Guapiara (NW) faults and associated fractures would represent the main pathways for fluid migration in the studied area. The solid bitumen filling NW fractures in the Teresina Formation would correspond to thermally altered liquid hydrocarbons (pyrobitumen). The reduced thickness of the stratigraphical units between the Teresina and Serra Geral formations in the northern flank of the Ponta Grossa Arch, which includes the JacarezinhoJoaquim Távora (PR) and Taguaí-Fartura (SP) areas, improved the thermal effect of the basalt cap on the underlying Permian units, allowing a high temperature regional thermal background.

Keywords: hidrothermalism, fluid inclusions, Teresina Formation, Paraná Basin, Serra Geral magmatism. 


\section{SUMÁRIO}

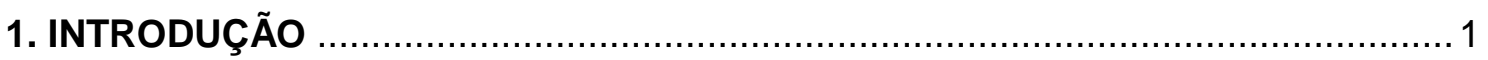

2. OBJETIVOS

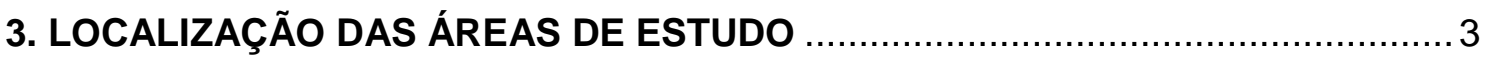

4. MATERIAIS E MÉTODOS

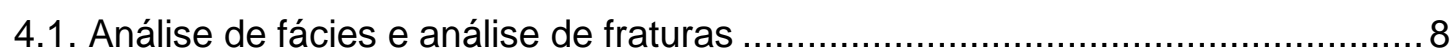

4.2. Microscopia óptica e eletrônica de varredura .................................................. 8

4.3. Microtermometria e teste de esmagamento................................................. 10

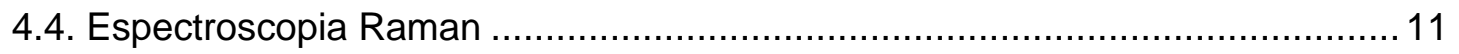

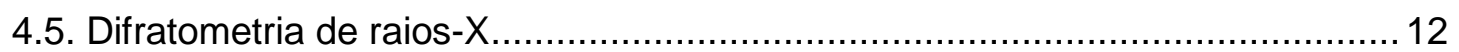

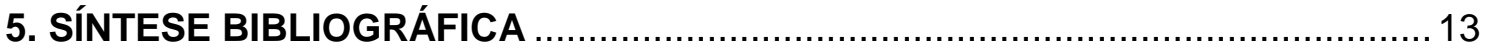

5.1. A Bacia do Paraná e o contexto estratigráfico da Formação Teresina.............. 13

5.2. Geologia estrutural da faixa de afloramentos da Formação Teresina no Estado de São Paulo e norte do Estado do Paraná ............................................................. 16

5.3. Diagênese - Definições, conceitos, processos e produtos ............................... 18

5.4. Fluidos hidrotermais - Definição, origem e paragêneses minerais em bacias

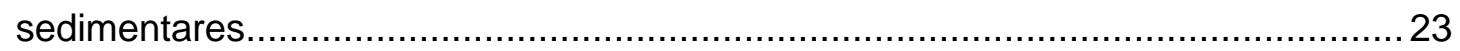

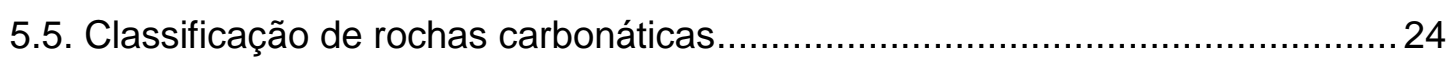

5.6. Análise de inclusões fluidas aplicada ao estudo da diagênese .........................25

5.6.1. Comportamento de inclusões fluidas aquo(salinas) em ambientes diagenéticos de diferentes pressões e temperaturas ....................................... 28

5.6.2. Características das inclusões fluidas aprisionadas em ambientes diagenéticos de baixa e alta temperatura e suas modificações devido à reequilíbrios posteriores................................................................................. 30

6. RESULTADOS

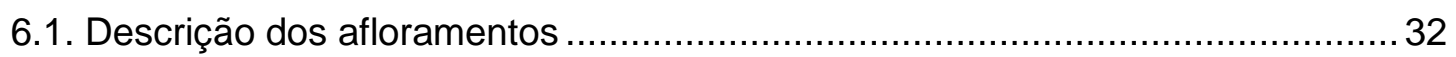

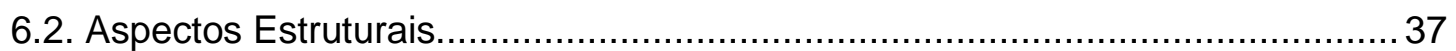

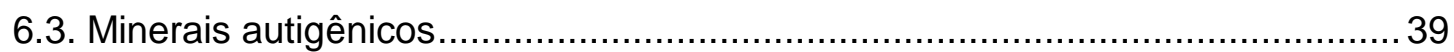

6.3.1. Componentes silicosos (quartzo e calcedônia - $\mathrm{SiO}_{2}$ ) ...............................39

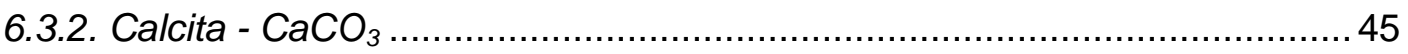

6.3.3. Dolomita - (Ca, Mg) $\mathrm{CO}_{3}$ e pseudomorfos de calcita .................................52

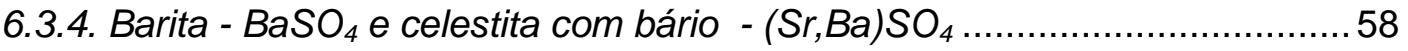

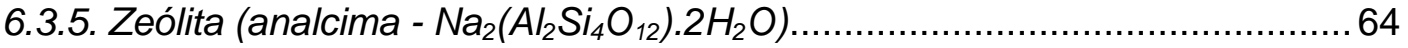

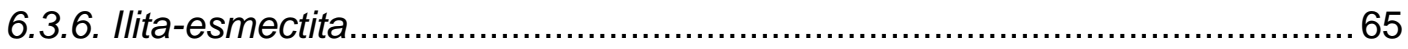

6.3.7. Esmectita (saponita $-\mathrm{Ca}_{0,1} \mathrm{Na}_{0,2} \mathrm{Fe}_{1,1} \mathrm{MgAlSi}_{3,6} \mathrm{O}_{10}(\mathrm{OH})_{2}$ ) .........................6 67

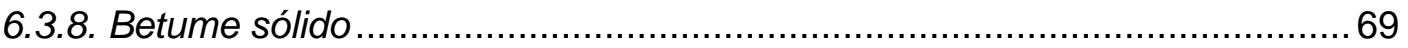




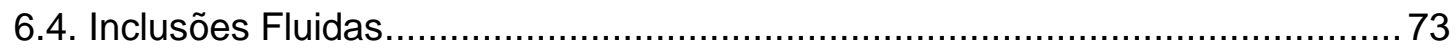

6.4.1. Inclusões em veios de calcita horizontal (Taguaí, SP) ..............................73

6.4.2. Inclusões em calcita espática de cavidades de dissolução de packstone/grainstone oolítico brechado (Taguaí, SP) .........................................79

6.4.3. Inclusões em veio de calcita vertical de dique básico do magmatismo Serra Geral (Fartura, SP)

6.4.4. Inclusões em cristal de quartzo de geodo de cone silicoso (Anhembi, SP) 81

6.4.5. Inclusões em calcita de fenda de tração (Jacarezinho, $P R$ ).

6.4.6. Inclusões em calcita blocosa (blocky) de cavidades de dissolução de chert nodular brechado (Jacarezinho, PR).....

6.4.7. Inclusões em romboedros de calcita espática (Jacarezinho, PR)..... .88

6.4.8. Inclusões em calcita de fratura vertical (entre Santo Antonio da Platina e Joaquim Távora, PR)

6.4.9. Inclusões em veio de quartzo da Formação Corumbataí (Ipeúna, SP).......91

\section{DISCUSSÕES}

7.1. Origem dos minerais autigênicos.

7.1.1. Calcita.

7.1.2. Calcedônia e quartzo .98

7.1.3. Dolomita e pseudomorfos de calcita 101

7.1.4. Barita e celestita 102

7.1.5. Zeólita (analcima) 103

7.1.6. Ilita-esmectita e esmectita (saponita)...... 104

7.1.7. Betume sólido. 105

7.2. Paleotemperaturas 107

7.3. Composição e origem dos paleofluidos 115

7.4. Eventos hidrotermais nas formações Teresina e Corumbataí. 118

7.5. Eventos hidrotermais nas formações Teresina e Corumbataí no contexto da evolução tectônica da Bacia do Paraná. 120

7.6. Considerações sobre a geração e migração de hidrocarbonetos na Bacia do Paraná 127 133 


\section{INTRODUÇÃO}

A Formação Teresina (Permiano, Bacia do Paraná) compreende sucessão sedimentar terrígeno-carbonático-evaporítica (Méndez, 2012) depositada em mar epicontinental do sudoeste do Gondwana. Na borda leste da Bacia do Paraná entre o centro-leste do Estado de São Paulo e o norte do Estado do Paraná, a Formação Teresina é a principal unidade de topo do Grupo Passa Dois e encontra-se sobreposta ao Subgrupo Irati e à Formação Serra Alta e sotoposta à Formação Pirambóia (Milani et al., 2007; Holz et al., 2010). Nestas áreas, destaca-se a intensa cimentação silicosa e carbonática das fácies da Formação Teresina, sugestiva de intensa ação de processos diagenéticos. Yamamoto et al. (2005) interpretam estruturas cônicas silicosas aflorantes na região de Anhembi como produto da atividade de gêiseres permianos (geiseritos). Turra (2009) atribui a elevada concentração de diques clásticos na Formação Teresina no Estado de São Paulo como resultado da atividade sísmica permiana ligada à reativação da falha da Jacutinga. Nomura (2009) e Nomura et al. (2010) descreveram recentemente a ocorrência de betume sólido na Formação Teresina na região de Fartura (SP), cuja gênese estaria ligada à alteração térmica de hidrocarbonetos. Sant'anna et al. (2006) reconhecem a existência de sistema hidrotermal de escala regional, o qual teria afetado a sucessão permiana da bacia durante o Eocretáceo. Sistemas hidrotermais em bacias sedimentares são importantes principalmente pela capacidade de geração de zonas de dissolução e pelo transporte de íons e calor a longas distâncias. Isto resulta numa assinatura específica na história diagenética dessas bacias. Quando esses sistemas hidrotermais têm sua origem associada a intrusões ígneas são mais efetivos e duradouros a depender do volume da intrusão, da frequência dos fluxos de lava, da porosidade e permeabilidade do meio rochoso e do volume de água disponível, sendo este último o mais importante dos fatores (Biondi, 2003). Quando a quantidade de água é insuficiente, um corpo ígneo volumoso e portanto, com elevada capacidade para geração de calor, tem sua atuação limitada às proximidades da zona de contato com a rocha encaixante (Biondi, 2003). Assim, a água é o fator determinante para o transporte de calor e solutos a grandes distâncias em sistemas hidrotermais (Biondi, 2003). Sistemas hidrotermais podem excercer papel importante em sistemas petrolíferos de bacias sedimentares, especialmente em relação às características permo-porosas dos reservatórios. Fluidos hidrotermais de alta temperatura tem grande potencial de dissolução e por isso são muito efetivos na geração de porosidade secundária. Entretanto, é importante que haja sincronismo com a migração de óleo para que essa porosidade não seja obliterada pela cimentação de minerais hidrotermais. No contexto de sistema petrolífero, a 
Formação Teresina situa-se entre as rochas geradoras do Irati e os reservatórios arenosos do Pirambóia (Franzinelli, 1972; Thomaz-Filho, 1982; Araújo 2003). A migração dos hidrocarbonetos gerados no Subgrupo Irati até os arenitos da Formação Pirambóia tem como caminho falhas que cortam a Formação Teresina. Segundo Araújo et al. (2000), a expulsão dos hidrocarbonetos a partir dos folhelhos do Subgrupo Irati seria altamente influenciada por condições de sobrepressão impostas pelo recobrimento dos folhelhos por selantes diagenéticos (fácies silicificadas e cimentadas por calcita) das formações Serra Alta e Teresina. Assim, os produtos autigênicos da Formação Teresina podem registrar processos de superfície e subsuperfície atuantes na Bacia do Paraná desde o Permiano, capazes de afetar o fluxo térmico e a interação rocha-fluido em subsuperfície, tais como o impacto de Araguainha durante o Permo-Triássico (Tohver et al., 2012) e o magmatismo Serra Geral durante o Eocretáceo (Thiede \& Vasconcelos, 2010). Apesar de existirem diversas questões ligadas à evolução pós-deposicional da Formação Teresina, são raros os estudos específicos sobre este tema.

Este trabalho visa o estudo da evolução pós-deposicional da Formação Teresina nas regiões de Anhembi, Fartura e Taguaí no Estado de São Paulo e Jacarezinho, Santo Antonio da Platina e Joaquim Távora no Estado do Paraná. Também inclui a Formação Corumbataí na região de Ipeúna (SP). Para isto, são empregados métodos de análises mineralógicas e de inclusões fluidas em minerais autigênicos de amostras de afloramentos. A análise de inclusões fluidas fornece informações sobre a composição e evolução térmica de paleofluidos (McLimans, 1987; Goldstein \& Reynolds, 1994; Munz, 2001; Coelho, 2004). Neste estudo, a análise de inclusões fluidas associada a dados texturais e composicionais dos produtos autigênicos, estruturais e de fácies foram utilizados para avaliar a história térmica e os paleofluidos da Formação Teresina e a relação destes com a evolução da Bacia do Paraná.

\section{OBJETIVOS}

A meta desta pesquisa é a elaboração de modelo sobre a evolução térmica e os paleofluidos da Formação Teresina na borda leste da Bacia do Paraná, a norte do eixo do Arco de Ponta Grossa. Para isto enfatizou-se o estudo de componentes autigênicos, visando o reconhecimento de suas relações texturais e genéticas, além do estudo de associações de inclusões fluidas aquosas e de hidrocarbonetos presentes em quartzo e calcita autigênicos. Isto envolveu as seguintes tarefas: 1) 
Descrição e coleta de amostras em termos de fácies sedimentares, horizontes estratigráficos e feições estruturais, tais como corpos ígneos, sistemas de juntas e lineamentos tectônicos; 2) Caracterização textural e composicional de materiais autigênicos; 3) Análises petrográficas, microtermométrica e de esmagamento de inclusões fluidas de minerais autigênicos; 4) Análises composicionais de fluidos diagenéticos aprisionados como inclusões. Apesar do foco deste trabalho ter sido a Formação Teresina, alguns afloramentos da Formação Corumbataí também foram estudados com a finalidade de avaliar, em caráter preliminar, possíveis correlações na história térmica e paleofluidos das duas formações.

\section{LOCALIZAÇÃO DAS ÁREAS DE ESTUDO}

As áreas de estudo estão situadas na borda leste da Bacia do Paraná, a norte do eixo do Arco de Ponta Grossa, entre o centro-leste do Estado de São Paulo e o norte do Paraná e compreendem os municípios de Ipeúna, Anhembi, Taguaí, Fartura (SP) e Jacarezinho, Santo Antonio da Platina e Joaquim Távora (PR). O alinhamento de Guapiara (Ferreira et al., 1981) e a falha da Jacutinga (Soares, 1991) são as principais estruturas tectônicas, na escala de centenas de quilômetros, que cruzam as áreas estudadas (Figura 1). Destaca-se ainda a ocorrência de diversos altos estruturais, tais como os domos de Pitanga (Ipeúna) e Anhembi. A Tabela 1 indica a localização dos afloramentos estudados (latitude/longitude; município), seu número de referência nos mapas geológicos dos estados de São Paulo e Paraná (figuras 2 e 3) e o código das amostras coletadas.

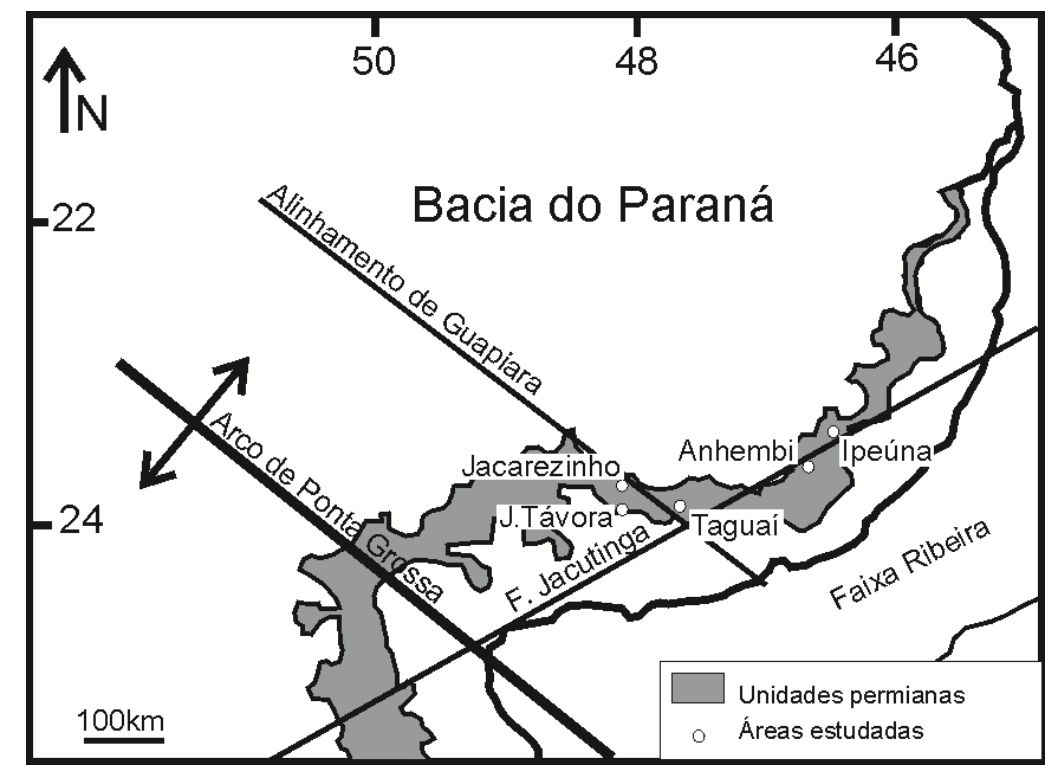

Figura 1. As áreas estudadas estão situadas sobre a zona de afloramento das unidades permianas da borda leste da Bacia do Paraná a norte do eixo do Arco de 
Ponta Grossa. O alinhamento (magmático) de Guapiara e a falha da Jacutinga são as principais estruturas tectônicas das áreas estudadas.

Tabela 1. Localização dos afloramentos estudados e o código das amostras coletadas. A primeira coluna identifica a localização dos afloramentos nos mapas das figuras 2 e 3.

\begin{tabular}{|c|c|c|c|c|c|c|}
\hline \multicolumn{7}{|c|}{ ESTADO DE SÃO PAULO } \\
\hline $\begin{array}{l}\text { Localização } \\
\text { no mapa }\end{array}$ & Unidade & $\begin{array}{l}\text { Latitude } \\
\left({ }^{\circ}\right)\end{array}$ & $\begin{array}{l}\text { Longitude } \\
\qquad\left(^{\circ}\right)\end{array}$ & Município & Afloramento & $\begin{array}{c}\text { Código } \\
\text { da } \\
\text { amostra }\end{array}$ \\
\hline 1 & $\begin{array}{c}\text { Formação } \\
\text { Teresina }\end{array}$ & $23^{\circ} 22^{\prime} 22 " \mathrm{~S}$ & $49^{\circ} 29^{\prime} 41^{\prime \prime} \mathrm{W}$ & Fartura & $\mathrm{JZ}-15$ & $\mathrm{JZ}-15 \mathrm{~A}$ \\
\hline 2 & $\begin{array}{c}\text { Formação } \\
\text { Teresina }\end{array}$ & $23^{\circ} 22^{\prime} 09^{\prime \prime} \mathrm{S}$ & $49^{\circ} 29^{\prime} 10^{\prime \prime} \mathrm{W}$ & Fartura & $J Z-16$ & $J Z-16 A$ \\
\hline \multirow{6}{*}{3} & \multirow{6}{*}{$\begin{array}{c}\text { Formação } \\
\text { Teresina }\end{array}$} & \multirow{6}{*}{$23^{\circ} 28^{\prime} 24^{\prime \prime} \mathrm{S}$} & \multirow{6}{*}{$49^{\circ} 19^{\prime} 48^{\prime \prime} \mathrm{W}$} & \multirow{6}{*}{ Taguaí } & \multirow{6}{*}{ IP-06 } & TER-03 \\
\hline & & & & & & TER-07 \\
\hline & & & & & & TER-09 \\
\hline & & & & & & IP-06-R7 \\
\hline & & & & & & $\mathrm{T}-1$ \\
\hline & & & & & & TA-GL \\
\hline 4 & $\begin{array}{c}\text { Formação } \\
\text { Teresina }\end{array}$ & $23^{\circ} 27^{\prime} 49^{\prime \prime} \mathrm{S}$ & $49^{\circ} 20^{\prime} 42^{\prime \prime} \mathrm{W}$ & Taguaí & IP-32 & - \\
\hline 5 & $\begin{array}{c}\text { Formação } \\
\text { Teresina }\end{array}$ & $23^{\circ} 27^{\prime} 45^{\prime \prime} \mathrm{S}$ & $49^{\circ} 20^{\prime} 49^{\prime \prime} \mathrm{W}$ & Taguaí & IP-37 & - \\
\hline 6 & $\begin{array}{c}\text { Formação } \\
\text { Teresina }\end{array}$ & $23^{\circ} 27^{\prime} 51^{\prime \prime} \mathrm{S}$ & $49^{\circ} 20^{\prime} 33^{\prime \prime} \mathrm{W}$ & Taguaí & IP-39 & - \\
\hline 7 & $\begin{array}{c}\text { Formação } \\
\text { Teresina }\end{array}$ & $23^{\circ} 22^{\prime} 28^{\prime \prime} \mathrm{S}$ & $48^{\circ} 12^{\prime} 33^{\prime \prime} \mathrm{W}$ & Guareí & IP-19 & - \\
\hline 8 & $\begin{array}{c}\text { Formação } \\
\text { Teresina }\end{array}$ & $23^{\circ} 21^{\prime} 28^{\prime \prime} \mathrm{S}$ & $48^{\circ} 14^{\prime} 53^{\prime \prime} \mathrm{W}$ & Guareí & IP-20 & - \\
\hline 9 & $\begin{array}{c}\text { Formação } \\
\text { Teresina }\end{array}$ & $23^{\circ} 20^{\prime} 42^{\prime \prime} \mathrm{S}$ & $48^{\circ} 12^{\prime} 12^{\prime \prime} \mathrm{W}$ & Guareí & IP-13 & - \\
\hline 10 & $\begin{array}{c}\text { Formação } \\
\text { Teresina }\end{array}$ & $23^{\circ} 13^{\prime} 49^{\prime \prime} \mathrm{S}$ & $48^{\circ} 09^{\prime} 48^{\prime \prime} \mathrm{W}$ & $\begin{array}{c}\text { Porangaba/ } \\
\text { Guareí }\end{array}$ & IP-07 & - \\
\hline 11 & $\begin{array}{c}\text { Formação } \\
\text { Teresina }\end{array}$ & $22^{\circ} 56^{\prime} 15^{\prime \prime} \mathrm{S}$ & $48^{\circ} 10^{\prime} 11^{\prime \prime} \mathrm{W}$ & Pirambóia & IP-24 & - \\
\hline 12 & $\begin{array}{c}\text { Formação } \\
\text { Teresina }\end{array}$ & $22^{\circ} 46^{\prime} 26^{\prime \prime} \mathrm{S}$ & $48^{\circ} 11^{\prime} 02^{\prime \prime} \mathrm{W}$ & Anhembi & IP-25 & - \\
\hline 13 & $\begin{array}{c}\text { Formação } \\
\text { Teresina }\end{array}$ & $22^{\circ} 45^{\prime} 36^{\prime \prime} \mathrm{S}$ & $48^{\circ} 10^{\prime} 48^{\prime \prime} \mathrm{W}$ & Anhembi & IP-22 & IP-22B \\
\hline 14 & $\begin{array}{c}\text { Formação } \\
\text { Teresina }\end{array}$ & $22^{\circ} 45^{\prime} 30^{\prime \prime} \mathrm{S}$ & $48^{\circ} 10^{\prime} 27^{\prime \prime} \mathrm{W}$ & Anhembi & IP-23 & - \\
\hline 15 & \begin{tabular}{|c|} 
Formação \\
Corumbataí
\end{tabular} & $22^{\circ} 25^{\prime} 04^{\prime \prime} \mathrm{S}$ & $47^{\circ} 42^{\prime} 52^{\prime \prime} \mathrm{W}$ & Ipeúna & MS-1 & MS-1 \\
\hline 16 & \begin{tabular}{|c|} 
Formação \\
Corumbataí
\end{tabular} & $22^{\circ} 31^{\prime} 07^{\prime \prime} \mathrm{S}$ & $47^{\circ} 34^{\prime} 20^{\prime \prime} \mathrm{W}$ & Limeira & IP-29 & - \\
\hline 17 & $\begin{array}{l}\text { Formação } \\
\text { Corumbataí }\end{array}$ & $22^{\circ} 32^{\prime} 43^{\prime \prime} \mathrm{S}$ & $47^{\circ} 26^{\prime} 30^{\prime \prime} \mathrm{W}$ & Limeira & IP-44 & - \\
\hline \multicolumn{7}{|c|}{ ESTADO DO PARANÁ } \\
\hline $\begin{array}{l}\text { Localização } \\
\text { no mapa }\end{array}$ & Unidade & Latitude $\left({ }^{\circ}\right)$ & Longitude $\left(^{\circ}\right)$ & Município & Afloramento & $\begin{array}{c}\text { Código } \\
\text { da } \\
\text { amostra }\end{array}$ \\
\hline \multirow[t]{2}{*}{1} & \multirow{2}{*}{$\begin{array}{c}\text { Formação } \\
\text { Teresina }\end{array}$} & \multirow{2}{*}{$23^{\circ} 09^{\prime} 36^{\prime \prime} \mathrm{S}$} & \multirow{2}{*}{$49^{\circ} 57^{\prime} 38^{\prime \prime} \mathrm{W}$} & \multirow{2}{*}{ Jacarezinho } & \multirow{2}{*}{ JZ-02 } & JZ-02C \\
\hline & & & & & & JZ-02D \\
\hline
\end{tabular}




\begin{tabular}{|c|c|c|c|c|c|c|}
\hline 2 & $\begin{array}{c}\text { Formação } \\
\text { Teresina }\end{array}$ & $23^{\circ} 10^{\prime} 16^{\prime \prime} \mathrm{S}$ & $49^{\circ} 58^{\prime} 05^{\prime \prime} \mathrm{W}$ & Jacarezinho & $\mathrm{JZ}-03$ & $J Z-03 B$ \\
\hline 3 & $\begin{array}{c}\text { Formação } \\
\text { Teresina }\end{array}$ & $23^{\circ} 10^{\prime} 11^{\prime \prime} \mathrm{S}$ & $49^{\circ} 58^{\prime} 27^{\prime \prime} \mathrm{W}$ & Jacarezinho & $\mathrm{JZ}-04$ & $\mathrm{JZ}-04 \mathrm{~A}$ \\
\hline \multirow{4}{*}{4} & \multirow{4}{*}{$\begin{array}{c}\text { Formação } \\
\text { Teresina }\end{array}$} & \multirow{4}{*}{$23^{\circ} 09^{\prime} 43^{\prime \prime} \mathrm{S}$} & \multirow{4}{*}{$49^{\circ} 58^{\prime} 03^{\prime \prime} \mathrm{W}$} & \multirow{4}{*}{ Jacarezinho } & \multirow{4}{*}{ JZ-05 } & $\mathrm{JZ}-05$ \\
\hline & & & & & & $\mathrm{JZ}-05 \mathrm{~A}$ \\
\hline & & & & & & JZ-05C \\
\hline & & & & & & $\mathrm{JZ}-05 \mathrm{D}$ \\
\hline \multirow{2}{*}{5} & \multirow{2}{*}{$\begin{array}{c}\text { Formação } \\
\text { Teresina }\end{array}$} & \multirow{2}{*}{$23^{\circ} 20^{\prime} 12^{\prime \prime} \mathrm{S}$} & \multirow{2}{*}{$50^{\circ} 00^{\prime} 36^{\prime \prime} \mathrm{W}$} & \multirow{2}{*}{$\begin{array}{c}\text { Santo } \\
\text { Antonio } \\
\text { da Platina } \\
\end{array}$} & \multirow{2}{*}{ JZ-07 } & JZ-07A \\
\hline & & & & & & JZ-07E \\
\hline \multirow{3}{*}{6} & \multirow{3}{*}{$\begin{array}{c}\text { Formação } \\
\text { Teresina }\end{array}$} & \multirow{3}{*}{$23^{\circ} 23^{\prime} 46^{\prime \prime} \mathrm{S}$} & \multirow{3}{*}{$50^{\circ} 02^{\prime} 28^{\prime \prime} \mathrm{W}$} & \multirow{3}{*}{$\begin{array}{l}\text { Joaquim } \\
\text { Távora }\end{array}$} & \multirow{3}{*}{ JZ-10 } & $\mathrm{JZ}-10 \mathrm{C}$ \\
\hline & & & & & & $\mathrm{JZ}-10 \mathrm{D}$ \\
\hline & & & & & & $\mathrm{JZ}-10 \mathrm{G}$ \\
\hline 7 & $\begin{array}{c}\text { Formação } \\
\text { Teresina }\end{array}$ & $23^{\circ} 28^{\prime} 35^{\prime \prime} \mathrm{S}$ & $49^{\circ} 55^{\prime} 40^{\prime \prime} \mathrm{W}$ & $\begin{array}{l}\text { Joaquim } \\
\text { Távora }\end{array}$ & JZ-13 & $J Z-13 C$ \\
\hline
\end{tabular}

As figuras 2 e 3 apresentam respectivamente o mapa geológico da porção centro-leste do Estado de São Paulo e da porção norte do Estado do Paraná. Notar a distribuição dos calcários da Formação Teresina e siltitos da Formação Corumbataí, além dos corpos ígneos intrusivos, derrames basálticos da Formação Serra Geral e as principais feições estruturais (diques, falhas e fraturas). Na Figura 2, os afloramentos visitados estão divididos entre quatro regiões de estudo: 1) Taguaí/Fartura; 2) Guareí/Porangaba; 3) Anhembi e 4) Ipeúna/Rio Claro. A Figura 3 compreende os afloramentos estudados entre os municípios de Jacarezinho, Santo Antônio da Platina e Joaquim Távora (PR). 


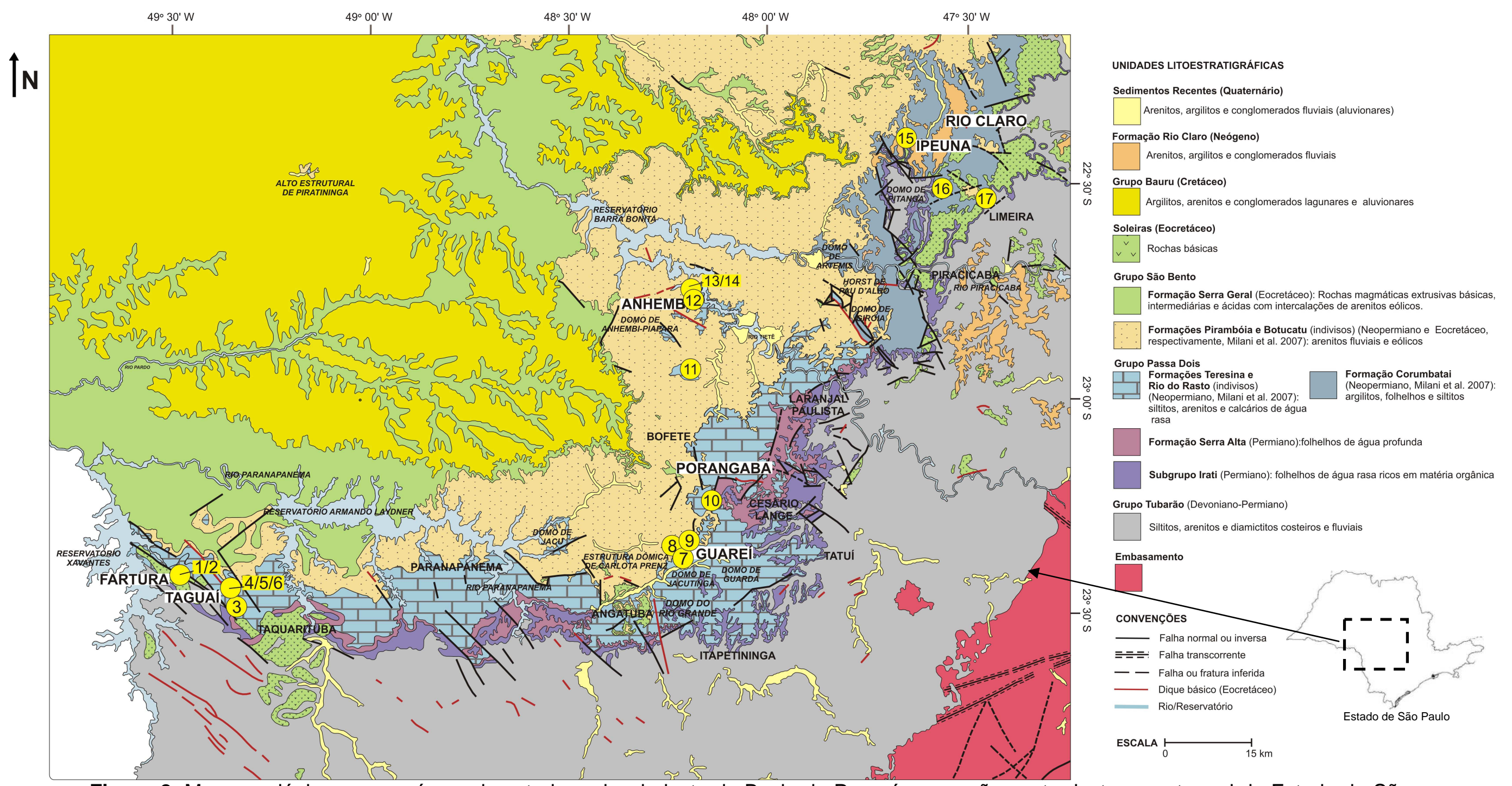

Figura 2. Mapa geológico com as áreas de estudo na borda leste da Bacia do Paraná na porção centro-leste e centro-sul do Estado de São Paulo, onde estão compreendidas as áreas de Taguaí-Fartura, Guareí-Porangaba, Anhembi e Ipeúna-Rio Claro. Os círculos com preenchimento em amarelo correspondem aos afloramentos estudados. Modificado do Mapa Geológico do Estado de São Paulo - Escala 1:500.000. 1981. (IPT, 1981). 

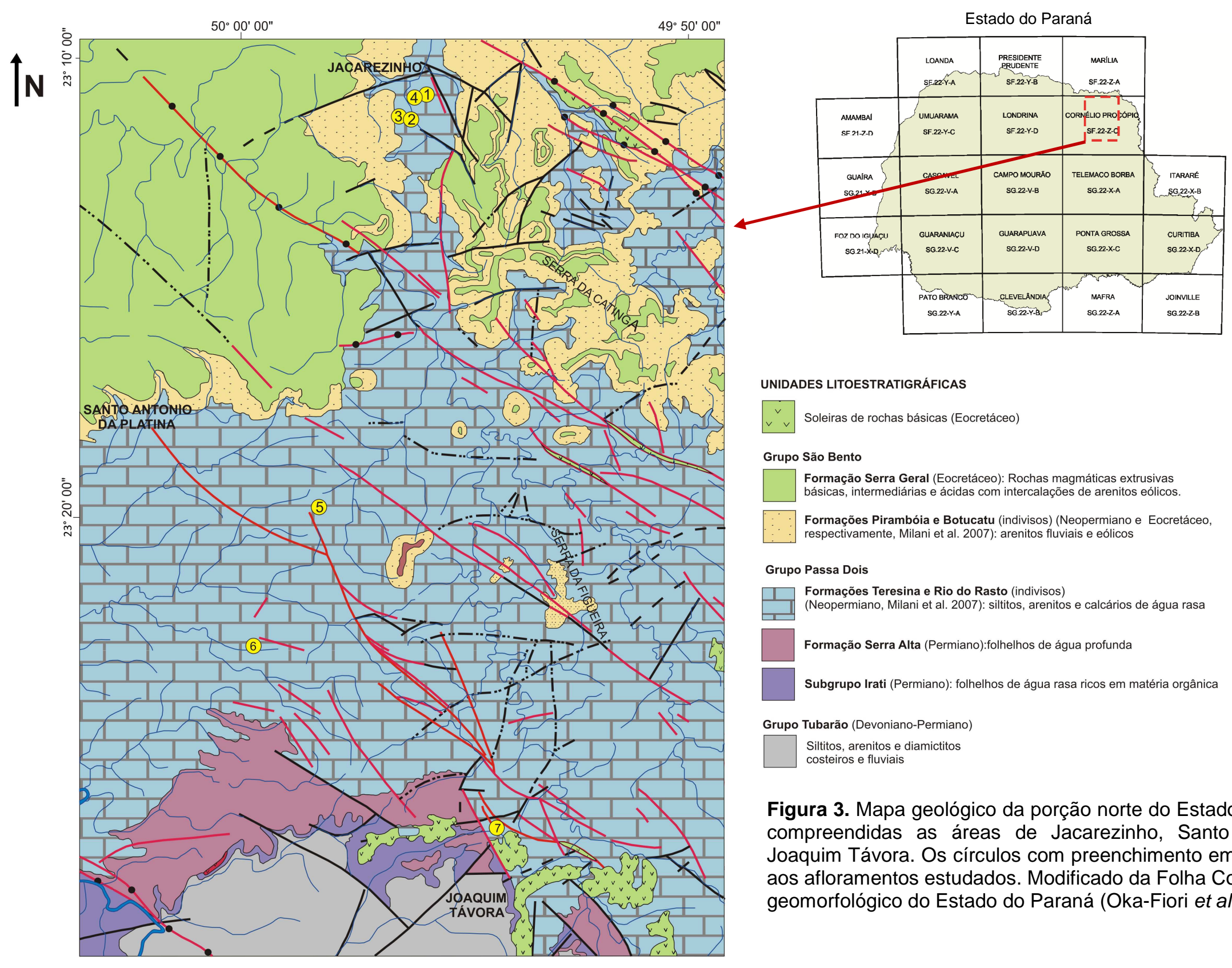

UNIDADES LITOESTRATIGRÁFICAS

$\checkmark v$ Soleiras de rochas básicas (Eocretáceo)

Grupo São Bento

Formação Serra Geral (Eocretáceo): Rochas magmáticas extrusivas
básicas, intermediárias e ácidas com intercalaçōes de arenitos eólicos.

Formações Pirambóia e Botucatu (indivisos) (Neopermiano e Eocretáceo

Formações Piramboia e Botucatu (indivisos) (Neopermiano
respectivamente, Milani et al. 2007): arenitos fluviais e eólicos

\section{Grupo Passa Dois}

Formaçōes Teresina e Rio do Rasto (indivisos)
(Neopermiano, Milani et al. 2007): siltitos, arenitos e calcários de água rasa

Formação Serra Alta (Permiano):folhelhos de água profunda

Subgrupo Irati (Permiano): folhelhos de água rasa ricos em matéria orgânica

Siltitos, arenitos e diamictitos
costeiros e fluviais

Figura 3. Mapa geológico da porção norte do Estado do Paraná, onde estão compreendidas as áreas de Jacarezinho, Santo Antônio da Platina e Joaquim Távora. Os círculos com preenchimento em amarelo correspondem aos afloramentos estudados. Modificado da Folha Cornélio Procópio do Atlas geomorfológico do Estado do Paraná (Oka-Fiori et al., 2006).

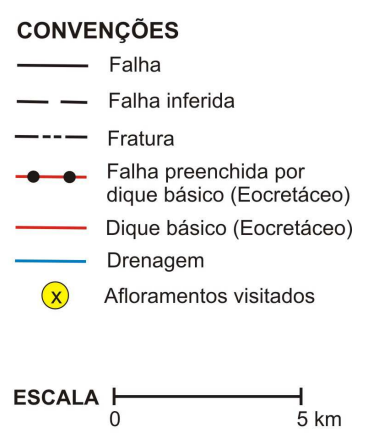

CONVENÇÕES

- Falha inferida

- Falha preenchida por

- Dique básico (Eocretáceo)

- Drenagem

$5 \mathrm{~km}$ 


\section{MATERIAIS E MÉTODOS}

\subsection{Análise de fácies e análise de fraturas}

Os afloramentos estudados foram descritos de forma a distinguir as principais fácies sedimentares, com atenção voltada para observação das relações dessas fácies com a ocorrência de minerais autigênicos e feições pós-deposicionais, tais como zonas com cimentação, diques e fraturas. Rumos de mergulho e espaçamento de fraturas foram medidos para avaliar a relação entre as estruturas deformacionais em escala de afloramento e os lineamentos estruturais descritos na bibliografia. As direções de fraturas medidas em afloramento e de diques estão apresentadas em diagramas de roseta. Esses dados foram comparados segundo suas estatísticas descritivas. Amostras das fácies sedimentares e de minerais de preenchimento de fraturas (calcita e quartzo) foram coletadas para estudos petrográficos e de inclusões fluidas. Assim, o estudo das relações texturais e das inclusões fluidas desses componentes autigênicos e suas associações com feições estruturais possibilitaram a elaboração de modelo sobre a evolução térmica e dos paleofluidos da Formação Teresina. A correlação dessas feições estruturais observadas em campo com eventos tectônicos regionais foram importantes principalmente para posicionamento temporal e inferência dos possíveis caminhos de percolação desses fluidos.

\subsection{Microscopia óptica e eletrônica de varredura}

Vinte e quatro seções delgadas confeccionadas a partir das amostras coletadas em afloramentos foram analisadas em microscópio de luz polarizada para descrição da textura e composição. Além disso, a morfologia, espessura e freqüência de geminações nos cristais de calcita foram obtidas visando estimar as temperaturas de deformação do cristal de acordo com o método proposto por Ferril et al. (2004). Microscopia com epifluorescência UV foi usada para descrição de componentes orgânicos como betume e inclusões fluidas de hidrocarbonetos.

Após descrição petrográfica, onze seções delgadas foram selecionadas para análises detalhadas por microscopia eletrônica de varredura (MEV) e espectroscopia de energia dispersiva (EDS). A seguir é descrito um resumo sobre o funcionamento da microscopia eletrônica de varredura:

$\mathrm{Na}$ microscopia eletrônica de varredura incide-se um feixe de elétrons sobre a amostra cuja interação libera várias radiações (elétrons secundários, elétrons retroespalhados, raios-X e outros), de modo que cada tipo de radiação é captado por um detector específico. Detectores de elétrons secundários permitem a formação de 
imagens da região analisada com informações de morfologia e topografia com alta magnitude e resolução, enquanto os detectores de elétrons retroespalhados, imagens com variações composicionais. $\mathrm{Na}$ imagem formada por elétrons retroespalhados, as variações composicionais são visualizadas em diferentes tons de cinza, de modo que os tons mais claros apresentam maior peso atômico médio e os mais escuros, menor peso atômico médio. A análise por EDS permite a identificação composicional da amostra. Neste caso, a incidência de um feixe de elétrons sobre um ponto da amostra atinge os átomos que a constituem neste local, o que leva a excitação de elétrons e íons e à mudanças de níveis enérgicos. Com isto, ocorre consequente liberação de energia em comprimentos de ondas de raios- $X$, de modo que cada elemento químico presente libera uma energia específica que permite identificá-lo. $O$ dado obtido de cada ponto analisado é um gráfico, onde a coordenada $x$ corresponde a valores de energia (keV) e a coordenada y aos de intensidade (I) e uma tabela composicionail semi-quantitativa. A tabela composicional semiquantitativa apresenta percentuais de peso atômico (\%), de proporção atômica (\%) e de elementos na forma de óxidos (calculados estequiometricamente) e normalizados para $100 \%$. Outra possibilidade é a geração de mapas composicionais com a distribuição espacial de elementos químicos. O detector de EDS tem algumas limitações: 1) detecta elementos químicos apenas com massa atômica superior ao do boro e que estejam presentes em concentração superior a $1 \%$; 2) os elementos C, B, N, O, F e Ne apesar de detectáveis, não são bem quantificados; 3) alguns elementos podem apresentar mesmo valor de energia (ex: Ag e Th); 4) alguns elementos influenciam na ionização de outros elementos (ex: influência do Fe sobre $\mathrm{Cr}$ ).

Neste trabalho, a microscopia eletrônica de varredura foi emrpegada para reconhecer minerais autigênicos não identificados durante a microscopia óptica, o que permitiu melhor caracterização da composição e relação textural entre esses cimentos. Estas análises também possibilitaram a descoberta de outros minerais observáveis somente na escala do MEV e forneceram uma descrição mais precisa do tamanho e geometria dos poros. As análises MEV-EDS foram efetuadas com microscópio LEO 4401, no Laboratório de Microscopia Eletrônica de Varredura do Instituto de Geociências da Universidade de São Paulo. O feixe de elétrons operou com as seguintes condições: tensão de aceleração de $20 \mathrm{kV}$, variação de corrente entre 500 pA à 2,5 nA, tempo de aquisição de 100 s e diâmetro do feixe de aproximadamente 2 $\mu \mathrm{m}$ para análises de maiores resoluções. 


\subsection{Microtermometria e teste de esmagamento}

Amostras para os estudos de inclusões fluidas foram selecionadas após análise petrográfica. Primeiramente, as seções delgadas foram estudadas sob microscópio de luz polarizada com o propósito de definir a origem das inclusões fluidas (primária, pseudo-secundária e secundária) e suas condições de aprisionamento (zona vadosa, zona saturada de baixa ou alta temperatura) de acordo com os critérios propostos por Goldstein \& Reynolds (1994). A petrografia das inclusões fluidas também foi necessária para selecionar inclusões fluidas para microtermometria, com exclusão daquelas com feições de escape (leakage) e estiramento (necking down). Posteriormente, com os campos escolhidos, prosseguiu-se com a análise microtermométrica das inclusões fluidas, através de medidas de aquecimento (homogeneização) e resfriamento (ponto eutético e fusão do gelo). As temperaturas de homogeneização total do fluido $(\mathrm{TH})$ são obtidas quando o sistema se uniformiza para apenas uma fase durante o ensaio de aquecimento. Essas temperaturas foram utilizadas para estimativa de temperaturas mínimas de aprisionamento ou de reequilíbrio dos fluidos diagenéticos aprisionados. A temperatura do ponto eutético (TE) registra o início da fusão da solução salina congelada e indica a composição do sistema aprisionado, por meio dos tipos de íons dissolvidos na solução. A TE ocorre quando se observa, sob o microscópio, uma mudança sutil e contínua na textura da solução salina congelada. A visualização dessa mudança é difícil e sua exatidão depende das dimensões e nitidez das inclusões, da salinidade, uma vez que em inclusões pouco salinas as mudanças texturais são mais sutis, e principalmente da habilidade do operador. A temperatura de fusão do gelo (TFG) é de $0^{\circ} \mathrm{C}$ para $\mathrm{H}_{2} \mathrm{O}$ pura, mas quando há sais no sistema ocorre diminuição desta temperatura. Portanto, de acordo com a TFG é possível determinar a salinidade dos fluidos aquosos aprisionados, sendo expressa como equivalente à porcentagem em peso do $\mathrm{NaCl}$. Para a determinação da salinidade foi empregado o aplicativo BULK do software FLUIDS (Bakker, 2003), o qual utiliza equações de estado escolhidas de acordo com a composição do sistema e valores das variáveis TFG e TH ou da proporção do volume da fase líquida.

A microtermometria das inclusões fluidas foi realizada em platina de resfriamento e aquecimento CHAIXMECA MTM 85, no Laboratório de Inclusões Fluidas do Instituto de Geociências da Universidade de São Paulo. A platina foi calibrada com padrões Merck 320 Signotherm para baixas temperaturas e Merck MSP para altas temperaturas. Para as medidas das temperaturas de homogeneização, foi utilizada taxa de aquecimento de $2^{\circ} \mathrm{C} / \mathrm{min}$. As precisões estimadas são de $0,2^{\circ} \mathrm{C}$, para 
temperaturas entre -60 e $25^{\circ} \mathrm{C}$, e de $5^{\circ}$ para temperaturas entre 100 e $600^{\circ} \mathrm{C}$. Para a calcita, as medidas de aquecimento foram realizadas antes dos testes de resfriamento para estimativas de temperatura do ponto eutético e de fusão do gelo. Este procedimento visou evitar o acréscimo irreversível de volume das cavidades das inclusões (stretching) devido à cristalização do gelo, o que pode produzir valores de TH não significativos. A expansão de volume devido à formação do gelo pode causar estiramento das paredes da inclusão, especialmente em minerais de baixa dureza como os carbonatos e conseqüentemente produzir valores incorretos de TH (Goldstein \& Reynolds, 1994).

Fragmentos de betume sólido também foram aquecidos para aquisição de temperaturas de fusão e vaporização. A densidade dos fragmentos do betume foi medida utilizando-se picnômetro.

Fragmentos de seções delgadas de veios de calcita foram utilizados para ensaios de esmagamento de inclusões fluidas. O esmagamento de inclusões fluidas em glicerina permite verificar a presença de gases sob pressão no interior das inclusões, já que ao esmagá-las ocorre expansão dos gases que são liberados formando bolhas no meio circundante. Se a inclusão é composta apenas por uma solução aquosa e vapor d'agua o esmagamento provoca o colapso da bolha que desaparece instantaneamente (Roedder 1984, Fuzikawa 1985). O esmagamento de fragmentos de seções delgadas em querosene permitiu o reconhecimento de inclusões de hidrocarbonetos gasosos. Hidrocarbonetos leves são solúveis no querosene e conseqüentemente as bolhas liberadas desaparecem muito rapidamente, ao contrário de outros voláteis que apresentam solubilidades variáveis (Roedder, 1984; Fuzikawa, 1985). A liberação dos fluidos durante o esmagamento dos cristais foi observada em microscópio óptico com objetiva de 20x. Não foi possível observar a liberação individual de inclusões fluidas devido a seus tamanhos reduzidos, já que os equipamentos utilizados permitiram somente o uso de objetivas de até $20 x$.

\subsection{Espectroscopia Raman}

A espectrometria Raman possibilita a identificação dos compostos moleculares líquidos, sólidos e gasosos. $\mathrm{Na}$ análise por espectrometria Raman faz-se incidir, sobre o material a ser analisado, um feixe de luz (laser) com certa freqüência e examina-se a dispersão da luz. A maior parte da luz dispersada apresenta a mesma freqüência que a incidente (dispersão elástica de fótons), porém uma fração apresenta mudança de freqüência (dispersão inelástica - Efeito Raman) como resultado da interação da luz 
com a matéria. Essas variações de freqüência é que fornecem informações sobre a composição da amostra.

Nas análises, utilizou-se laser HeNe $(632,8 \mathrm{~nm})$, com $20 \mathrm{~mW}$ de potência, que incidiu na amostra por meio de um microscópio Olympus BX-41 (objetivas de10X, 50X e 100X). A luz espalhada foi detectada por sistema CCD (charge couple device) resfriado por nitrogênio líquido, após passar por filtro Notch (que rejeita a linha do laser) e por rede de difração $(600 \mathrm{~g} / \mathrm{mm})$. O tempo de aquisição variou entre 30 e $90 \mathrm{~s}$ e o número de aquisições foi de 5 a 10 vezes para melhorar a razão sinal/ruído.

Dentre as limitações da espectrometria Raman, encontra-se a ocorrência de fluorescência, que pode mascarar completamente o espectro, uma vez que apresenta intensidade com várias ordens de magnitude maior que o sinal do espalhamento Raman (Burke, 2001).

Assim, o estudo Raman em inclusões fluidas de hidrocarbonetos é dificultado, uma vez que a maioria deles, principalmente os mais pesados, com presença de moléculas aromáticas ou cíclicas, apresenta fluorescência. Geralmente, o reconhecimento de inclusões de hidrocarbonetos é possível com até 3 átomos de carbono, portanto dos mais leves, como o metano $\left(\mathrm{CH}_{4}\right)$ e subordinadamente dos alcanos $\left(\mathrm{C}_{2} \mathrm{H}_{6}\right.$ e $\left.\mathrm{C}_{3} \mathrm{H}_{8}\right)$ (Burke, 2001). Por outro lado, Zhang et al. (2007) demonstra que, mesmo com esta dificuldade, é possível verificar a existência de hidrocarbonetos mais pesados, pela análise dos ruídos (background), da geometria da curva espectral e de alguns picos gerados pela fluorescência desses hidrocarbonetos.

\subsection{Difratometria de raios- $X$}

A difração de raios-X permite identificar minerais através de suas estruturas cristalinas (ex: distâncias interplanares). O funcionamento do difratômetro de raios- $X \mathrm{e}$ a aquisição de dados de estruturas cristalinas ocorrem da seguinte forma: 1) ondas eletromagnéticas (raios- $X$ ) são emitidas (com comprimento de onda $(\boldsymbol{\lambda})$ definido) em certo ângulo $\boldsymbol{\theta}$ com o plano da amostra; 2) as ondas interagem com os minerais existentes na amostra através de suas distâncias interplanares e com isso ocorre a difração dos raios-X; 3 ) o detector percorre a amostra em rotação com ângulo $2 \theta$ (a depender do modelo do equipamento, é a amostra que rotaciona em torno do detector), e captura, caso ocorram, raios difratados no ângulo 20; 4) no entanto, somente serão capturados àqueles raios difratados que atendem às condições geométricas determinadas pela Lei de Bragg (equação de Bragg: $n \lambda=2 \mathbf{d}_{\mathrm{hkl}} \operatorname{sen} \boldsymbol{\theta}_{\mathrm{hkl}}$ ); 5 ) é obtido um gráfico, onde o eixo $x$ corresponde aos valores angulares $2 \theta$ e o eixo y 
corresponde aos de intensidade (I), de modo que a intensidade é maior quanto mais intensa for a difração para certo ângulo $2 \theta ; 6$ ) os valores de $2 \theta$ são convertidos em valores de distâncias interplanares (d) e esses valores são então comparados aos valores de distâncias interplanares de padrões de raios- $X$ de cristais que encontram-se reunidos em banco de dados da marca registrada JCPDS, e deste modo os minerais podem ser identificados.

Para este traablho, amostras de rocha foram fragmentadas e pulverizadas sobre lâminas de vidro $(30 \mathrm{~mm} \times 30 \mathrm{~mm})$. A difratometria de raios-X foi realizada $\mathrm{em}$ difratômetro Siemens modelo D5000 de geometria Bragg-Brentano e espelho ajustado para feixe de 0,2 mm no Laboratório de Difração de Raios X (LDRX) do Instituto de Geociências da USP. O difratômetro foi operado a 40 kV e $40 \mathrm{~mA}$, campo do goniômetro $2 q$ de 5 a $90^{\circ}$, passo de $0,02^{\circ}$, tempo de contagem de $5 \mathrm{~s} /$ passo e usando radiação CuKa $\left(1,5418^{\circ}\right)$. Os minerais foram identificados por meio de rotina computacional (EVA) de busca em banco de dados de difração de raios-X (PDF-2) adquiridos junto ao ICDD (International Centre for Diffraction Data). Os padrões do banco de dados são identificados por fichas JCPDS (Joint Committee of Powder Diffraction Standard).

\section{SÍNTESE BIBLIOGRÁFICA}

\subsection{A Bacia do Paraná e o contexto estratigráfico da Formação Teresina}

A Bacia do Paraná é uma sinéclise cratônica e abrange área com cerca de $1.500 .000 \mathrm{~km}^{2}$. Esta bacia caracteriza-se por sucessão vulcano-sedimentar que pode atingir espessura superior a $7 \mathrm{~km}$, a qual teria sido depositada entre 0 NeoOrdoviciano e o Neocretáceo. De acordo com Milani et al. (2007), discordâncias regionais possibilitam a divisão da sucessão sedimentar da Bacia do Paraná em seis superseqüências deposicionais: Rio Ivaí, Paraná, Gondwana I, Gondwana II, Gondwana III e Bauru. A Superseqüência Gondwana I compreende o Grupo Itararé, Grupo Guatá, Grupo Passa Dois e as formações Pirambóia e Sanga do Cabral (Milani et al. 2007).

A Formação Teresina pertence ao Grupo Passa Dois, que faz parte da Superseqüência Gondwana I. A porção inferior da Superseqüência Gondwana I caracterizada por depósitos glaciais do Grupo Itararé, recobertos por sedimentos transgressivos do Grupo Guatá. A porção intermediária do Grupo Passa Dois inclui os folhelhos betuminosos e calcários da Formação Irati, a qual caracteriza o fechamento da bacia ao oceano de oeste e sudoeste. Os folhelhos cinza-escuros da Formação 
Serra Alta, sobreposta à Formação Irati, caracterizariam a última incursão marinha da bacia (Milani et al., 2007). As formações Teresina, Corumbataí e Rio do Rasto resultam da fase inicial de continentalização da bacia (Holz et al., 2010). Estas unidades compreendem depósitos progradacionais predominantemente pelíticos, seguidos pelos depósitos lacustres, flúvio-eólicos e eólicos do Grupo Rosário do Sul e da Formação Pirambóia (Milani et al., 2007). Assim, a Superseqüência Gondwana I abrange um ciclo transgressivo-regressivo, que se inicia com sistemas deposicionais glaciais, atinge condições de máximo afogamento marinho, que transiciona para fase progradacional marcada pela progradação de sistemas deposicionais costeiros e continentais já no início do Mesozóico (Milani et al., 2007). Deste modo, as formações Teresina e Corumbataí representam parte da seqüência de assoreamento progressivo da bacia por sistemas deposicionais costeiros de água rasa (Holz et al., 2010), associados a sistemas fluviais e eólicos representados pelos sedimentos da Formação Pirambóia (Giannini et al., 2004).

Na região abrangida por este estudo, a Formação Teresina ocorre sobre os folhelhos da Formação Serra Alta e abaixo dos arenitos da Formação Pirambóia (Figura 4). Sobrepostos a estas unidades ocorrem os arenitos eólicos da Formação Botucatu e os derrames basálticos do magmatismo da Formação Serra Geral (Superseqüência Gondwana III, Milani et al., 2007). Os folhelhos da Formação Irati ocorrem abaixo da Formação Serra Alta.

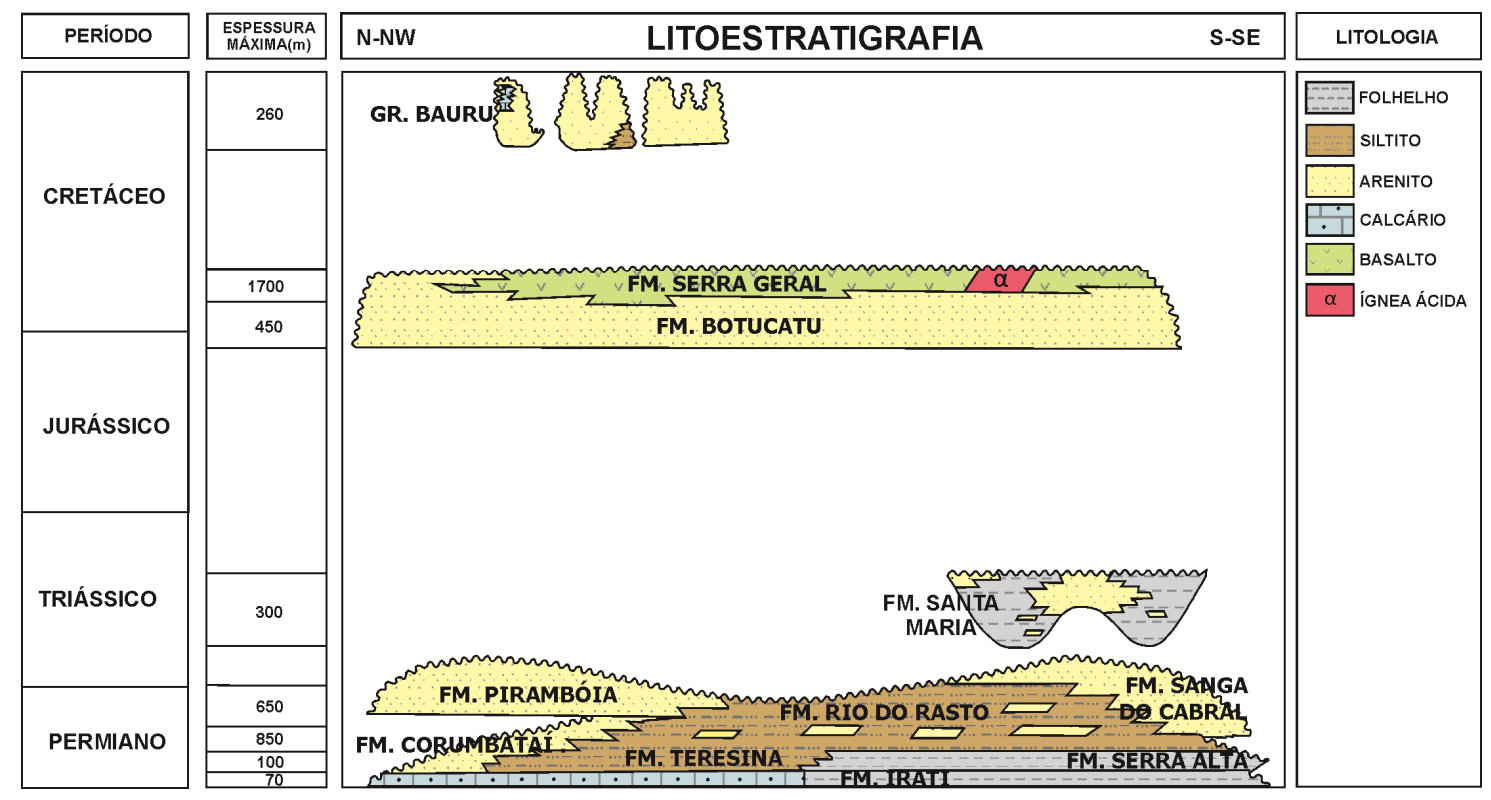

Figura 4. Coluna estratigráfica das unidades permianas e unidades posteriores da Bacia do Paraná. Adaptado de Milani et al. (2007). 
Moraes Rego (1930) empregou pela primeira vez o termo "Teresina", sob a designação de Grupo, para referir-se as rochas sedimentares encontradas na localidade tipo expostos na margem direita do Rio Ivaí, próximo à Teresa Cristina (antiga Teresina) no Paraná. Gordon Jr. (1947) categorizou a unidade como Membro da porção superior da Formação Estrada Nova. Schneider et al. (1974) considerou a unidade Teresina como Formação do Grupo Passa Dois (Mendes, 1967).

O Grupo Passa Dois constitui-se pela unidade Irati, anteriormente referida como formação e elevada à categoria de Subgrupo por Hachiro (1996), e pelas formações Serra Alta, Teresina, Rio do Rasto e Corumbataí (Schneider et al., 1974). A Formação Serra Alta é formada por argilitos, folhelhos e siltitos cinza escuro a preto com fraturas conchoidais, lentes e concreções carbonáticas. Esta unidade está situada acima dos folhelhos e argilitos cinza escuros pirobetuminosos do Subgrupo Irati (Schneider et al., 1974). A Formação Rio do Rasto compreende siltitos e arenitos finos esverdeados e arroxeados, na porção basal, e argilitos e siltitos vermelhos com intercalações de arenitos finos, no topo (Schneider et al., 1974).

Schneider et al. (1974) caracterizam a Formação Teresina pela alternância de argilitos e folhelhos com siltitos e arenitos muito finos cinza claros. Na porção basal, ocorrem folhelhos cinza escuro. No topo, ocorrem calcários, por vezes oolíticos, e leitos de coquina. Laminações onduladas, fendas de ressecamento, marcas onduladas e diques de arenitos são citados como estruturas sedimentares típicas desta unidade. Relata-se ainda a ocorrência de estruturas estromatolíticas nas camadas carbonáticas (Rohn, 1994; Méndez, 2012). O contato da Formação Teresina com a Formação Serra Alta subjacente seria concordante (Schneider et al., 1974; Holz et al., 2010). O contato entre a Formação Teresina e a Camada Porangaba, situada acima, seria transicional. Em contato, ora abrupto, ora gradual com a Formação Teresina encontram-se os arenitos da Formação Pirambóia, os quais são constituídos por arenitos médios a finos com séries métricas de estratificações plano-paralelas ou cruzadas acanaladas (Giannini et al., 2004).

Para Schneider et al. (1974), as formações Serra Alta e Teresina ocorrem do Rio Grande do Sul ao nordeste do Paraná. Almeida \& Melo (1981) estendem a zona de ocorrência destas formações até a porção centro-sul do Estado de São Paulo, onde a partir do norte do divisor de águas entre os rios Tietê e Piracicaba, as cores predominantemente cinzentas ou esverdeadas com que se apresentam no Paraná e na vizinhança de São Paulo passam a cores avermelhadas, características da Formação Corumbataí. Assim, conforme adentram o Estado de São Paulo, as formações Serra Alta e Teresina passam a corresponder à Formação Corumbataí. 
Lamelibrânquios, restos de plantas e palinomorfos apontam idade neopermiana (Kazaniano) para a Formação Teresina (Daemon \& Quadros, 1970). Os fósseis da Formação Teresina são representados principalmente por conchas de bivalves e ostracodes, mas estromatólitos, restos de peixes, espículas de esponjas, esporos e plantas também são comuns (Holz et al., 2010). A assembléia fossilífera é dominada por organismos endêmicos com afinidade a ambientes de água doce ou salina. Ghilardi \& Simões (2002) sugerem que a assembléia fossilífera da Formação Teresina é compatível com ambiente hipersalino. Isto estaria de acordo com a composição isotópica de calcários oolíticos, os quais são interpretados como sendo depositados em ambientes salinos de clima árido devido à baixa concentração de $\mathrm{Ga}$ e $\mathrm{Rb}$ e alta proporção de $\mathrm{O}^{18}$ em relação ao $\mathrm{O}^{16}$ (Suguio et al., 1974).

A partir da análise de fácies sedimentares, alguns autores propõem que a Formação Teresina corresponderia a depósitos de planície de maré (Schneider et al., 1974; Suguio et al., 1974; Petri \& Coimbra, 1982; Mello e Souza, 1985; Giannini et al., 2004). No entanto, outros autores argumentam que o registro fossilífero da Formação Teresina não seria compatível com a ligação do mar epicontinental permiano ao oceano Pantalhassa (Mendes, 1984; Simões et al.,1998; Rohn, 2001; Rohn, 2007). De acordo com Holz et al. (2010), a Formação Teresina corresponderia a sistema deposicional costeiro e de costa-afora dominado por tempestade. Méndez (2012) interpreta que as fácies carbonáticas e os silexitos da Formação Teresina do flanco norte do Arco de Ponta Grossa representariam uma rampa carbonática de águas rasas, associada a planície evaporítica.

\subsection{Geologia estrutural da faixa de afloramentos da Formação Teresina no Estado de São Paulo e norte do Estado do Paraná}

A Bacia do Paraná é compartimentada por diversos alinhamentos estruturais de direção NW-SE e NE-SW, e subordinadamente E-W (Zalán et al., 1991). Alinhamentos estruturais de direção NW-SE definem o eixo e os limites do Arco de Ponta Grossa (Strugale et al., 2007), cujo flanco norte é delimitado pela alinhamento estrutural de Guapiara. A falha da Jacutinga (NE-SW) (Soares, 1991) e o alinhamento de Guapiara (NW-SE) (Ferreira et al., 1981) constituem os principais elementos tectônicos regionais que ocorrem na área dos afloramentos estudados. Destaca-se ainda a ocorrência de diversos altos estruturais delimitados principalmente por conjuntos de falhas normais, sendo que os altos de Pitanga, Anhembi-Piapara, da 
Neblina e de Jacarezinho estão situados nas proximidades das áreas estudadas (Riccomini, 1997).

O alinhamento de Guapiara foi definido por Ferreira et al. (1981) como o limite setentrional do Arco de Ponta Grossa, de direção NW, e estaria presente desde o Devoniano. O desenvolvimento do arco teria sido responsável pela geração de novas estruturas e reativação de outras, principalmente NW e subordinadamente NE, que possibilitaram o extravasamento de lavas basálticas e a colocação de diques e soleiras associados ao evento magmático Serra Geral no Eocretáceo (Thiede \& Vasconcelos, 2010). Os municípios de Jacarezinho (PR), Joaquim Távora (PR), Fartura (SP) e Taguaí (SP) situam-se ao longo do alinhamento de Guapiara, que se destaca pela elevada concentração de diques de rochas ígneas básicas.

Zaine (1980) descreveu na região de Fartura e arredores o predomínio de alinhamentos estruturais de direção NW-SE. As estruturas NW estariam ligadas a sistema de falhamentos escalonados, geralmente preenchidos por diques de rochas ígneas máficas. Por sua vez, as estruturas subordinadas estariam relacionadas a um sistema de falhas NE, que truncam falhas de direção NW. Segundo Zaine (1980), as estruturas NE seriam produto de evento de deformação posterior ao magmatismo Serra Geral, pois não se verifica associação com diques de rochas ígneas. Zaine (1980) também descreveu sils de rochas básicas com até 20 quilômetros de extensão na região de Fartura-Taguaí (SP), os quais se encontram alojados principalmente no contato entre as unidades Tubarão-Irati e Irati-Teresina. Fúlfaro \& Suguio (1967), ao estudarem zonas de ocorrência de diques de rochas básicas na Bacia do Paraná, distinguiram três áreas em que a concentração dos diques escapa dos padrões até então referidos na literatura, sendo uma delas a região de Fartura (SP).

A falha da Jacutinga corresponde a uma falha do embasamento précambriano/eopaleozóico (Soares, 1991) da Bacia do Paraná. É a mais importante estrutura de direção NE da bacia, formada por uma faixa de fraturas com cerca de 15 km de largura, que se estende desde a região de Missiones, na Argentina, até o sul de Minas Gerais, passando pelo município de Anhembi (SP) (Soares et al., 1996).

Rostirolla et al. (2000) apresenta evidências de que a Zona de Falha da Jacutinga teria sido reativada em dois momentos após a deposição da Formação Teresina. O primeiro teria ocorrido como reflexo da propagação dos esforços compressionais intraplaca derivados da Orogenia La Ventana (Permo-Triássico), quando ocorreu a sutura da Patagonia no sul do Gondwana. Como resultado, teria ocorrido a deformação sinistral das falhas NE. O Alto Estrutural de Guatinguá, entre os 
municípios de Joaquim Távora e Curiúva (PR) corresponde a uma estrutura em florpositiva de direção NE resultante deste evento (Rostirolla et al., 2000). O segundo evento tectônico de caráter transcorrente distensivo teria afetado diques e soleiras de rochas básicas. Segundo Rostirolla et al. (2000), as falhas geradas neste evento têm direção predominantemente NW, porém com reativação local de estruturas NE ou formação de novas falhas de porte menor. No entanto, estes autores afirmam que a maior parte das falhas NE foi gerada durante o primeiro evento de deformação no permo-triássico. Rostirolla et al. (2000) também atribuem como produto do segundo evento tectônico no Eocretáceo a ocorrência de deslocamentos verticais de blocos da ordem de metros a dezenas de metros, associados a movimentos sinistrais nas falhas NW e à reativação dextral das falhas NE. Rostirolla et al. (2000) descrevem a ocorrência de diques de rochas básicas com direções predominantes NW e subordinamente NE, além de soleiras e lacólitos, provavelmente com origem relacionada ao magmatismo Serra Geral. Para estes autores, o fluxo de lava teria aproveitado tanto as estruturas mesozóicas como as anteriores, o que explicaria a ocorrência tanto ao longo das fraturas NW como NE.

Turra (2009) descreve diques clásticos de direção predominante NNE associados à atividade sísmica permiana em afloramentos da Formação Teresina na região de Limeira (SP). Este autor destaca a associação entre a faixa de ocorrência dos diques clásticos e a zona de cisalhamento da Jacutinga. Isto indicaria que a Formação Teresina no Estado de São Paulo teria sido afetada por esforços tectônicos oriundos da reativação permiana de falhas do embasamento da bacia.

\subsection{Diagênese - Definições, conceitos, processos e produtos}

A diagênese compreende processos físicos ou químicos que afetam os sedimentos ou rochas sedimentares após a deposição, mas exclui os processos que envolvam temperaturas e pressões atuantes no campo do metamorfismo (Scholle \& Ulmer Scholle, 2003). O modo como a diagênese afeta os sedimentos depende da composição e mineralogia desses sedimentos, da composição química do fluido de poro, da entrada e da taxa de fluxo dos diferentes fluidos, da história de soterramento e soerguimento do pacote rochoso e do clima predominante (Tucker \& Wright, 1990). Durante a diagênese os sedimentos carbonáticos podem ter a porosidade aumentada ou diminuída. Em geral, com o aumento da profundidade de soterramento há diminuição da porosidade, mas a ocorrência de processos de dissolução e 
faturamento, comum em rochas carbonáticas, podem restaurar ou elevar a porosidade.

Nos sedimentos carbonáticos, a diagênese tem como processos mais comuns: cimentação, micritização, neomorfismo, dissolução, compactação (mecânica e química) e dolomitização (Tucker \& Bathurst, 1990) e substituições (ex. silicificação e chertificação).

Os processos diagenéticos, quanto à profundidade de atuação, podem ocorrer em superfície ou subsuperfície e, quanto ao tempo relativo de ocorrência, podem ser precoces ou tardios.

Choquette \& Pray (1970) definem os termos eodiagênese, mesodiagênese e telodiagêse como processos diagenéticos que ocorrem em intervalos de tempo e profundidade relativamente definidos. Neste caso, a eodiagênese foi definida como processos que ocorrem na superfície ou próximos a ela e que afetam os sedimentos então depositados ou soterrados recentemente, dentro deste intervalo de tempo. A mesodiagênese corresponde aos processos diagenéticos que ocorrem em intervalo de tempo no qual os sedimentos estão soterrados a profundidades mais elevadas que àquelas relacionadas às principais influências relacionadas a superfície. A telodiagênese envolve processos que ocorrem durante o período de soerguimento ou erosão das rochas. Tucker \& Wright (1990) preferem a utilização dos termos diagênese precoce e diagênese tardia. Tucker \& Wright (1990) define a diagênese precoce como processos que ocorrem na superfície ou próximo à superfície e diagênese tardia, como os processos que ocorrem quando os sedimentos ou rochas já estão com certo grau de soterramento. Flügel (2001) define os mesmos termos (diagênese precoce e tardia) com sentido temporal, quanto ao tempo relativo ao período de deposição. Assim, a diagênese precoce é àquela que ocorre imediatamente após a deposição ou imediatamente após o início do soterramento, enquanto a diagênese tardia, após um período de tempo relativamente mais longo. Flügel (2001) não esclarece, no caso da diagênese tardia, se a definição é independente da profundidade de soterramento.

Os processos diagenéticos que ocorrem na superfície ou sob sua influência têm como principais parâmetros controladores das transformações nestas condições os relativos ao próprio ambiente deposicional (taxa de deposição, composição do fluido de poro, hidrogeologia, clima e flutuações do nível do mar), o conteúdo de matéria orgânica e a composição detrítica e textural dos sedimentos hospedeiros (Morad, 1998). Quando as rochas estão soterradas, os principais fatores controladores são a temperatura, o tempo de residência, as taxas de fluxo e de composição química 
dos fluidos de subsuperfície e a forma como a diagênese precoce atuou (Morad, 1998).

Os principais ambientes diagenéticos são o marinho, meteórico e de soterramento (Tucker \& Wright, 1990; Flügel, 2001).

A diagênese marinha ocorre no substrato marinho ou costeiro ou imediatamente abaixo destes (Tucker \& Wright, 1990; Flügel, 2001). O ambiente de diagênese marinha é supersaturado na maioria dos minerais carbonáticos e em geral, causa extensa cimentação da porosidade (Morad, 1998). Portanto, tem baixo potencial para a formação de porosidade secundária por dissolução, exceto no ambiente marinho profundo onde a água se torna progressivamente insaturada (Morad, 1998). O modo como a diagênese atuará no ambiente marinho raso tem como um dos principais fatores a recarga e a taxa de fluxo da água marinha. Assim, a recarga pode ser constante e resultar em cimentação intensa (ex. recifes); estagnada e com pouca cimentação e micritização intensa (ex. lagunas); e pode ser do tipo vadosa (ex. praias e planícies de maré), onde o cimento se precipita pela evaporação da água do mar, sendo comum a associação com ocorrência de esteiras microbiais (Tucker \& Wright, 1990). Os principais cimentos da diagênese marinha são a aragonita e a calcita com alto teor de magnésio, já que a água do mar é saturada nos íons que formam essas fases minerais. $\mathrm{O}$ cimento de aragonita ocorre principalmente como cristais aciculares (agulhas) na formação de franjas isópacas em torno dos grãos ou como aglomerados de cristais desordenados no preenchimento de poros e como micrita. Em geral, os cimentos marinhos não são ferrosos e não apresentam luminescência por catodoluminescência (Tucker \& Wright, 1990).

O ambiente da diagênese meteórica pode ser subdivido em zona vadosa e zona freática. Ao contrário da composição da água marinha, a água meteórica apresenta baixa razão Mg/Ca (Flügel, 2001). A zona vadosa meteórica situa-se acima do nível freático e apresenta preenchimento dos poros por água e ar (zona de insaturação em água). É caracterizada por intensa dissolução dos minerais carbonáticos (aragonita e calcita com alto teor de magnésio são instáveis nestas condições), potencializada pela ocorrência de $\mathrm{CO}_{2}$ devido ao contato com atmosfera e solo. Na zona vadosa a água meteórica se concentra apenas no contato entre os grãos, por capilaridade, onde precipita cimento de calcita (com baixo teor de magnésio) em meniscos ou com geometria pendular, "pendurado" ao grão, pela ação gravitacional (Tucker \& Wright, 1990; Scholle \& Ulmer Scholle, 2003). Os cimentos de calcita são compostos por cristais finos devido à taxa de precipitação e as suas extremidades são mal desenvolvidas. A presença de silte vadoso (Scholle \& Ulmer Scholle, 2003) associado a estes cimentos é comum na zona vadosa e indica textura 
geopetal. Se houver presença de solos e raízes pode ocorrer formação de brechas, rizólitos (raízes calcificadas) e texturas alveolares de fragmentos envelopados que se formam pela movimentação e deformação dos solos, principalmente em substratos inclinados (Tucker \& Wright, 1990; Tucker \& Bathurst, 1990).

A zona freática meteórica caracteriza-se por apresentar poros completamente preenchidos por água (saturados em água). Devido à rápida taxa de fluxo da água meteórica e por apresentar-se mais saturada em íons carbonáticos (por enriquecimento durante fase de dissolução dos carbonatos em superfície pela diagênese meteórica vadosa) tem maior potencial para cimentação. Neste ambiente diagenético, o cimento de calcita é espático, em geral grosso a muito grosso (Tucker \& Wright, 1990), comumente blocoso, mas também granular ou em mosaico (Flügel, 2001) e apresenta baixo conteúdo de ferro. O cimento também pode ocorrer como franja de cristais de calcita espática (morfologia dente de cão) em torno de grãos. A transição de sedimentos carbonáticos em ambiente diagenético marinho para o meteórico (e vice-versa) é comum o que pode resultar na obliteração de texturas diagenéticas anteriores (ex. franja de calcita marinha obliterada por franja de calcita meteórica).

O ambiente de soterramento é caracterizado pela existência de fluidos que podem corresponder a misturas de águas meteórica e marinha ou a salmouras de composição química complexa que resultam da interação rocha-fluido a longo prazo, sob elevadas pressões e temperaturas (Morad, 1998). Os fluidos deste ambiente também podem originar-se de águas magmáticas e juvenis. A associação de texturas indicativas de compactação e dissolução por pressão (estilólitos e filmes de dissolução) e cimentos específicos, como calcita blocosa ou dolomita em sela enriquecidos com Fe e $\mathrm{Mn}$ e empobrecidos em Sr, podem indicar a atuação de processos por diagênese de soterramento (Flügel, 2001). Os fluidos de subsuperfície apresentam salinidades elevadas e por atuarem em ambiente redutor, podem incorporar, em cristais de calcita e dolomita, elementos como Mn e o Fe na forma reduzida (Flügel, 2001). A distinção entre cimentos de calcita gerados sob diagênese freática meteórica e os gerados em diagênese de soterramento pode ser difícil, já que apresentam morfologia e tamanhos semelhantes (blocosos). O estudo de inclusões fluidas, de isótopos de oxigênio, de catodoluminescência e de relações texturais de compactação podem auxiliar à responder esta questão (Tucker \& Wright, 1990). A dissolução de rochas carbonáticas no ambiente diagenético de soterramento pode ser atribuída a ocorrência de fluidos enriquecidos em $\mathrm{CO}_{2}$ formados pela descarboxilação térmica da matérica orgânica. Fluidos com elevada acidez também podem se originar por redução de sulfato. Tais fluidos corrosivos são formados provavelmente durante a 
compactação e maturação térmica de folhelhos ricos em matéria orgânica, portanto carbonatos que apresentam essas rochas nas vizinhanças podem apresentar porosidade gerada por dissolução (Tucker \& Wright, 1990).

A Figura 5 apresenta algumas ocorrências dos tipos de cimentos mais comuns, mas não exclusivos, de cada ambiente diagenético.

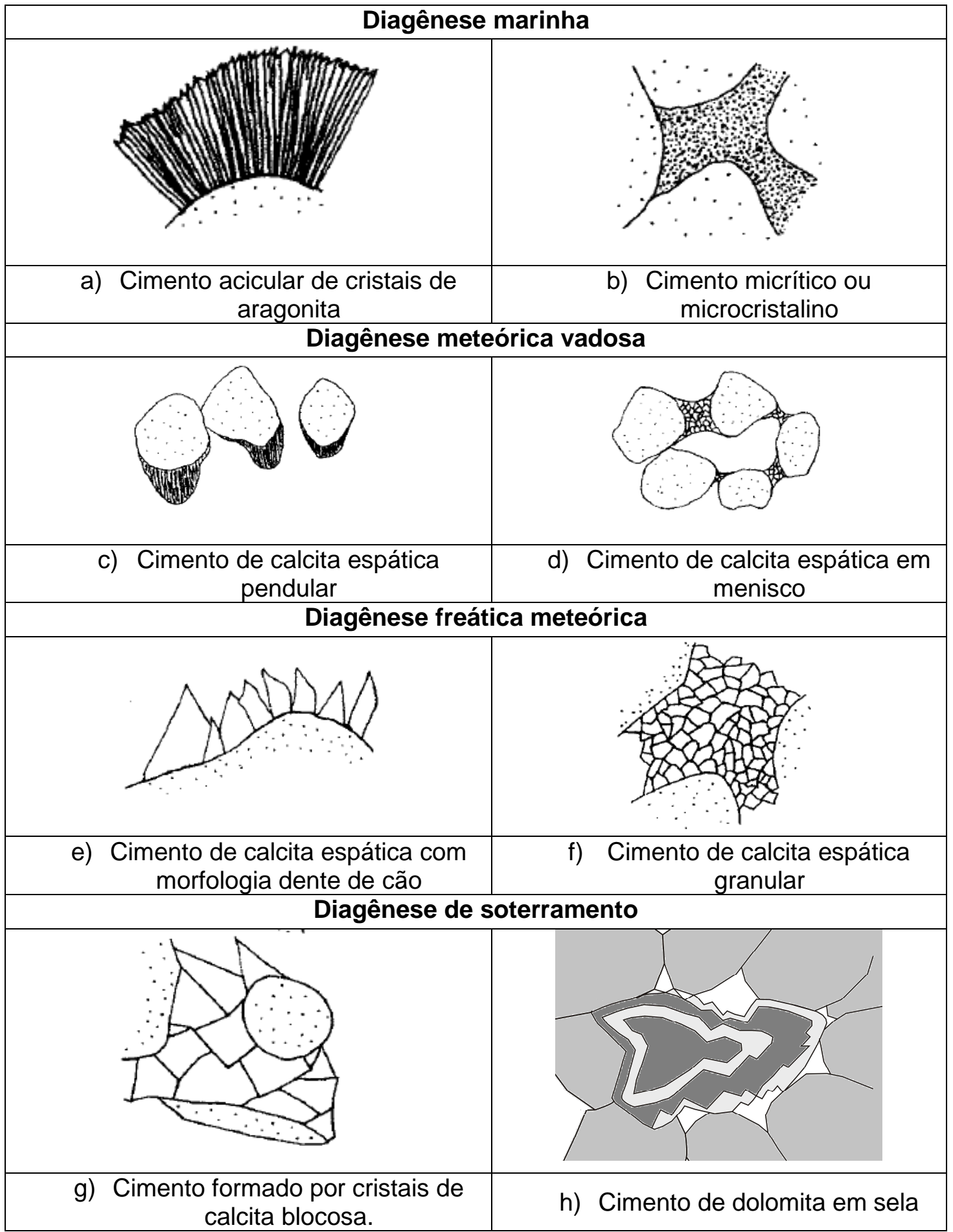

Figura 5. Exemplos de alguns tipos de cimentos de ocorrência comum (mas não exclusiva) de cada ambiente diagenético. Extraídos de Flügel (2001) (a, b, c, d, e, f, g) e modificado de Scholle \& Ulmer Scholle (2003) (h). 


\subsection{Fluidos hidrotermais - Definição, origem e paragêneses minerais em bacias sedimentares}

Fluidos hidrotermais podem ser definidos como fluidos mornos ou quentes (com aproximadamente 50 a $500^{\circ} \mathrm{C}$ ) que têm a capacidade de dissolver, transportar íons e precipitar minerais em resposta a mudanças nas condições físico-químicas (Pirajano, 2009). Os sistemas hidrotermais podem se formar abaixo dos oceanos (centros de espalhamento, ilhas vulcânicas e platôs oceânicos), em riftes intracontinentais (onde podem ocorrer com derrames vulcânicos), em margens continentais e em arcos magmáticos ao longo de zonas de subducção (Pirajano \& van Kranendonk, 2012). A água que compõe os fluidos hidrotermais pode ser de origem meteórica, conata, marinha, metamórfica, juvenil ou magmática (Pirajano, 2009). Os fluidos hidrotermais podem ser o resultado da mistura de diversas fontes de fluidos ou do predomínio de alguma delas. Quando a água subterrânea circula em regiões de gradientes geotérmicos elevados (por subida do manto ou área de ocorrência vulcânica), se aquece, e pode ocorrer ativação de um sistema hidrotermal meteórico que ao chegar à superfície por fraturas e falhas forma hot springs e geisers. Sistemas hidrotermais meteóricos em regiões de vulcanismo geralmente são aquecidos por magmas subjacentes e podem alcançar temperaturas de até $350^{\circ} \mathrm{C}$ (Pirajano, 2009). Sistemas hidrotermais também podem se formar pelo impacto de corpos celestes (Daubar \& Kring, 2001; Abramov \& Kring, 2004; Osinski et al., 2005). Neste caso, ocorre transformação da energia cinética em energia térmica e aumento do gradiente térmico pelo soerguimento da crosta.

A associação de certos tipos de ocorrências minerais, alguns elementos químicos e feições texturais podem ser indicativos da existência pretérita de sistemas hidrotermais em bacias sedimentares. Transformações químicas e minerais que requerem elevadas temperaturas para sua ocorrência, característicos de ambientes de soterramento, mas que independem do aumento da pressão (aumento da profundidade) para se formarem, também podem ter sua origem associada a fluidos hidrotermais. É o caso da dolomita em sela (saddle dolomite) ou dolomita barroca (baroque dolomite), cuja formação ocorre sob elevadas temperaturas a partir de fluidos hidrotermais ou por soterramento (Scholle \& Ulmer-Scholle, 2003). Radke \& Mathis (1980) associam a ocorrência da dolomita barroca com hidrocarbonetos e por isso sugere sua formação na janela de geração do óleo (entre 60 e $150^{\circ} \mathrm{C}$ ). A dolomita em sela pode ser reconhecida por apresentar faces curvadas e extinção ondulante (Radke \& Mathis, 1980; Scholle \& Ulmer-Scholle, 2003). A deformação dos retículos cristalinos se deve à frequente substituição de $\mathrm{Ca}$ ou $\mathrm{Mg}$ por Fe e outros cátions e alguns cristais podem apresentar-se zonados devido à pronunciada variação composicional (Tucker 
\& Wright, 1990). Quando a dolomita em sela é de substituição, pode apresentar aparência nebulosa devido à ocorrência de inclusões fluidas e vestígios de calcita reliquiar (Tucker \& Wright, 1990). Este tipo de dolomita pode ser reconhecido pelo método de catodoluminescência por apresentar elementos ativadores da luminescência como o $\mathrm{Pb}$ e Mn e supressores como o Fe (Morad, 1998). A dolomita em sela de origem hidrotermal ocorre comumente em associação com sulfetos, barita, fluorita e hidrocarbonetos (Scholle \& Ulmer-Scholle, 2003). A calcita blocosa é outro exemplo que pode estar associada à origem hidrotermal, apesar de sua ocorrência por si só não descartar outras origens (por soterramento e em zona freática meteórica, como já citado anteriormente). A calcita blocosa de origem hidrotermal pode incorporar os mesmos elementos químicos que a dolomita em sela, como o Fe o Mn, e assim ser reconhecida por catodoluminescência. A transformação de esmectita em ilita em associação com a ocorrência de outros paragêneses hidrotermais (ex. dolomita em sela e calcita blocosa), também pode indicar origem hidrotermal, uma vez que requer temperaturas elevadas para sua transformação, entre 100 e $250^{\circ} \mathrm{C}$ (McKinley et al., 2003). Outros métodos, como o de análise de inclusões fluidas, são muito importantes para corroborar a origem hidrotermal de paragêneses minerais de elevadas temperaturas. Também é muito comum que a passagem de fluidos hidrotermais em calcários resultem em feições típicas de dissolução (vugs e cavidades), fraturas e veios extensos que podem estar cimentados por minerais hidrotermais.

\subsection{Classificação de rochas carbonáticas}

As classificações de rochas carbonáticas existentes na literatura baseiam-se em critérios texturais e composicionais, sendo as de Dunham (1962), de Folk (1959) e de Folk (1962) as mais utilizadas. As classificações de Folk (1959) e Folk (1962) se baseiam principalmente na composição, enquanto a de Dunham (1962) na textura deposicional. A partir destas classificações, diversos outros autores propuseram modificações, sendo umas das mais importantes a de Embry \& Klovan (1971), que contribuiu para a complementação da classificação de Dunham (1962). Dentre estes complementos, Embry e Klovan (1971) adicionaram à classificação de Dunham (1962) os termos rudstone e floatstone para nomear grãos maiores que $2 \mathrm{~mm}$ e também detalharam a classificação de calcários autóctones. O presente trabalho seguiu a classificação de rochas carbonáticas proposta por Embry e Klovan (1971) (Figura 6). 


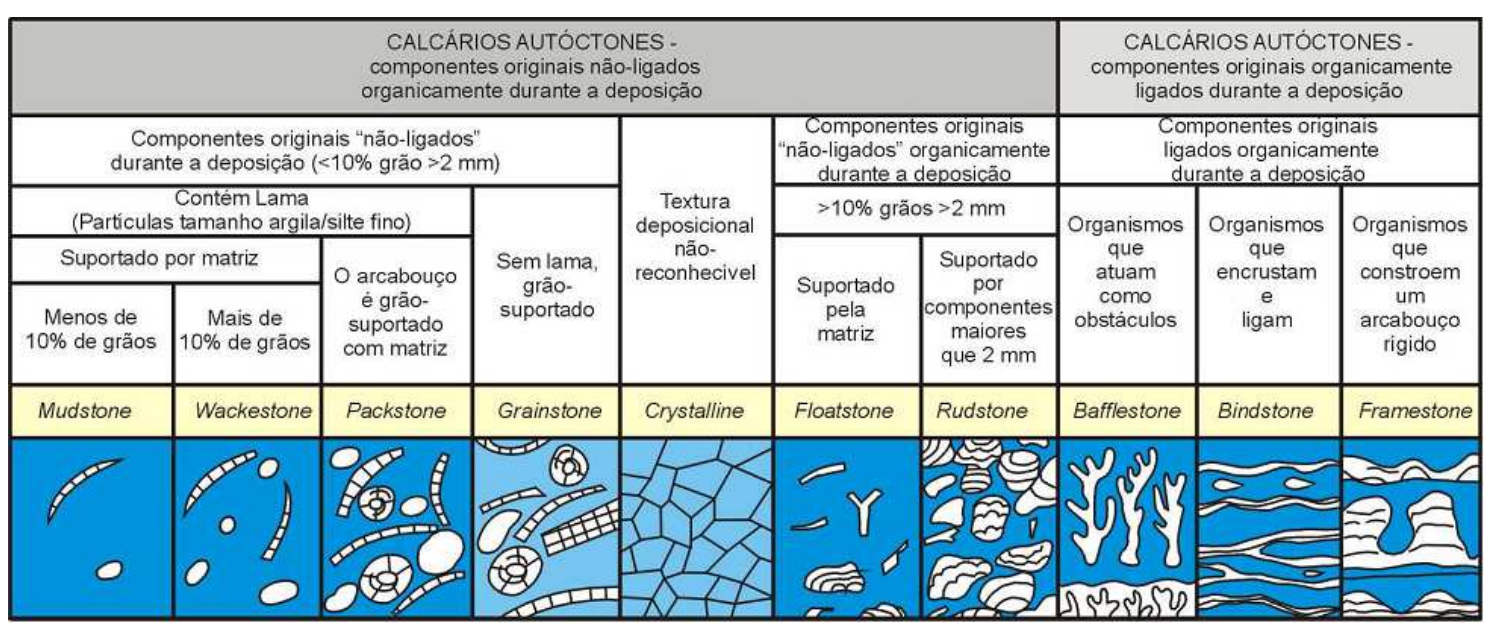

Figura 6. Classificação de rochas carbonáticas proposta por Embry \& Kovan (1971).

\subsection{Análise de inclusões fluidas aplicada ao estudo da diagênese}

A análise de inclusões fluidas tem sido utilizada de modo crescente no estudo de processos e ambientes diagenéticos (Goldstein \& Reynolds, 1994). As inclusões fluidas de minerais autigênicos fornecem informações sobre a composição dos fluidos diagenéticos e condições de pressão e temperatura de cristalização e deformação dos cimentos. Inclusões de hidrocarbonetos permitem ainda o estudo da geração e migração de petróleo (Munz, 2001; Coelho, 2004).

Quanto à origem, as inclusões fluidas podem ser classificadas como primárias, secundárias ou pseudo-secundárias. As primárias correspondem a fluidos aprisionados em cavidades geradas por irregularidades nas faces do cristal durante 0 seu crescimento. As secundárias ocorrem após a formação do cristal e se dispõem em trilhas (fraturas recristalizadas) que cortam os cristais. As pseudo-secundárias ocorrem como trilhas no interior do cristal e correspondem à recristalização de fraturas geradas durante o crescimento do cristal. Os principais fluidos aprisionados são os aquosos (com sais dissolvidos), $\mathrm{CO}_{2}, \mathrm{H}_{2} \mathrm{~S}, \mathrm{~N}_{2}$ e hidrocarbonetos. De modo geral, os fluidos são aprisionados como homogêneos, constituindo inclusões de fase única. Posteriormente, com o soerguimento e resfriamento ocorre o aparecimento de uma bolha de gás ou vapor nas inclusões. No caso de soluções aquosas muito salinas, saturadas, são formados minerais de saturação (minerais filhos). Como discute Sorby (1858) 0 aparecimento da bolha ocorre com o resfriamento devido à contração diferencial entre o cristal hospedeiro e o fluido aprisionado, de forma que com a contração mais elevada do fluido em relação ao cristal, uma bolha de gás ou vapor tenderá a se desenvolver. Deste modo, com o resfriamento, as inclusões monofásicas aprisionadas a partir de um sistema homogêneo de fluidos, podem se tornar bifásicas (liquido + 
vapor), trifásicas (líquido + vapor + sólido de saturação), multifásicas (líquido 1 + líquido 2 + gás + sólido) ou constituir outras combinações contendo dois ou mais sólidos. Sorby (1858) foi o primeiro pesquisador a propor o uso das inclusões fluidas como potencial geotermômetro. Como as bolhas aparecem com o resfriamento, este autor mostrou que o reaquecimento das inclusões, no laboratório, até sua completa homogeneização (uma fase) fornece as temperaturas mínimas de aprisionamento do fluido, quando as inclusões foram formadas a partir de um sistema homogêneo. Muitas vezes as inclusões podem ser formadas a partir de fluidos já imiscíveis, por exemplo, em zonas de alívio de pressão, e, nesses casos, podem ser obtidas as temperaturas reais de aprisionamento e formação do mineral hospedeiro (Roedder, 1984; Shepherd et al. 1985).

Para inclusões cogenéticas e cujo aprisionamento ocorreu a partir de um sistema homogêneo, a análise da razão volumétrica entre fases líquida e vapor fornece informações sobre as condições de aprisionamento dos fluidos. Isto permite identificar inclusões aprisionadas na zona saturada de baixas temperaturas $\left(<50^{\circ}\right)$ de inclusões aprisionadas em altas temperaturas $\left(>50^{\circ}\right)$. Nas condições de menor temperatura, as inclusões apresentam-se monofásicas ou com razão líquido/vapor variável, enquanto que as segundas apresentam-se pelo menos bifásicas (líquido+vapor) e com razões líquido/vapor aproximadamente uniforme (Goldstein \& Reynolds, 1994).

Casos particulares como inclusões fluidas que tiveram suas densidades alteradas por processo de necking down (estrangulamento) podem ser reconhecidas na petrografia. O necking down ocorre após o aprisionamento das inclusões provocando sua subdivisão. Quando ocorre após a formação da bolha de vapor causa a mudança nas proporções vapor/líquido nas novas inclusões geradas, as quais passam a fornecer densidades distintas entre si e com a do fluido original (Figura 7). Inclusões submetidas a estrangulamento devem ser desconsideradas para medidas microtermométricas, uma vez que possuem características distintas das originais. 


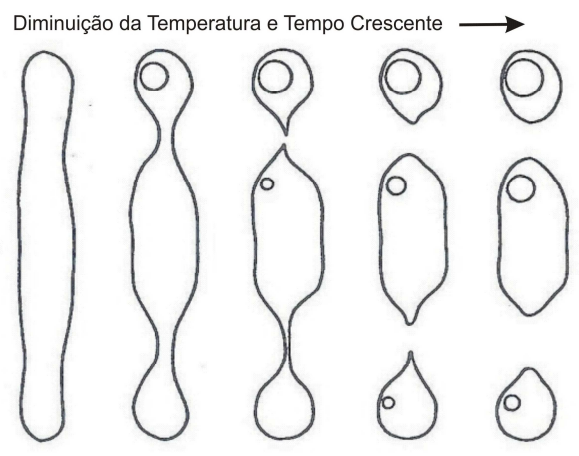

Figura 7. Exemplo da evolução do processo de necking down em uma inclusão fluida. Extraído de Roedder (1984). Observa-se que a subdivisão ocorre em diferentes temperaturas. Ao final do processo, como as três inclusões apresentam proporções distintas do volume da fase vapor, os dados fornecem valores de densidades diferentes entre si e em relação à original. Assim, quando a amostra é aquecida, as três inclusões formadas homogeneízam em diferentes temperaturas, nenhuma representativa da temperatura de homogeneização real.

A petrografia de inclusões também permite determinar a ocorrência de recristalização devido à deformação. Neste caso, as inclusões fluidas (inclusões secundárias) comumente se dispõem em alinhamentos gerados pela cicatrização de fraturas. As inclusões secundárias fornecem informações mais representativas da época das condições de deformação que da precipitação primária de cimentos (Goldstein, 1993).

Inclusões fluidas em cristais de calcita são sensíveis a reequilíbrios quando submetidas a temperaturas mais elevadas que as de aprisionamento devido à maior facilidade de ocorrer estiramento (stretching) (Prezbindowski \& Larese, 1987; Goldstein \& Reynolds, 1994). O reequilíbrio ocorre quando a inclusão muda de volume (stretching) sem, ou insignificante, perda de fluido; ou quando perde ou ganha componentes (leakage ou decrepitação parcial). Um dos casos mais comuns de reequilíbrio é quando as inclusões fluidas são submetidas a aquecimento por soterramento e sofrem aumento de seu volume devido aumento relativo da pressão interna do fluido aprisionado e conseqüente dilatação inelástica do mineral (stretching). Isto leva ao aumento das temperaturas de homogeneização em inclusões bifásicas (Goldstein \& Reynolds, 1994).

A análise das inclusões fluidas sob luz ultravioleta (UV) permite 0 reconhecimento de inclusões de hidrocarbonetos, uma vez que estas, comumente, tornam-se fluorescentes nestas condições. A cor de fluorescência está relacionada com o grau de maturidade do hidrocarboneto (grau API) e pode variar do vermelho ao azul. Em ordem crescente de grau API, tem-se a seguinte seqüência: vermelho, laranja, amarelo, verde e azul. Quanto mais próximo do vermelho mais pesado é o 
hidrocarboneto. No entanto, inclusões gasosas de hidrocarbonetos leves, como metano $\left(\mathrm{CH}_{4}\right)$, não apresentam fluorescência. Além disso, inclusões de hidrocarbonetos com predominância da fase gasosa também são de difícil detecção devido à cor (geralmente azul escuro) e à baixa intensidade da fluorescência. Hidrocarbonetos com baixo grau API e ricos em asfaltenos e compostos NSO (nitrogênio-sulfeto-oxigênio) também apresentam fluorescência com baixa intensidade em cores que variam de amarelo a laranja avermelhado (Burrus, 2003). Técnicas de espectrometria e cromatografia permitem a discriminação dos componentes químicos de modo mais detalhado. A espectrometria Raman possibilita a identificação de compostos moleculares líquidos, sólidos e gasosos. Entre os hidrocarbonetos, a espectrometria Raman permite apenas o reconhecimento seguro do metano. Para identificação dos hidrocarbonetos mais pesados devem ser utilizados métodos de cromatografia gasosa ou a espectrometria de massa (Munz, 2001).

\subsubsection{Comportamento de inclusões fluidas aquo(salinas) em ambientes} diagenéticos de diferentes pressões e temperaturas

A interpretação termobarométrica das inclusões fluidas é realizada com base nas relações de fase, equações de estado e curvas de equilíbrio de sistemas estudados experimentalmente e que tenham as variáveis, tais como, pressão, volume, temperatura e composição conhecidos. Sabendo-se a composição do sistema, essas relações podem ser vistas em diagramas tridimensionais que relacionam pressão, volume e temperatura. Costuma-se trabalhar com diagramas bidimensionais do tipo Pressão $(\mathrm{P})$ x Temperatura $(\mathrm{T})$ e Temperatura $(\mathrm{T}) \times$ Volume $(\mathrm{V})$ (ou densidade) para maior facilidade (Roedder,1984).

De acordo com Goldstein \& Reynolds (1994), na maioria das condições de pressão e temperatura reinantes nos ambientes diagenéticos (entre o gradiente hidrostático e o litostático), os fluidos aquosos presentes nos poros ocorrem sempre no campo de estabilidade da fase líquida, uma vez que se encontram acima da curva de equilíbrio líquido-vapor para um sistema aquoso com maior ou menor salinidade, como pode ser visto na seção P-T do diagrama para esse sistema com água pura (Goldstein \& Reynolds, 1994) (Figura 8). As discussões apresentadas por esses autores a respeito deste diagrama serão apresentados, a seguir, para ilustrar o comportamento típico de uma inclusão aquosa aprisionada no ambiente diagenético. Assim, considere que no ponto A ocorre a precipitação de um mineral diagenético que aprisiona fluidos aquosos presentes nos poros da rocha soterrada. Nas condições P-T 
do ponto $A$, os fluidos situam-se acima da curva de equilíbrio líquido (L) - vapor (V) para o sistema aquoso e, portanto, as inclusões aprisionadas serão monofásicas constituídas apenas por $\mathrm{H}_{2} \mathrm{O}$ líquida.

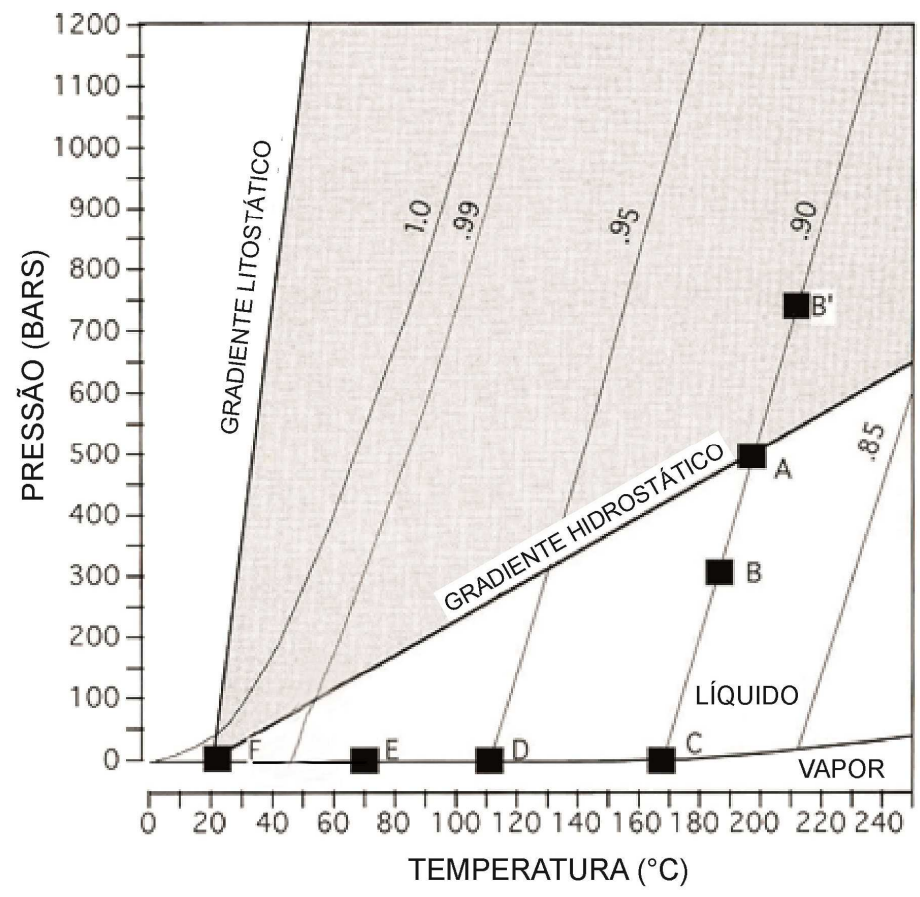

Figura 8. Diagrama P-T para o sistema aquoso com apresentação das condições reinantes no ambiente diagenético. Visualiza-se o comportamento de uma inclusão aprisionada em A, no interior de um cristal diagenético, sob condições de resfriamento e soerguimento progressivos, com passagem pela curva de equilíbrio líquido (L) vapor (V), até alcançar a T ambiente. Também é apresentando o comportamento da inclusão aprisionada em A (no interior de um cristal diagenético), que sofre soterramento até B', e passará, posteriormente, por condições de resfriamento até alcançar a temperatura ambiente. Modificado de Goldstein \& Reynolds (1994).

Com o soerguimento até a temperatura ambiente, o fluido dentro da inclusão terá suas condições de P e T modificadas segundo uma isócora (linha de volume ou densidade constante), desde que não tenham sofrido modificações em seus volumes (densidades) desde seu aprisionamento. Essa é uma das premissas básicas para a validade das análises microtermométricas (Roedder, 1984; Shepherd et al., 1985 e Goldstein \& Reynolds, 1994). No exemplo de Goldstein \& Reynolds (1994), o fluido aprisionado possui densidade de $0,90 \mathrm{~g} / \mathrm{cm}^{3}$, representada pela isócora A-C. Assim, enquanto a inclusão sofre um decréscimo de $T$ e $P$ segundo a isócora $A-C$, o mineral segue o gradiente hidrostático do ambiente, conforme o soerguimento avança. No ponto $\mathrm{C}$, a curva de equilíbrio líquido-vapor é atingida e assim, deveria aparecer uma minúscula bolha de vapor na inclusão, o que nem sempre ocorre, devido à metaestabilidade. Neste caso, a fase constituída apenas por líquido pode persistir até temperaturas mais baixas. A inclusão segue as condições $P$ e $T$ da curva $L-V$ com 0 
contínuo resfriamento, mas a proporção da fase vapor em relação à fase líquida vai aumentando progressivamente enquanto a pressão interna decresce gradualmente. Quando a inclusão atinge a temperatura ambiente, no ponto $F$, o diagrama para 0 sistema aquoso indica que sua pressão interna é muito baixa, próxima ao vácuo. Esse diagrama também indica que durante a maior parte da história do resfriamento, a pressão interna das inclusões é bem mais baixa que a pressão dos fluidos dos poros circundantes, a qual se desloca ao longo do gradiente termobárico considerado. Contudo, se o soterramento continuar após o aprisionamento dos fluidos nos cristas diagenéticos então formados, a pressão interna das inclusões será maior que a $P$ externa. Se o mineral hospedeiro da inclusão possui dureza baixa, por exemplo, a sobrepressão no interior das inclusões podem causar o reequilíbrio das inclusões por expansão irreversível decorrente de deformação plástica, o que resulta no aumento do volume das cavidades (stretching), ou escape dos fluidos anteriormente existentes e repreenchimento com novas soluções presentes no ambiente.

\subsubsection{Características das inclusões fluidas aprisionadas em ambientes} diagenéticos de baixa e alta temperatura e suas modificações devido à reequilíbrios posteriores

Este tópico apresenta as principais características de associações de inclusões fluidas aprisionadas em zona saturada de baixa e alta temperatura, e suas modificações resultantes de reequilíbrios posteriores devido ao aumento de temperatura e/ou pressão (soterramento ou hidrotermalismo), de acordo com Goldstein \& Reynolds (1994).

\section{A) Zona saturada de baixa temperatura $\left(<50^{\circ} \mathrm{C}\right)$}

Esta zona está situada abaixo do nível freático e o ambiente de aprisionamento é dominado, principalmente, por soluções aquosas com uma única fase líquida, como discutido no diagrama P-T (Figura 6) para o sistema aquoso apresentado anteriormente. Contudo, também podem ocorrer pequenas quantidades de gases. Se não houver soterramento ou reequilíbrio térmico, as inclusões fluidas aquosas se apresentarão monofásicas liquidas à temperatura ambiente (Figura 9A). Com o aquecimento devido ao soterramento ou à anomalia térmica (ex. hidrotermalismo) algumas ou todas as inclusões fluidas poderão sofrer reequilíbrios térmicos por estiramento (stretching). Se apenas algumas inclusões sofrerem reequilíbrios, o resultado à temperatura ambiente será a co-existência de inclusões fluidas 
monofásicas e bifásicas (Figura 9B). Neste caso, as associações de inclusões bifásicas apresentarão razão entre as fases vapor (V) e líquida (L) relativamente semelhantes, embora as dimensões da fase vapor possam variar desde muito pequenas até cerca de $15 \%$ do volume da inclusão, devido à variação do comportamento das inclusões diante do reequilíbrio. Porém, se o aquecimento ocorrer sob temperaturas mais elevadas, todas as inclusões fluidas sofrerão reequilíbrio por estiramento e à temperatura ambiente todas serão bifásicas (Figura 9C). Neste caso, as associações de inclusões bifásicas apresentarão certa diferença na razão dos volumes da fase líquida $(L)$ e vapor $(V)$, ou do volume da fase vapor ( $\left.V_{V A P}\right)$ e do volume da inclusão fluida $\left(\mathrm{V}_{\mathrm{IF}}\right)$, em comparação com o caso anterior, mas ainda assim serão relativamente semelhantes. Em ensaios com a platina de esmagamento, as inclusões reequilibradas apresentam colapso da bolha (pressão próxima ao vácuo), no caso das inclusões aquosas, ou a expansão das bolhas, o que seria indicativo da presença de gases sob pressão, como, por exemplo, $\mathrm{CH}_{4}$. A associação de inclusões fluidas desta zona pode ser diferenciada daquelas que apresentam co-existência de inclusões monofásicas e bifásicas resultantes da deformação por estrangulamento (necking down), pois não apresentam grande variação nas razões entre as fases líquida e vapor.

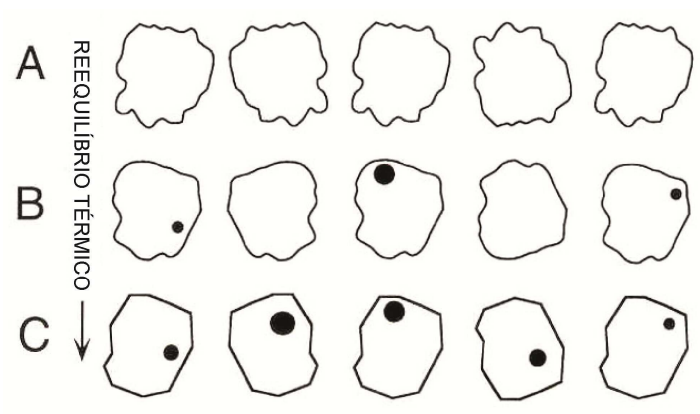

Figura 9. Características das inclusões fluidas aprisionadas em ambientes diagenéticos de baixa temperatura e suas modificações ( $A, B$ e $C$ ) devido à reequilíbrios posteriores. Modificado de Goldstein \& Reynolds (1994).

\section{B) Zona saturada de alta temperatura $\left(>50^{\circ} \mathrm{C}\right)$}

A zona saturada com temperaturas acima de $50^{\circ} \mathrm{C}$ ocorre em intervalos estratigráficos que sofreram soterramento significativo. $\mathrm{O}$ ambiente de aprisionamento dos fluidos diagenéticos é dominado por soluções aquosas constituídas por única fase líquida, embora também possam existir sistemas imiscíveis. Com o soerguimento e resfriamento, todas as inclusões fluidas apresentarão bolhas de vapor com volume inferior a $15 \%$ do volume da inclusão à temperatura ambiente (Figura 10A). Estas inclusões apresentam razões $\mathrm{V}_{\mathrm{VAP}} / \mathrm{V}_{\mathrm{IF}}$, semelhantes, sendo essa feição característica 
da diagênese em temperatura elevada. Com os ensaios de esmagamento, verifica-se que a pressão nas bolhas deve ser próxima ao vácuo (colapso) ou mais alta (expansão das bolhas), neste caso, dependendo do conteúdo de gás no fluido. Com o aquecimento devido ao soterramento ou anomalia térmica (hidrotermalismo), as inclusões fluidas à temperatura ambiente serão todas bifásicas e muitas apresentarão bolhas maiores, devido a reequilíbrios por stretching (Figura 10B). Portanto, terão maior razão $\mathrm{V}_{\mathrm{VAP}} / \mathrm{V}_{\mathrm{IF}}$ comparado ao caso em que não tivessem sido reequilibradas. Como o reequilíbrio afeta cada inclusão de modo diferente, pode haver diferenças nas razões entre as fases líquida e vapor das inclusões. Como resultado, durante o aquecimento, serão obtidos dados com certa variação das temperaturas de homogeneização. Da mesma forma que o caso anterior, as pressões nas bolhas também devem ser próximas ao vácuo ou mais elevadas.

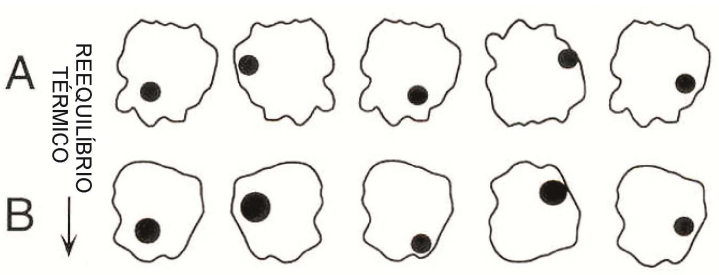

Figura 10. Características das inclusões fluidas aprisionadas em ambientes diagenéticos de alta temperatura e suas modificações $(A, B$ e $C)$ devido à reequilíbrios posteriores. Modificado de Goldstein \& Reynolds (1994).

\section{RESULTADOS}

\subsection{Descrição dos afloramentos}

Este item enfatiza a descrição dos afloramentos das formações Corumbataí e Teresina no centro-leste (Ipeúna) e centro-sul (Fartura e Taguaí) do Estado de São Paulo e no norte do Estado do Paraná (Jacarezinho, Santo Antonio da Platina e Joaquim Távora), onde foram coletadas amostras para estudos petrográficos e de inclusões fluidas.

Em Ipeúna (SP), foi visitado afloramento da Formação Corumbataí situado à margem do Rio Passa Cinco (afloramento MS-1, ponto 15 na Figura 2). Este afloramento é formado por siltitos roxo-acinzentados laminados, com veios de quartzo e calcita. Os veios de quartzo são subverticais e apresentam espessura centimétrica, enquanto que os veios de calcita são sub-horizontais e com espessura milimétrica a centimétrica. Os veios de calcita horizontais apresentam textura fibrosa e formam dobras abertas de amplitude decimétrica a métrica. 
Na porção superior da Formação Teresina em Anhembi (SP), foram visitados afloramentos de estruturas cônicas silicosas, de altura média entre 0,5 a 1,5m, sobre fácies de siltitos com laminação heterolítica de cor bege esverdeado a marrom avermelhado e calcários silicificados. Esses cones silicosos apresentam núcleos com geodos de cristais de quartzo (afloramentos IP-24, IP-25, IP-22 e IP-23, respectivamente pontos 11, 12, 13 e 14 na Figura 2). Esses cones ocorrem concentrados nesta região, em área menor que $1,5 \mathrm{~km}^{2}$ (Yamamoto et al., 2005).

Entre os municípios de Fartura e Taguaí (SP) foram estudados seis afloramentos da Formação Teresina e rochas associadas (afloramentos JZ-15, JZ-16, IP-06, IP-32, IP-37 e IP-39, respectivamente pontos de 1 a 6 na Figura 2). As principais fácies da Formação Teresina observadas nesses afloramentos foram: a) Packstone/grainstone oolítico, parcialmente silicificado, maciço ou com estratificações cruzadas, com níveis brechados, e podem apresentar intraclastos. Esta fácies apresenta nódulos de calcedônia associados a veios de calcedônia e calcita de diversas direções, os quais apresentam espessura milimétrica a centimétrica e extensão centimétrica. Esses veios, por vezes, terminam em cavidades de dissolução; b) Rudstone bioclástico composto principalmente por conchas de bivalves; c) Chert bandado, que ocorre intercalado a fácies de siltito arenoso/argiloso com laminação heterolítica; d) Siltito arenoso/argiloso com laminação heterolítica, por vezes associado a gretas de contração. Veios horizontais de calcita fibrosa ocorrem na fácies siltito com laminação heterolítica; e) Arenito muito fino siltoso. Além das fácies descritas, a região de Fartura e Taguaí também inclui diversos afloramentos de diques básicos (afloramento JZ-16, ponto 2 na Figura 2), com espessura de metros a dezenas de metros e fraturas verticais preenchidas por calcita.

No norte do Estado do Paraná, entre os municípios de Jacarezinho e Joaquim Távora, a Formação Teresina é composta pela alternância entre fácies carbonáticas e terrígenas, principalmente na sua porção superior. Esta assembléia litológica é semelhante à observada na Formação Teresina na região de Fartura e Taguaí. As principais fácies observadas nesta região foram (afloramentos JZ-02, JZ-03, JZ-04, JZ05, JZ-07, JZ-10 e JZ-13, respectivamente pontos de 1 a 7 na Figura 3): a) Chert nodular brechado, com ocorrência de intraclasto de wackestone bioclástico silicificado com cristais romboédricos de dolomita com zoneamento. Ocorre associado a camadas adjacentes que apresentam estruturas de fluidificação; b) Packstone/grainstone oolítico com bioclastos de bivalves; c) Grainstone peloidal; d) Dolomito com laminações onduladas formadas por cristais euédricos de dolomita; e) Marga parcialmente silicificada com níveis de nódulos de calcedônia deformados e níveis de 
sedimentos terrígenos com grãos angulosos de quartzo. Também pode apresentar fragmentos fosfáticos de ossos e escamas de peixes. Esta fácies está associada à fácies de dolomito com laminações onduladas formadas por cristais de dolomita; f) Microbialito silicificado com níveis terrígenos. Ocorre associado à fácies chert nodular brechado; g) Mudstone parcialmente silicificado com níveis terrígenos compostos principalmente por grãos angulosos de quartzo, com alguns níveis de nódulos de calcedônia.

Os afloramentos da Formação Teresina estudados na região próxima ao limite entre os estados de São Paulo (Taguaí e Fartura) e Paraná (Joaquim Távora, Santo Antonio da Platina e Jacarezinho) destacam-se pela elevada ocorrência de corpos ígneos intrusivos (diques e sils).

A Figura 11 apresenta seção colunar representativa das fácies terrígenas e carbonáticas da Formação Teresina na região de Taguaí e Fartura (SP). Esta assembléia de fácies é considerada representativa do topo da Formação Teresina nas áreas estudadas. 


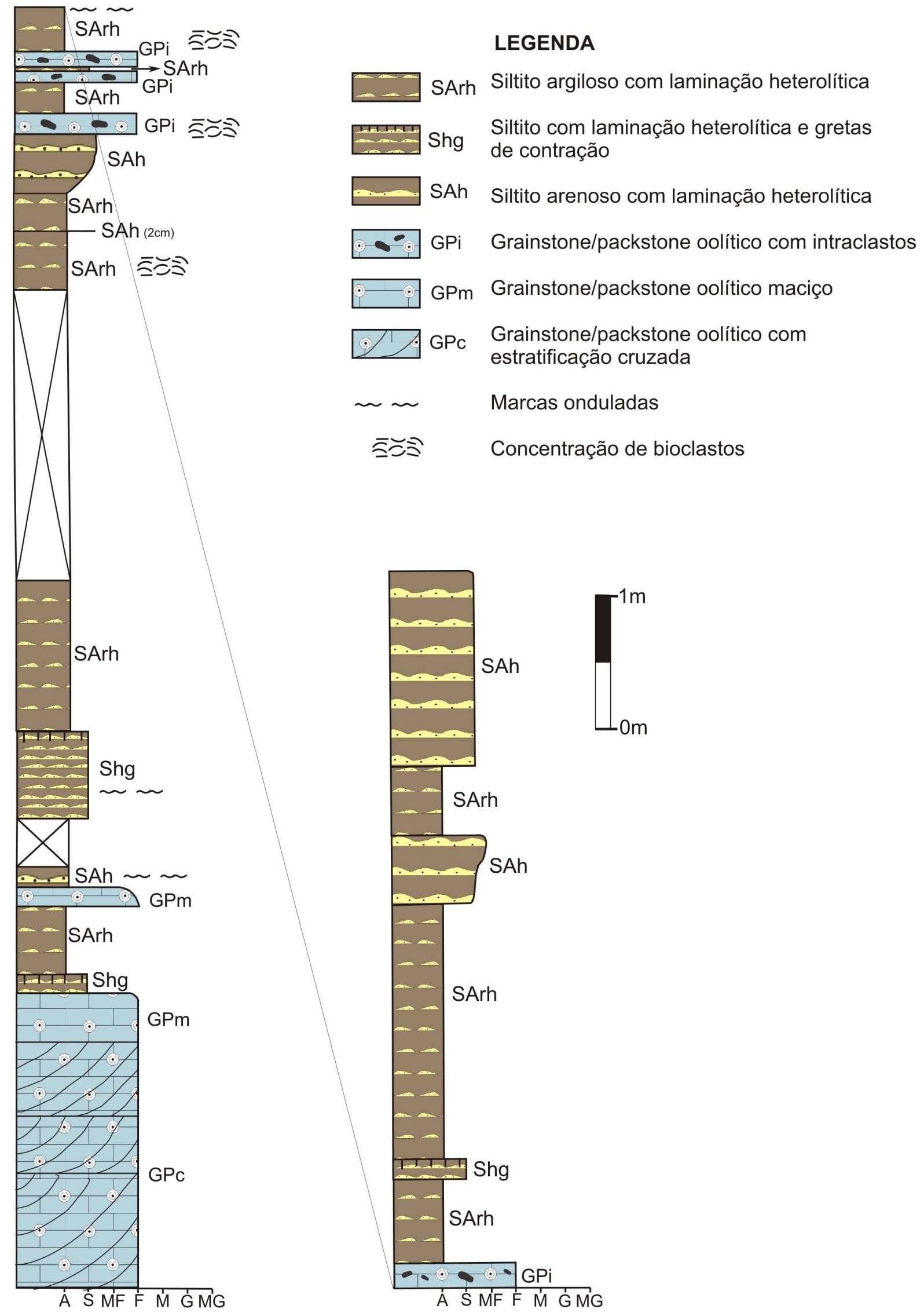

Figura 11. Seção colunar representativa das fácies descritas no topo da Formação Teresina (Mineração de Calcário Irmãos Gobbo - Taguaí, SP). 
A Figura 12 apresenta fotografias panorâmicas dos principais afloramentos visitados no centro-leste (Ipeúna/Anhembi) e centro-sul (Taguaí/Fartura) do Estado de São Paulo e no norte do Estado do Paraná (Jacarezinho/Joaquim Távora).
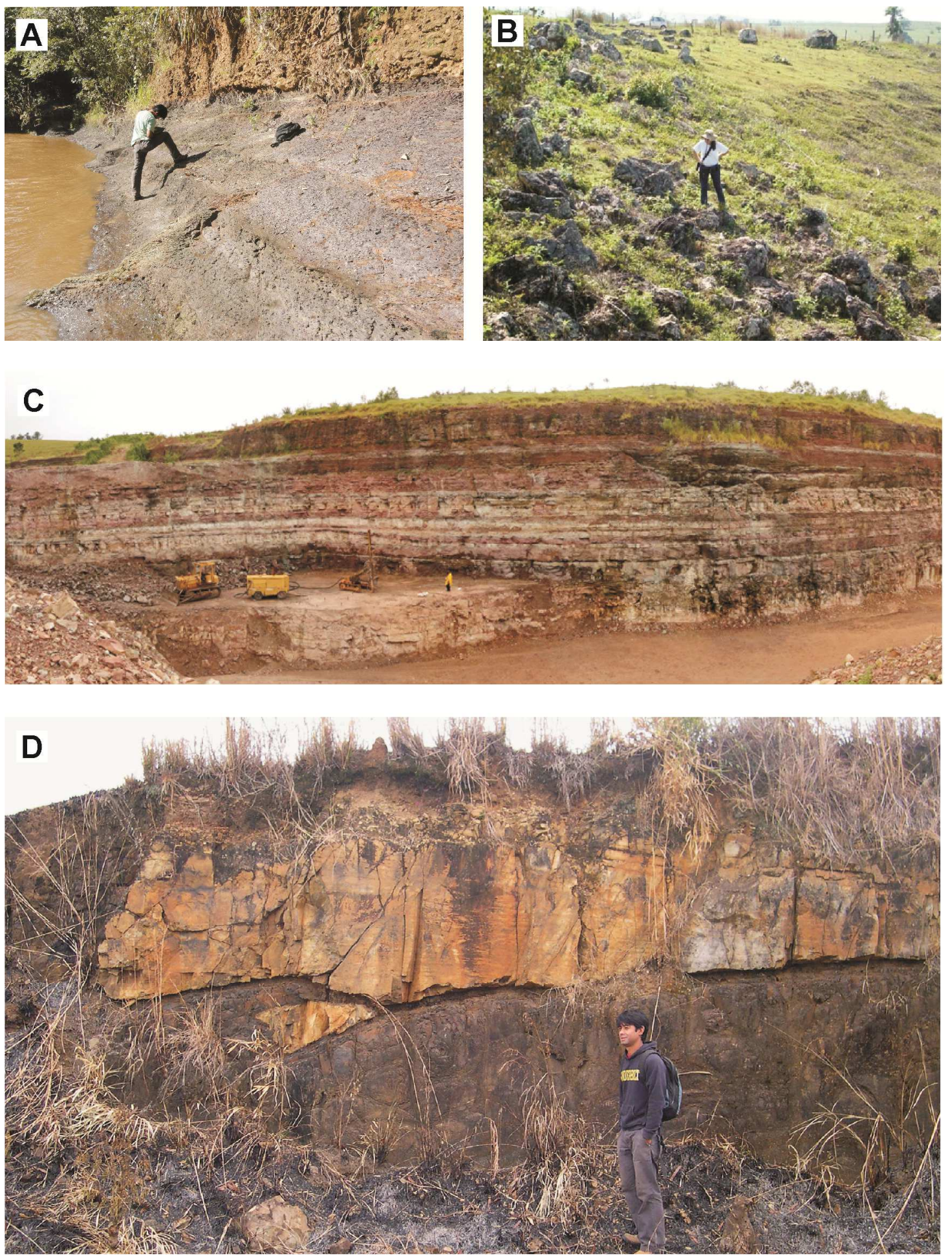

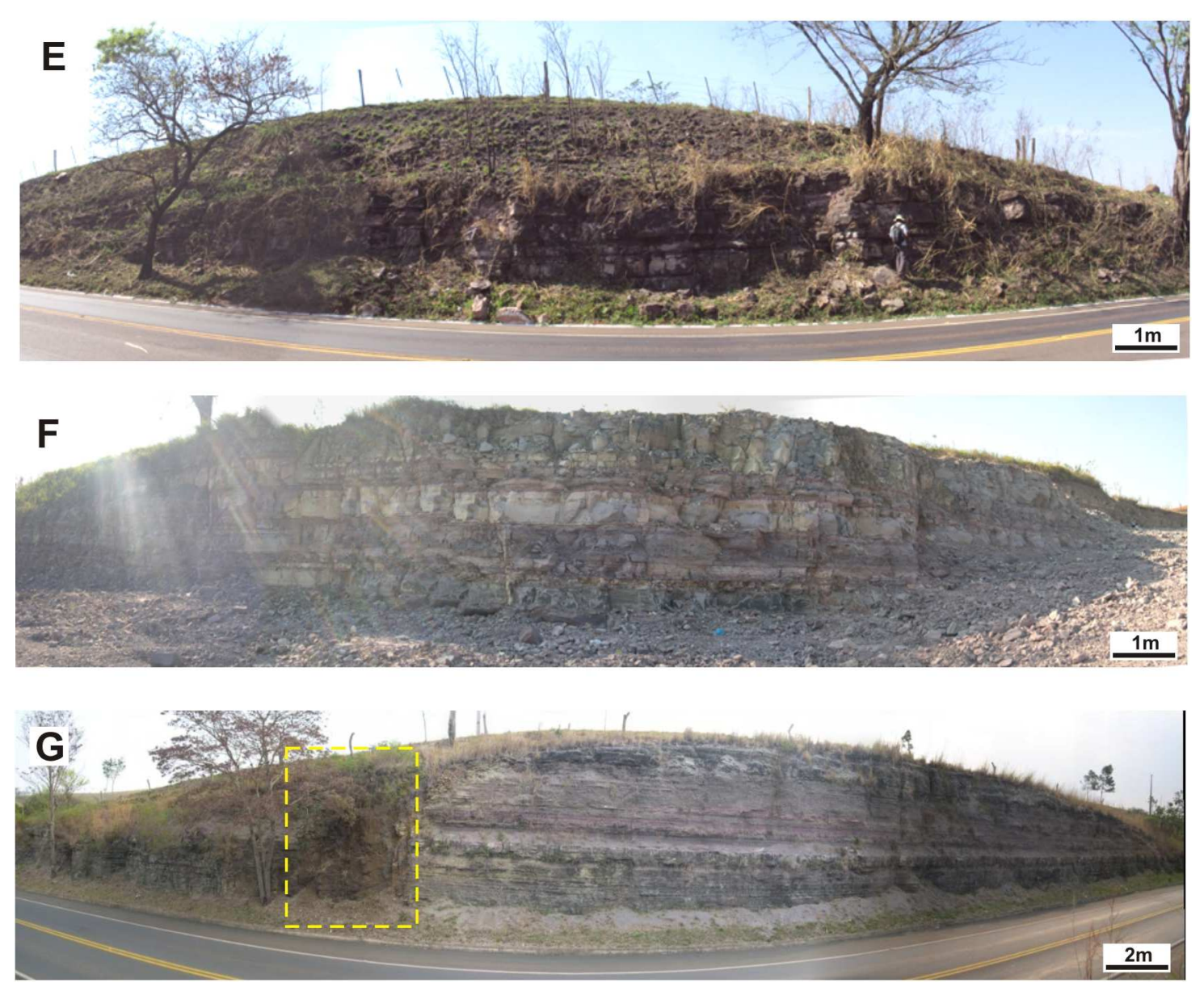

Figura 12. A) Siltitos roxo-acinzentados laminados da Formação Corumbataí ao longo da margem esquerda do rio Passa Cinco (afloramento MS-1, Ipeúna, SP). B) Cones silicosos sobre siltitos e calcários silicificados da Formação Teresina (afloramento IP22, Anhembi, SP). C) Alternância entre fácies terrígenas e carbonáticas na frente de lavra da Mineração de Calcário Irmãos Gobbo (afloramento IP-06, Taguaí, SP). D) Contato entre siltito arenoso da Formação Teresina e dique básico associado ao magmatismo Serra Geral (afloramento JZ-16, Fartura, SP). E e F) Calcários silicificados da Formação Teresina, Jacarezinho, PR. Afloramentos JZ-02 e JZ-05, respectivamente; G) Dique básico alterado (tracejado amarelo) corta calcários da Formação Teresina (afloramento JZ-10, Joaquim Távora, PR).

\subsection{Aspectos Estruturais}

Nas regiões de estudo, as formações Teresina e Corumbataí são dominadas por estruturas de deformação rúptil. Os afloramentos estudados apresentam alta freqüência de fraturas subverticais e com espaçamento decimétrico a métrico. A região que abrange os municípios compreendidos no limite entre os estados de São Paulo e Paraná (Taguaí e Fartura, SP, e Jacarezinho, Santo Antonio da Platina e Joaquim Távora, PR) destaca-se pela elevada quantidade de diques de direção NW, principalmente de rochas ígneas básicas, que podem atingir quilômetros de extensão e dezenas de metros de espessura (figuras 2 e 3). As direções das fraturas foram apresentadas na forma de diagramas em rosetas (Figura 13). As fraturas foram 


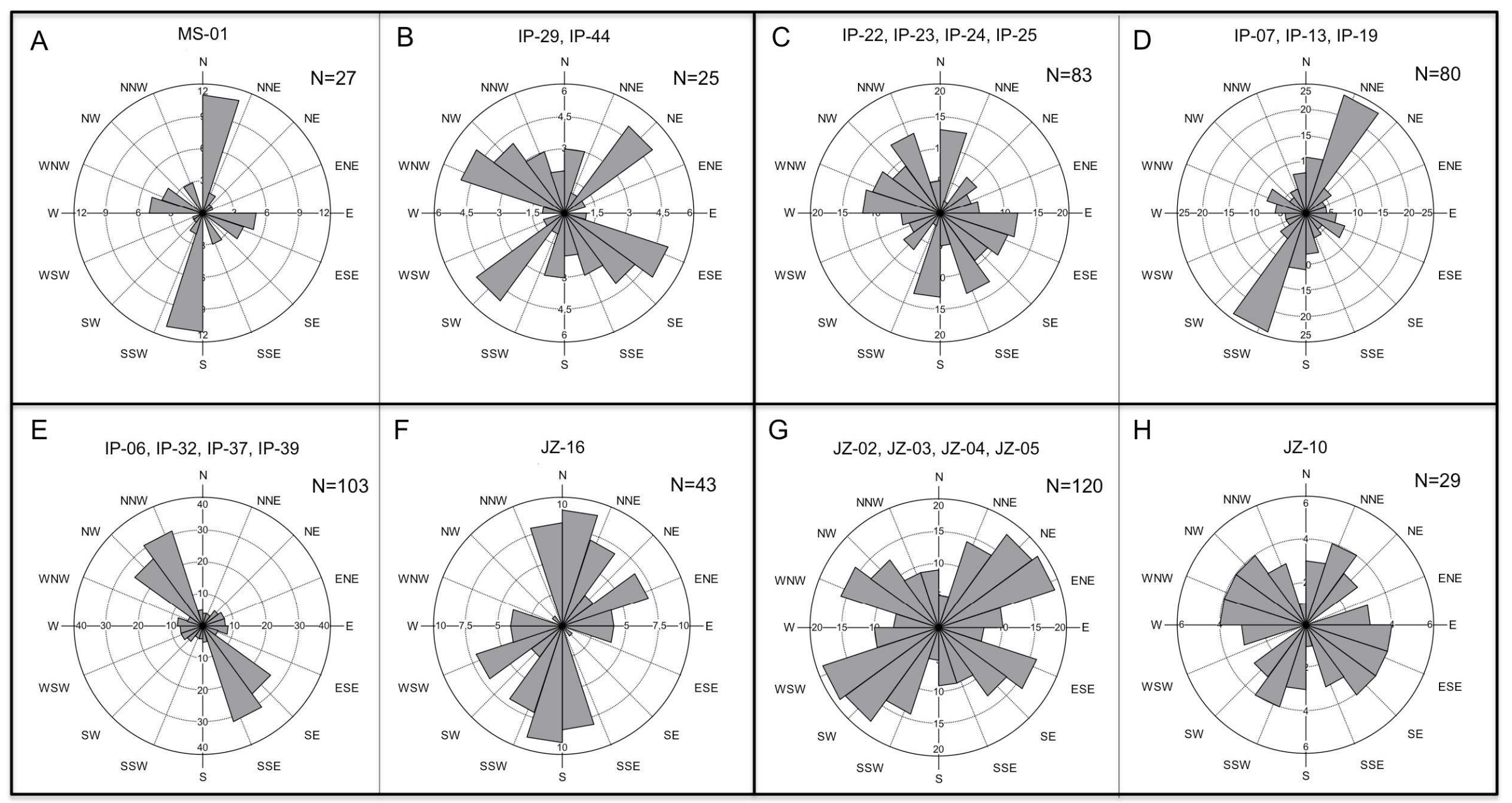

Figura 13. Direções de fraturas medidas nos afloramentos estudados. A) Ipeúna (SP); B) Rio Claro (SP); C) Anhembi (SP); D) PorangabaGuareí (SP); E e F) Taguaí-Fartura (SP); G) Jacarezinho (PR); H) Joaquim Távora (PR). A e B correspondem a medidas de fraturas em afloramentos da Formação Corumbataí e C, D, E, G e H em afloramentos da Formação Teresina. $F$ corresponde à fraturas em dique de rocha ígnea básica. 
agrupadas de acordo com as regiões (Ipeúna, Ipeúna-Rio Claro, Anhembi, PorangabaGuareí, Taguaí-Fartura (SP), Jacarezinho e Joaquim Távora (PR)) e unidades estudadas (Teresina, Corumbataí ou Serra Geral).

Em geral, as formações Teresina e Corumbataí em todas as regiões estudadas apresentam fraturas com direções em dois trends principais, um NNW a WNW e outro NNE a NE. As fraturas de direção NNE a NE predominam nas regiões de Ipeúna e Porangaba-Guareí e no dique básico associado ao magmatismo Serra Geral na região de Fartura. As fraturas de direção NNW a WNW se destacam principalmente na Formação Teresina na região de Taguaí-Fartura. Nas outras localidades esses dois trends estão distribuídos de maneira relativamente semelhante.

\subsection{Minerais autigênicos}

\subsubsection{Componentes silicosos (quartzo e calcedônia - $\mathrm{SiO}_{2}$ )}

A Formação Teresina apresenta silicificação pervasiva de diversos níveis e camadas de calcários, o que resultou em alteração das feições primárias. A calcedônia é o constituinte diagenético predominante das rochas da Formação Teresina, juntamente com a calcita. Na região de Jacarezinho, a fácies chert nodular brechado ocorre intercalada a calcários e apresenta aglomerados de nódulos de calcedônia, muitas vezes alongados na direção do acamadamento e deformados, com tamanho milimétrico a centimétrico (até $5 \mathrm{~cm}$, eixo maior), em leitos de espessura entre 2 e 8 cm (Figura 14 A-B). O chert também ocorre como camadas contínuas, formando dobras enterolíticas (Figura 14C). Nas áreas entre Jacarezinho e Santo Antonio da Platina, foram observados diversos fósseis de troncos silicificados desprovidos de feições de compactação mecânica. Isto sugere silicificação precoce (Figura 14D). Em Taguaí, a calcedônia ocorre na fácies chert bandado e forma lentes deformadas ou concreções esféricas a ovaladas com até $10 \mathrm{~cm}$ de diâmetro (eixo maior) na base da fácies packstone/grainstone oolítico (Figura $14 \mathrm{E}-\mathrm{G}$ ). Na fácies rudstone bioclástico, a calcedônia substitui principalmente bioclastos de bivalves (Figura 14H). O chert também forma estruturas cônicas e também ocorre como cimento ou mineral de substituição de calcários presentes na região de Anhembi. No interior dessas estruturas cônicas silicosas ocorrem geodos com cristais de quartzo euédricos (Figura 14I). Na Formação Corumbataí entre os municípios de Ipeúna e Rio Claro foram observadas fraturas subverticais com preenchimento por cristais de quartzo. Os cristais de quartzo são aciculares e dispostos perpendicularmente às paredes das fraturas. Estes cristais formam veios com espessura média de 2 a $5 \mathrm{~cm}$ e direção NW 
a NNW, os quais cortam siltitos roxo-acinzentados da Formação Corumbataí. Veios de quartzo horizontais, com espessura entre 10 e $80 \mu \mathrm{m}$, também foram observados em lâminas delgadas das fácies heterolíticas da Formação Teresina. Contudo, veios de quartzo são mais freqüentes na Formação Corumbataí em relação à Formação Teresina.
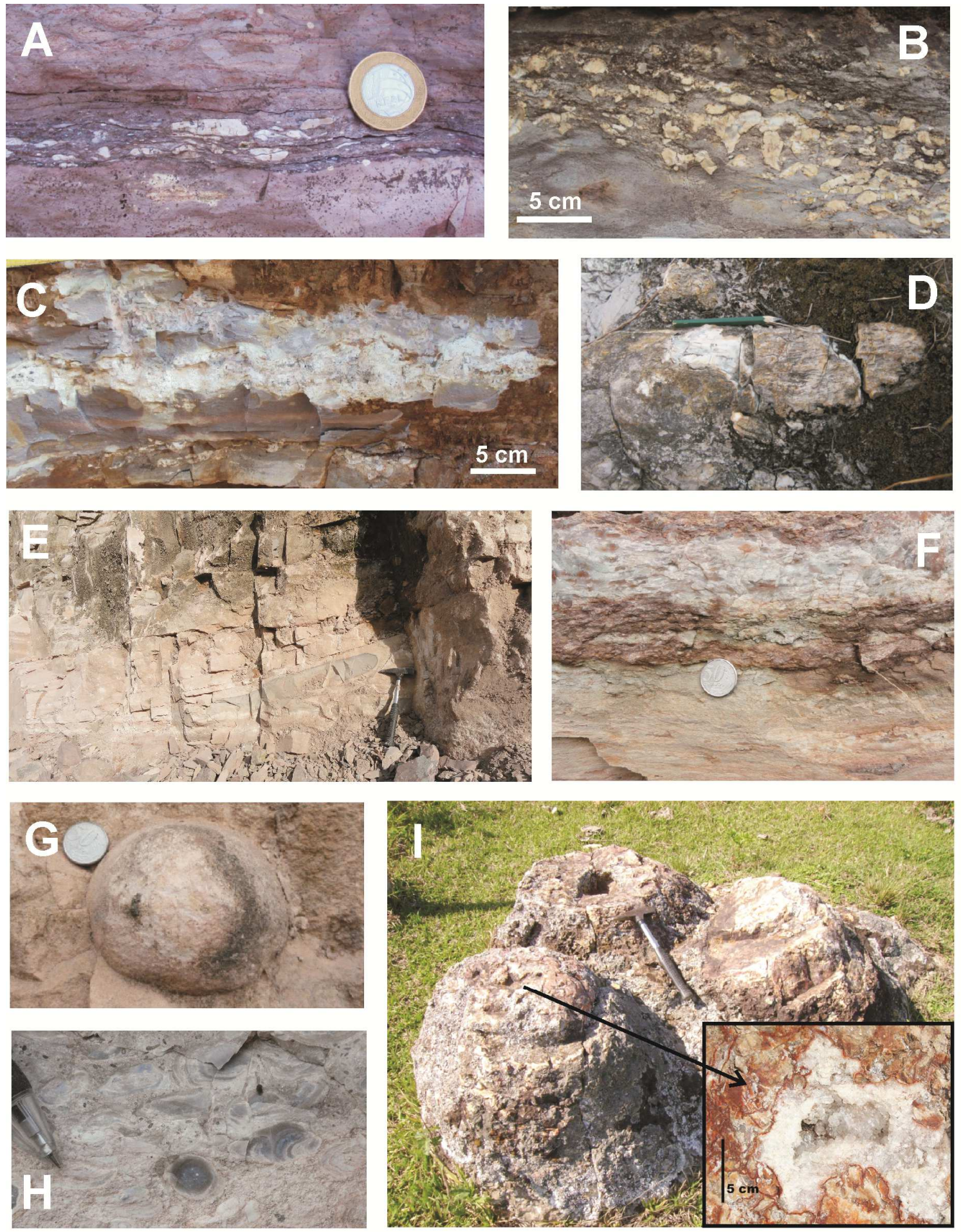

Figura 14. A e B) Chert nodular brechado com nódulos de calcedônia deformados de até $5 \mathrm{~cm}$ de diâmetro (eixo maior) (afloramentos JZ-05 e JZ-07, respectivamente, Jacarezinho); C) Nível de chert com dobra enterolítica em arenito muito fino com 
laminação plano-paralela e cimento carbonático (afloramento JZ-03, Jacarezinho); D) Fóssil de tronco vegetal silicificado (afloramento JZ-07, Santo Antonio da Platina); E) Níveis contínuos e deformados de chert que acompanham estratificação das camadas de packstone/grainstone oolítico (afloramento IP-06, Mineração de Calcário Irmãos Gobbo, Taguaí); F) Chert bandado (afloramento IP-06, Mineração de Calcário Irmãos Gobbo, Taguaí); G) Concreção silicificada (afloramento IP-06, Mineração de Calcário Irmãos Gobbo, Taguaí); H) Rudstone bioclástico com conchas centimétricas (até $3 \mathrm{~cm}$ ) silicificadas (afloramento IP-06, Mineração de Calcário Irmãos Gobbo, Taguaí); I) Geodo com cristais de quartzo no núcleo de cone silicoso (afloramento IP-22, Anhembi).

Em escala microscópica, observa-se que os componentes autigênicos silicosos ocorrem como calcedônia fibro-radiada ou sacaroidal, cristais de megaquartzo em mosaicos ou como cristais euédricos de quartzo com terminação piramidal. A calcedônia fibro-radiada e os cristais de megaquartzo geralmente ocorrem no preenchimento de poros e cavidades, enquanto que a calcedônia sacaroidal pode ocorrer como mineral de substituição ou de preenchimento de poros.

A calcedônia fibro-radiada e a sacaroidal ocorrem como cimentos de porosidades intergranulares da fácies packstone/grainstone oolítico. Nesta fácies, observa-se que a calcedônia foi formada após fase de cimentação de calcita espática precoce, que ocorre como envoltório de oóides com textura dente de cão, e após compactação mecânica incipiente. Esta compactação é caracterizada por porções em que os oóides apresentam contatos pontuais e, raramente, contatos planares ou irregulares. Oóides fraturados são raros, o que indica baixa compactação mecânica (Figura 15).

A calcedônia sacaroidal também ocorre principalmente na substituição parcial da matriz micrítica dos calcários, o que resultou em textura mosqueada evidente sob luz polarizada, dada pelo contraste entre a birrefringência mais elevada da calcita em relação à calcedônia.

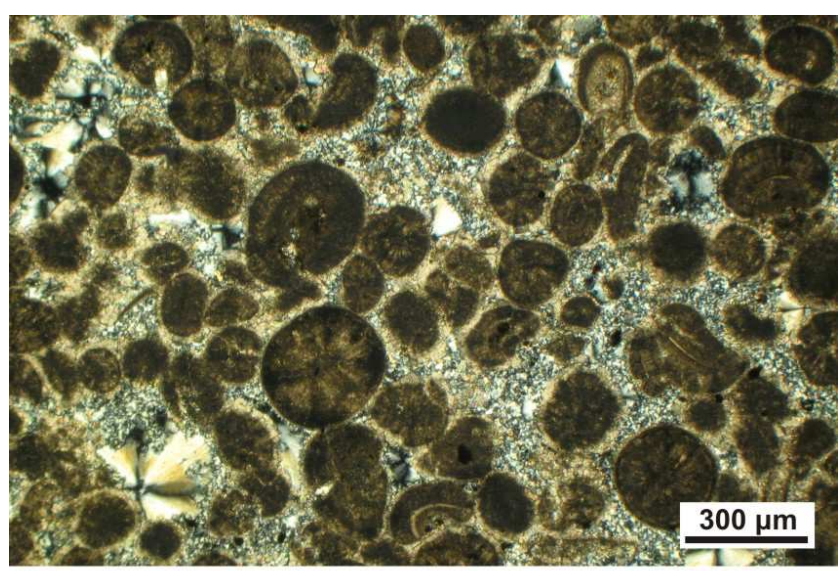

Figura 15. Calcedônia sacaroidal e fibro-radiada em poros intergranulares de grainstone oolítico com compactação mecânica incipiente. Lâmina JZ15A. 
A calcedônia fibro-radiada e o megaquartzo preenchem cavidades de dissolução da fácies chert nodular brechado. O arranjo dos cristais de calcedônia fibroradiada com limites poligonais e término em ponto tríplice pode indicar que são cimentos de preenchimento de cavidades (Figura 16 A-B).
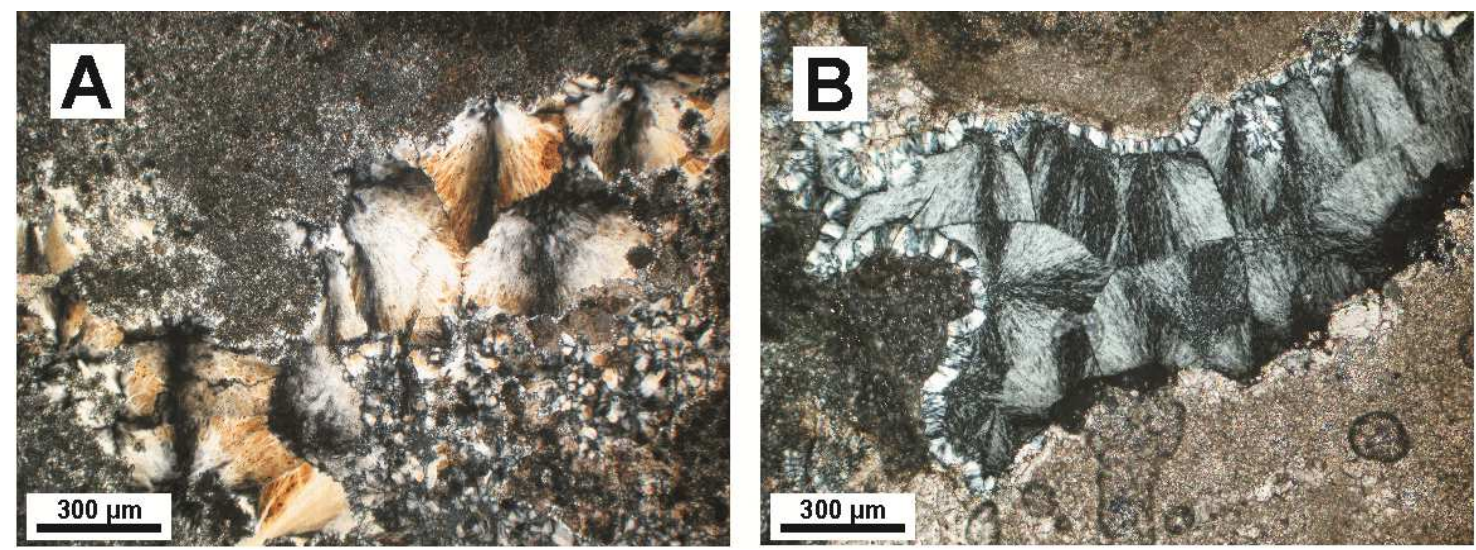

Figura 16. A e B) Calcedônia fibro-radiada em cavidade de dissolução da fácies chert nodular brechado e matriz substituida por calcedônia sacaroidal. Imagens sob polarizadores cruzados. Lâmina IP-06-R7.

Os cristais de megaquartzo que ocorrem na borda das cavidades da fácies chert nodular brechado (Figura 17A) possuem diâmetro de até $500 \mu \mathrm{m}$ e formam agregados em mosaico, com cristais em contatos curvos e/ou planares, os quais podem estar recobertos por cristais euédricos a subeuédricos. Os cristais apresentamse límpidos e aparentemente desprovidos de inclusões. Cristais de megaquartzo também ocorrem nos cones silicosos da região de Anhembi (SP). Esses cristais apresentam até $1 \mathrm{~cm}$ de comprimento e formam geodo no interior desses cones.

Em algumas porções da fácies microbialito observa-se que a calcedônia se alterna, em contato irregular, com níveis marrom escuro de granulação fina formados por micrita e matéria orgânica, os quais, por sua vez se alternam com níveis terrígenos (Figura 17B). Este contato deformado sugere sobrecarga e material pretérito com reologia dúctil. A presença de níveis micríticos e matéria orgânica poderiam ser interpretados como produto de esteiras microbiais, cuja deposição teria sido inibida por aporte de sedimentos terrígenos. Localmente, também foram observados grãos circulares com estrutura concêntrica e até $10 \mu \mathrm{m}$ de diâmetro dispersos nas porções com calcedônia e calcita espática blocosa (Figura $17 \mathrm{C}$-D). Estes grãos circulares se assemelham à zigosporos esferoidais de algas verdes (Pseudoschizaea) que apresentam como estrutura interna anéis concêntricos estreitos (Medeanic et al., 2006). Zigosporos de Pseudoschizaea são descritos em depósitos de turfas lagunares do Holoceno. Isto indica que podem ocorrer tanto em ambientes de água doce como 
salino. A presença de zigosporos de Pseudoschizaea reforçaria a influência de processos orgânicos na sedimentação na Formação Teresina, além da associação com possível ambiente misto ou salino.
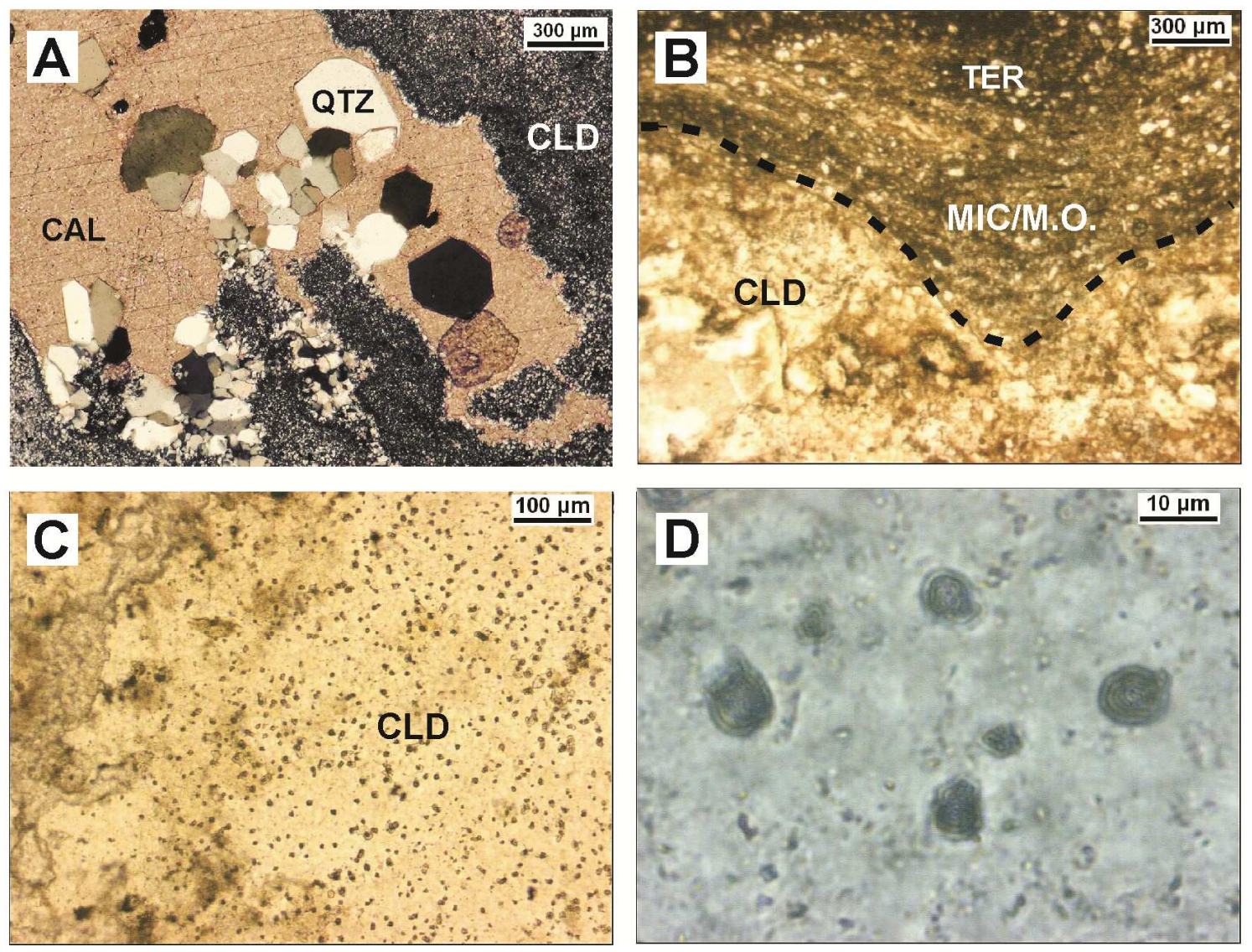

Figura 17. A) Cristais euédricos de quartzo (QTZ) em cavidades da fácies chert nodular brechado. A calcita espática blocosa $(\mathrm{CAL})$ preenche o restante da cavidade, após crescimento de quartzo. Lâmina JZ-05. Imagem sob polarizadores cruzados; B) Intercalação de níveis de calcedônia (CLD), em contato deformado, com níveis marrom escuros de micrita (MIC) ou matéria orgânica (M.O), com incremento gradativo de sedimentos terrígenos (TER). Lâmina JZ-03B. Imagem sob polarizadores paralelos; C e D) Zigosporos de Pseudoschizaea com estrutura concêntrica circular a irregular, dispersas em matriz de calcedônia (CLD). Lâmina JZ-03B. Imagens sob polarizadores paralelos.

Nódulos de calcedônia ocorrem na fácies chert nodular brechado e na fácies de marga parcialmente silicificada. O contato desses nódulos com as camadas adjacentes apresenta feições de sobrecarga caracterizada pela deformação da laminação no entorno dos nódulos (Figura 18). Os nódulos também parecem estar associados a feições de exposição subaérea. Essas feições caracterizam-se pela ocorrência de fraturas irregulares de pequena extensão preenchidas por calcita espática que circundam ou cortam os nódulos e a matriz. A associação dessas feições (nódulos e fraturas) resulta em textura que pode corresponder a possível paleossolo 
carbonático-evaporítico que sofreu dissecação e brechação (Figura 19). Feição estilolítica, caracterizada por filme irregular de material marrom, ocorre entre nódulos de calcedônia (Figura 20) na fácies mudstone.
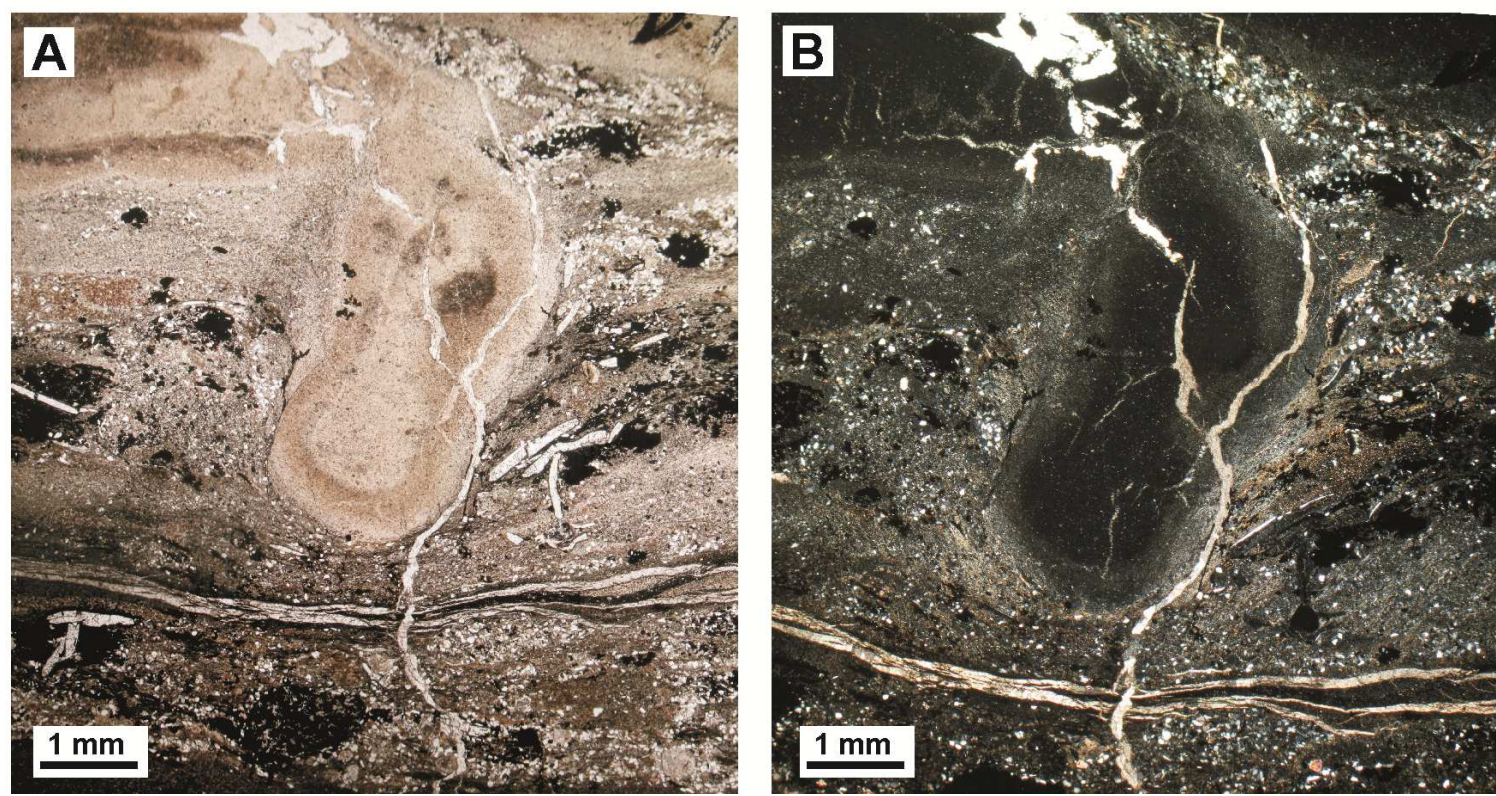

Figura 18. A e B) Nódulo de calcedônia na fácies marga parcialmente silicificada e feição de sobrecarga no entorno desse nódulo. Imagens sob polarizadores paralelos e cruzados, respectivamente. Lâmina: JZ-05C

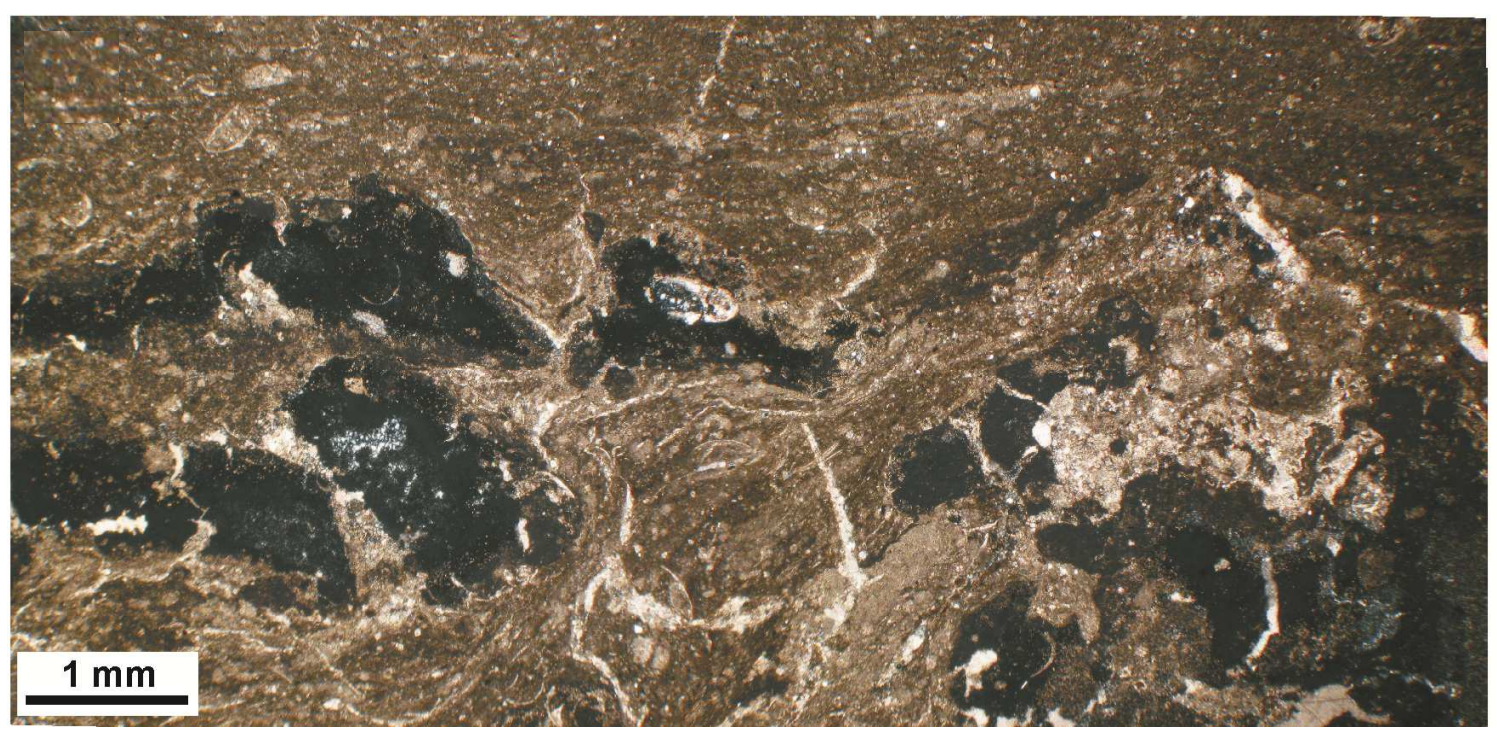

Figura 19. Micrito da fácies wackestone bioclástico ocorrem deformados e rotacionados em volta de nódulos de calcedônia. Fraturas de pequena extensão cortam os nódulos e a matriz e estão preenchidas por calcita espática. Imagem sob polarizadores cruzados. 

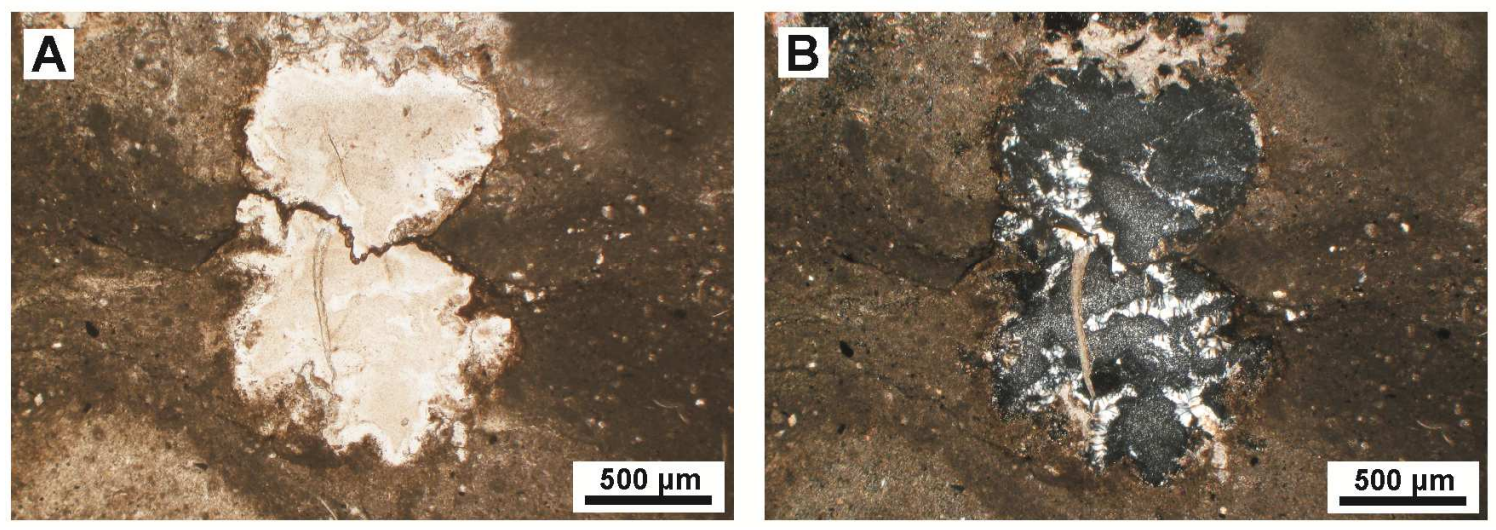

Figura 20. A e B) Contato suturado (estilólito) entre nódulos de calcedônia em fácies mudstone. Imagens sob polarizadores paralelos e cruzados, respectivamente. Lâmina JZ-07A.

\subsubsection{Calcita - $\mathrm{CaCO}_{3}$}

Veios de calcita paralelos ao acamamento (veios beef sensu Rodrigues et al., 2009) ocorrem em fácies heterolíticas da Formação Teresina e em siltitos da Formação Corumbataí. Veios verticais de calcita são mais comuns em diques básicos alojados na Formação Teresina, principalmente na região de Taguaí e Fartura. Na Formação Teresina, a espessura dos veios horizontais de calcita varia de $20 \mu \mathrm{m}$ a 2 $\mathrm{cm}$. Estes veios estão concentrados em intervalos da fácies de siltito arenoso/argiloso com laminação heterolítica (Figura 21). Na Formação Corumbataí, os veios subhorizontais de calcita apresentam espessura média de 2 a $3 \mathrm{~cm}$ e ocorrem intercalados às camadas de siltitos roxo-acinzentados (Figura 22). Estes veios apresentam dobras abertas de amplitude decimétrica a métrica.

Microscopicamente, observa-se que os veios de calcita horizontais da Formação Teresina isolam fragmentos de rocha hospedeira, sendo freqüente a associação com betume (Figura 23). Os veios de menor espessura são formados por cristais prismáticos de calcita, enquanto que os mais espessos abrangem zonas de calcita eqüidimensional (equant) e fibrosa (fina e grossa). Geminações fragmentadas do tipo patch (sensu Ferrill et al., 2004) são mais freqüentes, porém, geminações tabulares (tabular twin) e em lençol (lensoid twin) também estão presentes (Figura 24). De acordo com Ferril et al. (2004), geminações do tipo patch são indicativas de recristalização dinâmica. A largura e intensidade das geminações, segundo os critérios definidos por Ferril et al. (2004), são $25 \mu \mathrm{m}$ e 18 planos de geminação/mm, respectivamente. 


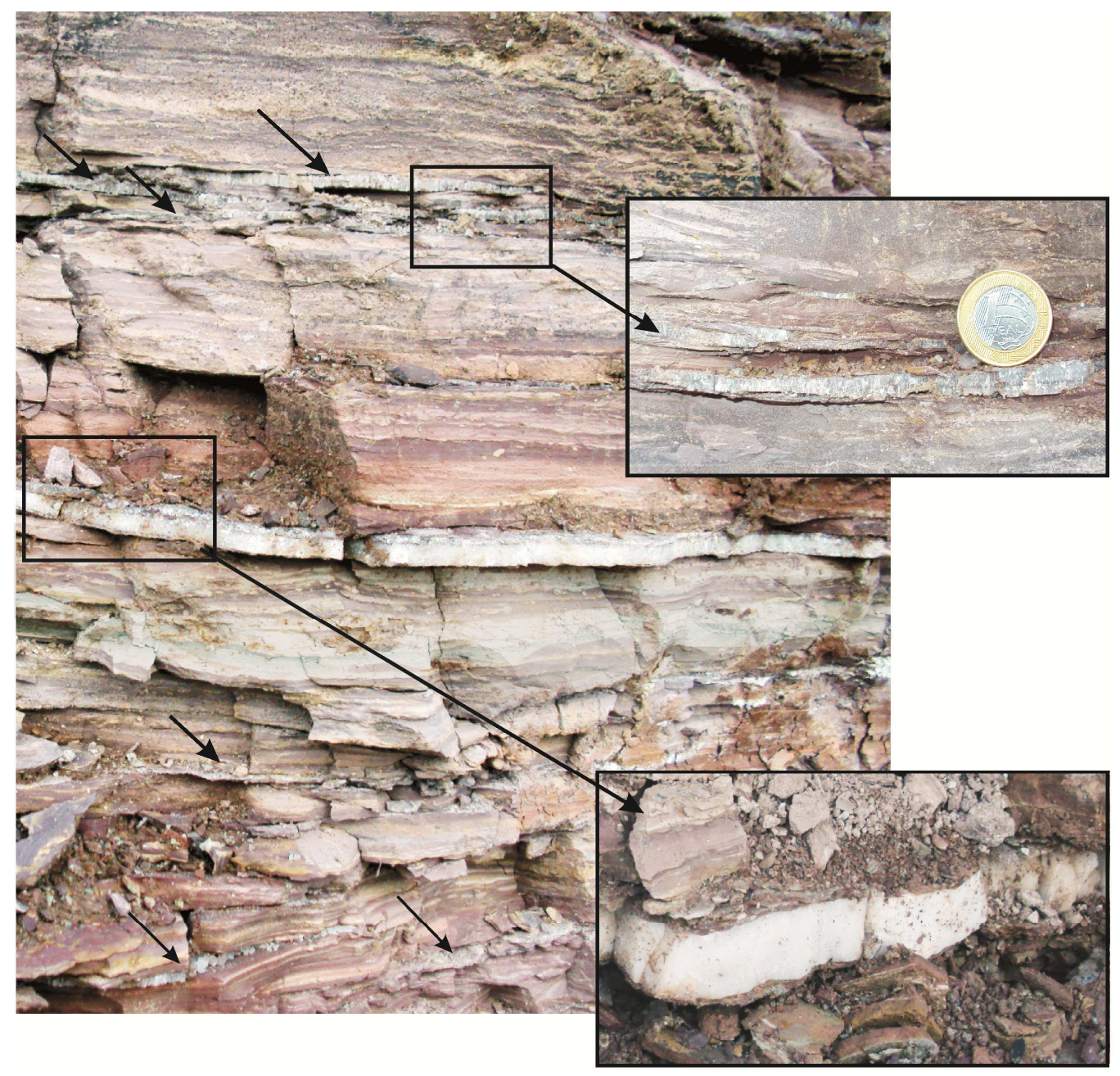

Figura 21. Veios horizontais de calcita paralelos ao acamamento (veios beef), com espessura de 0,5 a $1,5 \mathrm{~cm}$, alojados em fácies de siltito arenoso/argiloso com laminação heterolítica (afloramento IP-06, Mineração de Calcários Irmãos Gobbo, Taguaí).
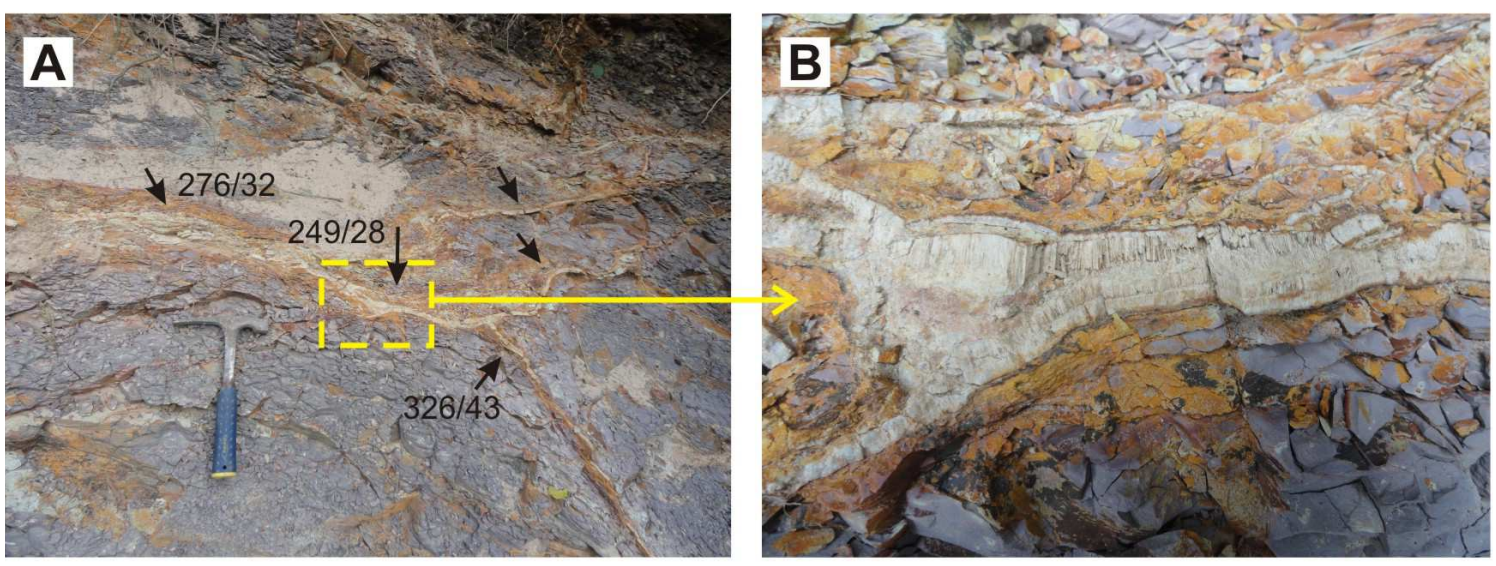

Figura 22. A) Veios sub-horizontais de calcita acicular da Formação Corumbataí. A variação das atitudes medidas em diversos veios, indicadas pelas setas (276/32, 249/28, 326/43), é resultado de deformação; B) Detalhe dos veios horizontais. Notar cristais aciculares com crescimento perpendicular ao acamadamento, além de veios ramificados e deformados. Afloramento MS-1, Ipeúna. 


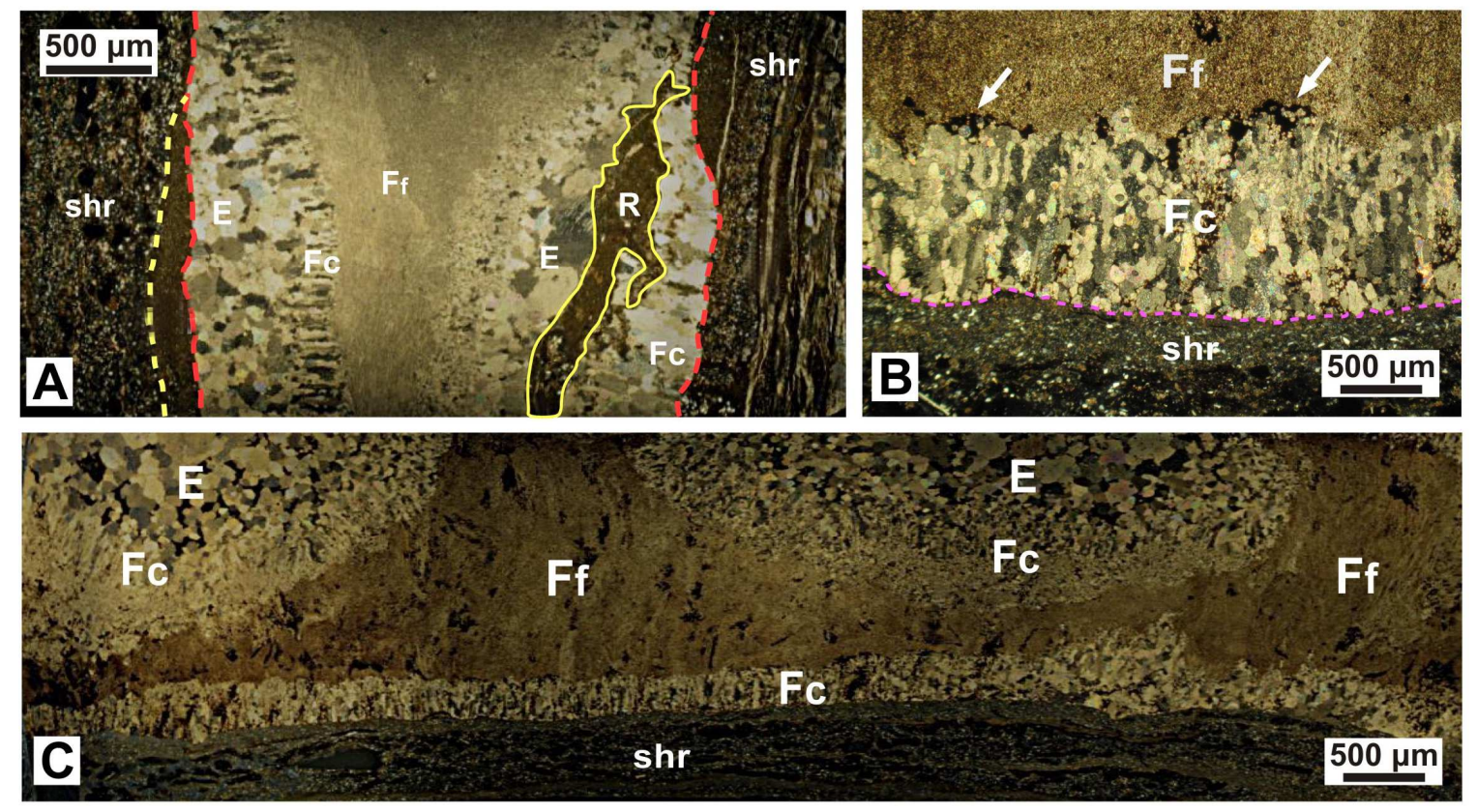

Figura 23. Texturas apresentadas pelos veios horizontais de calcita em siltito heterolítico (shr) da Formação Teresina (Taguaí). A) Calcita "equant" (E) e fibrosa grossa (Fc) estão localizadas principalmente na zona externa do veio. Calcita fibrosa fina $(\mathrm{Ff})$ localiza-se na parte central do veio. Fragmentos remanescentes da rocha hospedeira (R) estão envoltos por calcita eqüidimensional e fibrosa grossa (Fc); B) Betume (seta) no contato entre zona de calcita fibrosa grossa (Fc) e fina (Ff); C) Betume entre cristais de calcita fibrosa fina. Imagens sob polarizadores cruzados. Lâminas TER-03 e TER-07. 

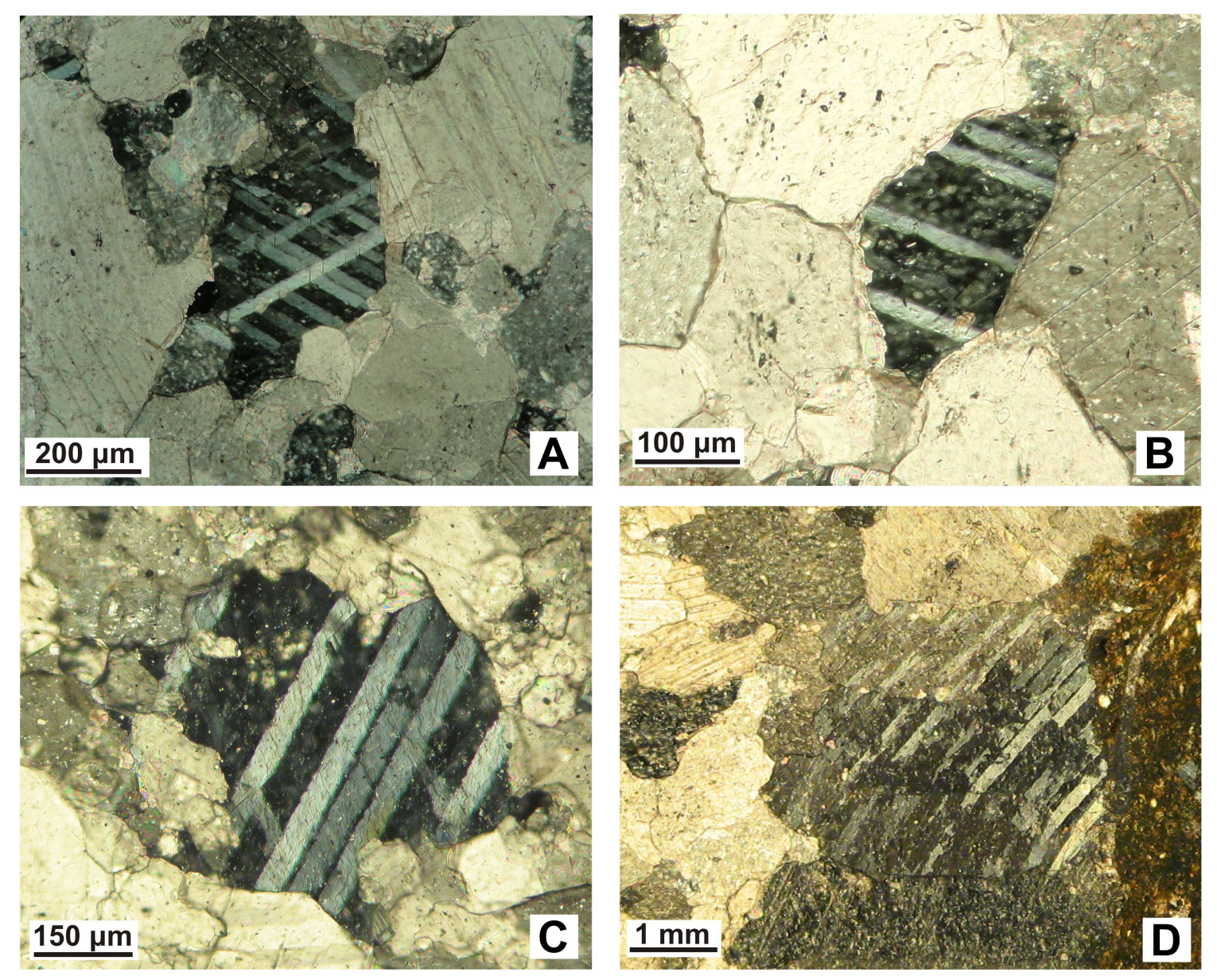

Figura 24. Diversos tipos de geminações em calcita de veio horizontal paralelo ao acamamento. A) Geminação tabular; B) Geminação em lençol (lensoid). Notar faces onduladas; C e D) Geminação fragmentada (patch). Imagens sob polarizadores cruzados.

Em Fartura, veios de calcita subverticais hospedados em diques básicos (amostra JZ-16A) apresentam espessura de 0,3 a 1,5 cm e direção NE predominante, embora veios NW também estejam presentes. Cristais de calcita eqüidimensionais formam os veios. Estes cristais também apresentam geminação fragmentada do tipo patch. Cristais de calcita espática também ocorrem como preenchimento de fenda de tração subvertical (afloramento JZ-04, amostra JZ-04A), em Jacarezinho. A fenda de tração tem direção N308 (NW) e apresenta dimensões de $35 \mathrm{~cm}$ de comprimento e 1 a $2 \mathrm{~cm}$ de largura, em planta, e secciona camadas de arenito muito fino intercalado a siltito com laminação heterolítica. Fraturas de direção N342 e N347 cortam este veio de tração. Fratura vertical de direção N333 e N326 (NW) também ocorre preenchida por cristais de calcita espática com dimensões do eixo maior de até $1 \mathrm{~cm}$. Esta fratura corta fácies de siltito heterolítico da Formação Teresina entre Santo Antonio da Platina e Joaquim Távora (afloramento JZ-10, amostra JZ-10). 
A Figura 25 apresenta as ocorrências de veios verticais de calcita na Formação Teresina nas diferentes localidades observadas.
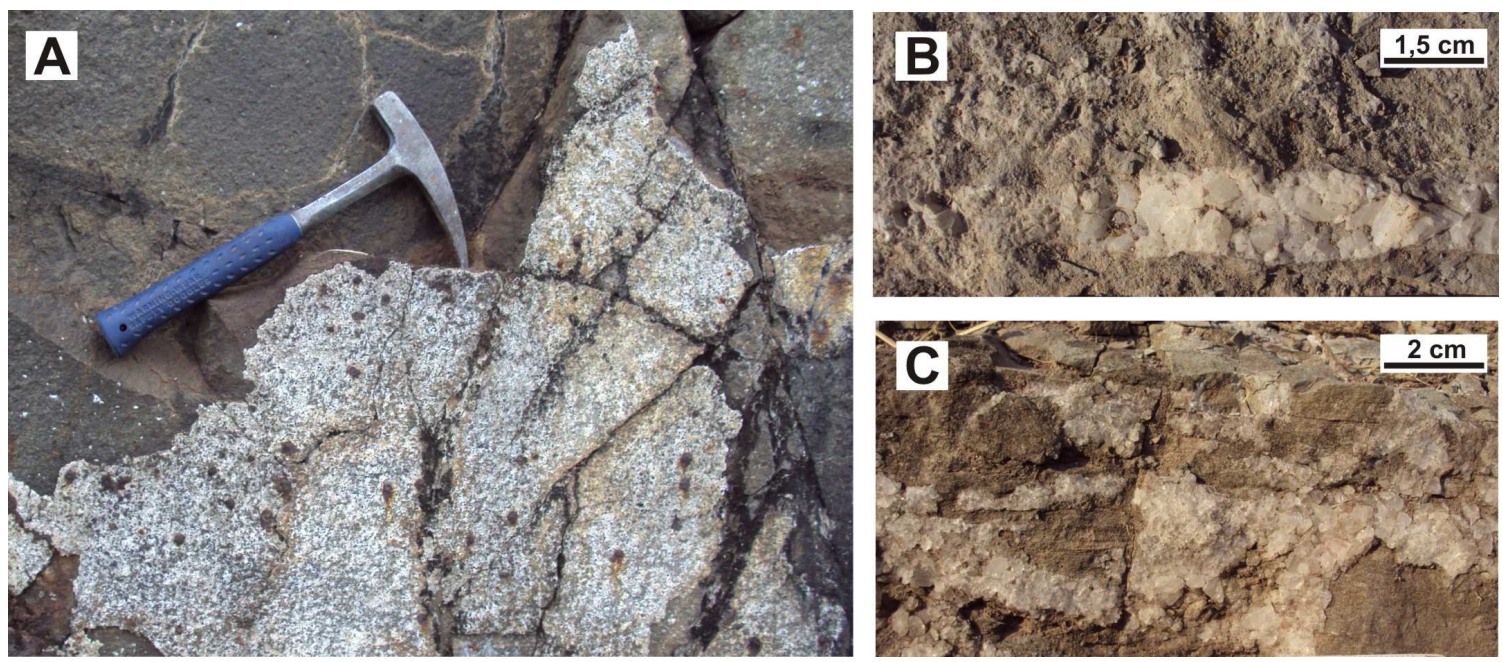

Figura 25. A) Veio vertical de calcita em dique básico em Fartura. Afloramento JZ-16 (amostra JZ-16A); B) Fenda de tração com preenchimento por calcita espática em siltito heterolítico e arenito muito fino da Formação Teresina em Jacarezinho. Afloramento JZ-04 (amostra JZ-04A); C) Fratura vertical com preenchimento por calcita espática em siltito heterolítico da Formação Teresina entre Santo Antonio da Platina e Joaquim Távora. Afloramento JZ-10 (amostra JZ-10).

A calcita também ocorre como cimento em torno de grãos de oóides na fácies grainstone oolítico. Este cimento ocorre sob duas formas: 1) morfologia em "dente de cão" tipicamente descrita como cimento precipitado em zona meteórica (Flügel, 2004), embora não se possa descartar totalmente a origem marinha; 2) remanescentes de franjas de calcita fibrosa, agora obliteradas, cuja morfologia indicaria provável origem marinha (Flügel, 2004) (Figura 26). Os cimentos em torno dos oóides seriam de fase eodiagenética e portanto, anteriores à principal fase de compactação mecânica.
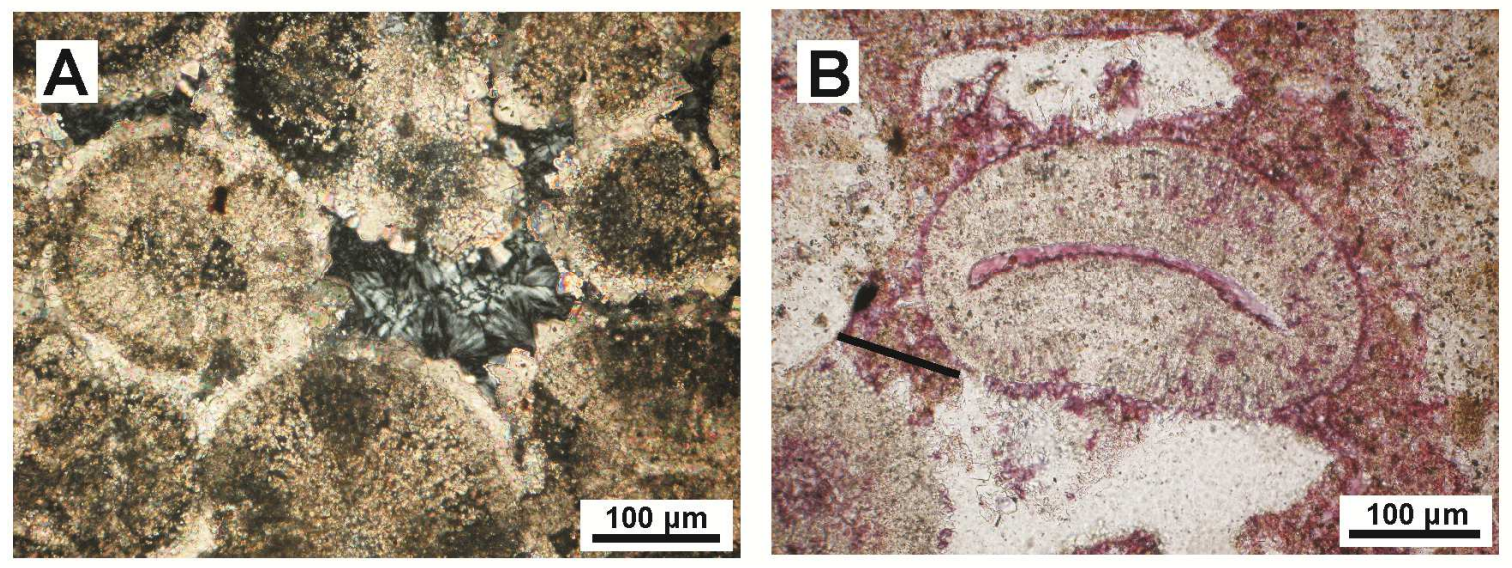

Figura 26. A) Oóides com envelopes de cristais de calcita com textura dente de cão (lâmina T1). Imagem sob polarizadores cruzados; B) Oóides com envelopes de cristais de calcita em franja fibrosa. Lâmina JZ-10C. Imagens sob polarizadores paralelos. 
A calcita também ocorre como cristal blocoso (blocky) caracterizado por ser um cristal único e com centenas de micrômetros de diâmetro. A calcita blocosa apresenta geminações principalmente do tipo tabular e fragmentada (patch) bem formada e ocorre como cristal grosso a muito grosso no preenchimento de cavidades de dissolução nos diversos níveis da fácies chert nodular brechado e packstone/grainstone oolítico brechado parcialmente silicificado. Em geral, o preenchimento das cavidades inicia-se com cristais de quartzo ou calcedônia na borda. Nessas fácies a calcita também ocorre em fraturas de pequena extensão, direção variável e fechamento abrupto. A Figura 27 apresenta diversos estilos de preenchimento das cavidades da fácies chert nodular brechado por calcita blocosa. A calcita blocosa tem sido descrita como indicativa de estágio avançado de soterramento ou de origem hidrotermal (Flügel, 2004).
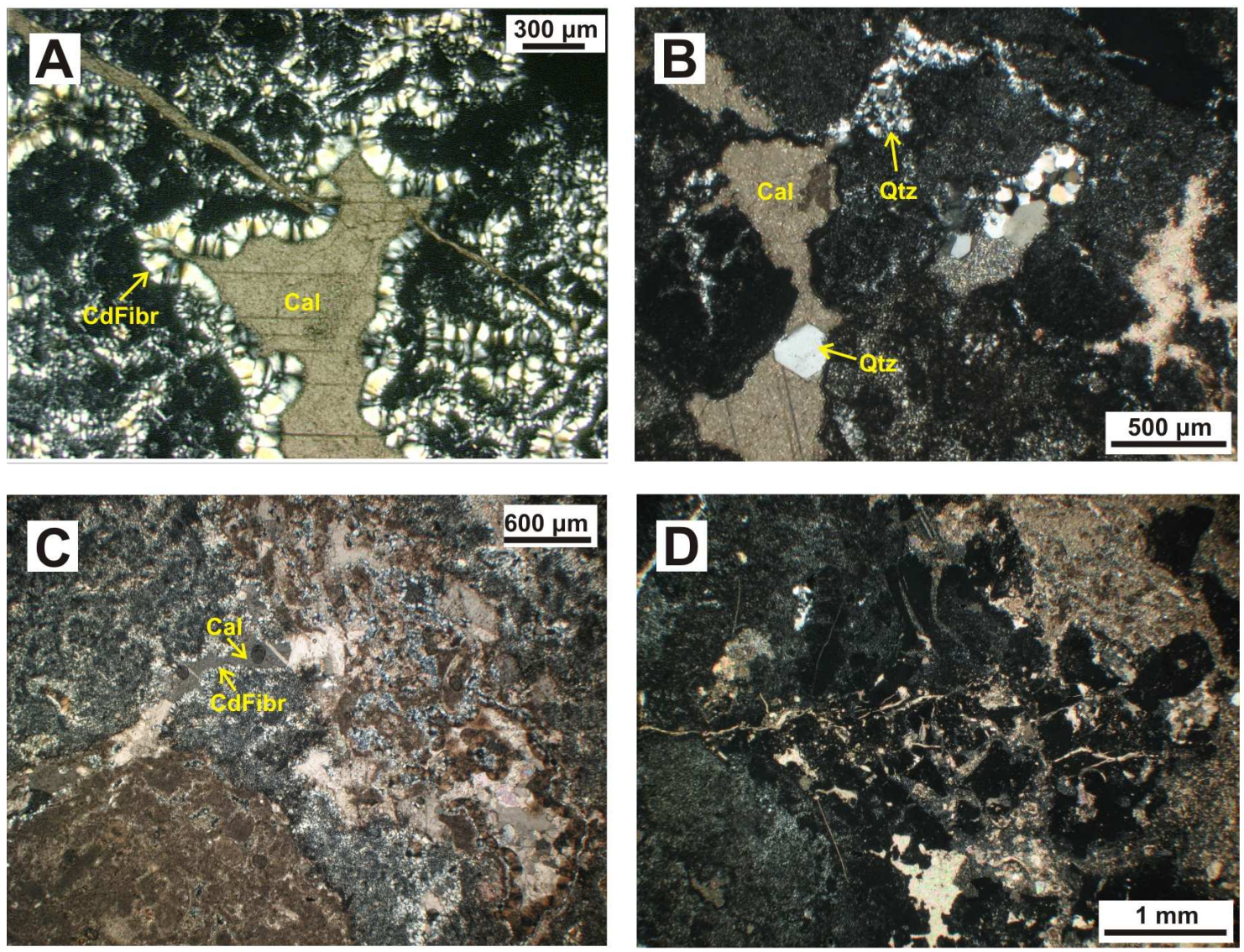

Figura 27. Fácies chert nodular brechado (A e B) e packstone/grainstone oolítico brechado (C) com cavidades de dissolução preenchidas por calcita blocosa (Cal). Fácies Notar que algumas cavidades apresentam crescimento de calcedônia fibroradiada (CdFibr) ou cristal de quartzo euédrico (Qtz) anteriores à calcita blocosa; D) Calcita espática em fraturas de pequena extensão. Imagens sob polarizadores cruzados. Lâmina JZ-03B, em A; lâmina JZ-05A em B e D; lâmina IP-06-R7. 
A ocorrência de calcita moderadamente ferrosa (detectada devido à reação com ferricianeto de potássio que tingiu o cristal com colação roxa) foi observada somente na região de Joaquim Távora. Esta calcita foi reconhecida pela sua coloração lilás dada pelo tingimento por corante de ferricianeto de potássio com alizarina. A calcita ferrosa ocorre entre grãos de oóides e bioclastos representados principalmente por conchas de bivalves. A calcita ferrosa também ocorre no interior de bioclastos e no núcleo de prováveis cavidades de dissolução de algas calcárias, onde recobre calcedônia (Figura 28).
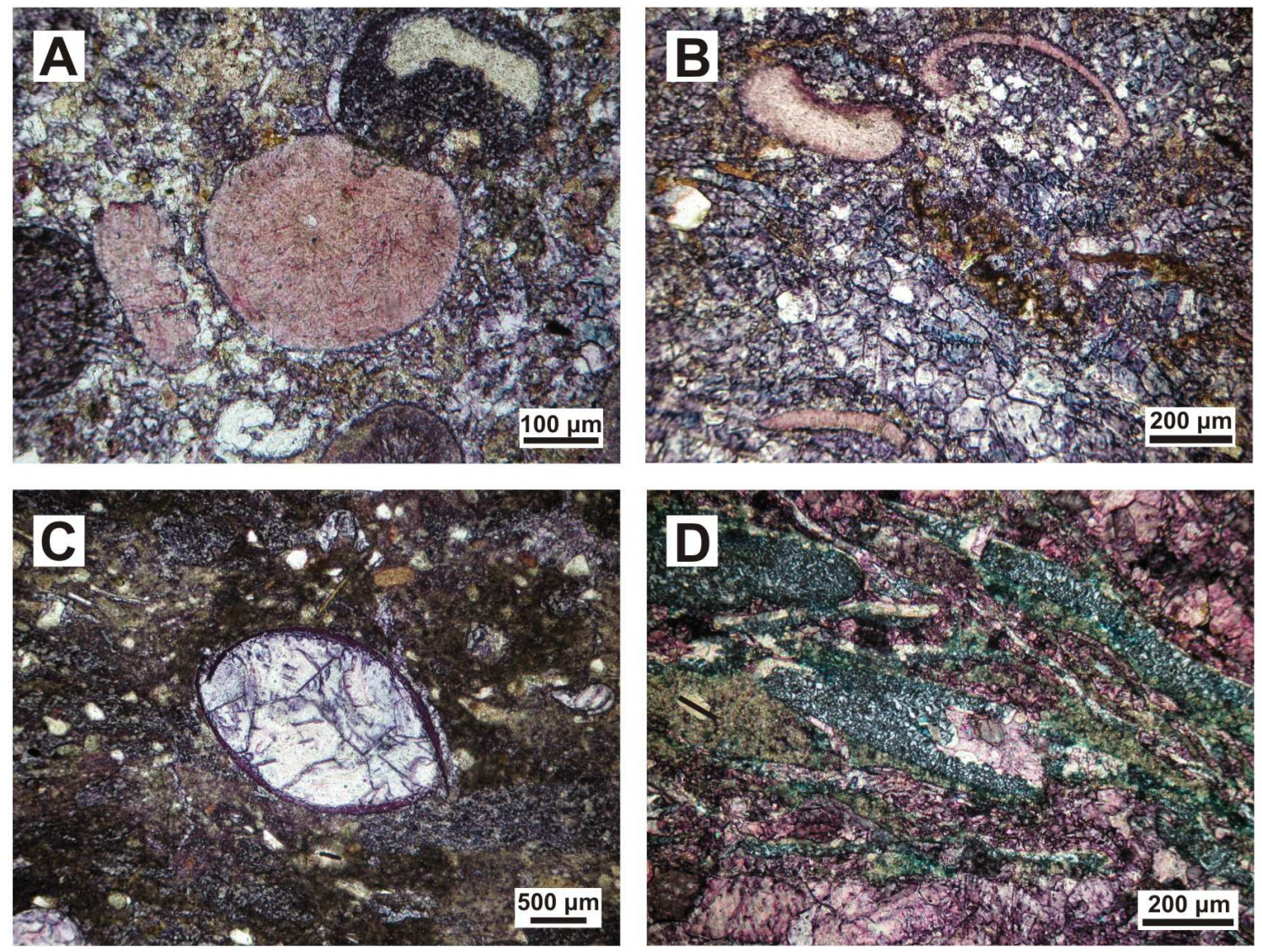

Figura 28. A, B, C e D) Calcita ferrosa espática (cor roxa) que substitui matriz micrítica ou cimento de calcita espática não-ferrosa em wackestone ou packstone/grainstone bioclástico. Alguns grãos do arcabouço também apresentam substituição ou preenchimento por calcita ferrosa $(\mathbf{A}$ e $\mathbf{C})$. Notar cavidade em núcleo de alga verde preenchida por calcita ferrosa após crescimento de calcedônia (D). Lâmina JZ-10C, em A; JZ-10D, em B e C; JZ-10G, em D.

Cristais de calcita ferrosa e veios horizontais de calcita (beef) são cortados por veios verticais de calcita espática com aproximadamente $200 \mu \mathrm{m}$ de espessura. Veios verticais de calcita também ocorrem seccionando nódulos de calcedônia da fácies de marga parcialmente silicificada (Figura 29). 

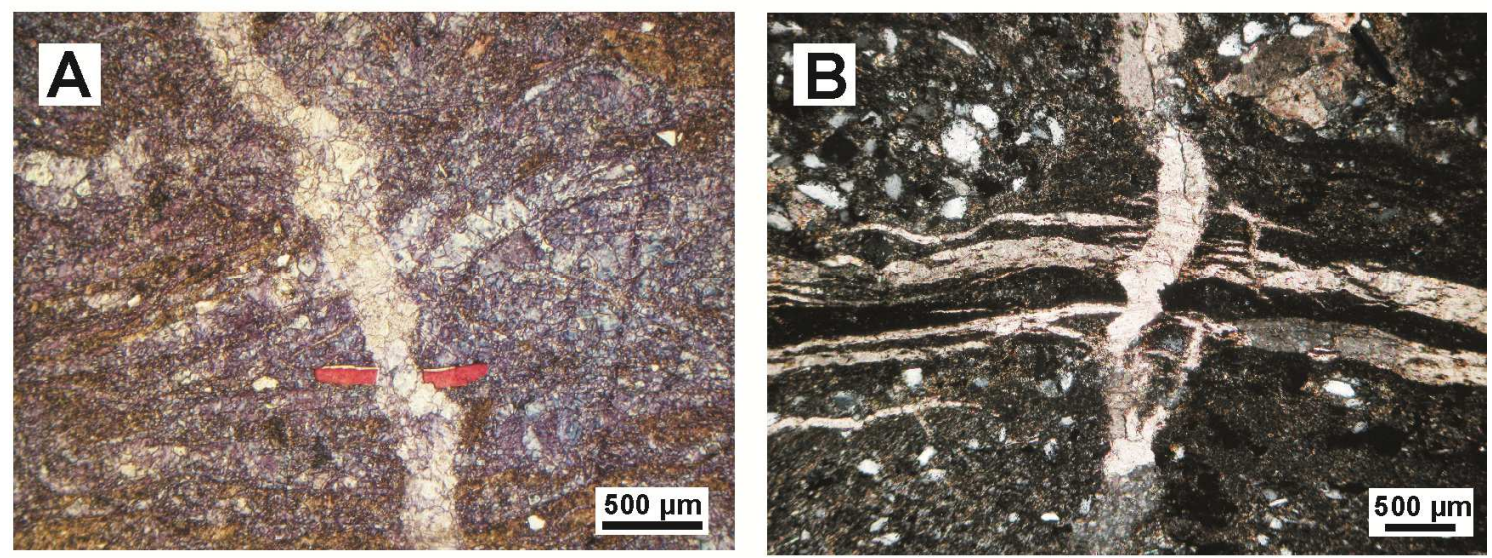

Figura 29. A) Veio vertical de calcita espática que corta cristais de calcita ferrosa. Lâmina JZ-10D. Imagem sob polarizadores paralelos; B) Veio vertical de calcita que corta veios horizontais de calcita na fácies marga parcialmente silicificada (lâmina JZ05C). Imagem sob polarizadores cruzados.

\subsubsection{Dolomita - (Ca,Mg) $\mathrm{CO}_{3}$ e pseudomorfos de calcita}

A dolomita ocorre na região de Jacarezinho como cristais romboédricos com zoneamento composicional. O tamanho dos cristais é relativamente uniforme, com diâmetro de aproximadamente $50 \mu \mathrm{m}$, os quais ocorrem dispersos em intraclastos de wackestone bioclástico silicificado presentes na fácies chert nodular brechado. Também podem formar lâminas onduladas de cristais com diâmetro entre 20 a $100 \mu \mathrm{m}$ em fácies de dolomito. A fácies de dolomito ocorre em contato com a fácies chert nodular bechado. A Figura 30 apresenta o modo de ocorrência desses cristais de dolomita zonados.

Os cristais romboédricos apresentam núcleo de aspecto mais "sujo" e borda mais límpida, o que sugere alteração distinta devido a zoneamento composicional. Análises de EDS indicaram concentração elevada de magnésio no núcleo dos romboedros, além da presença de silício e cálcio, e bordas com composição calcítica (Figura 31). Feições de corrosão ocorrem nas bordas dos romboedros, principalmente naqueles presentes na fácies wackestone bioclástico silicificado. Possíveis significados relativos a essas diferenças composicionais e texturais serão apresentados adiante no capítulo referente às discussões dos resultados. 

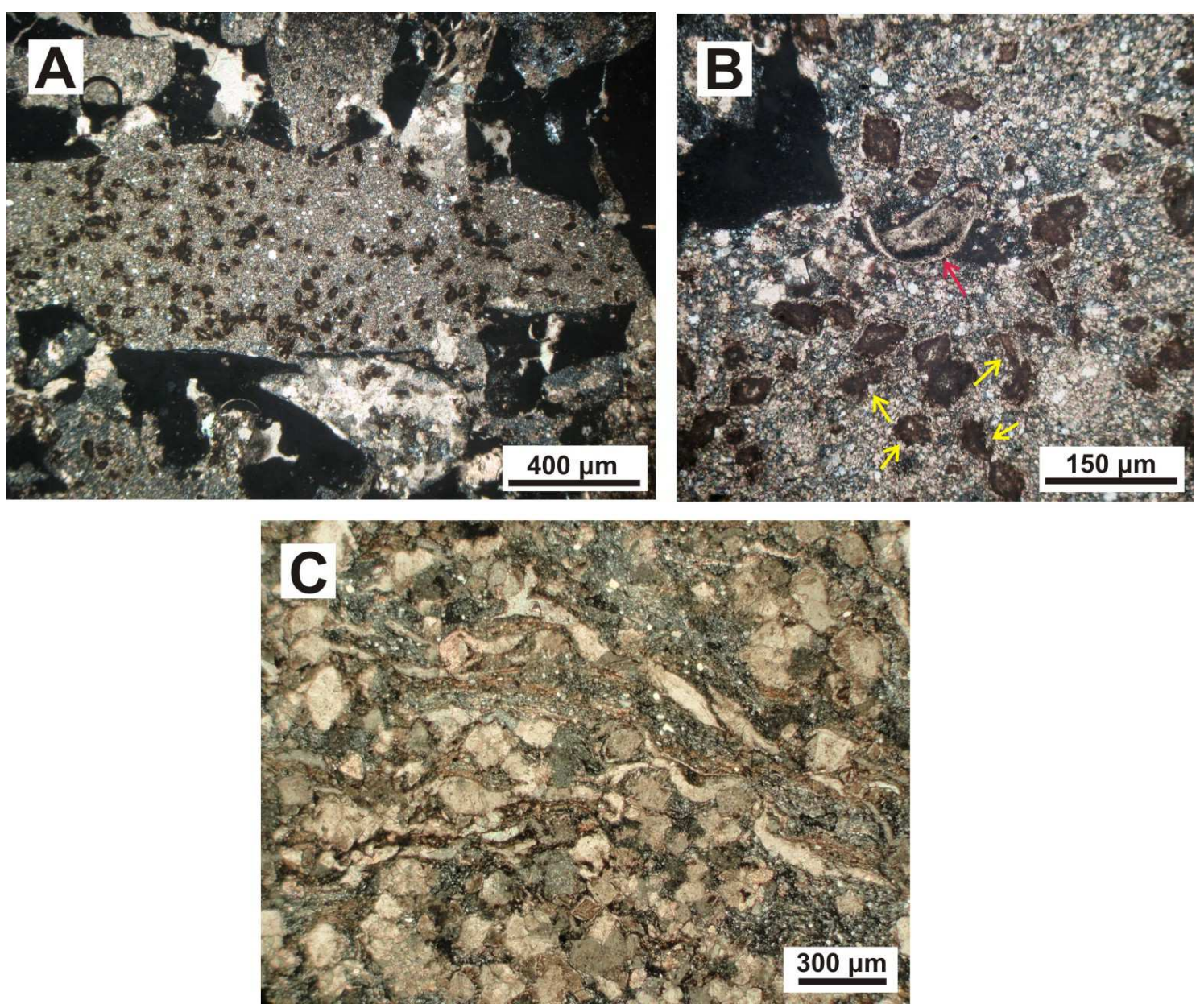

Figura 30. A) Cristais romboédricos de dolomita com zoneamento composicional e tamanho relativamente uniforme em intraclasto de wackestone bioclástico silicificado; B) Detalhe da figura anterior. Notar cristais de dolomita com borda de calcita dissolvida (seta amarela) e concha de bivalve (seta vermelha). Lâmina JZ-05A; C) Cristais romboédricos de dolomita (diâmetro de 20 a $100 \mu \mathrm{m}$ ) que formam lâminas onduladas em fácies de dolomito. Lâmina JZ-02C. Imagens sob polarizadores cruzados. 

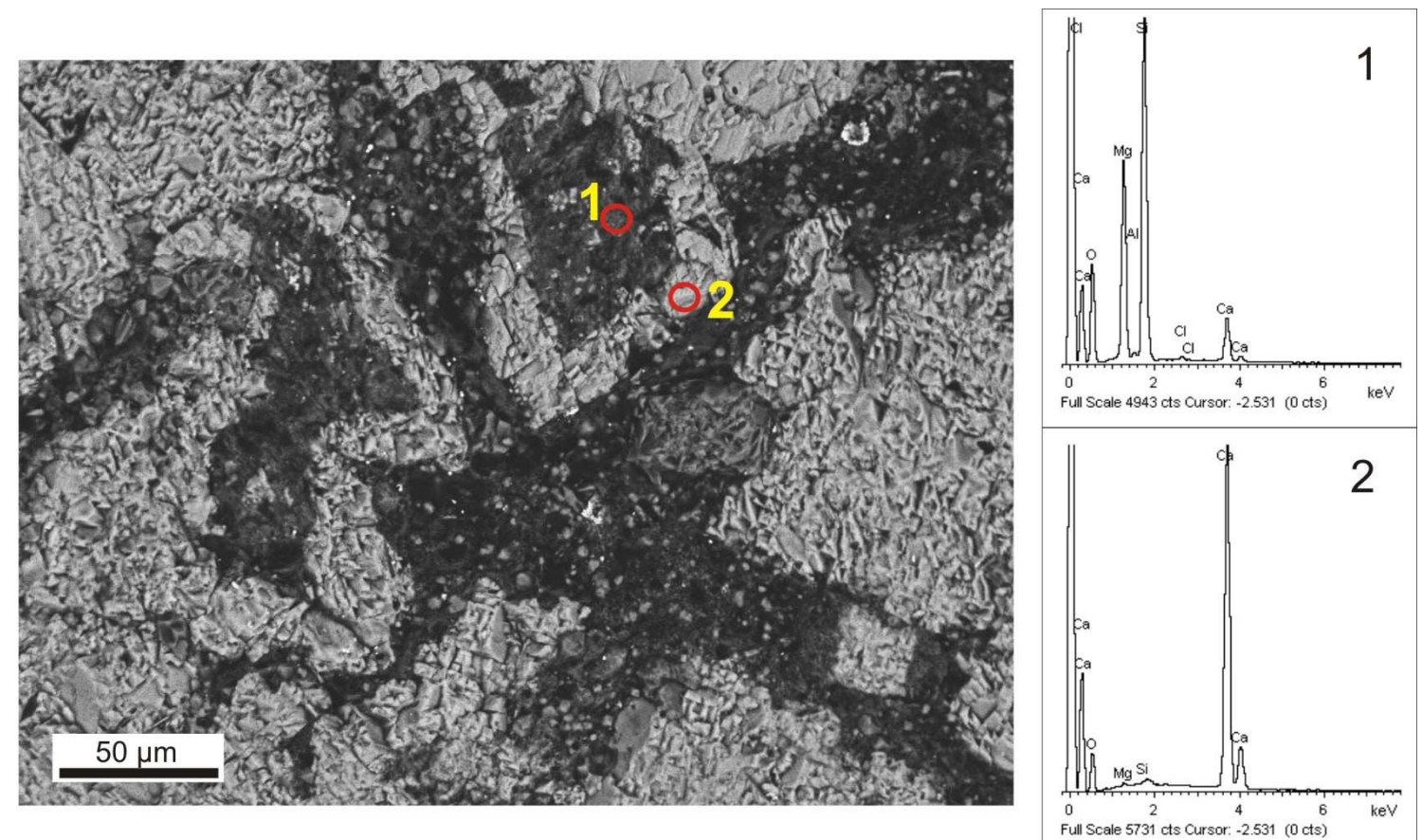

Figura 31. Análise de EDS em dolomita zonada, indicou composição de magnésio, sílica e calcita no núcleo do cristal (ponto 1) e cálcio (calcita) nas bordas (ponto 2).Lâmina JZ-02C. Imagem de elétrons retroespalhados (detector QBSD, condições: $\mathrm{EHT}=20,00 \mathrm{kV}, \mathrm{WD}=25 \mathrm{~mm}$, Mag = $1000 \mathrm{x}$ ).

A dolomita também ocorre como cristais grossos (500 a $600 \mu \mathrm{m}$ ) de cor marrom, isolados no interior das cavidades da fácies chert nodular brechado. Esta forma de ocorrência da dolomita é rara, sendo que os cristais se apresentam mais alterados por possível dissolução (ou substituição?) (Figura 32). Análises de EDS apontaram elevada concentração de magnésio no núcleo dos cristais, além de silício e cálcio. Este cristal também apresentou halo de alteração com composição calcítica, que se estende para porções do interior do cristal. Assim, a presença do sílicio e da calcita no interior desses cristais pode estar associada a possíveis processos de silicificação e calcitização, o que explicaria a textura alterada desses cristais. Isto é evidenciado pela fase mais clara da imagem de elétrons retro-espalhados da Figura 33. 

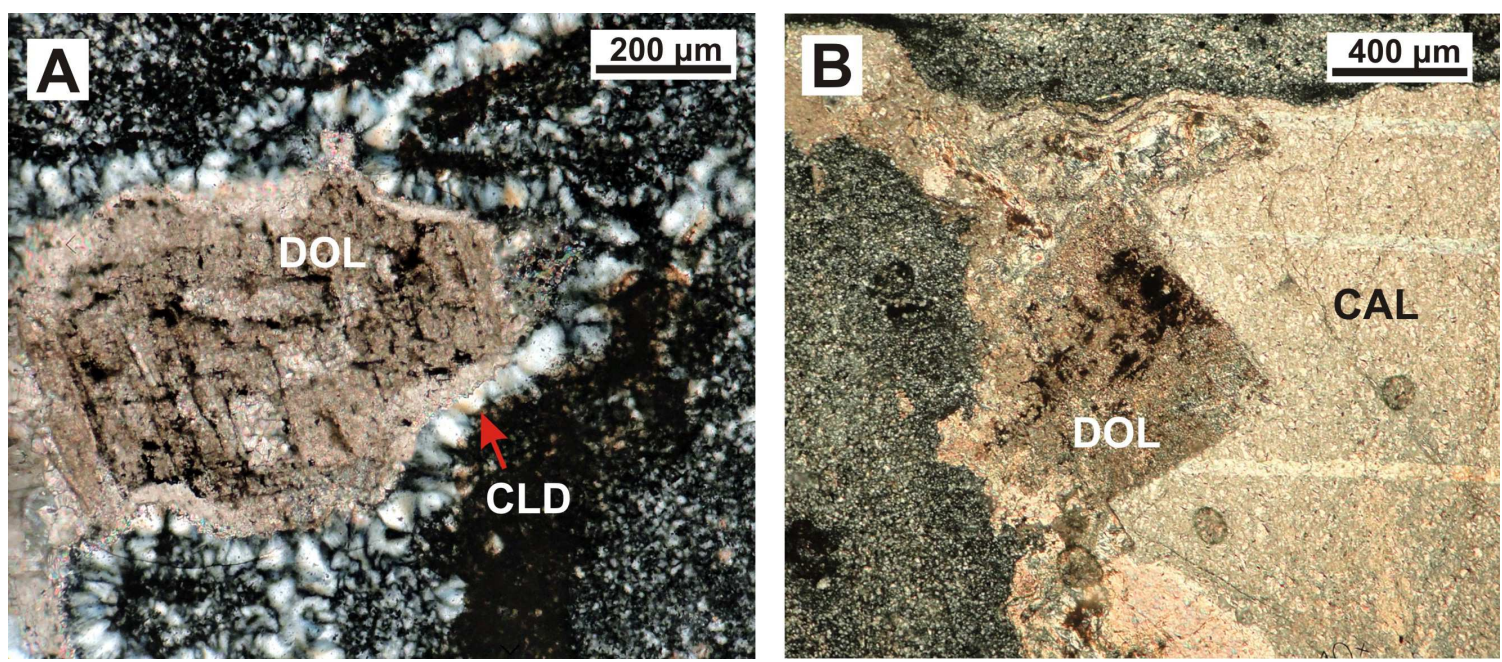

Figura 32. Cristais de dolomita (DOL) (de 500 a $600 \mu \mathrm{m}$ de diâmetro) em cavidade de chert nodular brechado. A) A dolomita ocorre após crescimento de calcedônia (CLD) na borda da cavidade (lâmina JZ-02C). B) Cristal de dolomita na borda da cavidade, seguida pelo crescimento de cristal de calcita blocosa que preenche o restante da cavidade. Lâmina JZ-05. Imagens sob polarizadores cruzados
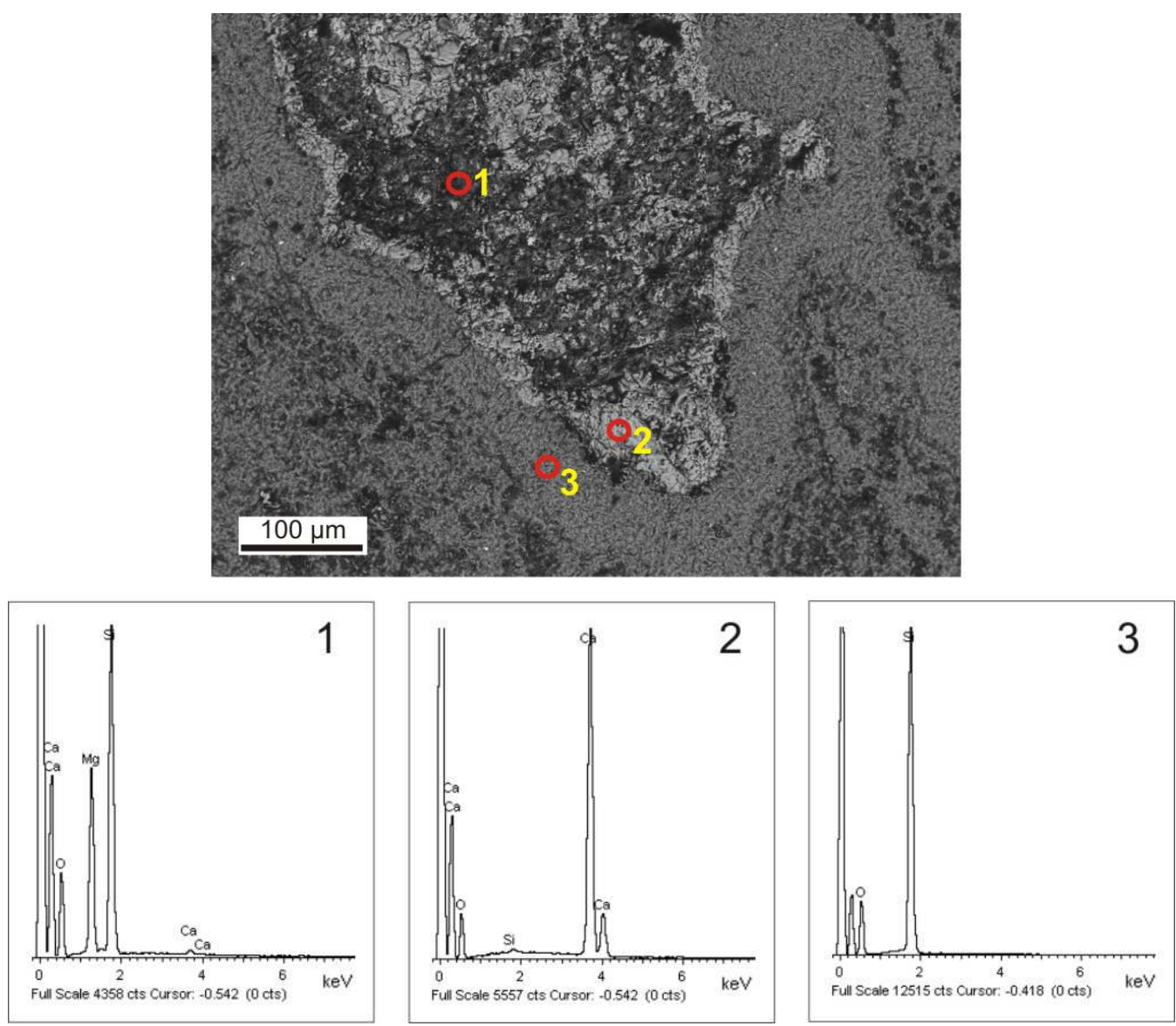

Figura 33. Análise de EDS no interior de cristal de dolomita com tamanho de aproximadamente $600 \mu \mathrm{m}$ (eixo maior) apontou elevada concentração de magnésio, além de silício e cálcio, para a fase mais escura (ponto 1). Para a fase mais clara (ponto 2), indicou predomínio de cálcio. Notar que a fase mais clara ocorre principalmente como halo ao redor do cristal, mas também aparece mosqueada em 
seu interior. Este cristal ocorre no interior de cavidade de dissolução da fácies chert nodular brechado (ponto 3). Lâmina JZ-05. Imagem de elétrons retro-espalhados (detector QBSD, condições: EHT = 20,00 kV, WD = $25 \mathrm{~mm}$, Mag = $500 \mathrm{x}$ ).

Além de cristais de dolomita, romboedros de calcita (coloração rosada na reação com alizarina) ocorrem concentrados em níveis, por vezes ondulados, ou como cristais dispersos em fácies mudstone parcialmente silicificado com níveis de terrígenos, nas regiões de Jacarezinho, Joaquim Távora (PR), Taguaí e Fartura (SP). Observou-se que os romboedros de calcita apresentaram bordas corroídas. A Figura 34 apresenta as principais formas de ocorrência dos romboedros de composição calcítica. Romboedros calcíticos ocorrem em aglomerados que formam feição de injeção na fácies mudstone parcialmente silicificado e associados à ocorrência de nódulos de calcedônia deformados (Figura 35). A ocorrência de estilólito no interior dos romboedros de composição calcítica indica que a rocha sofreu compactação química (Figura 36).
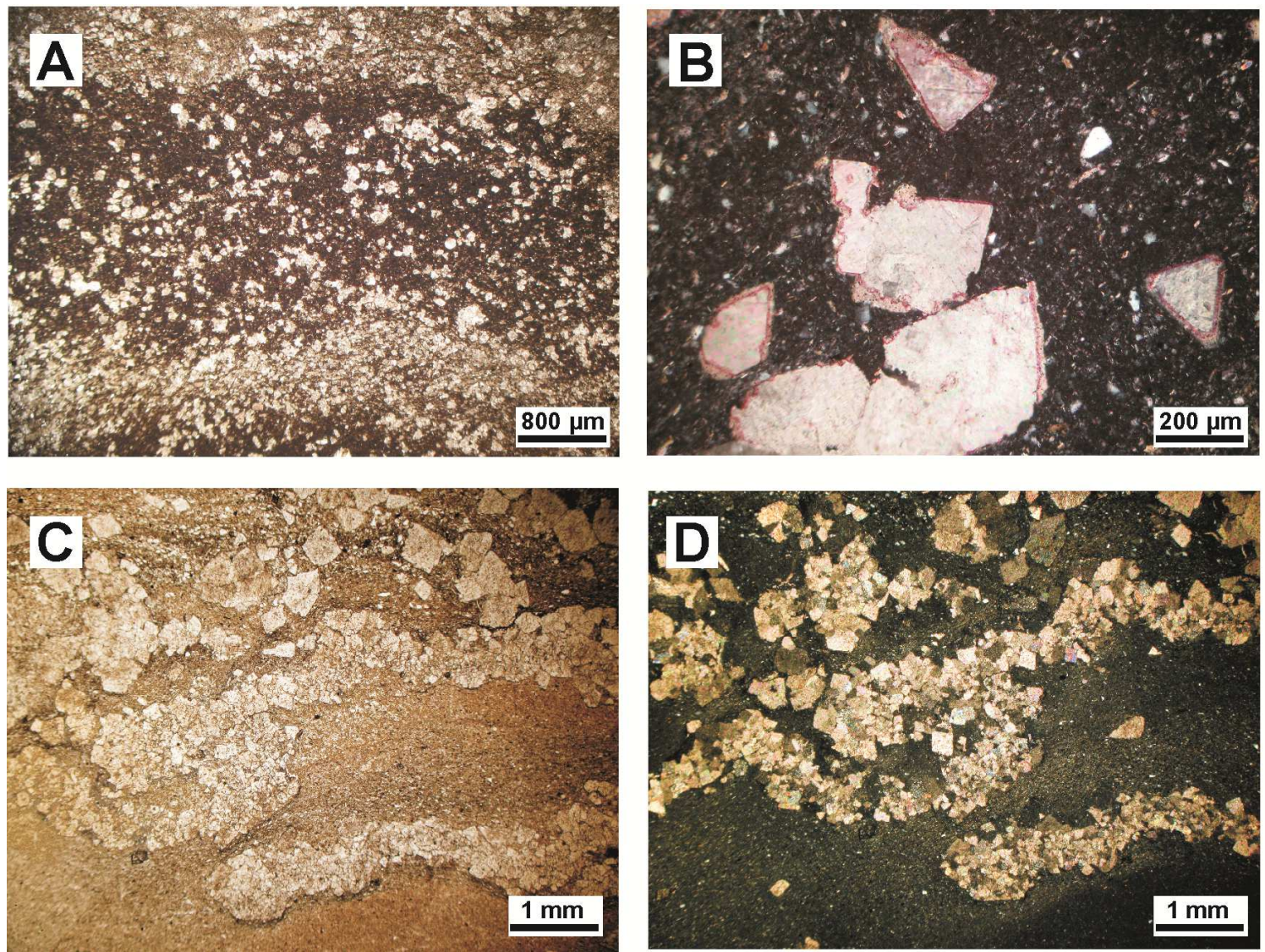

Figura 34. Formas de ocorrência de romboedros de calcita em mudstone parcialmente silicificado. A) Romboedros de calcita dispersos na matriz micrítica ou concentrados em níveis (lâmina JZ-05C); B) Romboedros de calcita zonados (notar diferentes tonalidades de rosa com tingimento por alizarina) com halo de alteração por corrosão imersos na matriz (lâmina JZ-02D); C e D) Concentração de romboedros de calcita em 
níveis ondulados (lâmina JZ-05D). Imagens sob polarizadores paralelos, em A e C. Imagens sob polarizadores cruzados, em B e D.

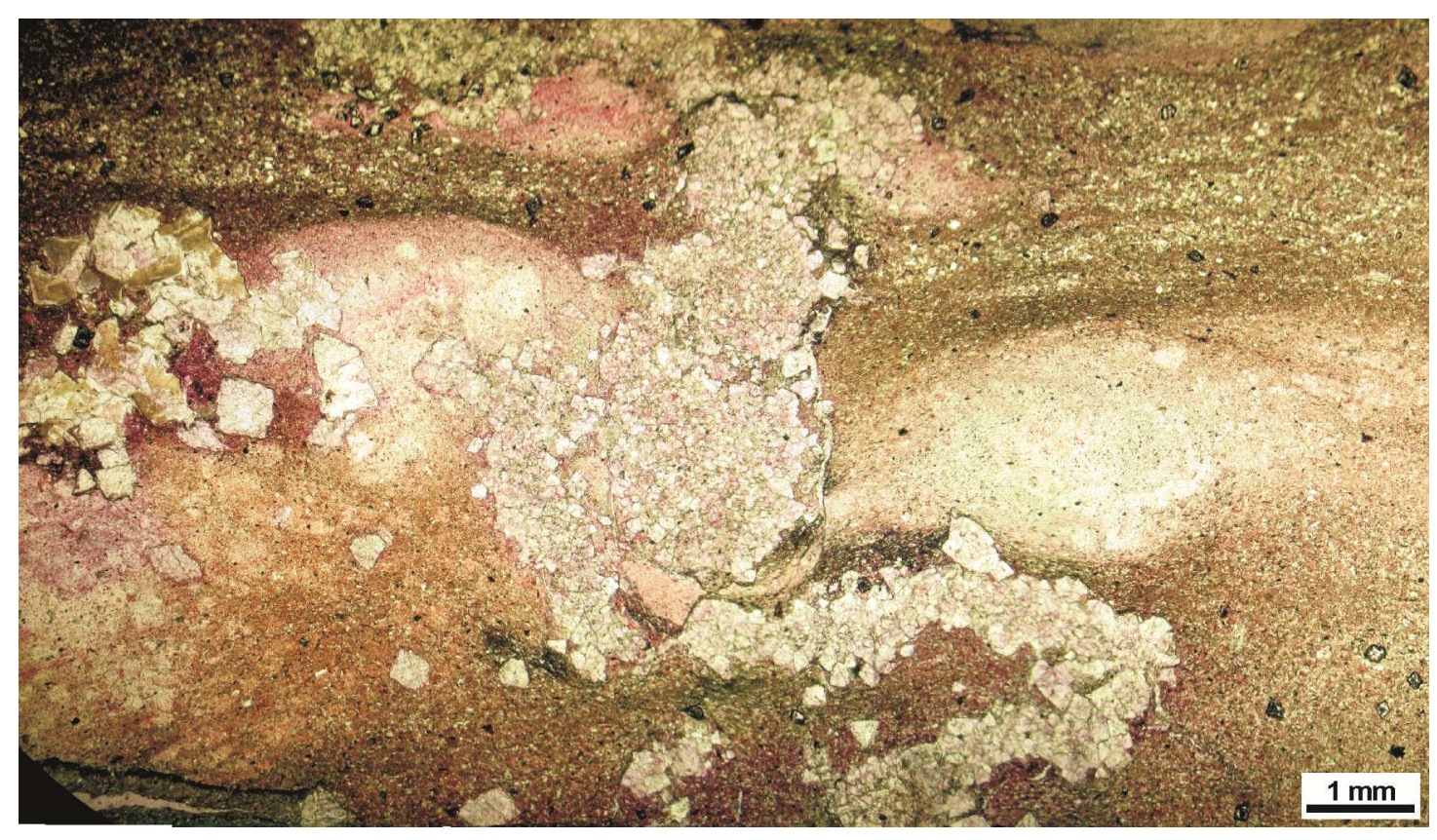

Figura 35. Aglomerado de romboedros de calcita com feição de injeção deformada em fácies mudstone parcialmente silicificado. Lâmina JZ-05D. Imagem sob polarizadores paralelos.

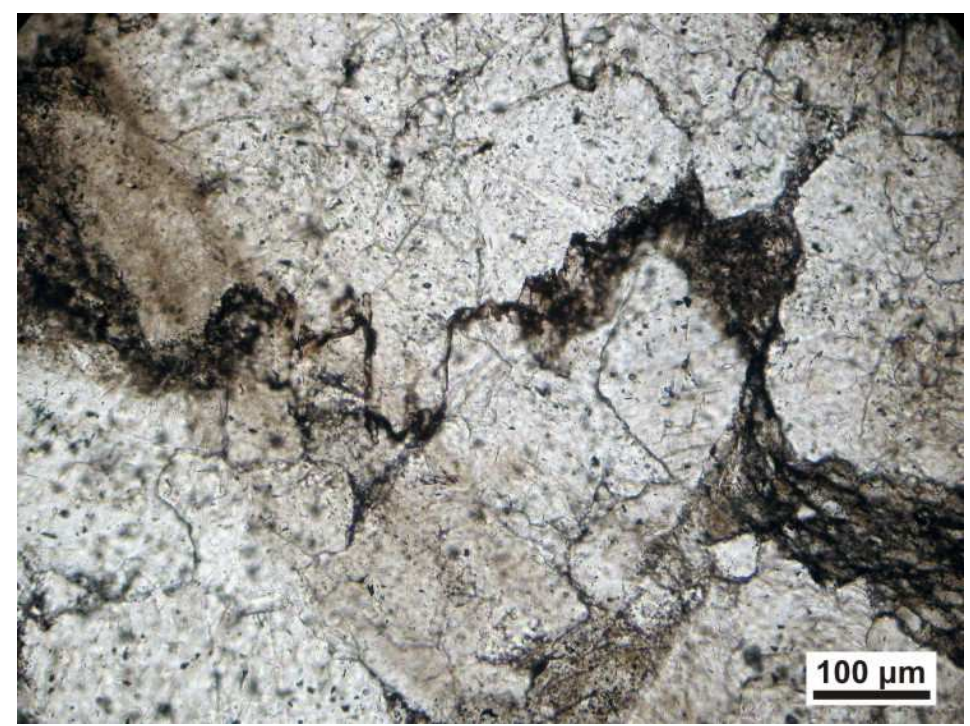

Figura 36. Estilólito em romboedros de calcita da fácies mudstone parcialmente silicificado. Lâmina JZ-05C. Imagem sob polarizadores paralelos.

Veios horizontais e verticais de calcita espática, com dezenas de micrômetros de espessura, seccionam os cristais romboédricos de calcita (Figura 37). 

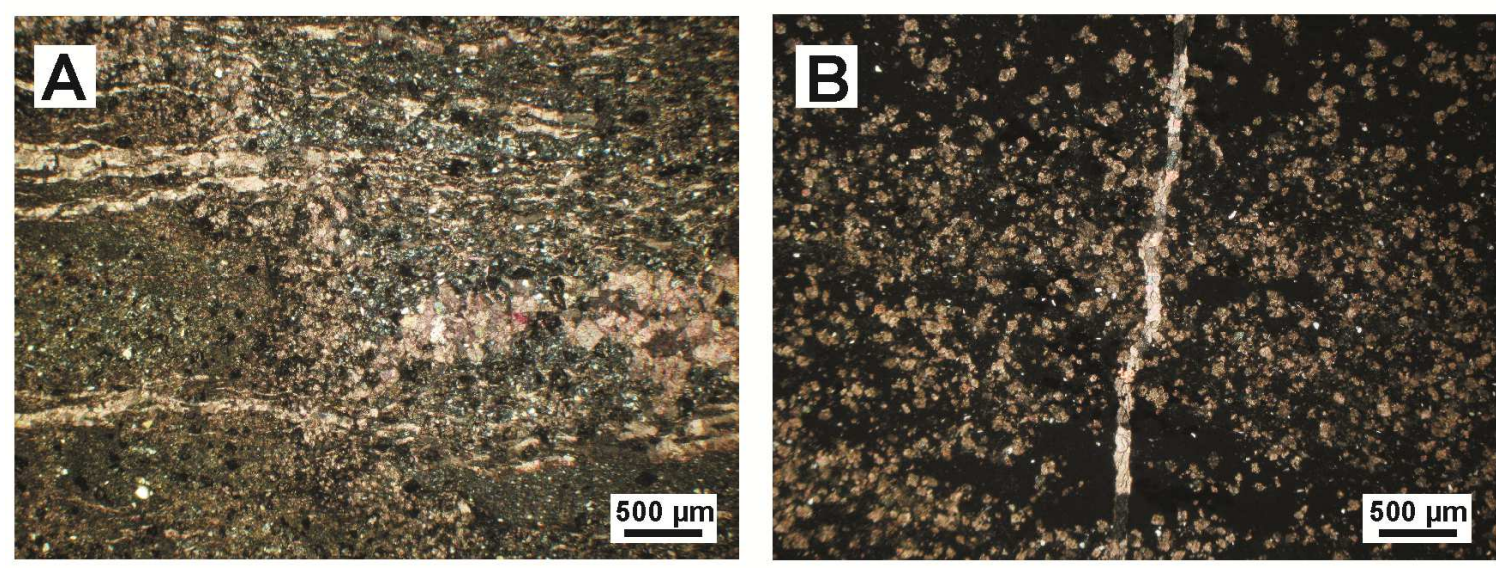

Figura 37. A e B) Veios horizontais (lâmina JZ-05D) e verticais de calcita (lâmina JZ05C) seccionam cristais romboédricos de calcita. Imagens sob polarizadores cruzados.

\subsubsection{Barita - $\mathrm{BaSO}_{4}$ e celestita com bário - $(\mathrm{Sr}, \mathrm{Ba}) \mathrm{SO}_{4}$}

A barita foi observada em cavidades das fácies chert nodular brechado e grainstone peloidal nas regiões de Jacarezinho e Joaquim Távora (PR). A barita também ocorre em fácies de calcário recristalizado principalmente por cristais de calcita e de zeólita. A barita ocorre como cristais anédricos ou euédricos. Os cristais têm comprimento de 10 a $30 \mu \mathrm{m}$, quando ocorrem em agregados, e de 300 a $500 \mu \mathrm{m}$, quando ocorre como cristal isolado. Em lâmina petrográfica, a barita se apresenta como cristais incolores de relevo alto e baixa birrefringência presentes no interior de cavidades de dissolução. Microfraturas de calcita com 10 ou $20 \mu \mathrm{m}$ de espessura seccionam as cavidades da fácies chert nodular e os cristais de barita. As figuras 38 e 39 apresentam as diversas formas de ocorrência da barita. 

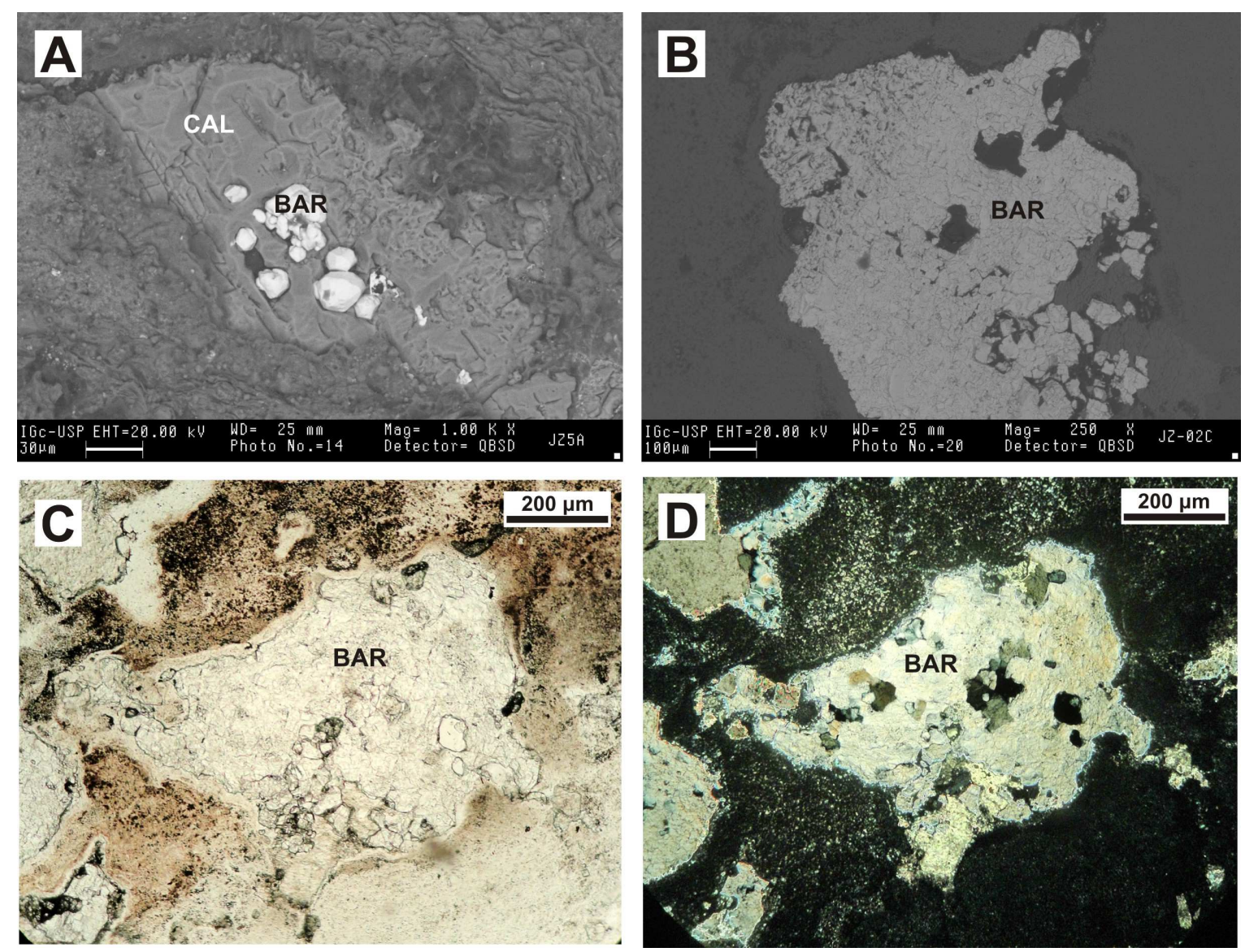

Figura 38. A) Cristais de barita (BAR) euédricos eqüidimensionais englobados por cristal de calcita blocosa (CAL), em cavidade de chert. Lâminas JZ-05A. Imagem formada por elétrons retro-espalhados; B) Agregados de cristais anédricos de barita (BAR) em cavidade de chert. Lâmina JZ-02C. Imagem formada por elétrons retroespalhados; C) Barita incolor e de relevo alto. Imagem sob polarizadores paralelos; D) Barita com birrefringência de $1^{\underline{a}}$ ordem. Imagem sob polarizadores cruzados. Lâmina JZ-02C. 

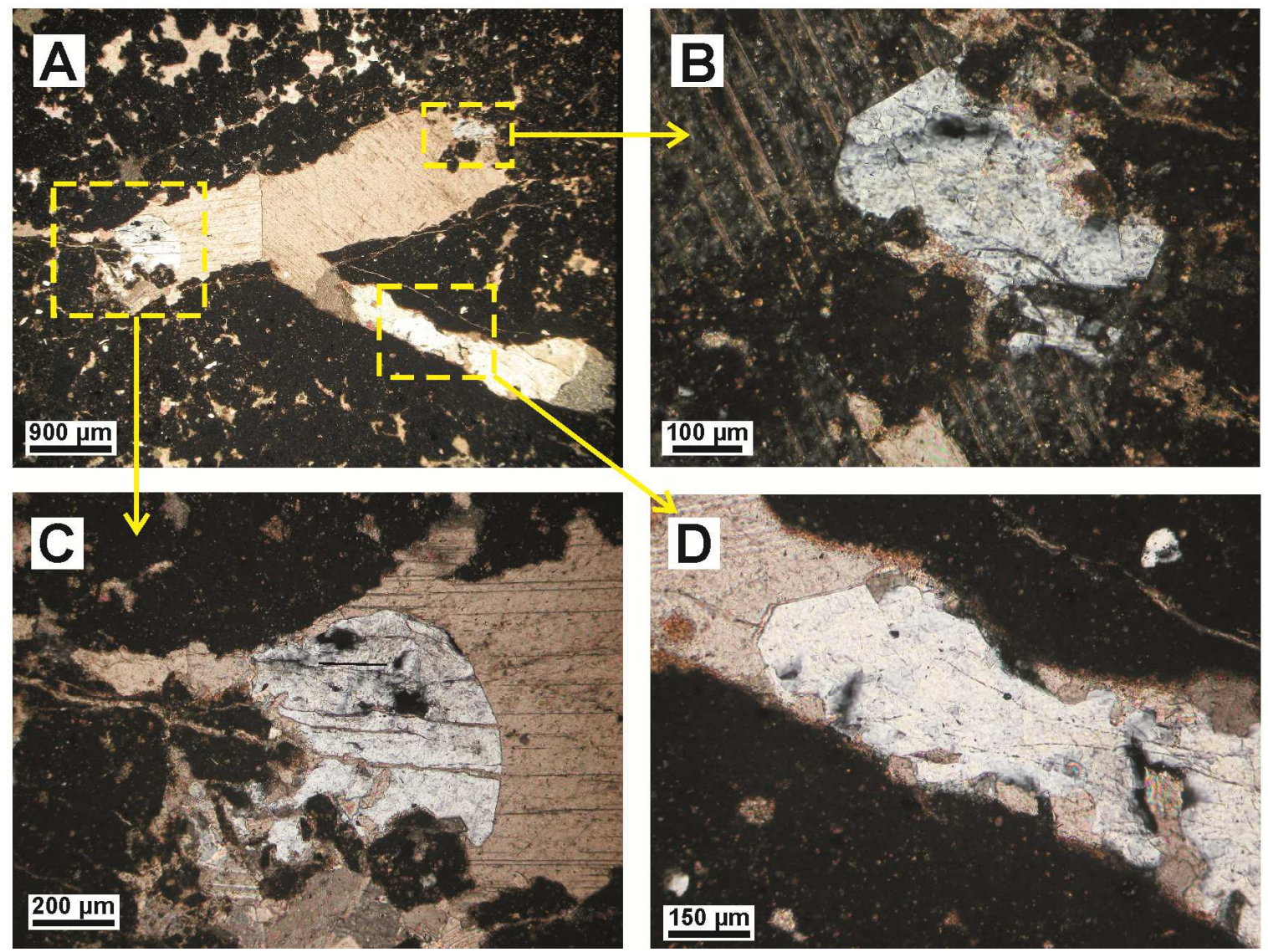

Figura 39. A) Cristais de barita envoltos por calcita blocosa em cavidade de dissolução da fácies grainstone peloidal; B, C e D) Modo de ocorrência em detalhe dos cristais de barita. Notar veios de calcita que seccionam a barita e a calcita blocky (C). Lâmina JZ-07E. Imagens sob polarizadores cruzados.

Em análise por EDS, verificou-se que a barita ocorre associada a outros compostos, dentre os quais se destacam a calcita, o quartzo, aluminossilicatos de sódio e de cálcio (e de potássio ?), óxidos de ferro e manganês e sulfato de estrôncio e bário (Figura 40). Análises por difração de raios-X (Figura 41) em amostra de rocha total da fácies de calcário recristalizado indicaram que a fase composta por sulfato de estrôncio e bário equivale a celestita com bário (barian celestine - $\left.(\mathrm{Sr}, \mathrm{Ba}) \mathrm{SO}_{4}\right)$, o que explica a presença de quantidade significativa de Sr por análises de EDS. Nesta fácies a barita também ocorre associada à presença de cristais cúbicos menores que $1 \mu \mathrm{m}$, cuja composição por análise de EDS apresentou os elementos $\mathrm{Na}, \mathrm{Cl}, \mathrm{Ca}, \mathrm{K}, \mathrm{Na}, \mathrm{Si}, \mathrm{S}$ (Figura 42). O formato cúbico desses cristais pode indicar possível presença de halita $(\mathrm{NaCl})$ ou de cloreto de sódio e potássio (silvinita?). Os outros elementos detectados ( $\mathrm{Ca}, \mathrm{Si}, \mathrm{S}$ e O) podem corresponder à matriz na qual esses cristais estão dispersos (calcita, sílica e barita), uma vez que o feixe de elétrons possui diâmetro ( $1 \mu \mathrm{m})$ similar ao cristal analisado. A barita também está associada à ocorrência de zeólita (analcima) e pirita (Figura 43). O preenchimento das cavidades ora por barita, ora por 
calcita espática ou por ambos minerais, sugere que os fluidos que originaram a precipitação desses minerais foram contemporâneos.
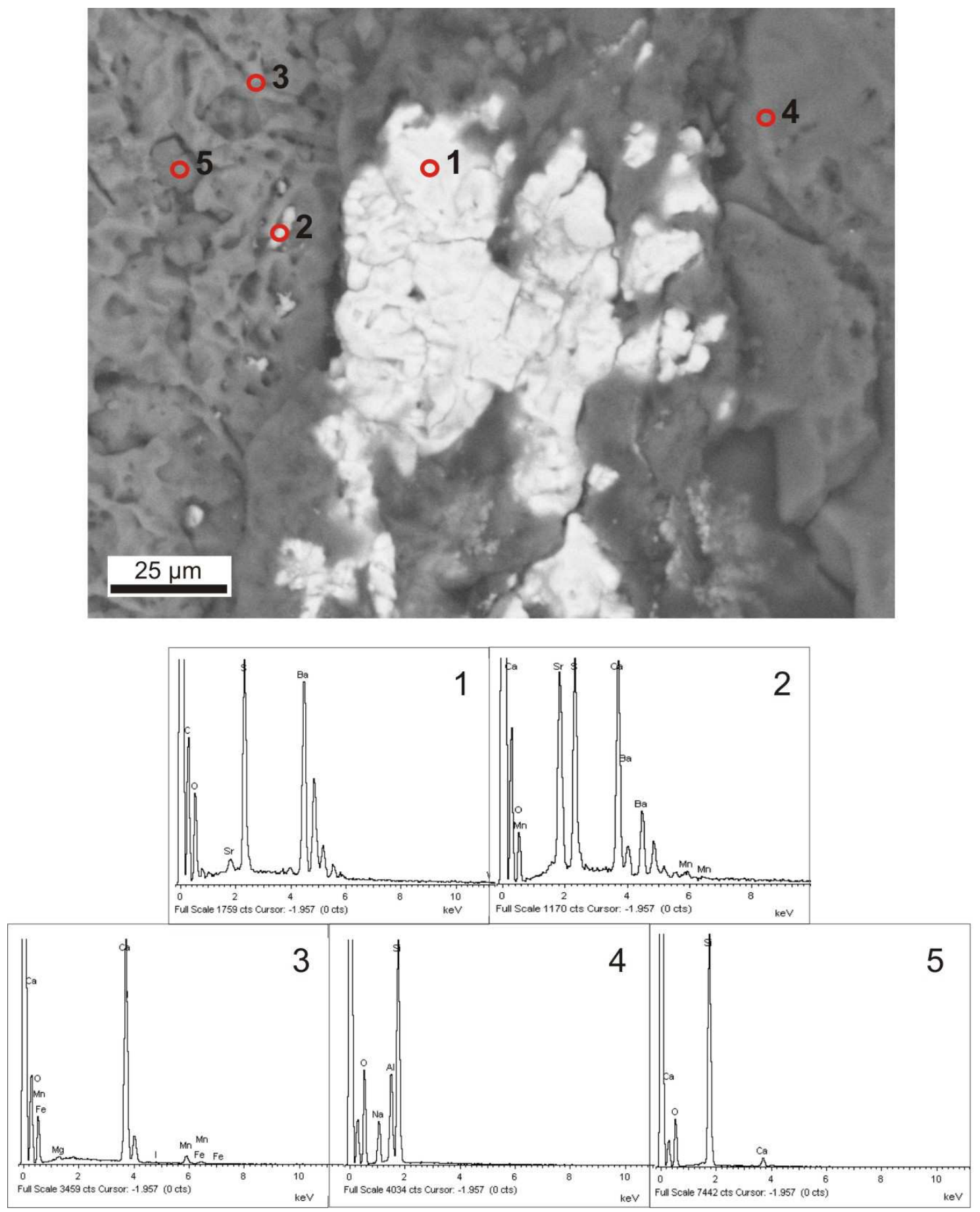

Figura 40. A) Barita com estrôncio ou celestita com bário (ponto 1); B) Celestita com bário (ponto 2); C) Calcita associada a prováveis óxidos de ferro e manganês (ponto 3); D) aluminossilicato de sódio (analcima) (ponto 4); E) Cristal de quartzo euédrico (ponto 5). Imagem formada por elétrons retro-espalhados (detector QBSD, condições: $\mathrm{EHT}=20,00 \mathrm{kV}, \mathrm{WD}=25 \mathrm{~mm}, \mathrm{Mag}=3000 \mathrm{x}$ ). Amostra JZ-13C. 


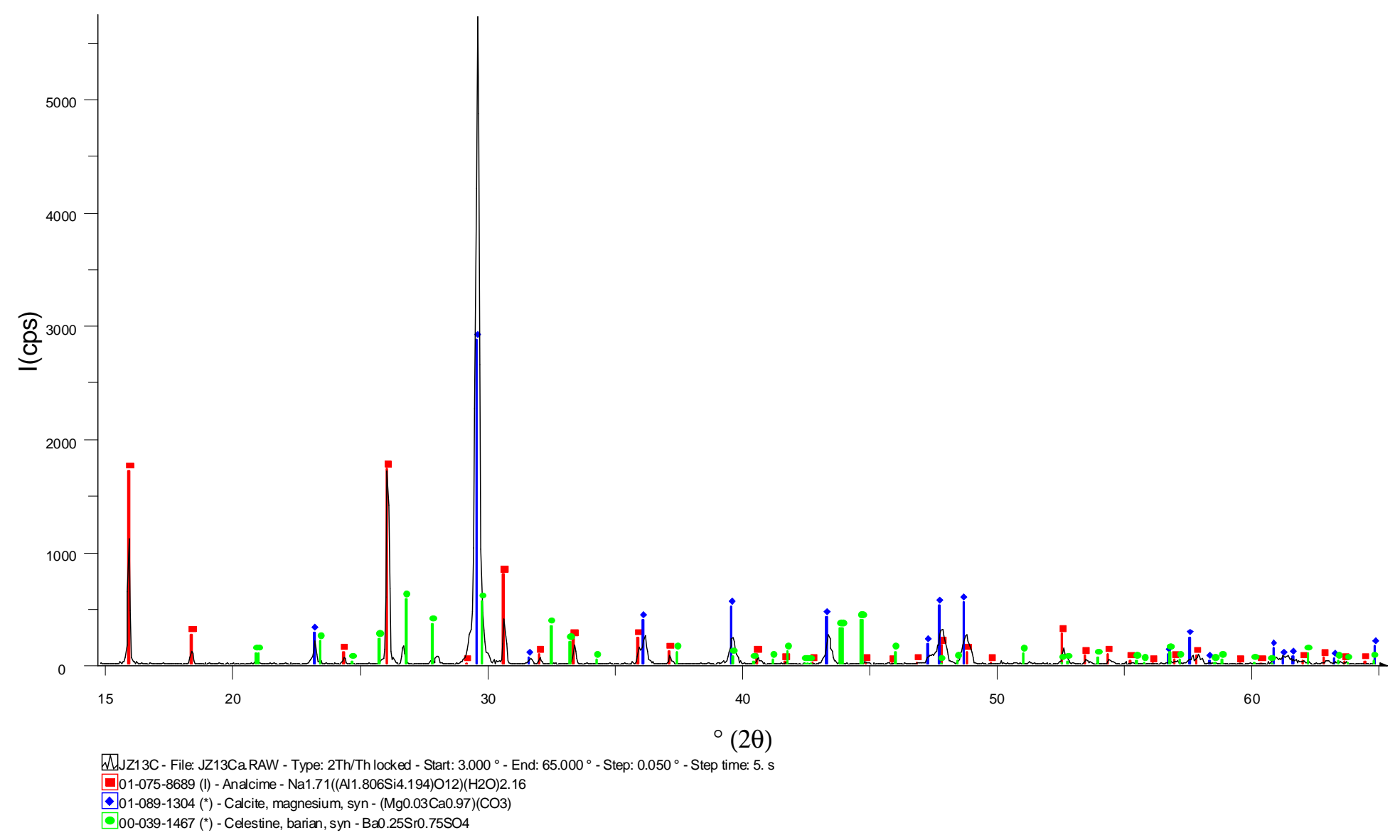

Figura 41. Difratograma de raios-x indica presença de celestita com bário (barian celestine). Amostra JZ-13C. 

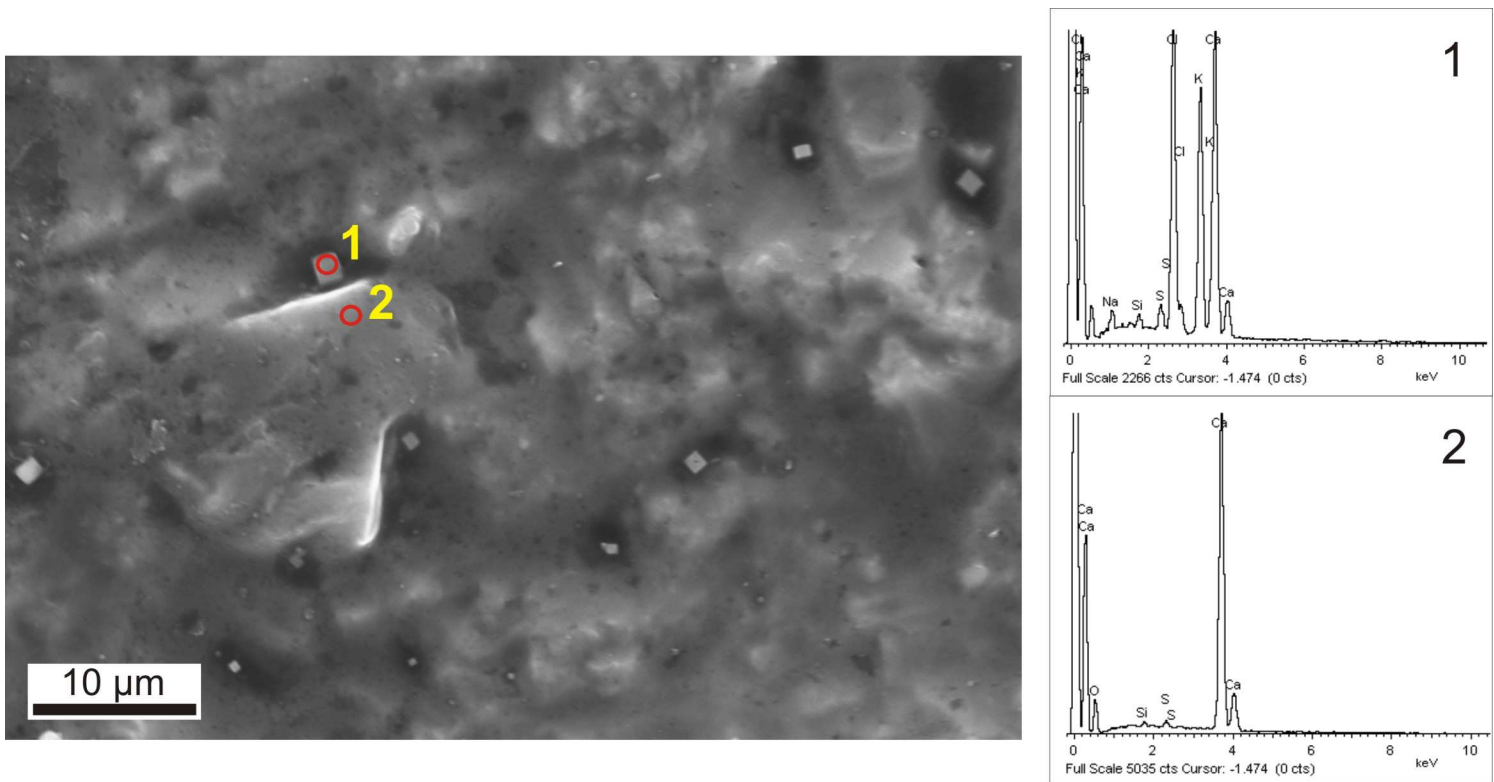

Figura 42. Imagem formada por elétrons secundários. Cristais cúbicos menores que 1 $\mu \mathrm{m}$ indicam possível presença de halita $(\mathrm{NaCl})$ e/ou silvinita $(\mathrm{KCl})$ (ponto 1) em matriz de calcita (ponto 2). Amostra JZ-13C.
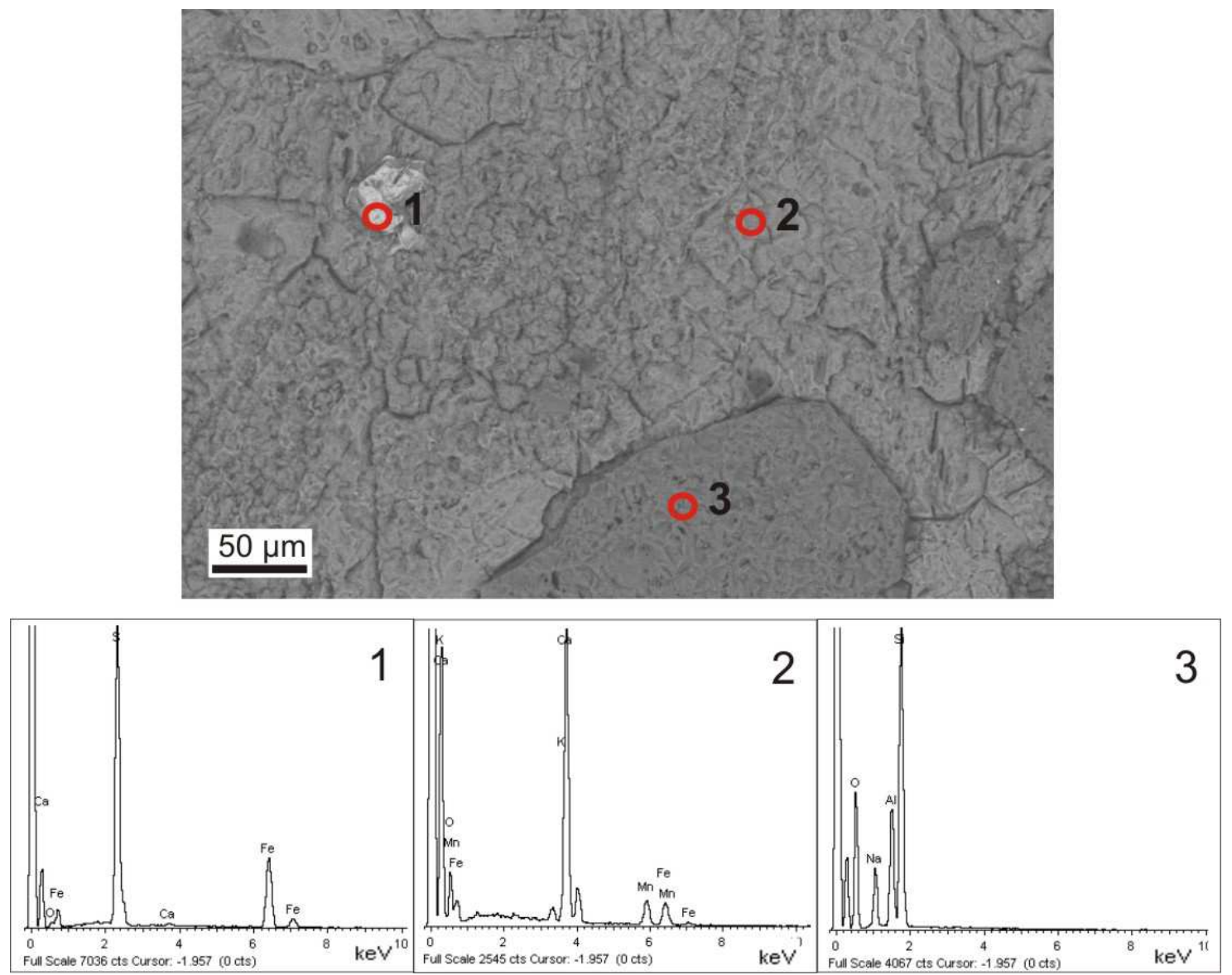

Figura 43. Pirita (ponto 1) dispersa em matriz formada por cristais de calcita (ponto 2). Cristal de analcima (ponto 3). Imagem formada por elétrons retro-espalhados (detector QBSD, condições: EHT = 20,00 kV, WD = 25 mm, Mag= 750 x). Amostra JZ-13C. 


\subsubsection{Zeólita (analcima - $\mathrm{Na}_{2}\left(\mathrm{Al}_{2} \mathrm{Si}_{4} \mathrm{O}_{12}\right) \cdot 2 \mathrm{H}_{2} \mathrm{O}$ )}

A analcima é um mineral do grupo das zeólitas e ocorre em calcário totalmente recristalizado, na região localizada entre Santo Antonio da Platina e Joaquim Távora. $\mathrm{Na}$ microscopia óptica apresenta-se euédrica com arestas arredondadas, eqüidimensional e incolor, embora também apareça em cor marrom claro, devido presença de inclusões escuras (Figura 44). Comumente cristais de calcita espática ocorrem envolvendo os cristais de analcima. A analcima também ocorre associada à ocorrência de barita, que é mais localizada. A rocha também é composta por alguns cristais de quartzo e raros feldspatos. A analcima foi identificada pelas análises de difratometria de raios-X e de EDS ( $\mathrm{Na}, \mathrm{Al}$ e $\mathrm{Si}$ ) (figuras 45 e 46).
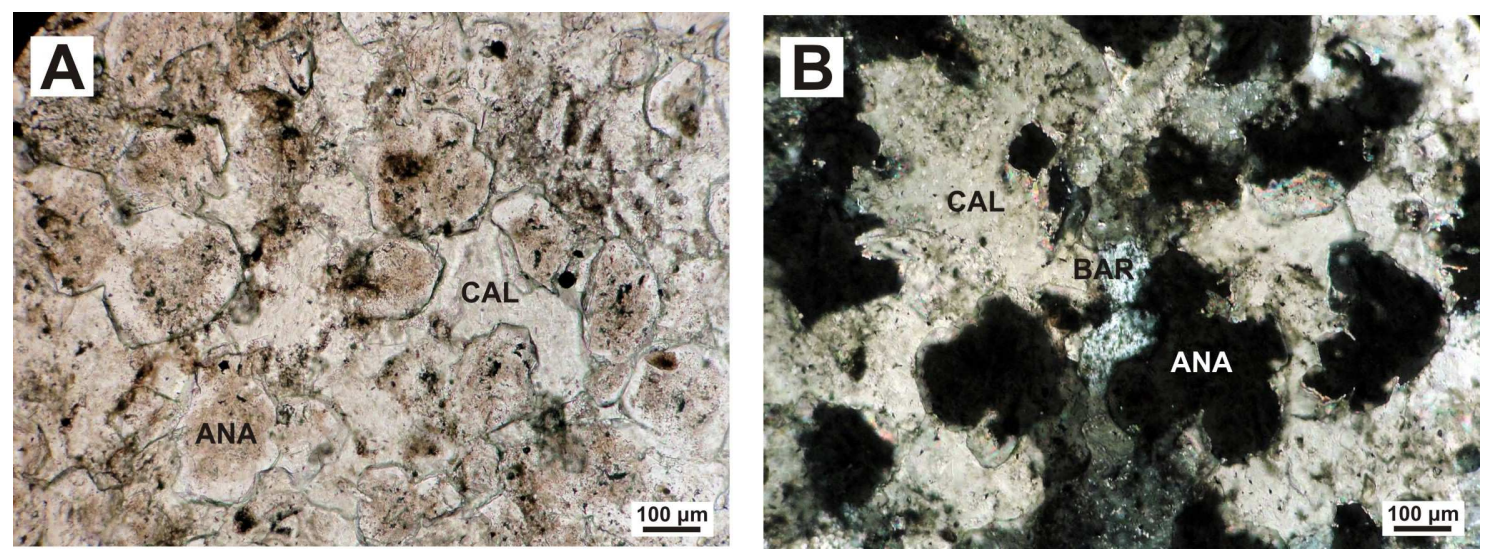

Figura 44. A) Analcima (ANA) com zoneamento dado pela cor marrom claro no núcleo (presença de inclusões) e borda incolor, sob polarizadores paralelos; B) Analcima isotrópica (ANA) e barita (BAR), envolvidas por cristais de calcita espática (CAL). Lâmina JZ-13C, sob polarizadores cruzados.

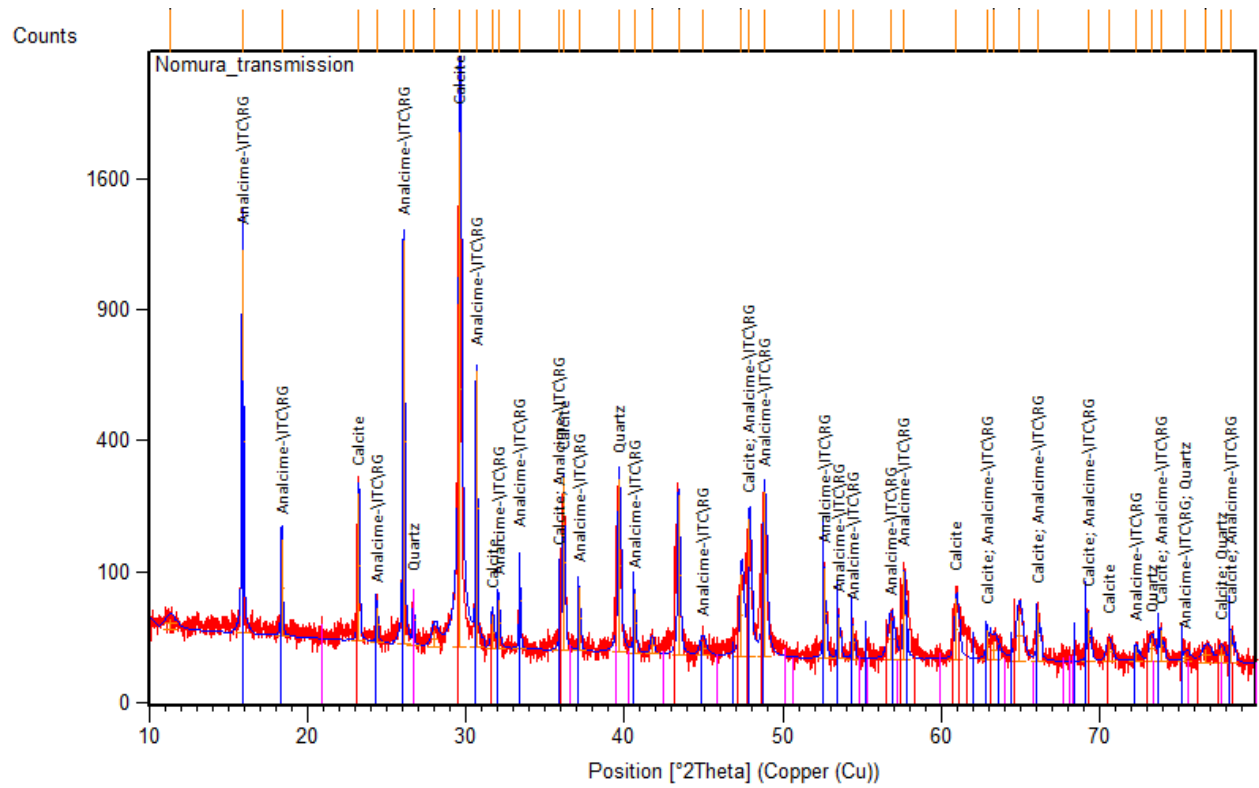

Figura 45. Difratograma de raios- $X$ com a identificação dos picos correspondentes a analcima e a calcita. Amostra JZ-13C. 


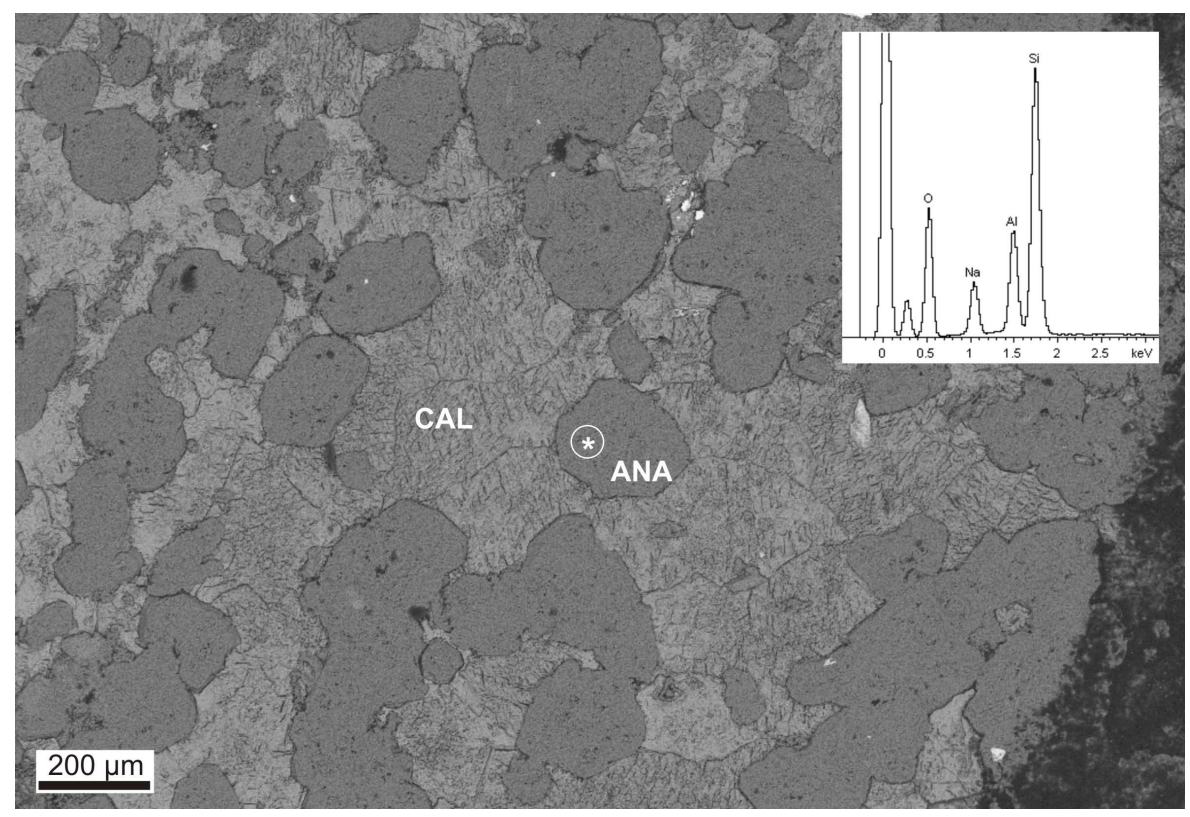

Figura 46. $\mathrm{O}$ asterisco indica o ponto analisado por EDS. A presença de $\mathrm{O}, \mathrm{Na}, \mathrm{Al}$ e $\mathrm{Si}$ confirma tratar-se de analcima. Amostra JZ-13C. Imagem formada por elétrons retroespalhados (detector QBSD, condições: $E H T=20,00 \mathrm{kV}, \mathrm{WD}=25 \mathrm{~mm}$, Mag= $150 \mathrm{x}$ ).

\subsubsection{Ilita-esmectita}

Argilominerais autigênicos com morfologia de folha rugosa sugerem a presença da esmectita que ocorre em poros da fácies chert nodular e da fácies de siltito arenoso com laminação heterolítica da Formação Teresina, respectivamente em-Jacarezinho e Taguaí, e em poros da fácies siltito roxo-acinzentados da Formação Corumbataí em Ipeúna. Apesar de esses argilominerais apresentarem morfologia típica da esmectita, sua composição química obtida por análises de EDS caracteriza possível mistura de ilita e esmectita. A reação ideal de transformação da esmectita em ilita é dada por (Hower et al., 1976):

$$
\text { esmectita }+\mathrm{Al}^{3+}+\mathrm{K}^{+} \rightarrow \text { ilita }+\mathrm{Si}^{4+} \text { (com perda de Fe e Mg) }
$$

A comparação das análises semi-quantitativas por EDS desses argilominerais com a reação ideal apresentada por Hower et al. (1976) demonstrou a presença do íon $\mathrm{K}^{+}$, característico da ilita, mas associado à presença de pequenas quantidades de $\mathrm{Ca}^{2+}$ e de quantidades relativamente elevadas de $\mathrm{Mg}^{2+}$ e $\mathrm{Fe}^{2+}$, característicos da esmectita. Isto justifica a interpretação dos argilominerais da Figura 47 como interestratificados de ilita-esmectita.

Estes interestratificados de ilita-esmectita se assemelham ao tipo honeycomblike descrito por Sant'anna et al. (2006) na Formação Rio Bonito (Bacia do Paraná). 

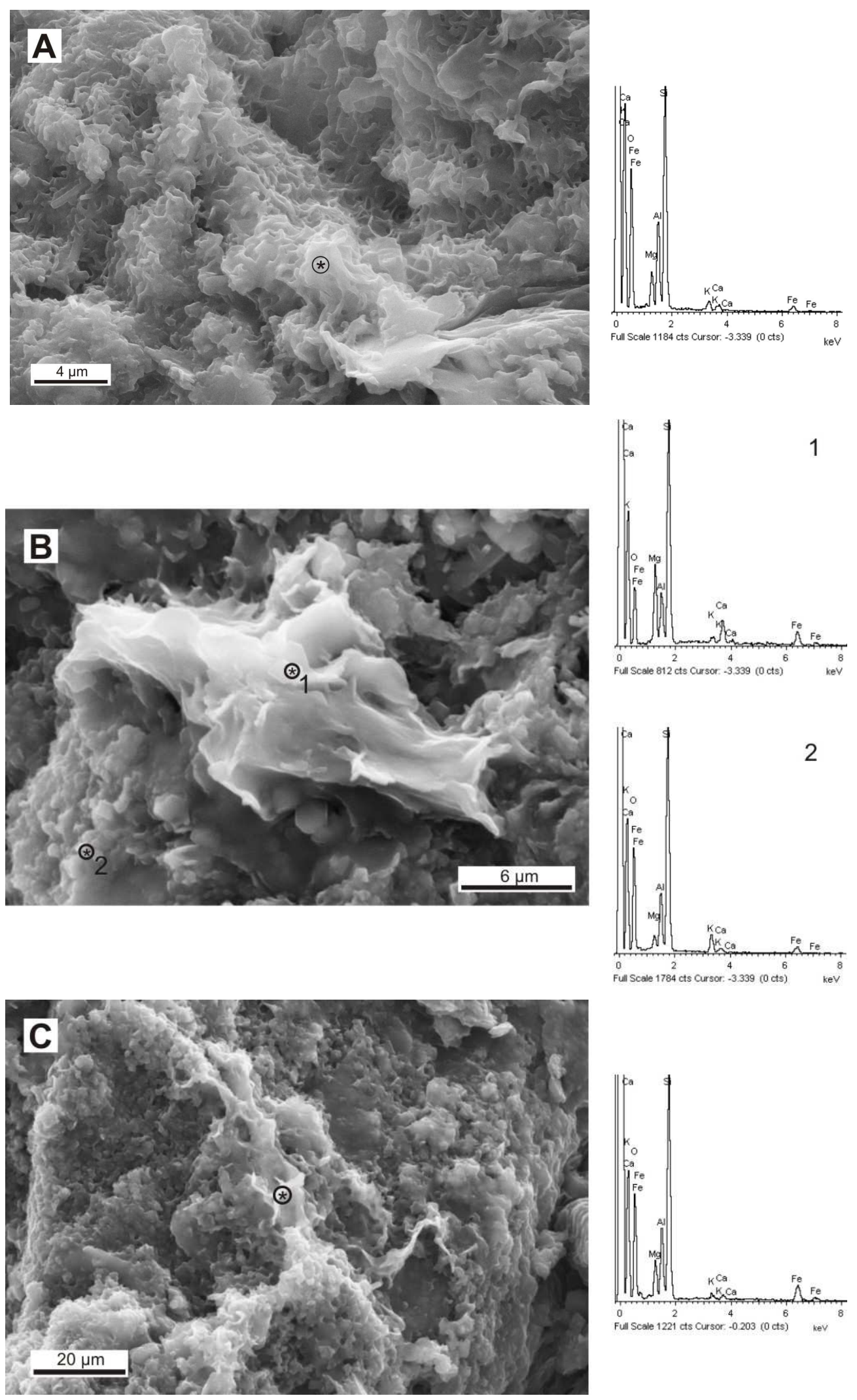

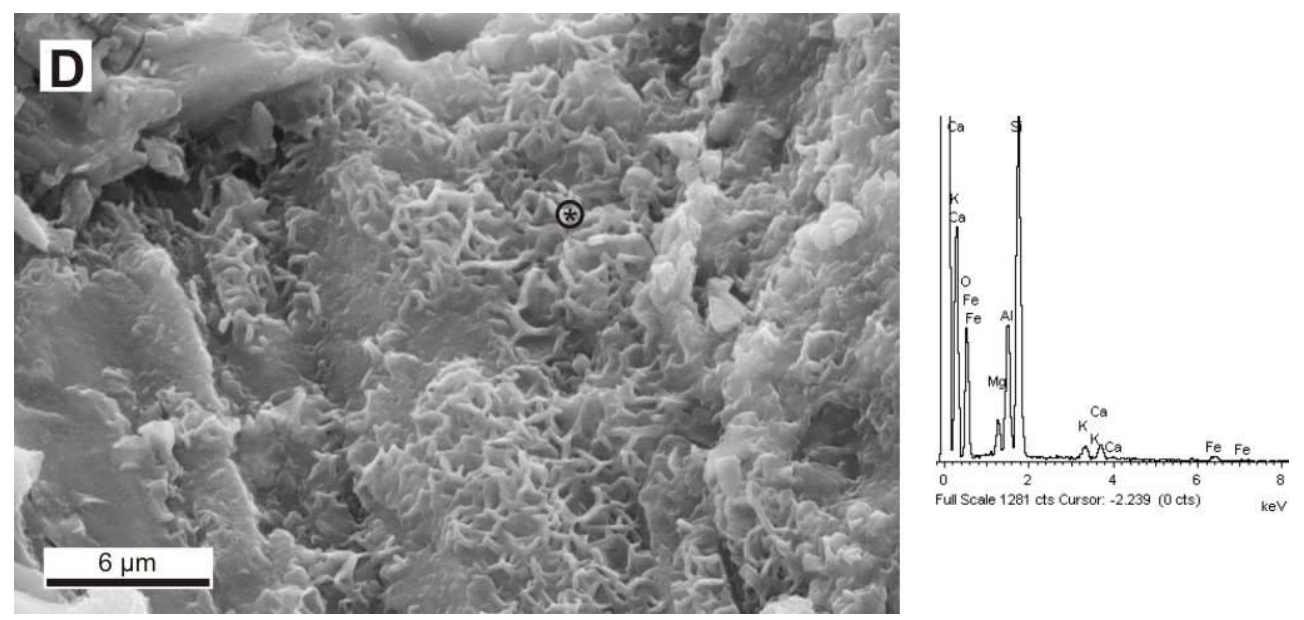

Figura 47. Interestratificados de ilita-esmectita e seus respectivos espectrogramas de análises químicas por EDS nos pontos indicados por asteriscos. A e B) amostra JZ05C; C) amostra MS-1; D) amostra TAGL. Imagens formadas por elétrons secundários (condições: $\mathrm{EHT}=20,00 \mathrm{kV}, \mathrm{WD}=18 \mathrm{~mm}$, com Mag $=10.000 \times$ em A, B e D e Mag = $5.000 \times \mathrm{em} \mathrm{C})$.

\subsubsection{Esmectita (saponita - $\mathrm{Ca}_{0,1} \mathrm{Na}_{0,2} \mathrm{Fe}_{1,1} \mathrm{MgAISi}{ }_{3,6} \mathrm{O}_{10}(\mathrm{OH})_{2}$ )}

Imagens por microscopia eletrônica de varredura e análises por EDS em argilominerais presentes em poros da fácies arenito muito fino siltoso da Formação Teresina em Fartura (amostra JZ-16A) indicaram a presença de esmectita (morfologia rugosa típica). Pela análise semi-quantitativa, através da obtenção das proporções relativas dos elementos detectados, sugere-se que esta esmectita trata-se do tipo trioctaédrica (saponita?), devido ao elevado teor de Fe e Mg. Não foi utilizada análise por DRX para identificação precisa do tipo de esmectita, devido à dificuldade para separar e diferenciar argilominerais detríticos e autigênicos. Esta amostra foi coletada em camada que estava em contato com dique básico associado ao evento magmático Serra Geral (Figura 12D). Os minerais do grupo da esmectita são formados por duas camadas de estruturas tetraédricas (dominadas por $\mathrm{Si}$ e $\mathrm{Al}$ ) recobertas por camadas octaédricas de hidróxido de metais. A esmectita dioctaédrica tem o sítio octaédrico ocupado principalmente por íons de $\mathrm{Al}^{3+}$ e $\mathrm{Fe}^{3+}$, enquanto que a trioctaédrica caracteriza-se por ocupar todo ou a maior parte deste sítio por íons de $\mathrm{Fe}^{2+}$ e $\mathrm{Mg}^{2+}$ (Güven, 1998). A montmorillonita (dioctaédrica - rica em Al) e a saponita (trioctaédrica - rica em $\mathrm{Fe}-\mathrm{Mg}$ ) são os tipos mais comuns entre esses dois tipos estruturais e composicionais de esmectita.

A saponita da Formação Teresina ocorre como cristais euédricos que recobrem cristais de quartzo autigênico e feldspato (Figura 48). Apesar da análise por MEV não fornecer dados de quantificação com precisão, a detectação dos elementos e as proporções relativas entre eles podem ser utilizados para fins de comparção. Assim, a 
proporção semi-quantitativa de $\mathrm{Ca}, \mathrm{Fe}, \mathrm{Mg}, \mathrm{Al}$ e $\mathrm{Si}$ para 10 átomos de $\mathrm{O}$ medida por EDS nesta esmectita foi 0,14Ca:0,84Fe:1,47Mg:0,88Al:2,9Si. Sabe-se que a transformação de saponita em clorita ocorre com aumento de temperatura. Segundo Chang et al. (1986), esta reação de cloritização com proporções estequiométricas, considerando-se o Al móvel, é dada por:

$$
\begin{gathered}
\mathrm{Ca}_{0,1} \mathrm{Na}_{0,2} \mathrm{Fe}_{1,1} \mathrm{MgAlSi}_{3,6} \mathrm{O}_{10}(\mathrm{OH})_{2} \text { (esmectita trioctaédrica: saponita)+ } \\
1.5 \mathrm{Fe}^{2+}+1,2 \mathrm{Mg}^{2+}+1,4 \mathrm{Al}^{3+}+7,6 \mathrm{H}_{2} \mathrm{O} \rightarrow \\
\mathrm{Fe}_{2,6} \mathrm{Mg}_{2,2} \mathrm{Al}_{2,4} \mathrm{Si}_{2,8} \mathrm{O}_{10}(\mathrm{OH})_{8} \text { (clorita) } \\
+0,1 \mathrm{Ca}^{2+}+0,2 \mathrm{Na}^{+}+0,8 \mathrm{SiO}_{2} \text { (quartzo) }+9,2 \mathrm{H}^{+}
\end{gathered}
$$

A comparação dos dados de análises químicas semi-quantitativas por EDS com a reação ideal de transformação da saponita em clorita sugere que as condições térmicas e/ou químicas não propiciaram a formação de clorita. Isto é interpretado pelo

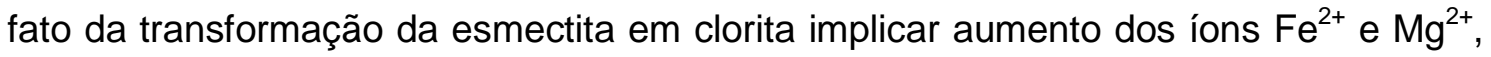
além da ausência de íons $\mathrm{Ca}^{2+}$, o que não foi observado nas análises semiquantitativas químicas das amostras estudadas (que detectou a presença de $\mathrm{Ca}$ ). Além disso, as imagens de alta resolução geradas pelo MEV corroboram a preservação da morfologia típica da esmectita.
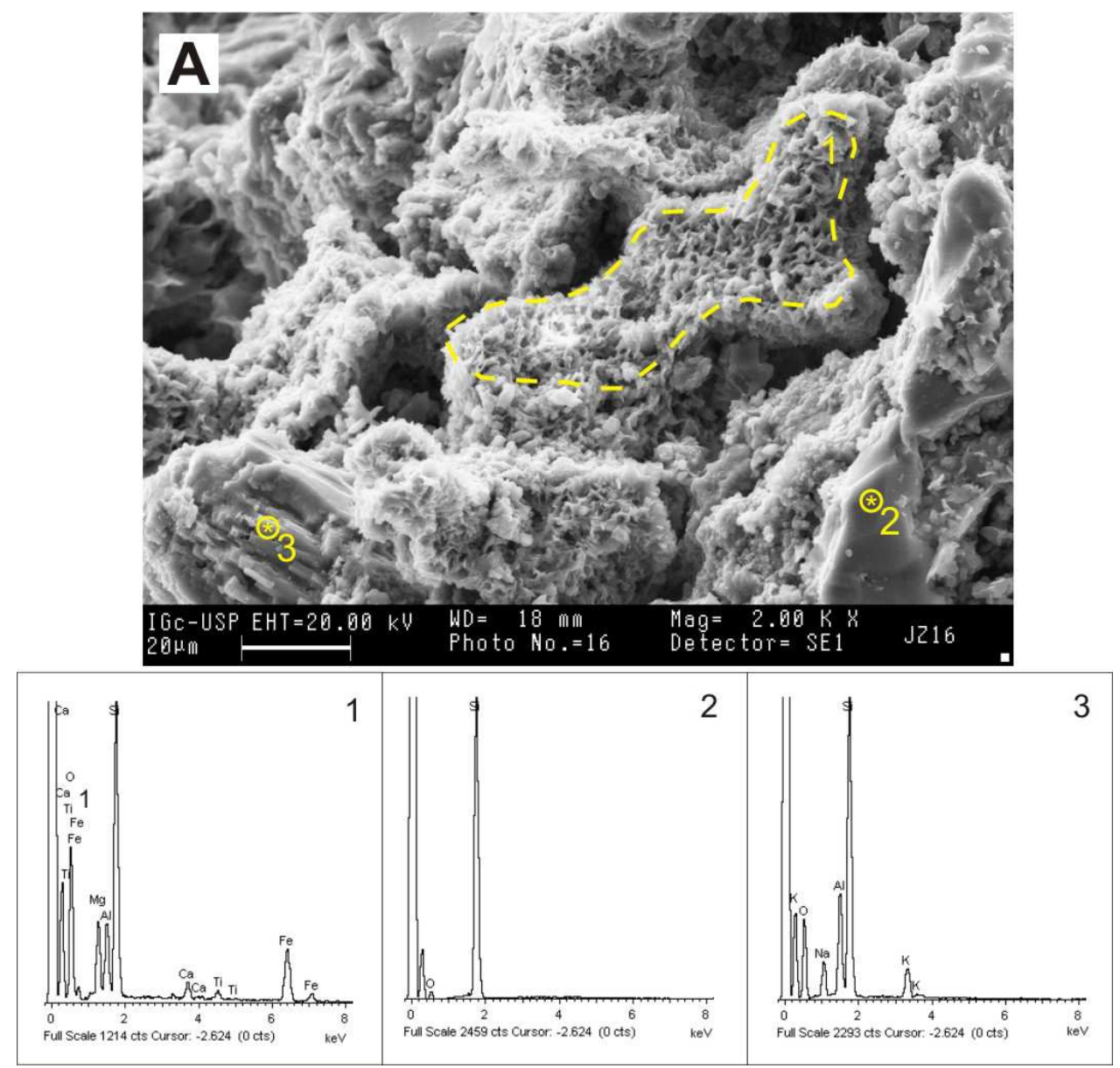

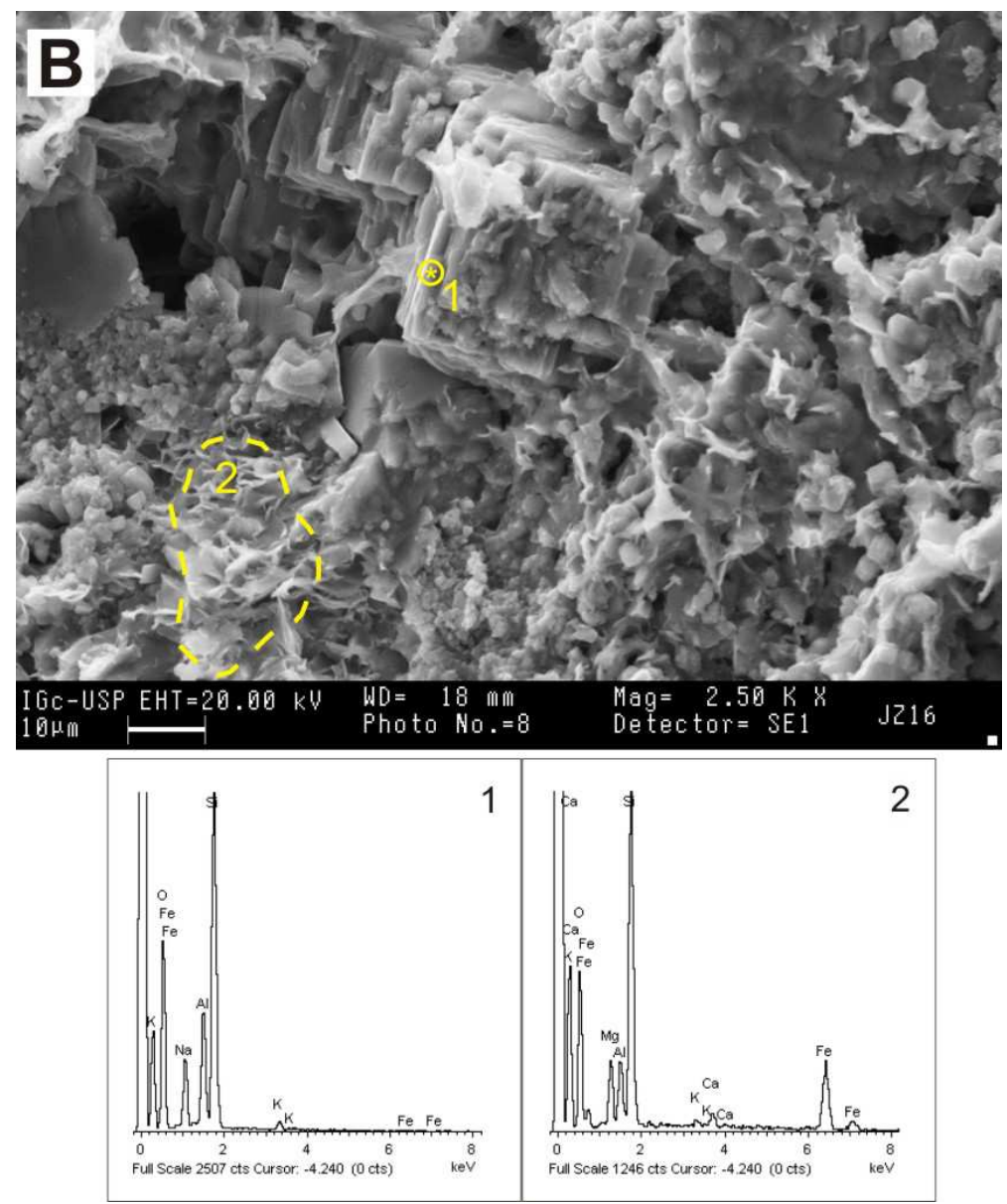

Figura 48. A) Análises por MEV-EDS identificaram saponita (ponto 1) em poros da fácies arenito muito fino siltoso. A saponita aparece sobre cristal de quartzo (ponto 2) e de albita (ponto 3); B) Saponita (ponto 2) sobre cristal de albita (ponto 1). Notar presença de cálcio nos pontos identificados como saponita. Amostra JZ-16A. Imagem formada por elétrons secundários.

\subsubsection{Betume sólido}

O betume identificado na Formação Teresina em Taguaí ocorre como veios ao longo de fraturas subverticais, de direção NW a NNW, com $1 \mathrm{~mm}$ a $1 \mathrm{~cm}$ de espessura, que cortam siltitos com laminação heterolítica. Também ocorre impregnado nos intervalos arenosos da fácies siltito arenoso com laminação heterolítica e nos veios horizontais de calcita (veios beef). Nos planos de fratura onde o betume está impregnado ocorre halo de alteração na cor esverdeada, além da ocorrência local de cristais de calcita espática, com estrias sugestivas de movimentação dos planos de fratura (slickenside). Na fácies siltito arenoso com laminação heterolítica, o betume preenche rede de fraturas $(<1 \mathrm{~mm}$ de espessura) sugestiva de brecha gerada por fraturamento hidráulico. As fraturas mais espessas apresentam clastos de siltito $(<0,3$ $\mathrm{mm}$ ) em matriz de betume. A Figura 49 apresenta os principais modos de ocorrência do betume em escala macroscópica. 

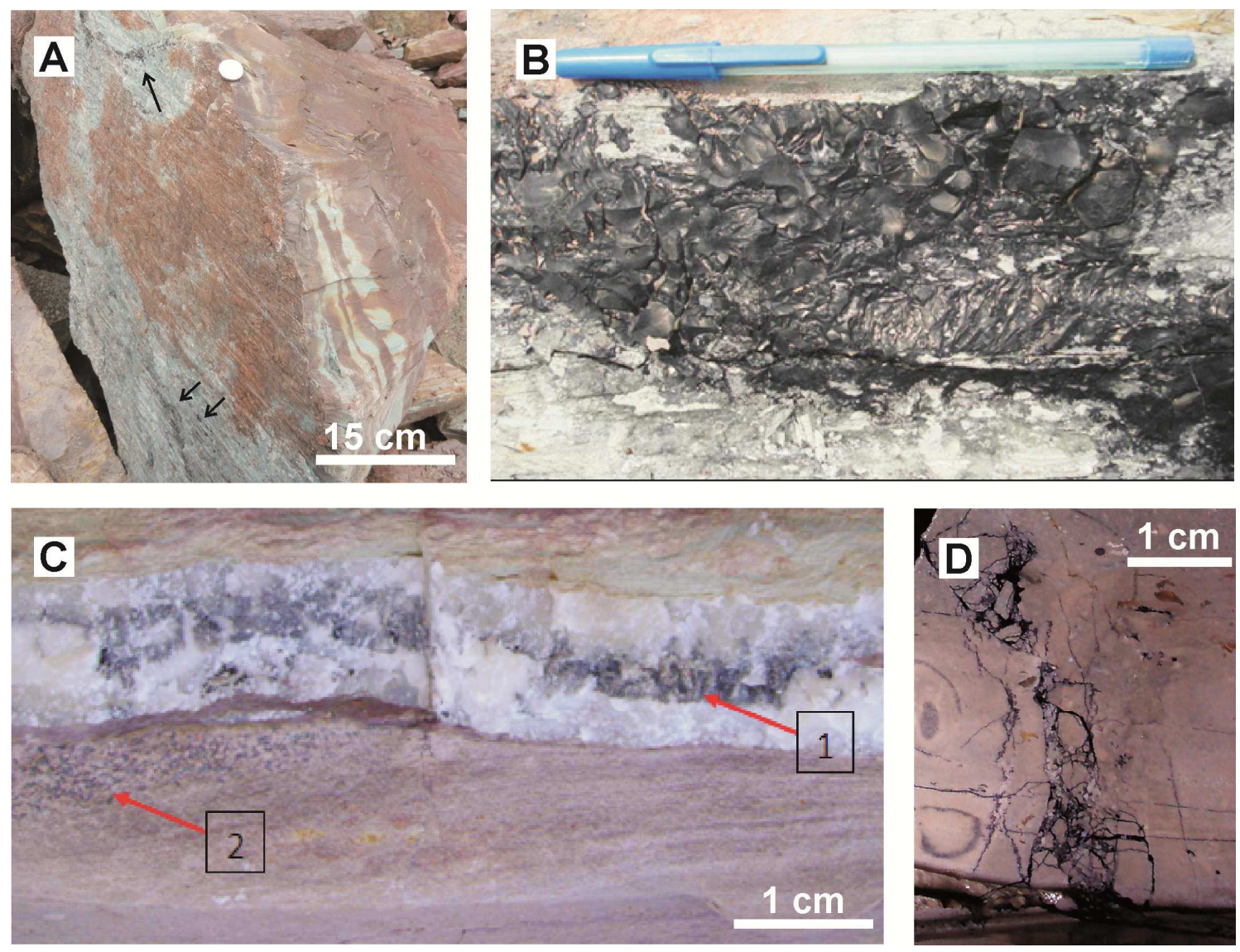

Figura 49. A) Halo de alteração em cor esverdeada adjacente ao plano de fratura de siltito com laminação heterolítica. As setas indicam o betume. Notar estrias em crostas de calcita espática (slickenside); B) Detalhe da ocorrência de betume no plano de fratura do siltito com laminação heterolítica; C) Veio de calcita horizontal (veio beef) com poros preenchidos por betume (seta 1). Os poros dos níveis arenosos do siltito com laminação heterolítica também estão preenchidos por betume (seta 2); D) Betume em fraturas verticais milimétricas em siltito com laminação heterolítica.

Observa-se que nos veios horizontais de calcita (beef), o betume ocorre em porosidade intercristalina (Figura 50) de cristais eqüidimensionais de calcita dispostos em mosaico. Em outros casos, a calcita forma arranjos de cristais alongados em direção perpendicular às camadas. Neste caso, o preenchimento por betume acompanha a direção do eixo maior dos cristais (Figura 50B). A ocorrência de estilólito com poros preenchidos por betume foi verificada na porção intermediária dos veios beef (Figura 50C) no contato entre níveis formados por cristais de calcita fibrosos finos e grossos. Lâmina delgada de amostra de siltito arenoso brechado (Figura 50D) indicou que o betume preenche fraturas (sem direção preferencial) entre os fragmentos de siltito. $O$ arranjo dessas fraturas associadas ao preenchimento por betume podem evidenciar fraturamento por sobrepressão devido à geração e expulsão de hidrocarbonetos (migração primária). 

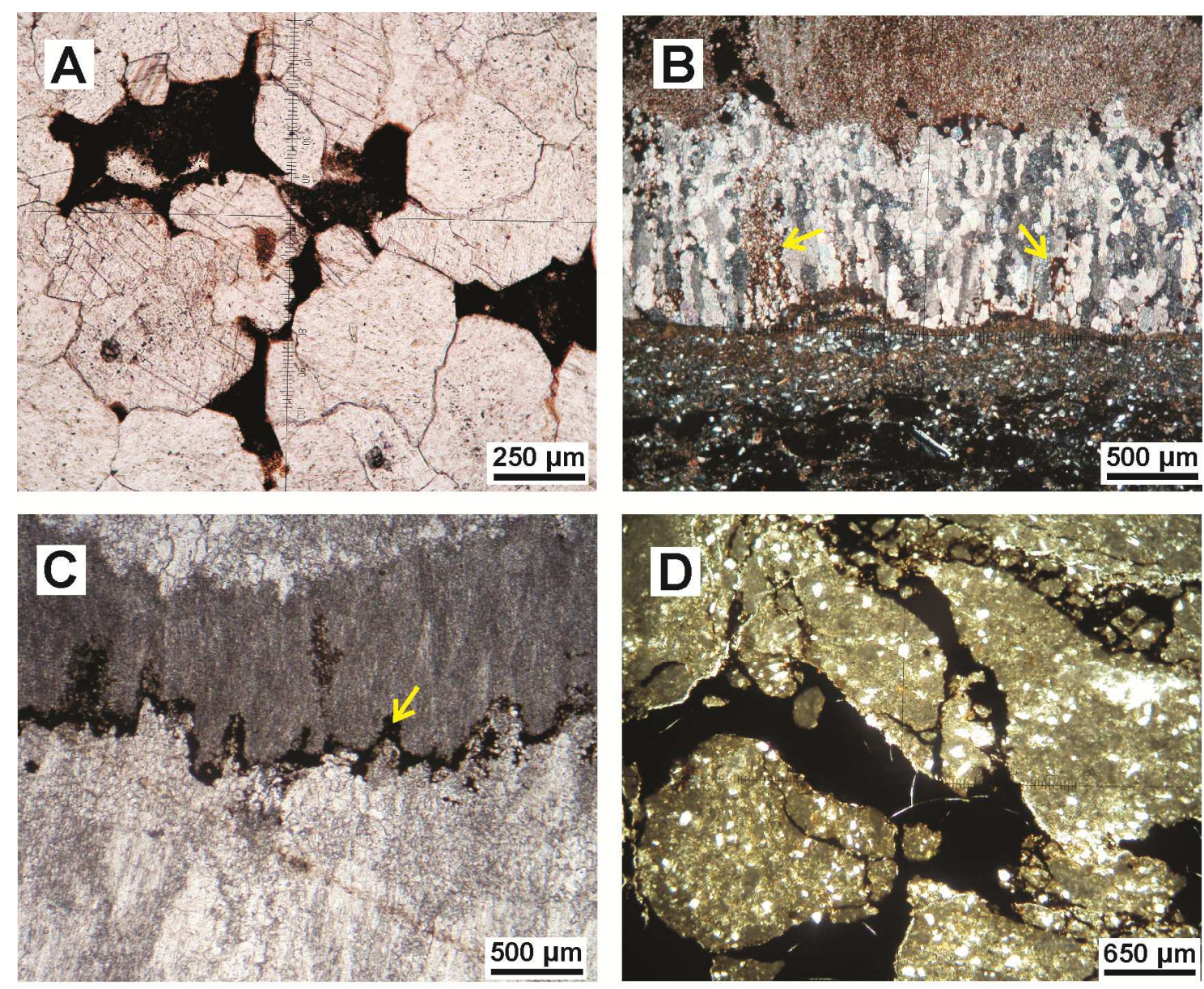

Figura 50. A) Betume em porosidade intercristalina de veios horizontais de calcita (beef). Imagem sob polarizadores paralelos; B) Porosidade intercristalina preenchida por betume que acompanha o eixo maior dos cristais de calcita (setas) em veio beef. Imagem sob polarizadores cruzados; C) Estilólito separa duas fases de calcita (fibrosa fina e grossa) e delimita zona de poros preenchidos por betume (seta). Imagem sob polarizadores paralelos; D) Fraturas preenchidas por betume em zona brechada de siltito com laminação heterolítica. Imagem sob polarizadores cruzados.

Análises por MEV nos intervalos arenosos da fácies de siltito com laminação heterolítica indicam que o betume preenche poros secundários do tipo vuggy. Estes poros são caracterizados por serem maiores que os grãos de quartzo, feldspato e micas do arcabouço. Isto sugere elevada dissolução dos grãos do arcabouço e formação de porosidade secundária em fase anterior à migração do betume. Análises por MEV em veios horizontais de calcita (beef) também confirmaram a presença de betume em estilólito, tal como observado por petrografia óptica, e demonstrou que os poros secundários preenchidos por betume concentram-se em bandas formadas por cristais de calcita de diferentes tamanhos. Cristais autigênicos de pirita e apatita estão associados ao betume dos veios de calcita horizontal. Os modos de ocorrência e a composição do betume nos veios de calcita e siltito com laminação heterolítica são apresentados nas imagens e espectrogramas EDS da Figura 51. 

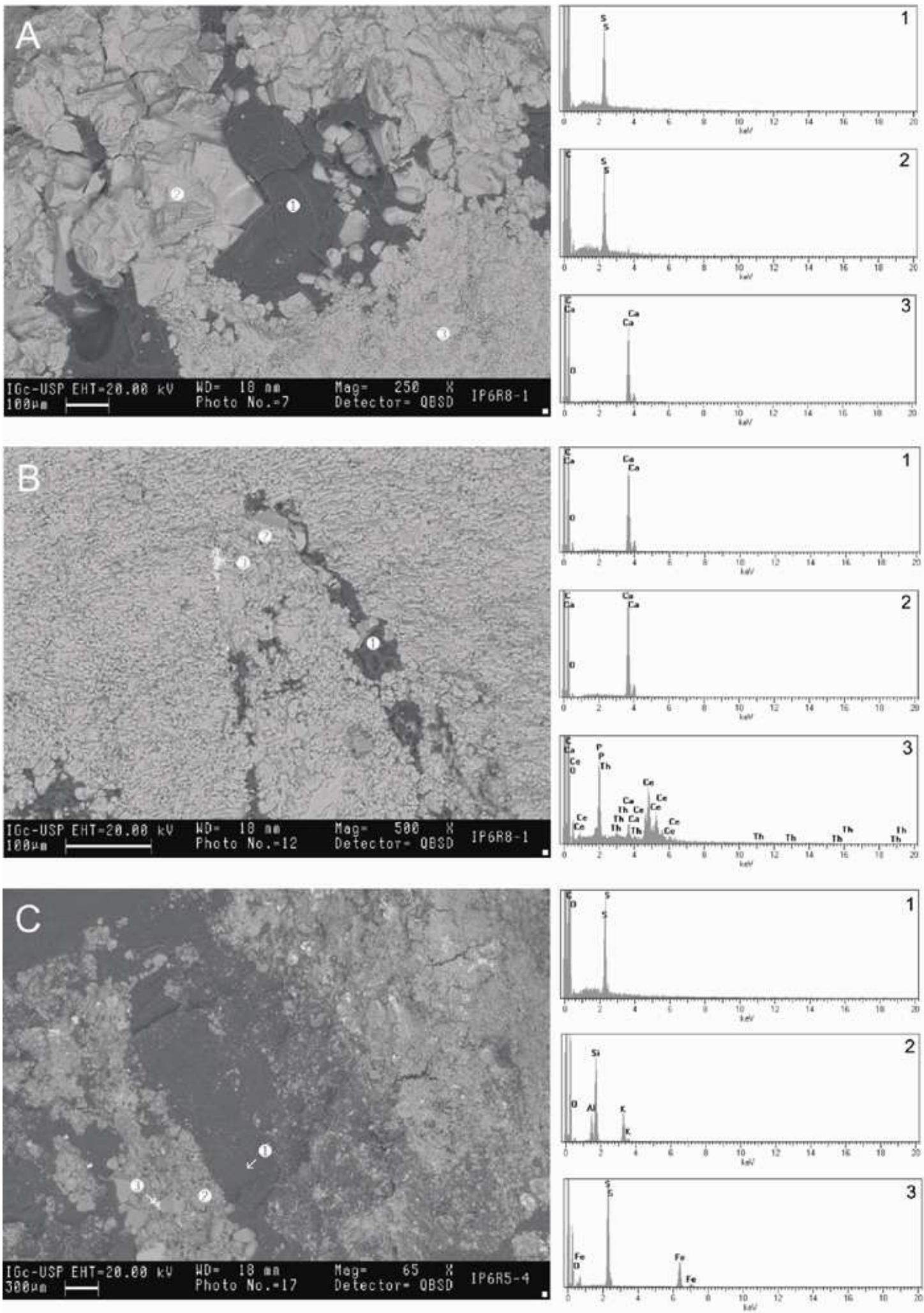

Figura 51. A) Betume em poros de veio horizontal de calcita (beef) da Formação Teresina. Notar duas bandas formadas por cristais de calcita de diferentes tamanhos. Análise por EDS indica quantidade significativa de enxofre (ponto 1); B) Betume ao longo de estilólito (ponto 1) em veio de calcita horizontal (ponto 2). Notar cristais de apatita associados à calcita (ponto 3); C) Fácies de siltito com laminação heterolítica (ponto 2) com poros secundários (tipo vuggy) preenchidos por betume (ponto 1). Notar cristais de pirita (ponto 3). 
O betume da Formação Teresina ocorre como um sólido compacto de cor preta, brilho vítreo, fratura conchoidal, dureza de 2 a 3 (escala Mohs) e densidade aproximada de $1,05 \mathrm{~g} / \mathrm{cm}^{3}$. Sob petrografia de luz ultravioleta, apresenta fluorescência fraca, mas contém inclusões com fluorescência alta nas cores azul ou amarela. Testes de aquecimento indicaram carbonificação (escurecimento) em temperaturas entre 330 e $350^{\circ} \mathrm{C}$ e sublimação entre 550 e $598^{\circ} \mathrm{C}$. A fusão antes da formação de vapor não foi observada. Análises de EDS demonstraram conteúdo significante de oxigênio e enxofre. Difratograma de raios-X apresentou um pico largo em $25^{\circ}\left(25^{\circ}=10-39^{\circ}\right)$ que é similar ao apresentado por antracito (Figura 52A). Espectrometria Raman apresentou alta fluorescência quando estimulada por laser HeNe e dois picos por volta de $1326-1340$ e $1588-1590 \mathrm{~cm}^{-1}$ (Figura 52B). Isto é similar a espectrogramas obtidos para betume por Zhang et al. (2007), que apresentou picos em $1360 \mathrm{~cm}^{-1}$ e $1620 \mathrm{~cm}^{-1}$.
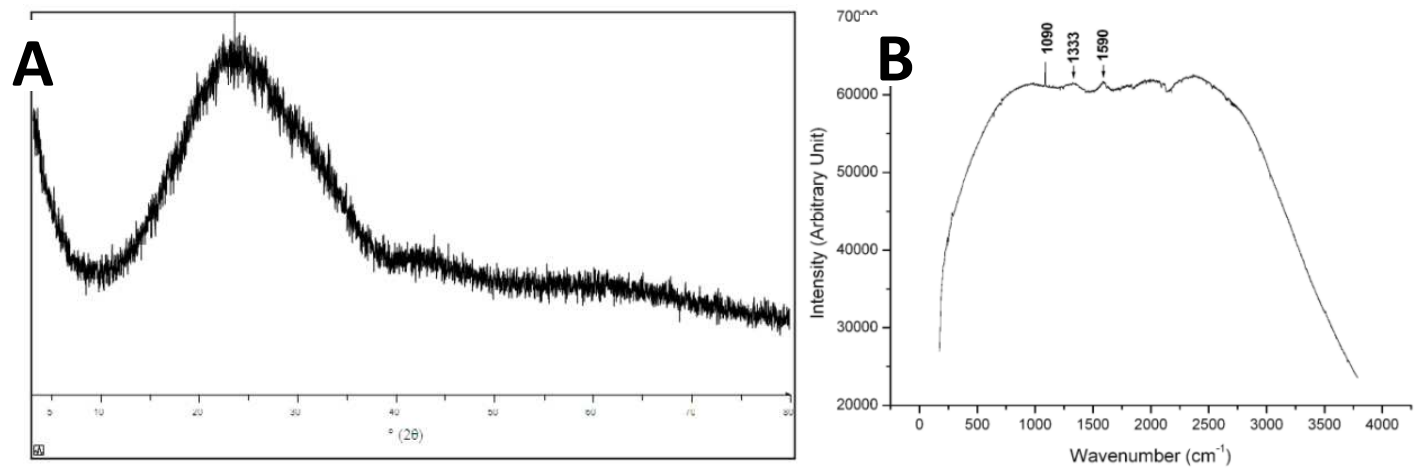

Figura 52. A) Difratograma de raios- $X$ do betume apresenta pico em $25^{\circ}$, similar ao apresentado por antracito; B) Espectograma Raman do betume.

\subsection{Inclusões Fluidas}

\subsubsection{Inclusões em veios de calcita horizontal (Taguaí, SP)}

Análises de inclusões fluidas foram realizadas em três veios horizontais de calcita da Formação Teresina na localidade de Taguaí (SP) (amostras TER-03, TER07 e TER-09). Dois veios estavam impregnados com betume (amostras TER-03 e TER-07).

As associações de inclusões fluidas nesses veios horizontais de calcita compreendem inclusões monofásicas e bifásicas aquosas claras. Algumas inclusões apresentam fases sólidas escuras ou incolores, que poderiam corresponder a minerais de saturação (daughter minerals), precipitados a partir do fluido após o aprisionamento, ou a minerais ocasionalmente aprisionados. Minerais de saturação devem apresentar proporções volumétricas semelhantes em inclusões fluidas 
cogenéticas enquanto que nos sólidos aprisionados ocasionalmente essas proporções são variáveis (Roedder 1984, Shepherd et al. 1985). Entretanto, o tamanho diminuto das fases sólidas observadas não permitiu uma estimativa segura das razões volumétricas. As inclusões monofásicas estão distribuídas no interior de todos os cristais de calcita. Inclusões bifásicas com morfologia de cristal negativo são mais comuns, embora inclusões alongadas ou de forma irregular também estejam presentes. A razão entre o volume da fase vapor e o volume total da inclusão $\left(\mathrm{V}_{\mathrm{VAP}} / \mathrm{V}_{\mathrm{IF}}\right)$ varia de 0,05 a 0,20 , com média ao redor de 0,10 . Muitas inclusões apresentam distribuição aleatória ao longo do cristal, mas predominam as alongadas e alinhadas na direção de maior alongamento dos cristais de calcita fibrosa. Neste caso, a orientação das inclusões é determinada pela direção de crescimento do cristal (Goldstein \& Reynolds, 1994) e são de origem primária. Algumas inclusões fluidas orientadas, dispostas aparentemente ao longo da direção de crescimento do cristal, parecem estar limitadas ao interior dos cristais, sem ultrapassar suas bordas, o que sugere origem pseudo-secundária. Entretanto, em alguns casos não pode ser descartada a origem secundária para as inclusões orientadas, devido à dificuldade em se observar as relações entre os limites dos cristais e a distribuição dessas inclusões. A Figura 53 apresenta as características das inclusões fluidas submetidas à microtermometria. Inclusões fluidas com feições indicativas de necking down ou leakage não foram medidas. A Figura 54 apresenta o sumário dos dados microtermométricos. As inclusões fluidas bifásicas dos veios horizontais de calcita apresentam temperaturas de homogeneização (TH) de 59 a $131^{\circ} \mathrm{C}$, com duas modas principais em $60-80^{\circ} \mathrm{C}$ e $100-120^{\circ} \mathrm{C}$, (amostra TER-03); 46 a $178^{\circ} \mathrm{C}$, moda entre 80 $100^{\circ} \mathrm{C}$ (amostra TER-07) e 43 a $286^{\circ} \mathrm{C}$ (amostra TER-09), com moda entre $60-80^{\circ} \mathrm{C}$. Apesar do registro de valores de até $286^{\circ} \mathrm{C}$, as maiores $\mathrm{TH}$ com significativo número de medidas em todas as amostras situaram-se ao redor de $130^{\circ} \mathrm{C}$. 

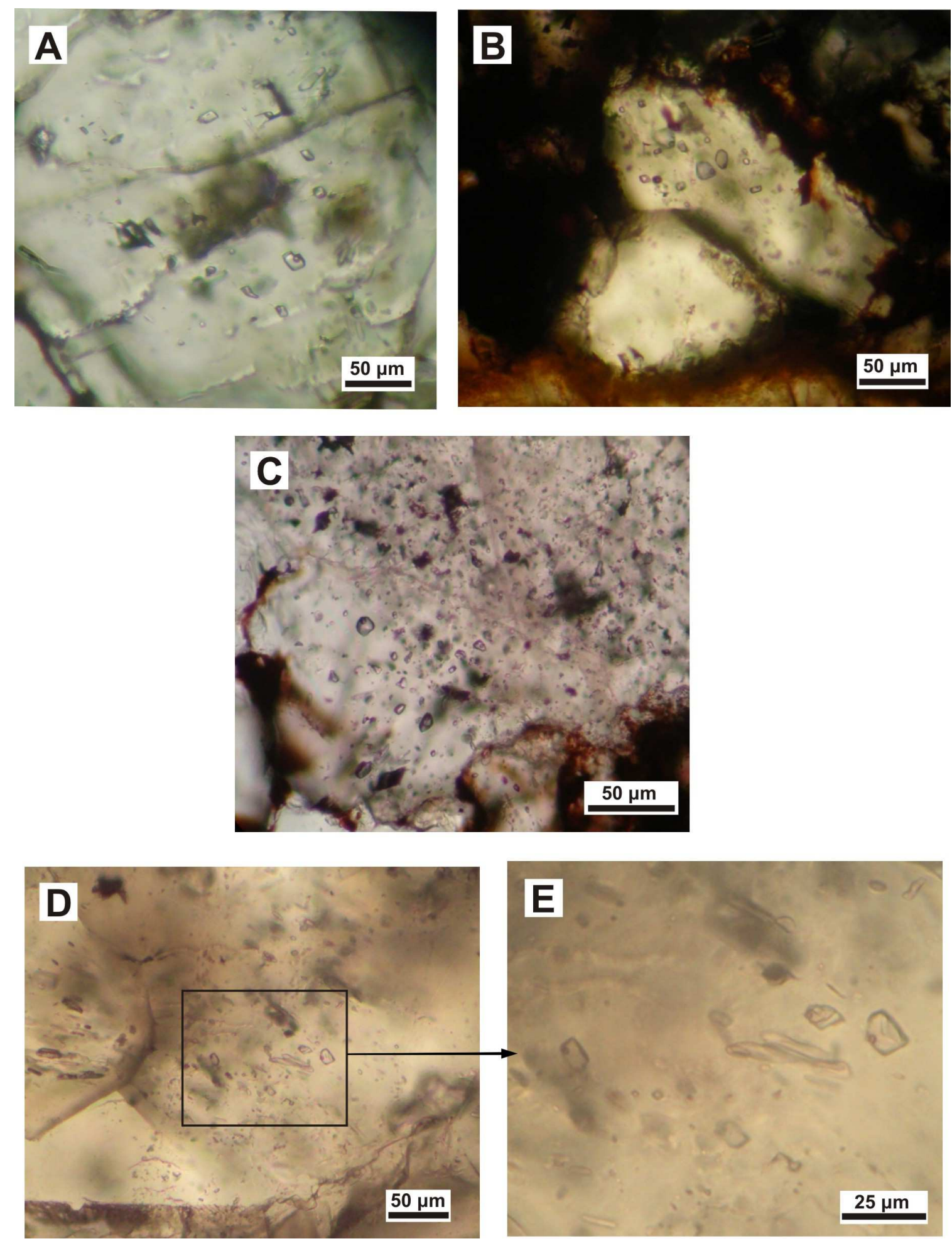

Figura 53. A e B) Inclusões fluidas bifásicas com morfologia de cristal negativo distribuídas aleatoriamente; C) Orientação de algumas inclusões fluidas bifásicas com morfologia de cristal negativo e outras mais irregulares com distribuição mais aleatória; D) Inclusões fluidas monofásicas alongadas coexistindo com bifásicas com morfologia de cristal negativo; E) Detalhe da imagem D 


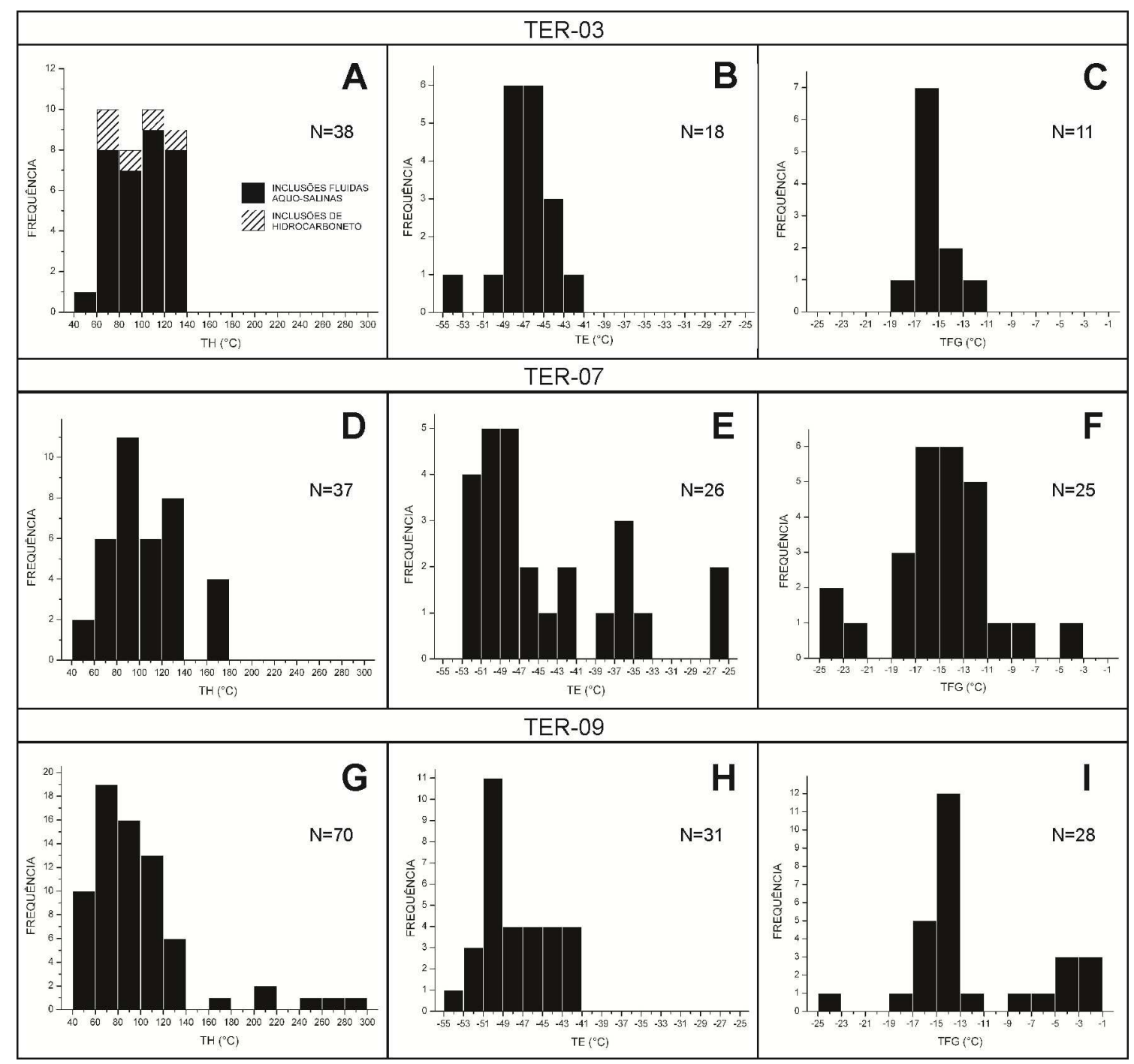

Figura 54. Distribuições de freqüência das temperaturas de homogeneização (TH), do ponto eutético (TE) e de fusão do gelo (TFG), medidas nas amostras de calcita TER03 (A, B e C), TER-07 (D, E e F) e TER-09 (G, H e I). Essas amostras correspondem a veios de calcita horizontais paralelos ao acamamento da Formação Teresina, em Taguaí.

Medidas de resfriamento foram realizadas em inclusões aquo-salinas. As temperaturas do ponto eutético (TE) nas inclusões dos veios TER-03 e TER-09 situaram-se no intervalo de $-54 \mathrm{a}-41^{\circ} \mathrm{C}$, enquanto que as inclusões nos cristais do veio TER-07 apresentaram um maior intervalo de TE, situado entre -53 e $-27^{\circ} \mathrm{C}$. Neste caso, abaixo de $-40^{\circ} \mathrm{C}$, mudanças sutis de textura da solução congelada levaram à incerteza na estimativa das temperaturas eutéticas. As temperaturas de fusão do gelo (TFG) variaram de $-25 \mathrm{a}-1^{\circ} \mathrm{C}$ (considerando-se em conjunto os veios TER-03, TER-07 e TER-09), com maior freqüência de valores entre -17 e $-13^{\circ} \mathrm{C}$. Essas temperaturas correspondem a salinidades de 2 a $26 \%$ em peso equivalente de $\mathrm{NaCl}$, com moda entre 17 e $21 \%$ em peso equivalente de $\mathrm{NaCl}$. Essses valores 
indicam a predominância de fluidos de alta salinidade. Contudo, a salinidade dos fluidos primários pode ser maior do que os valores estimados devido à possível presença de minerais de saturação (minerais filhas). Particularmente, as temperaturas de fusão do gelo no veio TER-03 variaram de -18 a $-11^{\circ} \mathrm{C}$, o que corresponde a fluidos de composição relativamente homogênea e de maior salinidade (16-22 \% em peso de $\mathrm{NaCl}$ equivalente). Uma maior variação das TFG caracteriza os veios TER-07 (de $25 \mathrm{a}-5^{\circ} \mathrm{C}$ ) e TER-09 (de $-24 \mathrm{a}-1,0^{\circ} \mathrm{C}$ ). Apesar da predominância de fluidos muito salinos, a variação de salinidade nesses veios é relativamente elevada.

Inclusões fluidas de hidrocarbonetos foram observadas em uma das amostras do veio horizontal de calcita impregnado por betume (amostra TER-03) e apresentaram valores de $\mathrm{TH}$ entre 60 e $140^{\circ} \mathrm{C}$, com moda entre 60 e $80^{\circ} \mathrm{C}$. A microscopia sob luz ultravioleta indica a presença de inclusões bifásicas com fluorescência azul, o que confirma o aprisionamento de hidrocarbonetos (Figura 55). Testes de esmagamento realizados em seções delgadas de fragmentos de calcita, com glicerina, demonstram o aparecimento e expansão de bolhas, o que denota a presença de gases sob pressão nas inclusões. Bolhas que se solubilizam em querosene apontam para a presença de hidrocarbonetos gasosos. Espectrograma Raman de uma inclusão bifásica apresentou fase vapor com picos em 2858, 2879, 2914 e $2936 \mathrm{~cm}^{-1}$, e fase líquida com picos em 2874, 2913 e $2937 \mathrm{~cm}^{-1}$ (Figura 56 AB). De acordo com Burke (2001), o uso da espectroscopia micro-Raman para identificar hidrocarbonetos é dificultado pois os mesmos apresentam alta fluorescência, principalmente os mais pesados. Contudo, Zhang et al. (2007) afirmam que a estrutura molecular e os grupos de base dos hidrocarbonetos afetam seu espectrograma Raman, possibilitando a discriminação de diferentes tipos de hidrocarbonetos . Para Zhang et al. (2007), picos Raman de 2700 a $2970 \mathrm{~cm}^{-1}$ são característicos de hidrocarbonetos saturados. Análises de outras inclusões bifásicas indicaram que, apesar do alto background do espectrograma Raman, podem ser observadas altas emissões nos intervalos $2900-3000 \mathrm{~cm}^{-1}$ e $3200-3500 \mathrm{~cm}^{-1}$, indicando, respectivamente, a presença de hidrocarbonetos e água (Figura 56C). Os espectrogramas Raman do cristal hospedeiro são caracterizados por picos da calcita $\left(1086,1436\right.$ e $\left.1749 \mathrm{~cm}^{-1}\right)$ e de sulfato $\left(983 \mathrm{~cm}^{-1}\right)$ (Figura 56D). 

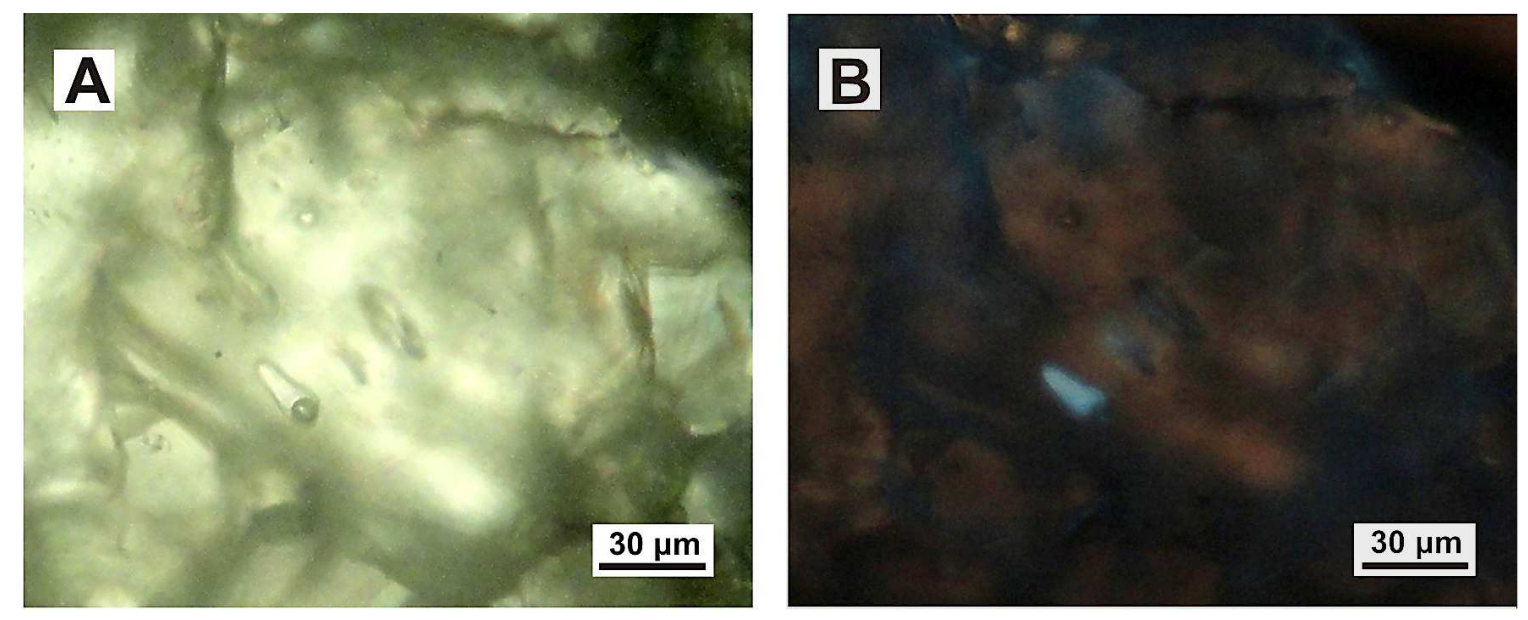

Figura 55. A) Inclusão bifásica sob nicóis paralelos; B) A inclusão apresenta fluorescência azul sob luz ultravioleta.
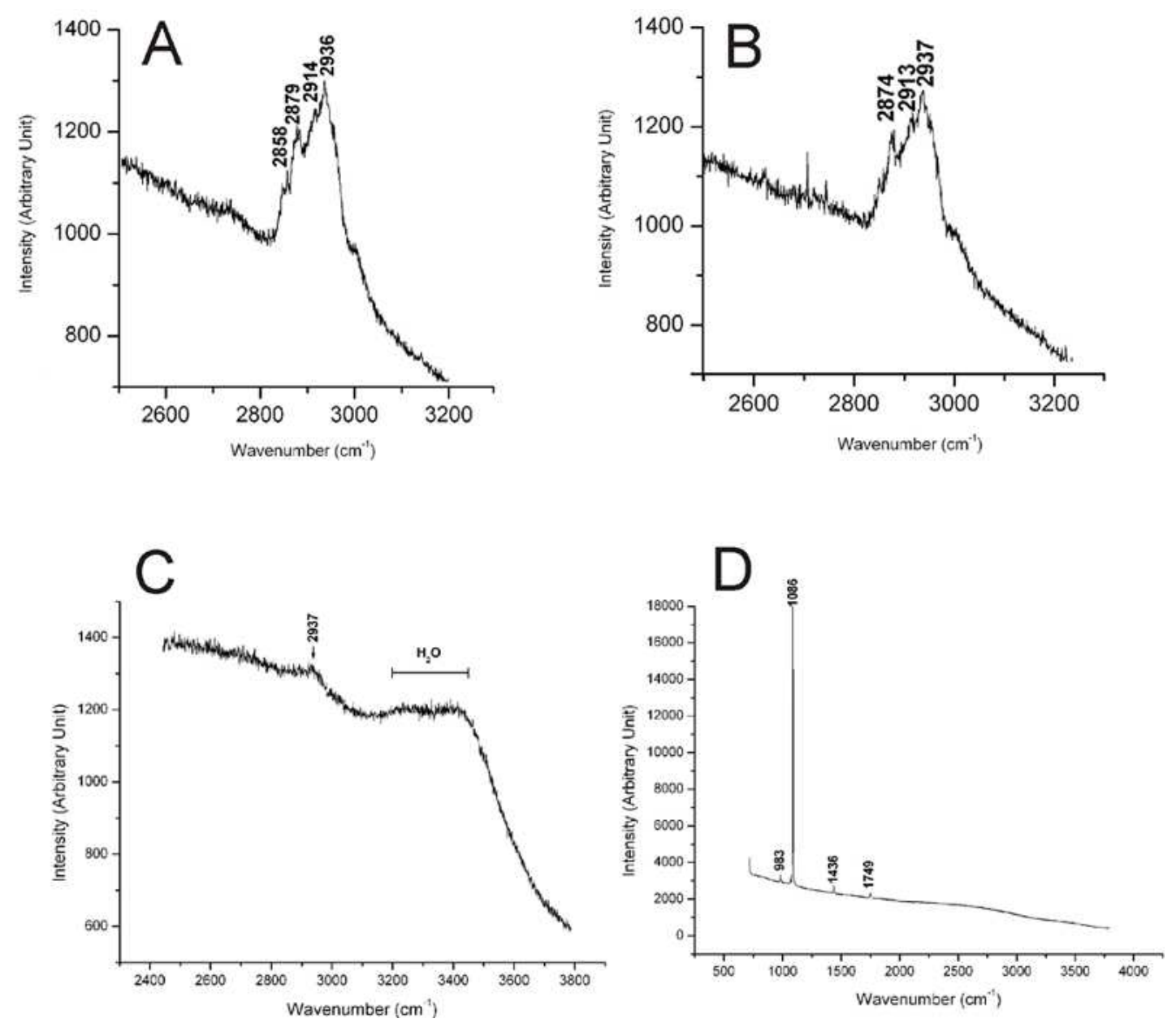

Figura 56. Espectogramas Raman. Inclusão fluida bifásica com picos entre 2700 e $2970 \mathrm{~cm}^{-1}$ nas fases líquida (A) e vapor (B). Inclusão fluida bifásica com picos indicativos da presença de hidrocarbonetos e água (C). Mineral hospedeiro com picos da calcita e de sulfato (D). 


\subsubsection{Inclusões em calcita espática de cavidades de dissolução de}

packstone/grainstone oolítico brechado (Taguaí, SP)

Medidas de microtermometria de inclusões fluidas aquo-salinas foram obtidas em calcita espática de preenchimento de cavidades de dissolução de packstone/grainstone oolítico brechado, Formação Teresina na região de Taguaí, amostra IP-06-R7. As inclusões fluidas são bifásicas, muitas das quais com morfologia de cristal negativo, e estão distribuídas aleatoriamente no cristal (origem primária). Apresentam razões $V_{V A P} / V_{I F}$ (calculado) semelhantes, com média entre 0,20 a 0,30 (Figura 57).

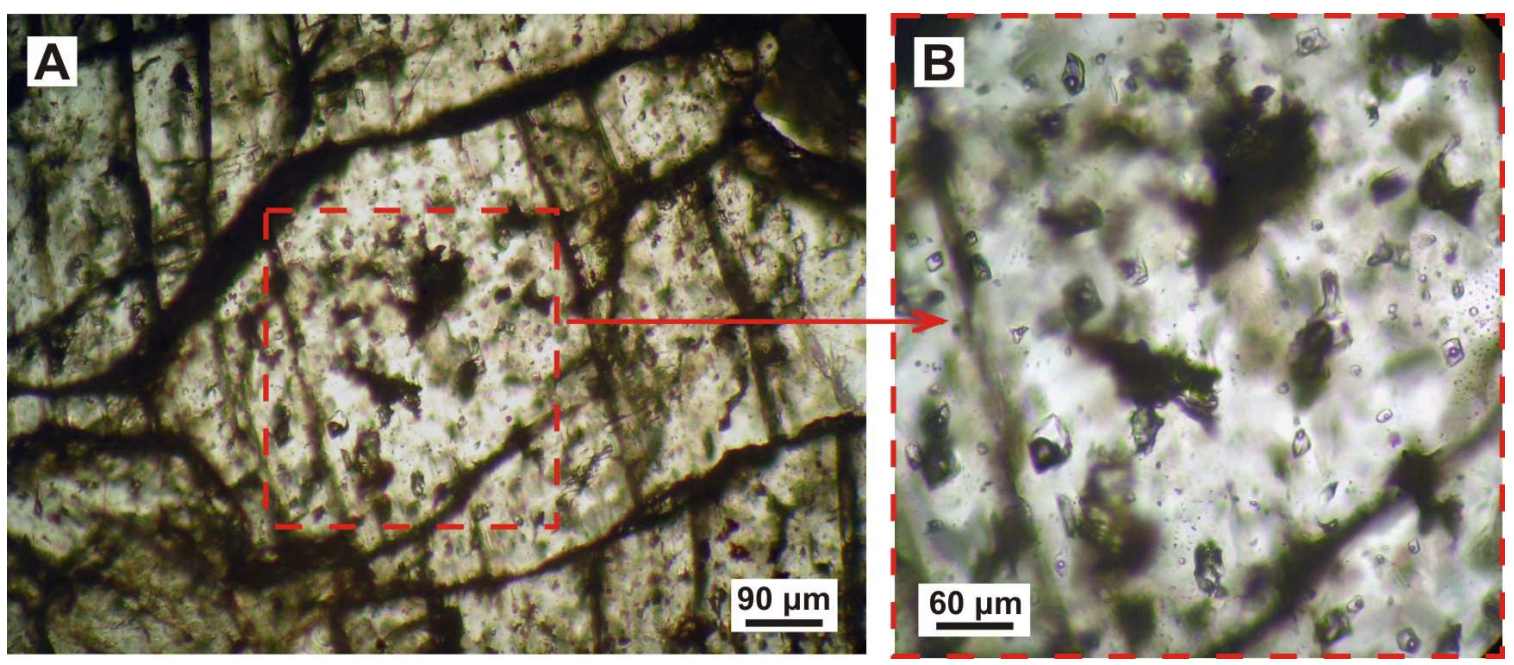

Figura 57. A e B) Associação de inclusões fluidas primárias em calcita espática de cavidades de dissolução da fácies packstone/grainstone oolítico brechado. Compreende inclusões bifásicas, distribuídas aleatoriamente e com morfologia de cristal negativo. Amostra IP-06-R7.

Os valores de TH obtidos para essas inclusões fluidas variaram de 245,7 a $324,9^{\circ} \mathrm{C}$, com moda entre 260 e $280^{\circ} \mathrm{C}$. As temperaturas do ponto eutético (TE) variaram de $-49,6$ a $-26,0^{\circ} \mathrm{C}$ e as temperaturas de fusão do gelo (TFG) de -23,3 a $3,2^{\circ} \mathrm{C}$. Essas TFG caracterizam fluidos com salinidades contrastantes, desde muito salinos a pouco ou moderadamente salinos, ( 5 a $25 \%$ em peso equivalente de $\mathrm{NaCl}$ ) respectivamente. Os histogramas referentes às TH, TE e TFG obtidas em inclusões fluidas de calcita espática de cavidades de dissolução da fácies packstone/grainstone oolítico brechado encontram-se na Figura 58. 


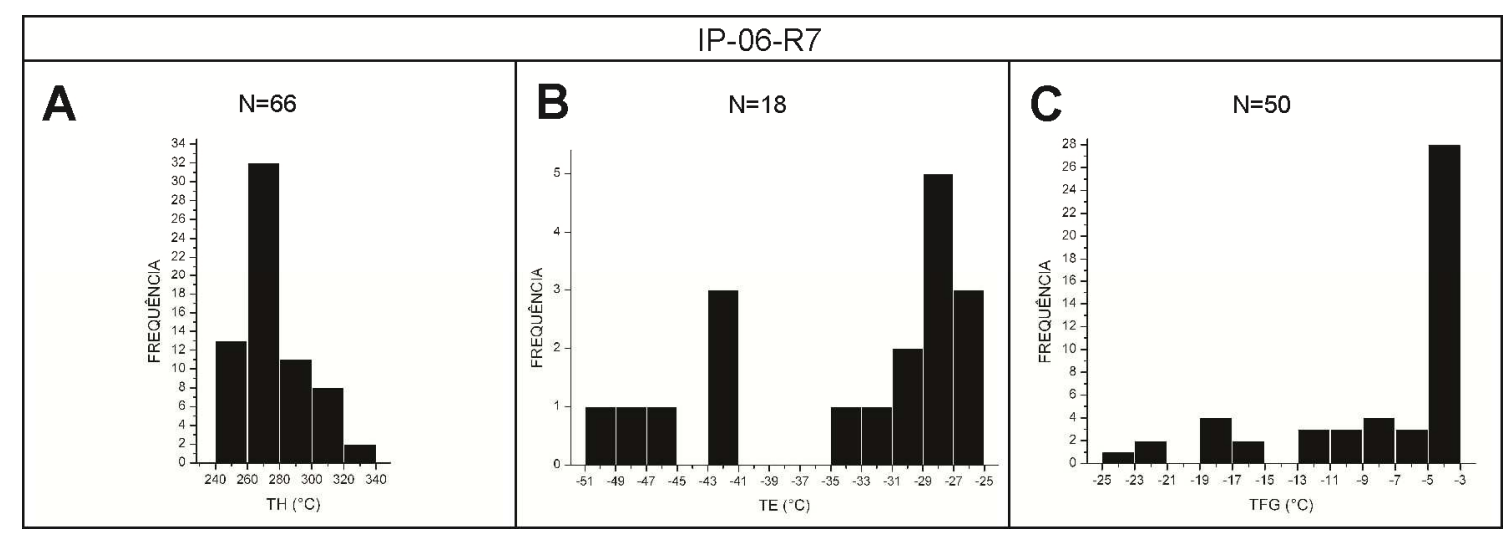

Figura 58. A) Distribuições de freqüência das temperaturas de homogeneização - TH (A), do ponto eutético - TE (B) e de fusão do gelo - TFG (C), medidas em calcita espática de cavidades de dissolução da fácies packstone/grainstone oolítico brechado (amostra IP-06-R7).

\subsubsection{Inclusões em veio de calcita vertical de dique básico do magmatismo Serra Geral (Fartura, SP)}

As associações de inclusões fluidas dos veios verticais de calcita (amostra JZ16A) hospedados em dique básico associado ao evento magmático Serra Geral compreendem inclusões bifásicas, predominantes, e monofásicas (Figura 59). Inclusões orientadas com formas irregulares ou elípticas são mais freqüentes, embora algumas inclusões bifásicas distribuídas aleatoriamente ocorram como cristais negativos de contornos triangulares e quadrados. Inclusões bifásicas com feições de estrangulamento (necking down) são comuns. A maioria das inclusões monofásicas encontra-se associada às bifásicas apresentando feições de necking down. As inclusões parecem terminar no, e portanto, são secundárias. $A$ média do $\mathrm{V}_{\mathrm{VAP}} / \mathrm{V}_{\mathrm{IF}}$ é de 0,08, com mínimo de 0,03 e máximo de 0,30. Os valores de TH obtidos em inclusões sem feições de estrangulamento variaram de 80 a $246^{\circ} \mathrm{C}$, com um valor modal entre 140 e $160^{\circ} \mathrm{C}$. As medidas de resfriamento apresentaram temperaturas do ponto eutético (TE) com valores compreendidos de -50 a $-36^{\circ} \mathrm{C}$ e temperaturas de fusão do gelo (TFG) entre $-1,5$ e $0^{\circ} \mathrm{C}$. Valores para TFG verificados acima de $0^{\circ} \mathrm{C}$ podem ocorrer devido à metaestabilidade. Isto é característico do aprisionamento de fluidos pouco salinos a temperaturas baixas ou moderadas em inclusões que apresentam dimensões e bolhas muito reduzidas, < $10 \mu \mathrm{m}$ (Roedder, 1984). O intervalo dos valores de TFG obtidos caracteriza fluidos de baixa salinidade $(0-3 \%$ em peso equivalente de $\mathrm{NaCl}$ ). Os histogramas das inclusões fluidas do veio vertical de calcita encontram-se na Figura 60. 

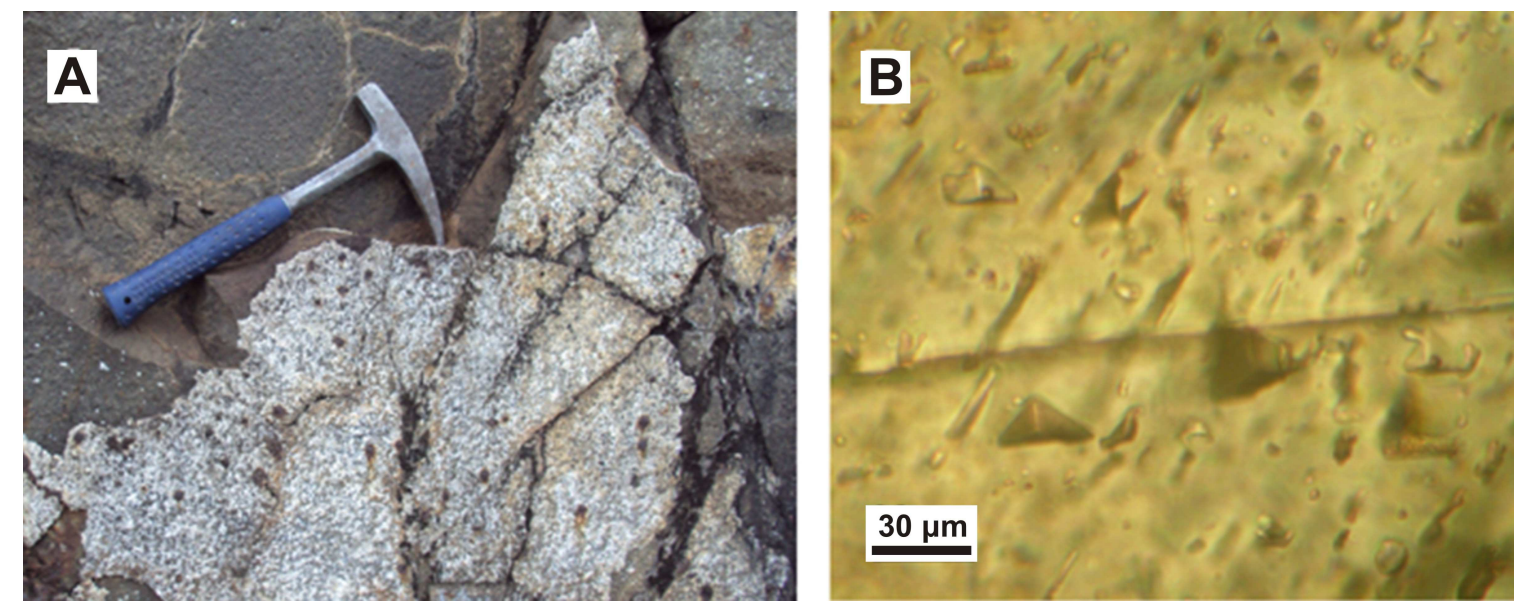

Figura 59. A) Veios verticais de calcita em dique básico associado ao evento magmático Serra Geral (JZ-16A); B) A associação de inclusões fluidas do veio vertical de calcita compreende inclusões monofásicas e bifásicas orientadas, irregulares ou elípticas, além de inclusões bifásicas triangulares. Amostra JZ-16A.

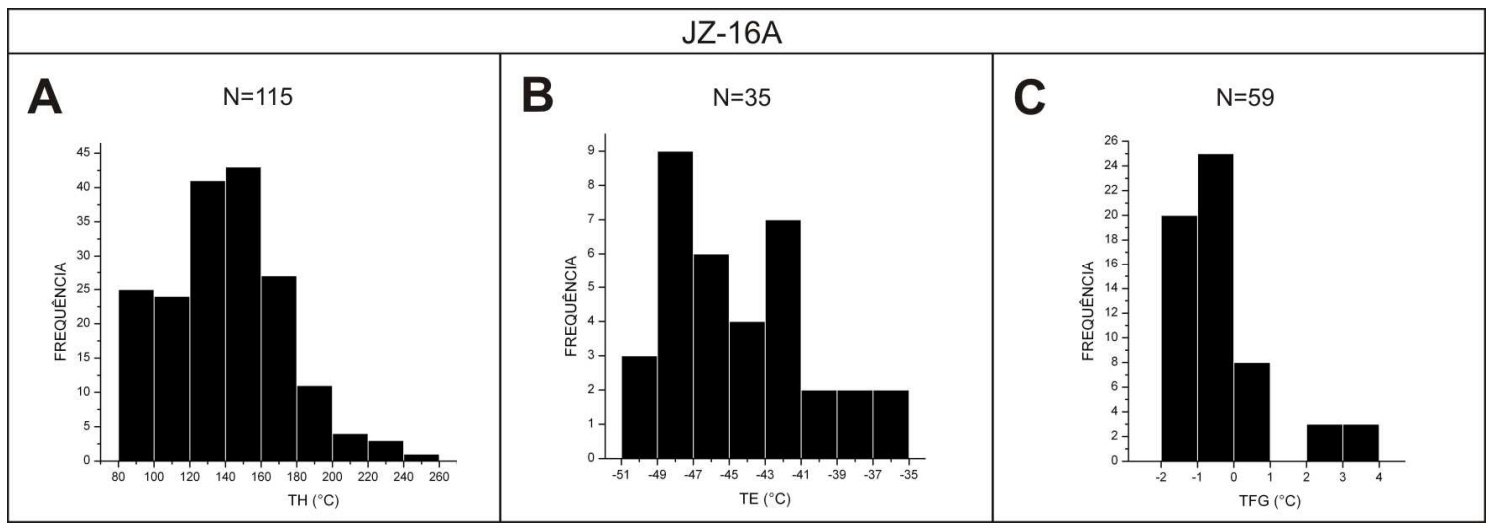

Figura 60. A) Distribuições de freqüência das temperaturas de homogeneização - $T H$ (A), do ponto eutético - TE (B) e de fusão do gelo - TFG (C), medidas em calcita de veio vertical hospedado em dique básico associado ao evento magmático Serra Geral (amostra JZ-16A).

\subsubsection{Inclusões em cristal de quartzo de geodo de cone silicoso} (Anhembi, SP)

Cristais de quartzo (amostra IP-22B) com tamanho médio de $1 \mathrm{~cm}$ (eixo maior) que formam geodos no núcleo dos cones silicosos foram analisados para a microtermometria de inclusões fluidas. As inclusões fluidas do quartzo são bifásicas ou monofásicas, incolores e alongadas. Apresentam-se orientadas e terminam no limite do cristal, o que sugere origem secundária (Figura 61). 


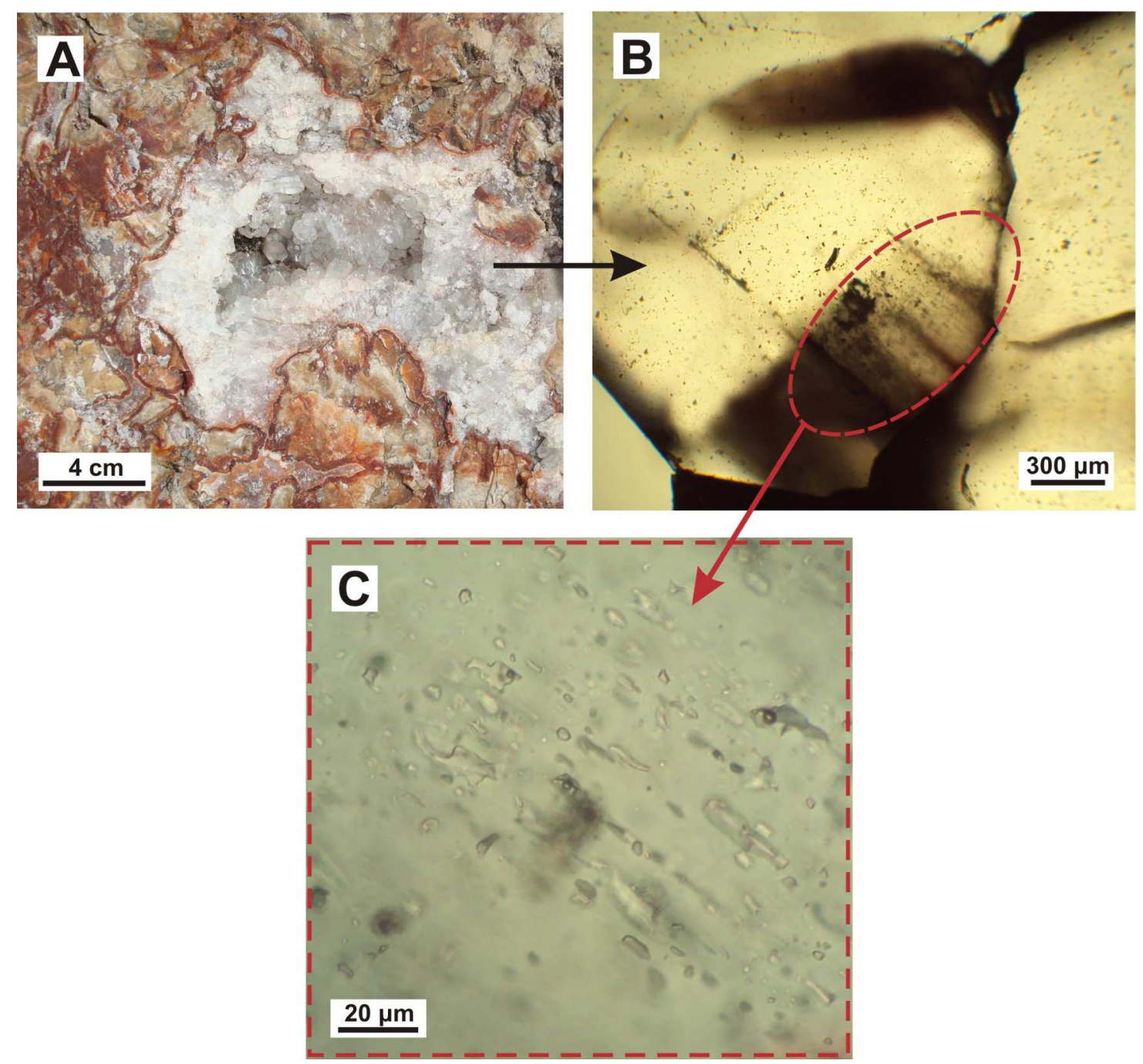

Figura 61. A) Geodo de cristais de quartzo em cone silicoso; B e C) Inclusões fluidas bifásicas e monofásicas em cristal de quartzo. Amostra IP-22B.

As temperaturas de homogeneização dos fluidos (TH) variaram de 55,8 a $177,6^{\circ} \mathrm{C}$, com modas entre $80^{\circ} \mathrm{C}$ e $100^{\circ} \mathrm{C}$, enquanto que as temperaturas do ponto eutético (TE) apresentaram valores entre $-57,8$ e $-43,5^{\circ} \mathrm{C}$. A salinidade indicada pelas temperaturas de fusão do gelo (TFG), com valores de $-5,7$ a $-11,4^{\circ} \mathrm{C}$, variou de $11,3 \mathrm{a}$ $15,7 \%$ em peso equivalente de $\mathrm{NaCl}$, sendo relativamente alta. Os histogramas dos dados microtermométricos das inclusões fluidas em geodo de quartzo encontram-se na Figura 62. 


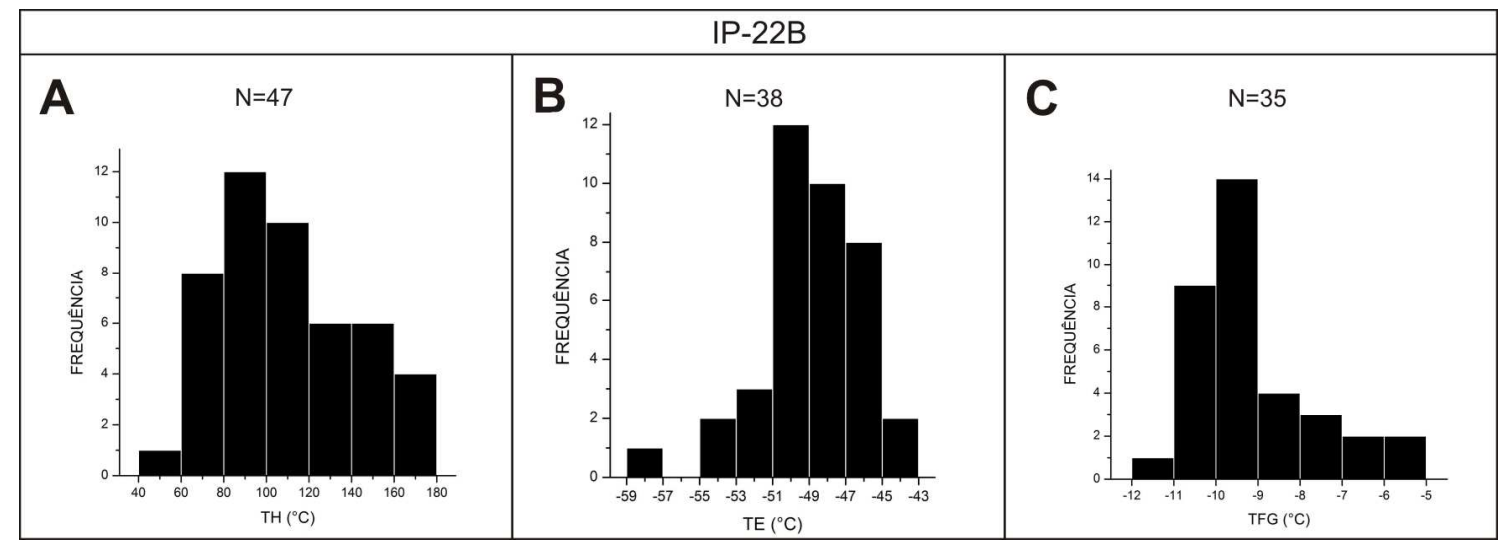

Figura 62. Distribuições de freqüência das temperaturas de homogeneização - TH (A), do ponto eutético - TE (B) e de fusão do gelo - TFG (C), medidas em cristais de quartzo de geodo de cone silicoso (amostra IP-22B).

\subsubsection{Inclusões em calcita de fenda de tração (Jacarezinho, PR)}

Nos arredores do município de Jacarezinho, PR, inclusões fluidas aquo-salinas presentes em cristais de calcita espática, amostra JZ-04A, que ocorrem como preenchimento de fenda de tração subvertical foram analisadas para obtenção de dados microtermométricos. As inclusões fluidas são incolores, bifásicas, com morfologia de cristal negativo e apresentam-se alinhadas no interior do cristal de calcita e, portanto, têm origem pseudo-secundária (Figura 63). Os valores de TH variaram de 98,4 a $177,8^{\circ} \mathrm{C}$, com moda entre 140 e $160^{\circ} \mathrm{C}$. As TE ficaram compreendidas entre os valores $-49,1$ e $-41,2^{\circ} \mathrm{C}$ e as TFG variaram de $-2,7$ a $-0,5^{\circ} \mathrm{C}, 0$ que indica baixa salinidade $(0,9$ a $4,5 \%$ em peso equivalente de $\mathrm{NaCl})$. Os histogramas das inclusões fluidas em calcita da fenda de tração encontram-se na Figura 64. 


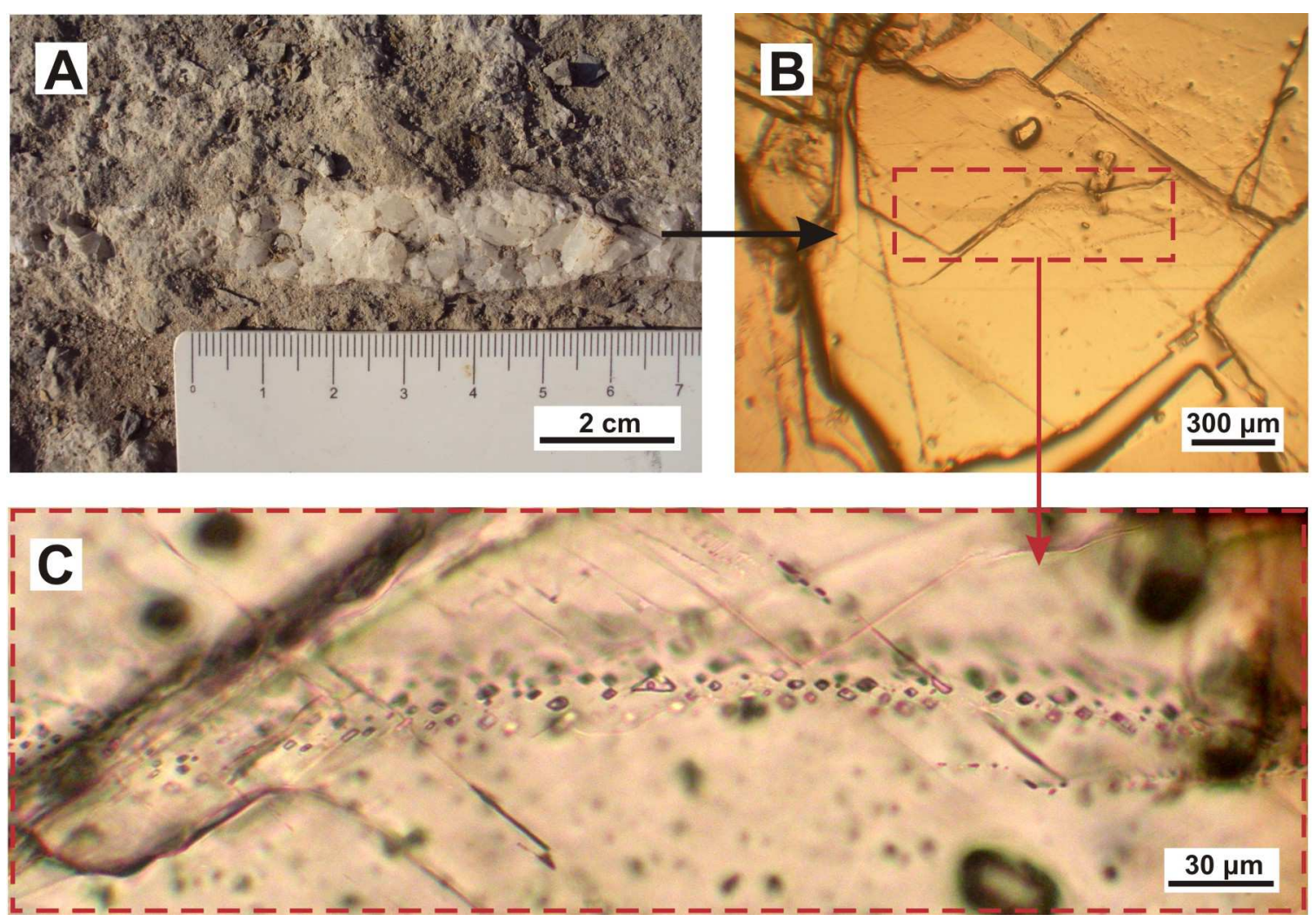

Figura 63. Trilha de inclusões fluidas bifásicas pseudo-secundárias em cristal de calcita da fenda de tração. Amostra JZ-04A.

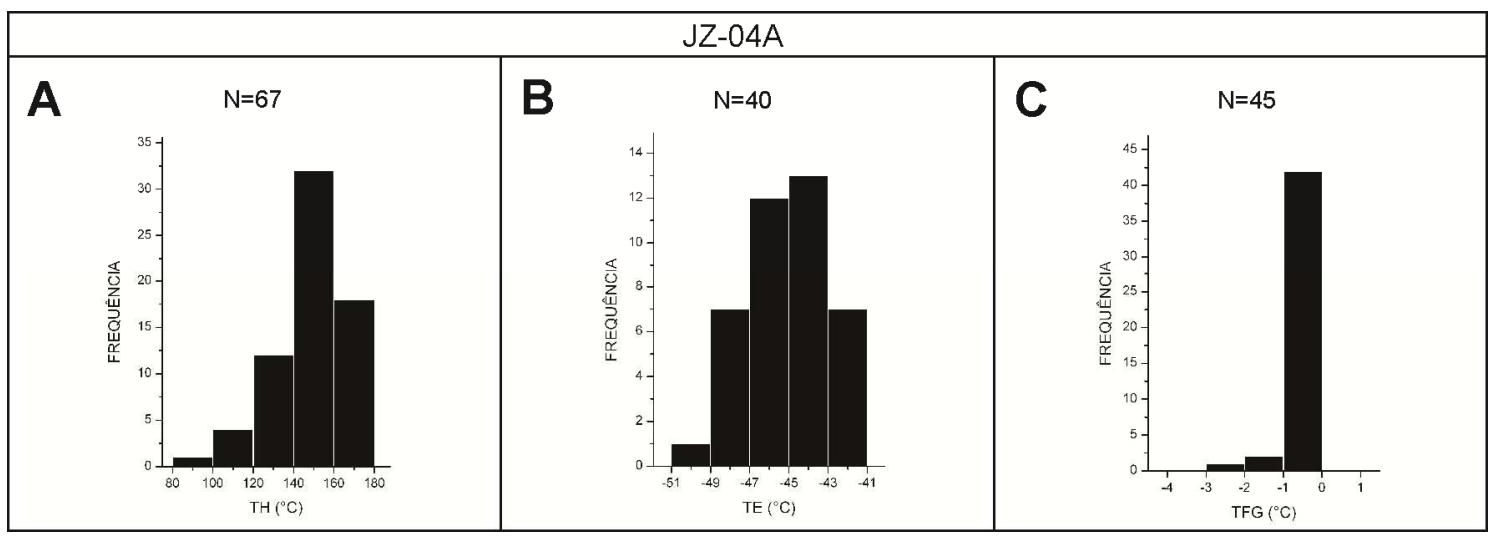

Figura 64. Distribuições de freqüência das temperaturas de homogeneização - TH (A), do ponto eutético - TE (B) e de fusão do gelo - TFG (C), medidas em calcita de fenda de tração (amostra JZ-04A).

\subsubsection{Inclusões em calcita blocosa (blocky) de cavidades de dissolução} de chert nodular brechado (Jacarezinho, PR)

Análises de inclusões fluidas foram realizadas em três amostras (JZ-05, JZ05A, JZ-02C) de cimento de calcita blocosa em Jacarezinho, PR. Essas amostras são representativas de diferentes níveis do afloramento JZ-05 (amostras JZ-05A e JZ-05) e 
do afloramento JZ-02 (amostra JZ-02C). Esses níveis correspondem à fácies chert nodular brechado.

As inclusões fluidas são bifásicas, incolores e têm morfologia de cristal negativo. Quanto à distribuição dentro do cristal, as inclusões apresentam-se, geralmente, orientadas segundo direção preferencial, ao longo de provável plano de fratura. Por vezes, é possível encontrar num mesmo cristal, diversas associaçõess de inclusões fluidas orientadas cada uma numa direção. A origem dessas inclusões orientadas é secundária, já que se encontram dispostas pelo menos até o limite do cristal de calcita (Figura 65).
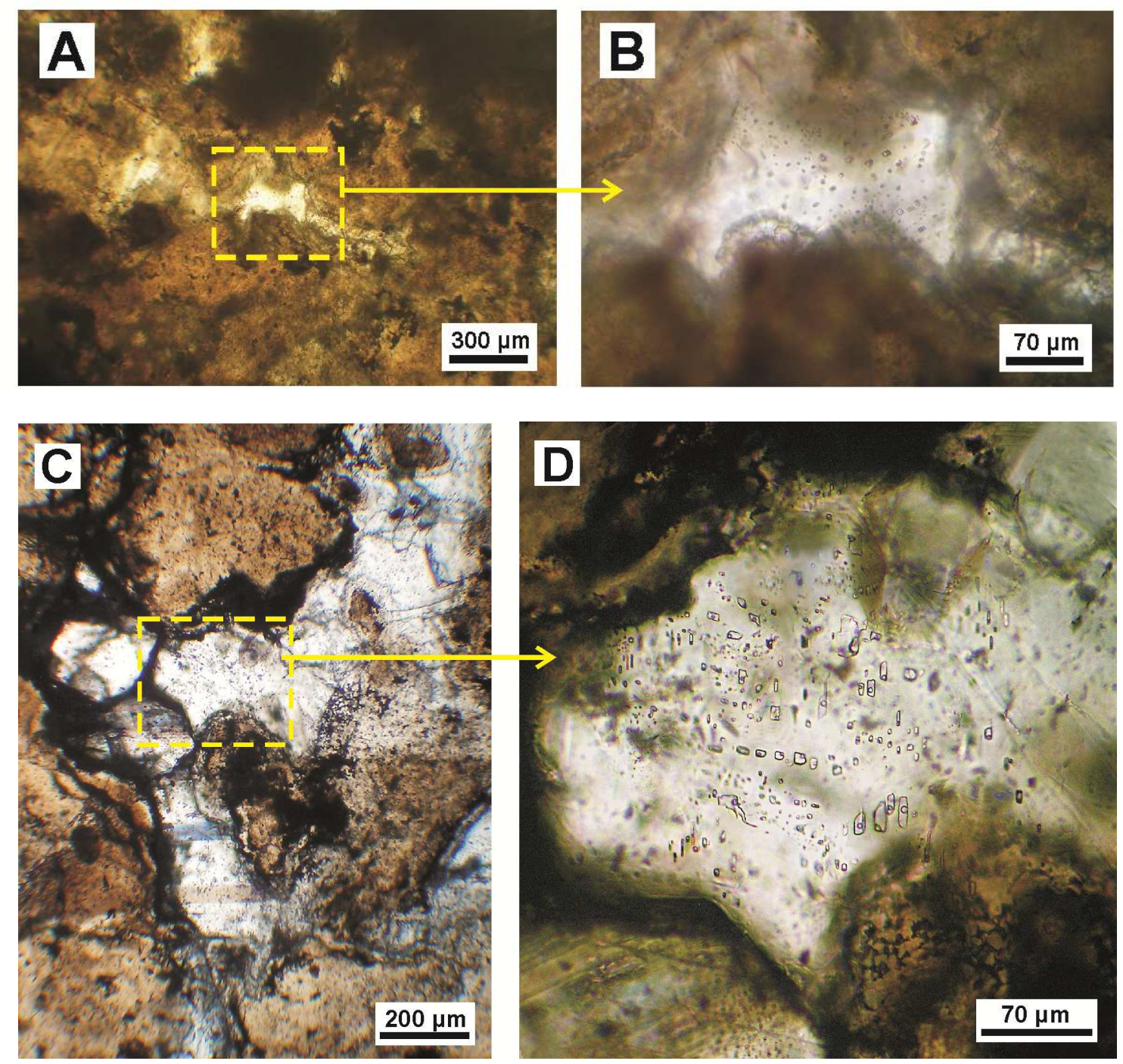


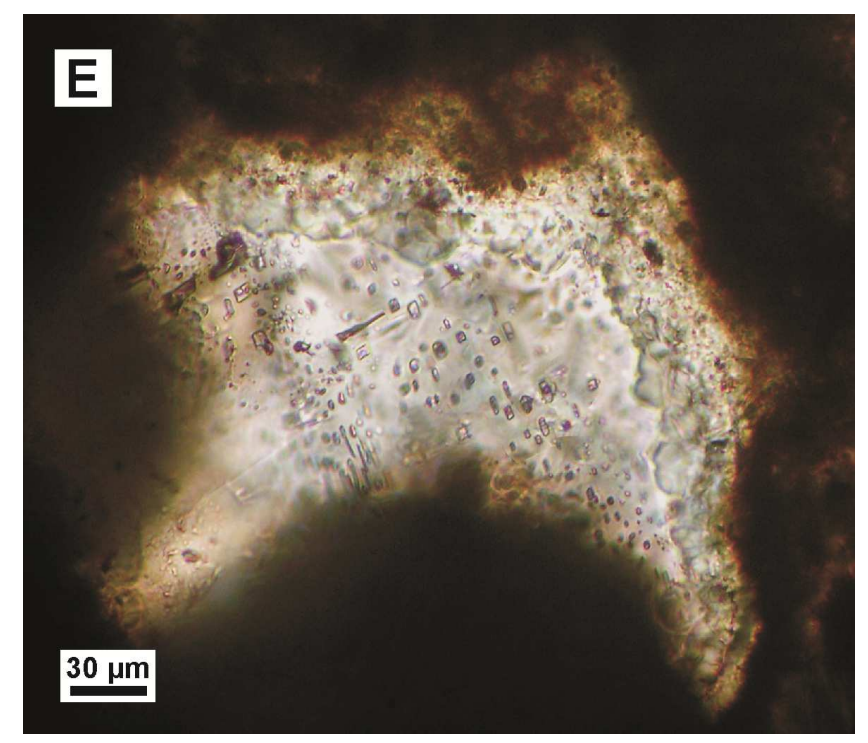

Figura 65. A, B, C, D e E) Inclusões fluidas bifásicas, incolores e com morfologia de cristal negativo, em calcita espática no interior de cavidade da fácies chert nodular brechado. Algumas inclusões aparentam distribuição mais aleatória, mas a maioria segue orientação preferencial e alcançam o limite do cristal de calcita. Amostras JZ02C, JZ-05 e JZ-05A, respectivamente.

$\mathrm{Na}$ amostra JZ-02C, a razão $\mathrm{V}_{\mathrm{VAP}} / \mathrm{V}_{\mathrm{IF}}$ variou de 0,15 a 0,30 . Os valores de $\mathrm{TH}$ variaram de 199,0 a $384,8^{\circ} \mathrm{C}$, com moda entre 240 e $260^{\circ} \mathrm{C}$ e as TE de $-52,6$ a $40,1^{\circ} \mathrm{C}$. As TFG variaram de $-2,4$ a $-0,5^{\circ} \mathrm{C}$, o que indica baixa salinidade, com $1,1 \mathrm{a}$ $4,1 \%$ em peso equivalente de $\mathrm{NaCl}$. Os histogramas das temperaturas de homogeneização (TH) e resfriamento (TE e TFG) das inclusões fluidas em calcita blocosa de cavidade de dissolução da fácies chert nodular brechado, amostra JZ-05, encontram-se na Figura 66.

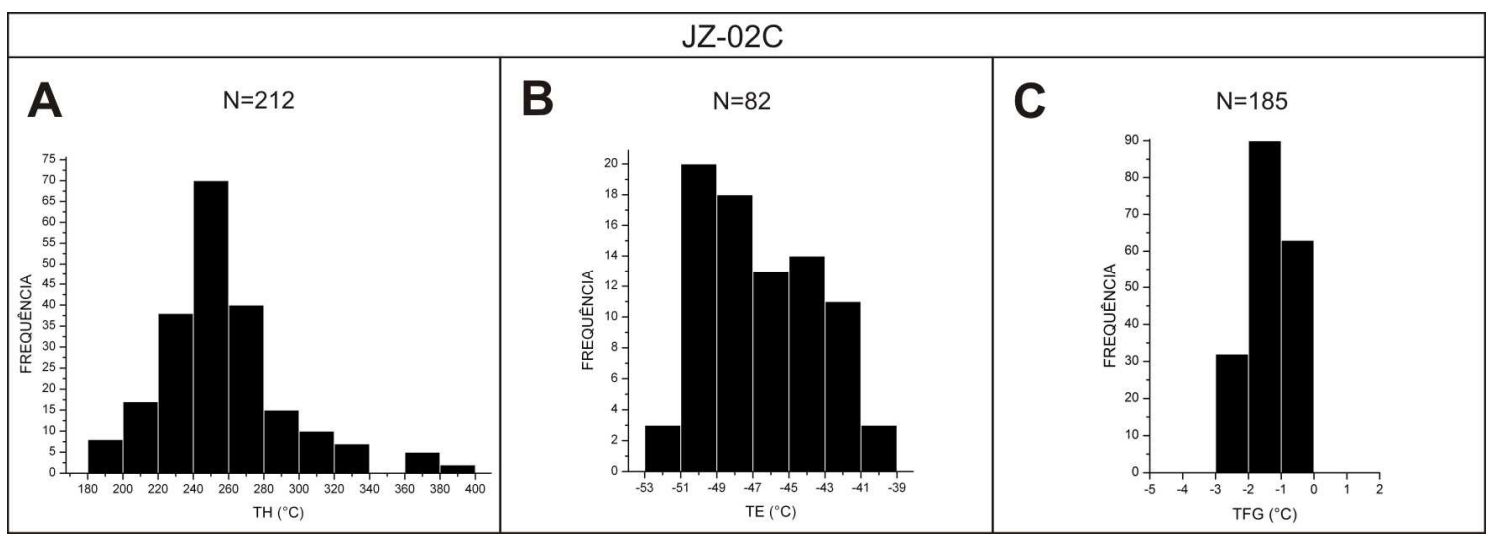

Figura 66. Distribuições de freqüência das temperaturas de homogeneização - TH (A), do ponto eutético - TE (B) e de fusão do gelo - TFG (C), medidas em cimento de calcita blocosa em cavidades de dissolução de chert nodular brechado (amostra JZ02C). 
$\mathrm{Na}$ amostra JZ-05, diversas associações de inclusões fluidas ocorrem alinhadas em diferentes direções de cicatrização de fratura. Os valores da razão $\mathrm{V}_{\mathrm{VAP}} / \mathrm{V}_{\mathrm{IF}}$ variaram, em média, de 0,10 a 0,15 . Para as diversas associações de inclusões fluidas orientadas em diferentes direções, o intervalo da variação dos valores de $\mathrm{TH}$ obtidos não apresentou diferença significativa segundo associações presentes em certa direção de cicatrização de fratura. O mesmo ocorreu para os valores obtidos de TE e TFG. Desta forma, os dados termométricos obtidos de todas as associações serão apresentados em conjunto, de acordo com o tipo de temperatura obtido (TH, TE e TFG).

Os valores de $\mathrm{TH}$ variaram de 136,8 a $286,5^{\circ} \mathrm{C}$, com moda entre 180 e $200^{\circ} \mathrm{C}$ e as de TE apresentaram medidas entre $-53,1$ e $-40,5^{\circ} \mathrm{C}$. Valores de TFG entre $-4,5$ e $0,8^{\circ} \mathrm{C}$ indicam salinidade baixa a moderada, com 1,4 a $7,3 \%$ em peso equivalente de $\mathrm{NaCl}$. Os histogramas dos dados microtermométricos (TH, TE e TFG) das inclusões fluidas em calcita blocosa da amostra JZ-05 encontram-se na Figura 67.

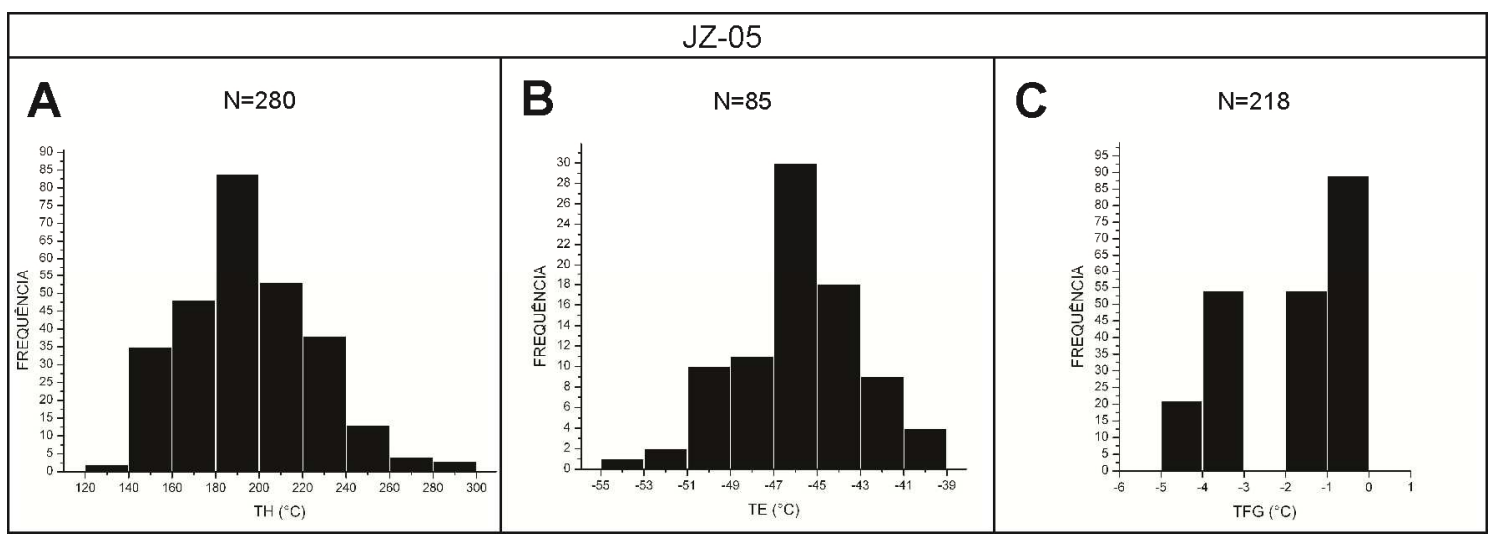

Figura 67. Distribuições de freqüência das temperaturas de homogeneização - TH (A), do ponto eutético - TE (B) e de fusão do gelo - TFG (C) das inclusões fluidas em calcita blocosa de cavidade da fácies chert nodular brechado (amostra JZ-05).

$\mathrm{Na}$ amostra JZ-05A, a razão $\mathrm{V}_{\mathrm{VAP}} / \mathrm{V}_{\mathrm{IF}}$ variou 0,10 e 0,30 . Os valores de $\mathrm{TH}$ situaram-se entre 115,2 e $380,2^{\circ} \mathrm{C}$, com moda entre 220 e $240^{\circ} \mathrm{C}$, e as medidas de TE entre $-55,7$ a $-41,0^{\circ} \mathrm{C}$. Dados de TFG de $-2,2$ a $0^{\circ} \mathrm{C}$ indicam baixa salinidade, com 0 a $3,7 \%$ em peso equivalente de $\mathrm{NaCl}$. Os histogramas das temperaturas de aquecimento (TH) e resfriamento (TE e TFG) das inclusões fluidas em calcita blocosa da amostra JZ-05A encontram-se na Figura 68. 


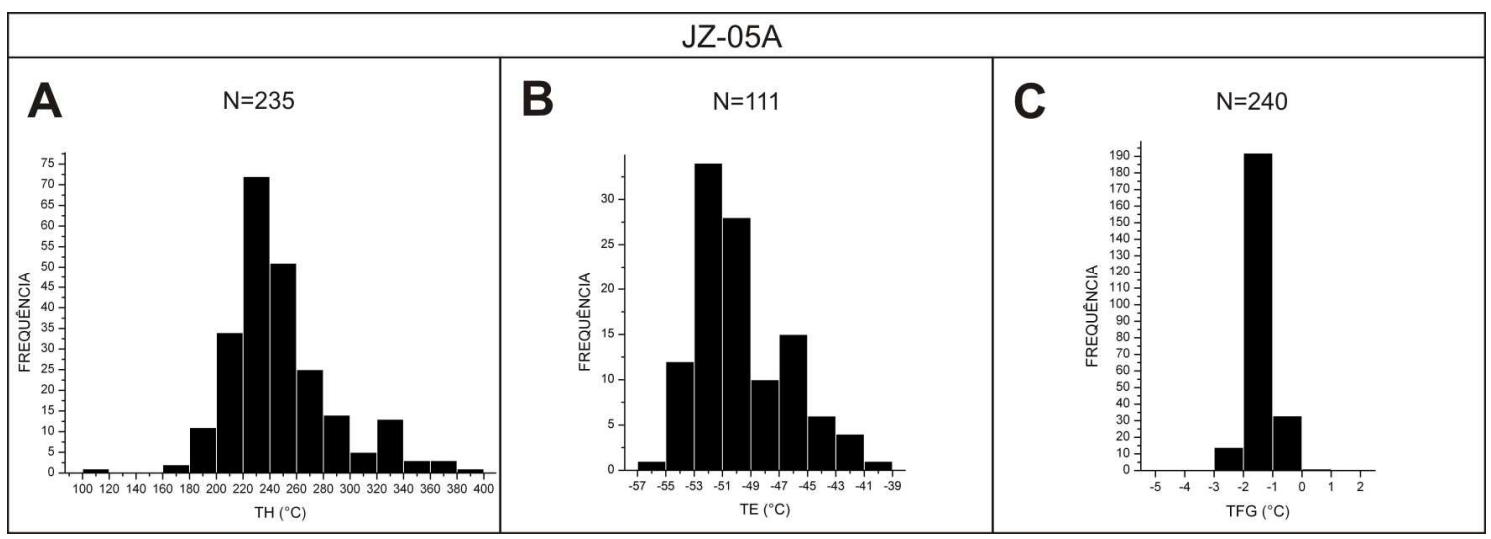

Figura 68. Distribuições de freqüências das temperaturas de homogeneização - TH (A), do ponto eutético - TE (B) e de fusão do gelo - TFG (C) das inclusões fluidas em calcita blocosa de cavidade de dissolução de chert nodular brechado (amostra JZ05A).

\subsubsection{Inclusões em romboedros de calcita espática (Jacarezinho, PR)}

Inclusões fluidas aquo-salinas que ocorrem no interior de cristais romboédricos de calcita (amostra JZ-05D) foram utilizadas para análise microtermométrica. Esses cristais romboédricos ocorrem imersos na matriz da fácies mudstone parcialmente silicificado e foram substituídos por calcita espática (Figura 69).
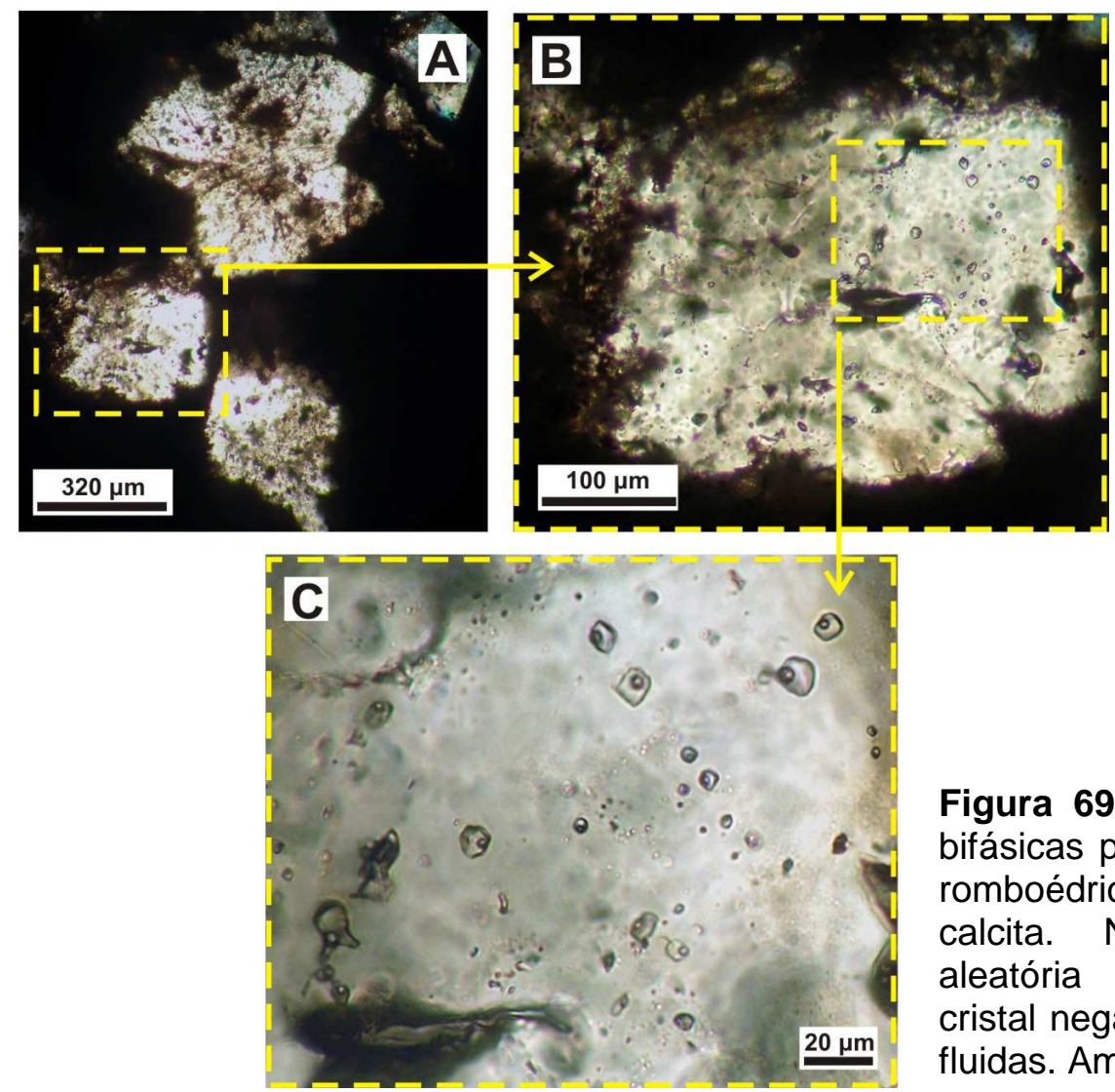

Figura 69. Inclusões fluidas bifásicas primárias em cristal romboédrico substituído por calcita. Notar distribuição aleatória e morfologia em cristal negativo das inclusões fluidas. Amostra JZ-05D. 
As inclusões fluidas presentes nos cristais romboédricos de calcita são incolores e bifásicas, sendo que a maioria tem morfologia em cristal negativo. Estas inclusões são de origem aparentemente primária, pois parecem estar distribuídas aleatoriamente no interior dos cristais romboédricos. Apresentam razões $V_{V A P} / V_{I F}$ semelhantes, com média em torno de 0,15, com algumas apresentando maior porcentagem volumétrica de vapor. Os valores de $\mathrm{TH}$ variaram de 194,5 a $312,0^{\circ} \mathrm{C}$, com moda entre 260 e $280^{\circ} \mathrm{C}$ e as de TE variaram de $-52,7$ a $-40,5^{\circ} \mathrm{C}$. As TFG de 16,6 a $-3,7^{\circ} \mathrm{C}$ indicam elevada variação da salinidade entre 20,4 e 6,1\% em peso equivalente de $\mathrm{NaCl}$, o que indica salinidade moderada a muito elevada. A moda do intervalo dos valores de TFG entre -4 e $-5^{\circ} \mathrm{C}$ aponta para predomínio de fluido com salinidade mais moderada (6,5 a 7,5\% em peso equivalente de $\mathrm{NaCl})$. Os histogramas das temperaturas de aquecimento (TH) e resfriamento (TE e TFG) das inclusões fluidas do cimento de calcita espática da amostra JZ-05D encontram-se na Figura 70.

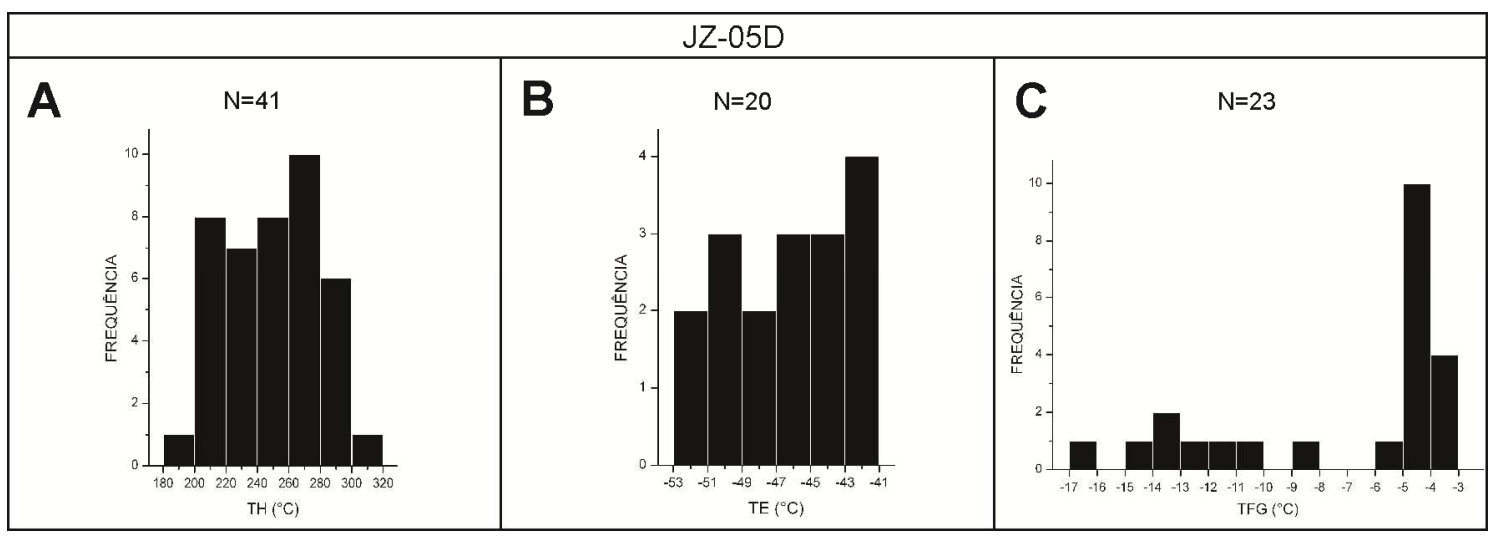

Figura 70. Distribuições de freqüência das temperaturas de homogeneização - TH (A), do ponto eutético - TE (B) e de fusão do gelo - TFG (C) das inclusões fluidas em calcita de substituição de romboedro (amostra JZ-05D).

\subsubsection{Inclusões em calcita de fratura vertical (entre Santo Antonio da} Platina e Joaquim Távora, PR)

As inclusões fluidas ocorrem no interior de cristais de calcita espática da fratura vertical de direção NW em fácies de siltito heterolítico da Formação Teresina, entre Santo Antonio da Platina e Joaquim Távora (amostra JZ-10). As inclusões fluidas têm orientação preferencial, aparentemente definida por cicatrização de fratura conchoidal, portanto são secundárias. As inclusões fluidas são bifásicas, incolores e apresentam morfologia irregular (Figura 71). 

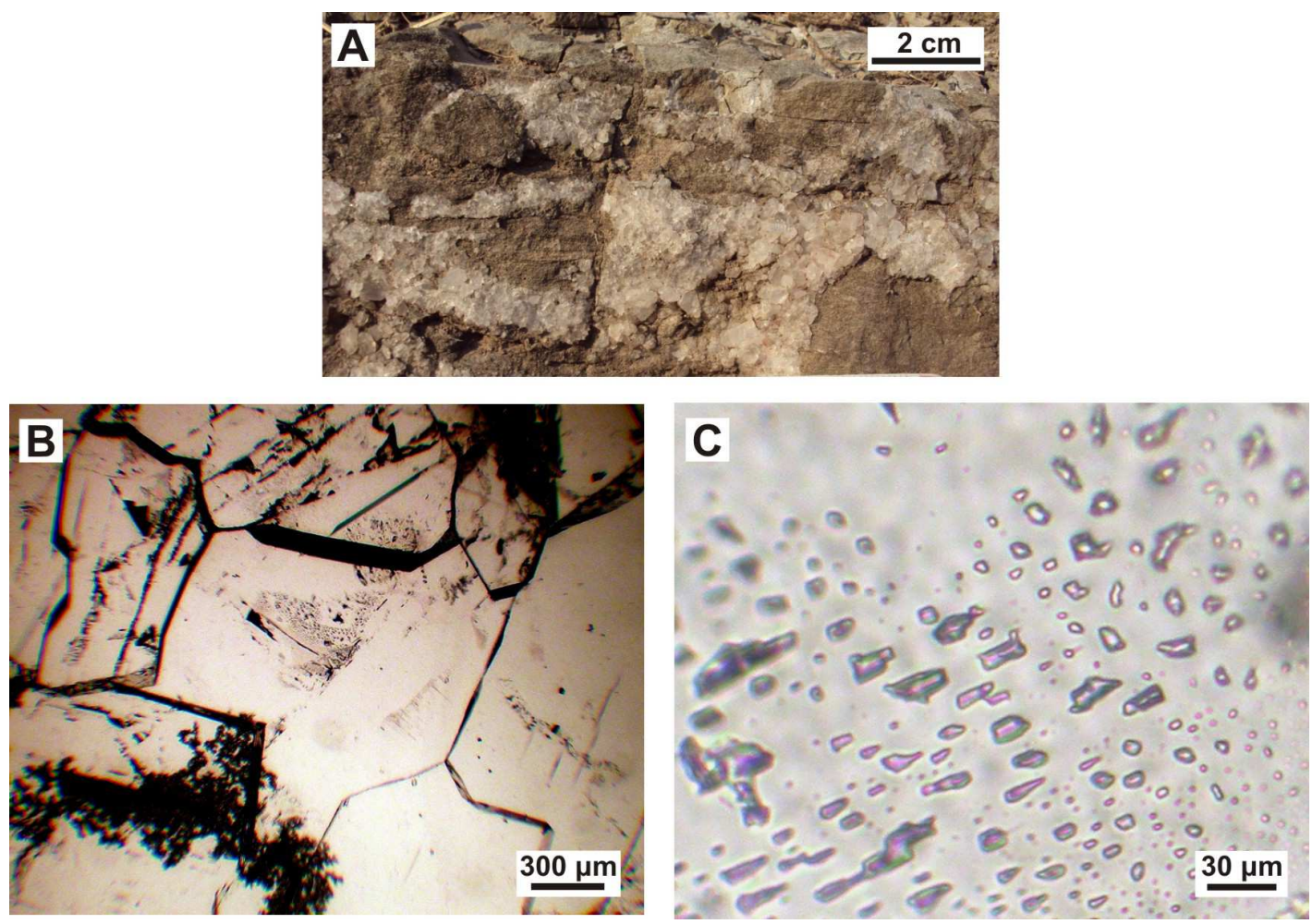

Figura 71. A) Calcita espática em fratura vertical de direção NW na fácies de siltito heterolítico da Formação Teresina; B e C) Inclusões fluidas em provável fratura conchoidal em calcita espática que preenche fratura. Amostra JZ-10.

A proporção $V_{V A P} / V_{\mathrm{IF}}$ variou em média de 0,05 a 0,10 . Os valores de $T H$ variaram de 60,3 a $93,4^{\circ} \mathrm{C}$, com moda entre 80 e $90^{\circ} \mathrm{C}$ (Figura 72). Não foi possível adquirir medidas de TE devido ao desaparecimento da bolha de vapor com o resfriamento o que torna essa medida menos precisa (Goldstein \& Reynolds, 1994). Além disso, as TFG também não foram obtidas, pois as bolhas de vapor não apareceram até temperaturas superiores à $0^{\circ} \mathrm{C}$, o que indica metaestabilidade, e resulta em falsos valores dessas medidas.

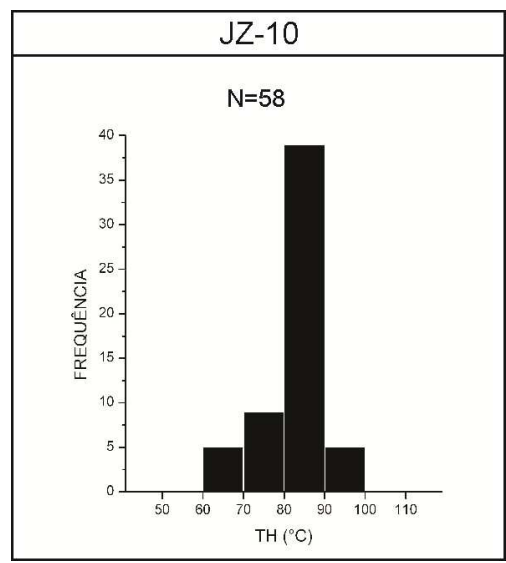

Figura 72. Distribuições de freqüência das temperaturas de homogeneização $(T H)$ das inclusões fluidas em calcita de fratura vertical (amostra JZ-10). 


\subsubsection{Inclusões em veio de quartzo da Formação Corumbataí (Ipeúna, SP)}

Veio vertical de quartzo (amostra MS-1) de direção NW a NNW, que corta a fácies do siltito roxo acinzetando da Formação Corumbataí, apresenta inclusões fluidas aquo-salinas e de hidrocarbonetos. Essas inclusões fluidas estão no interior de megacristais de quartzo e ocorrem alinhadas em trilhas que cortam os limites dos cristais, o que indica origem secundária.

As associações de inclusões fluidas aquo-salinas ocorrem ao longo de uma faixa com diversas trilhas paralelas ou sub-paralelas entre si, que corta vários cristais de quartzo. As associações de inclusões são caracterizadas por co-existência de inclusões bifásicas e monofásicas nos mesmos campos, sendo comum aquelas com morfologia elíptica e de cristal negativo.

As inclusões de hidrocarbonetos ocorrem concentradas numa fratura paralela à faixa formada por diversas trilhas de inclusões fluidas aquo-salinas. As inclusões de hidrocarbonetos estão associadas a presença de outras inclusões sólidas opacas (óxidos ou matéria orgânica).

O veio de quartzo pode ser caracterizado em três porções diferentes de acordo com a textura dos cristais de quartzo e características das suas inclusões fluidas. A primeira porção é caracterizada pela ocorrência de cristais de quartzo eqüidimensionais, dispostos em mosaico e em contato com a rocha hospedeira. Esses cristais não apresentam inclusões (quartzo "limpo"). A segunda porção corresponde à faixa com diversas trilhas de inclusões fluidas aquo-salinas secundárias paralelas à fratura com inclusões de hidrocarbonetos. A terceira porção envolve a zona central do veio de quartzo e ocorre em contato com a fratura de inclusões de hidrocarbonetos. Esta porção abrange cristais euédricos maiores de quartzo desprovidos de inclusões (Figura 73). 


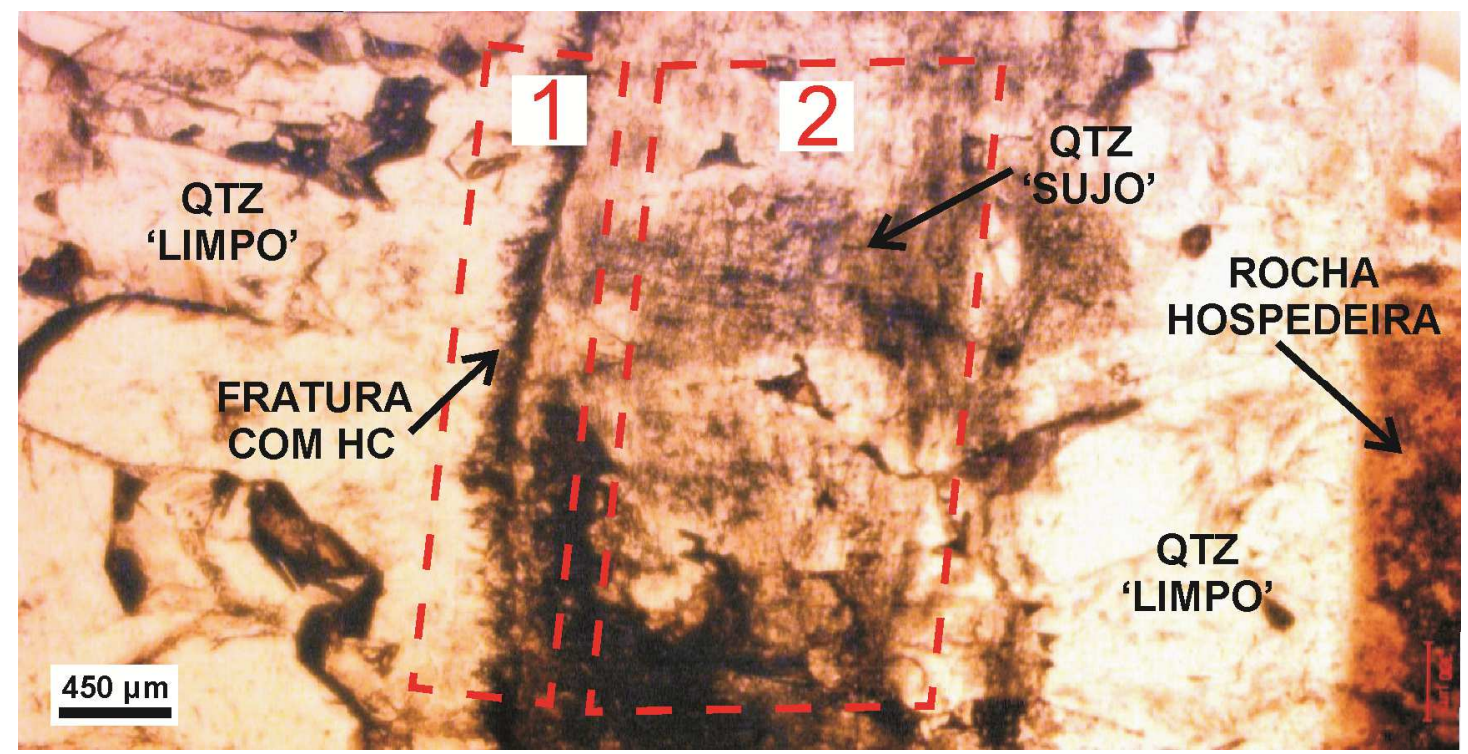

Figura 73. Veio de quartzo (amostras MS-1) dividido em três porções da borda (à direita) ao centro (à esquerda): 1) a primeira porção (borda) envolve cristais eqüidimensionais de quartzo desprovidos de inclusões (QTZ 'LIMPO') dispostos em mosaico em contato com siltito roxo-acinzentado ;2) a segunda porção é caracterizada por trilhas de inclusões fluidas aquo-salinas paralelas à fratura com inclusões de hidrocarbonetos. A concentração de inclusões fluidas nesta faixa confere aspecto 'sujo' aos cristais de quartzo; 3) a terceira porção corresponde a parte central do veio onde ocorrem cristais euédricos de quartzo sem inclusões ('QTZ 'LIMPO'). Imagem sob polarizadores paralelos.

As inclusões de hidrocarbonetos são monofásicas ou bifásicas, com formas alongadas, elípticas ou irregulares (figuras 74 e 75). As inclusões monofásicas aparentemente resultam do estrangulamento de inclusões fluidas bifásicas anteriores. Além disso, inclusões fluidas com feições de escape também são comuns. Para as medidas de microtermometria, foram selecionadas inclusões com morfologia regular sem feições de escape e estrangulamento. As $\mathrm{TH}$ variaram de 79,0 a $215,1^{\circ} \mathrm{C}$, com moda entre 140 e $180^{\circ} \mathrm{C}$.

A microscopia sob luz ultravioleta indica que as inclusões bifásicas de hidrocarbonetos apresentam fluorescência azul-esbranquiçada a amarelada (figuras 74D e 75B). Algumas inclusões de hidrocarboneto de cor amarelada não fluoresceram (Figura 75B). 


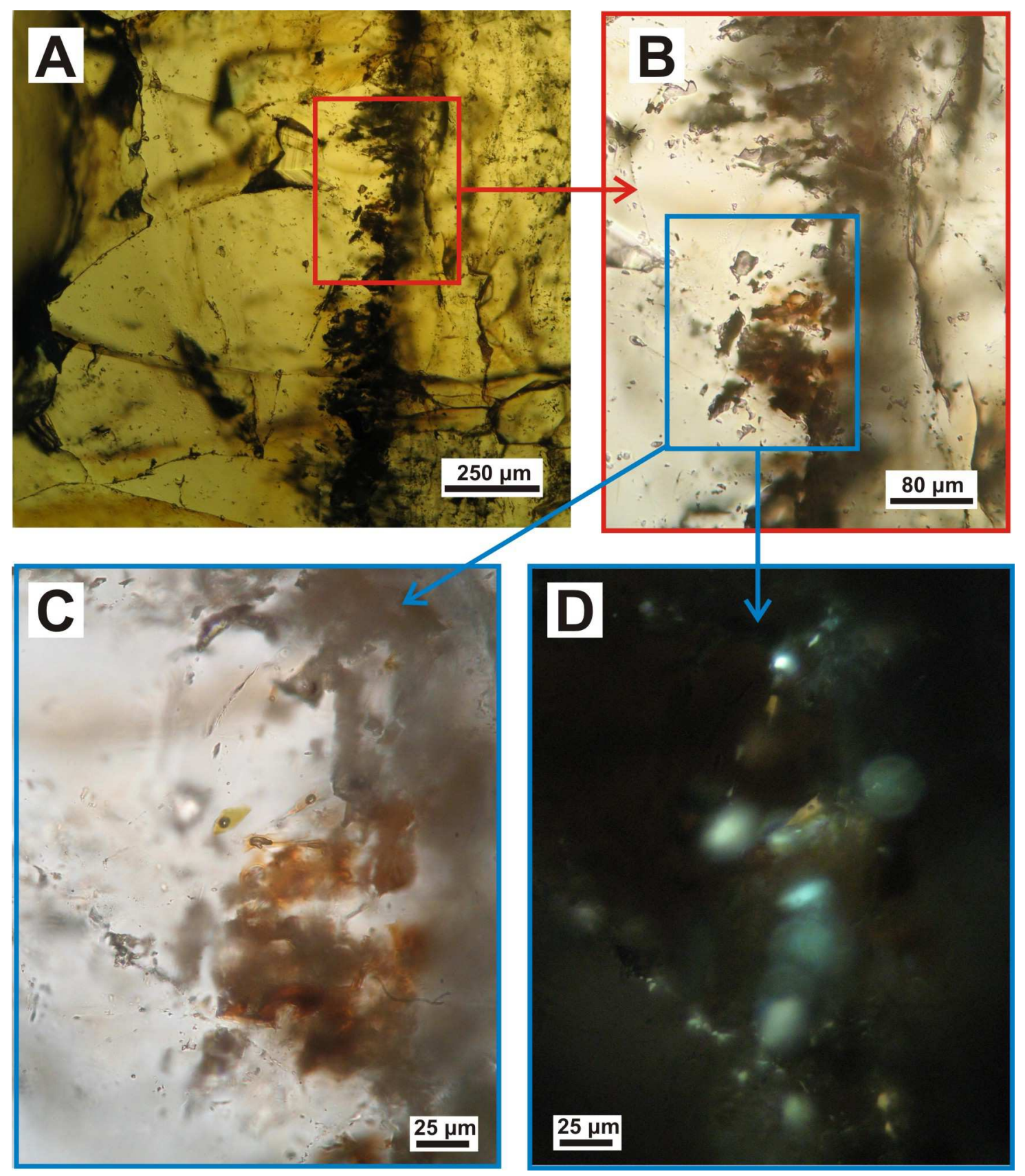

Figura 74. A) Fratura com inclusões fluidas de hidrocarbonetos e inclusões sólidas opacas(óxido ou matéria orgânica?). Imagem sob polarizadores paralelos; B e C) Detalhe da fratura com inclusões de hidrocarbonetos. Imagem sob polarizadores paralelos; D) Inclusões de hidrocarbonetos sob luz UV. Observar a presença de inclusões com fluorescência azul-esbranquiçada e amarelada. Amostra MS-1. 


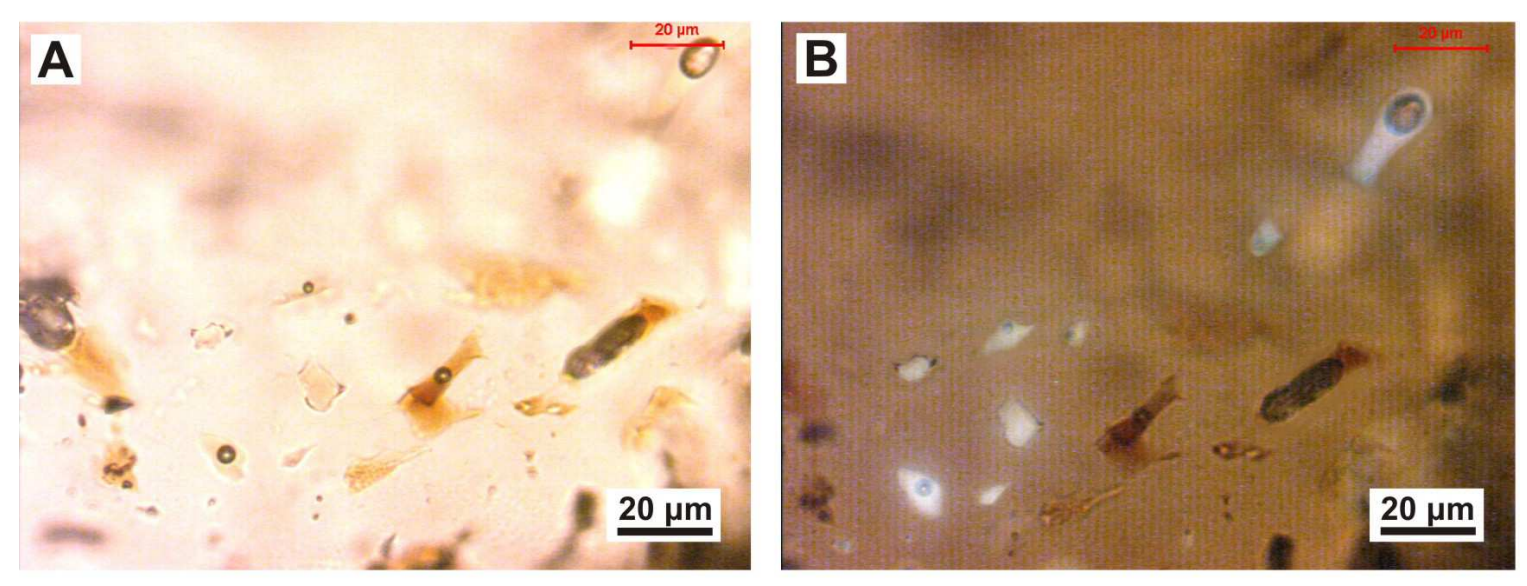

Figura 75. A) Associação de inclusões de hidrocarbonetos sob polarizadores paralelos. Observar feição de escape e estrangulamento em algumas inclusões, o que pode explicar a ocorrência de inclusões monofásicas; B) Fluorescência azulesbranquiçada das inclusões de hidrocarbonetos sob luz UV. Notar que as inclusões em tons de amarelo não fluorescem. Amostra MS-1.

As inclusões aquo-salinas apresentam razões entre o volume da fase vapor e o volume da inclusão relativamente semelhantes, com valor médio entre 0,15 e 0,20 (Figura 76), embora em certas regiões da amostra, as relações volumétricas sejam mais variáveis. Duas gerações de fluidos aquosos foram diferenciadas através das salinidades indicadas pelas medidas de TFG. A primeira, referente às inclusões secundárias dispostas em trilhas (MS-1-Cp1), apresenta salinidade alta com valores entre 19,3 e $20,4 \%$ em peso equivalente de $\mathrm{NaCl}$ (TFG entre $-15,3$ e $-16,6^{\circ} \mathrm{C}$ ). Essas inclusões apresentam TE entre $-52,0$ e $-45,0^{\circ} \mathrm{C}$ e TH entre 111,7 e $170,7^{\circ} \mathrm{C}$, com moda ao redor entre 110 e $130^{\circ} \mathrm{C}$. A segunda geração, representada pelas inclusões secundárias dispostas em trilhas distintas (MS-1-Cp4), apresenta salinidade moderada, com valores entre 4,7 e $8,4 \%$ em peso equivalente de $\mathrm{NaCl}$ (TFG entre $-2,8$ e $-5,3^{\circ} \mathrm{C}$ ). As TE destas inclusões variaram de $-49,2$ a $-41,1^{\circ} \mathrm{C}$ enquanto que as $\mathrm{TH}$ variaram entre 155,1 e $380,9^{\circ} \mathrm{C}$, com moda entre 180 e $220^{\circ} \mathrm{C}$. O histograma das temperaturas de homogeneização $(\mathrm{TH})$ das inclusões fluidas da amostra MS-1 encontra-se na Figura 77. 


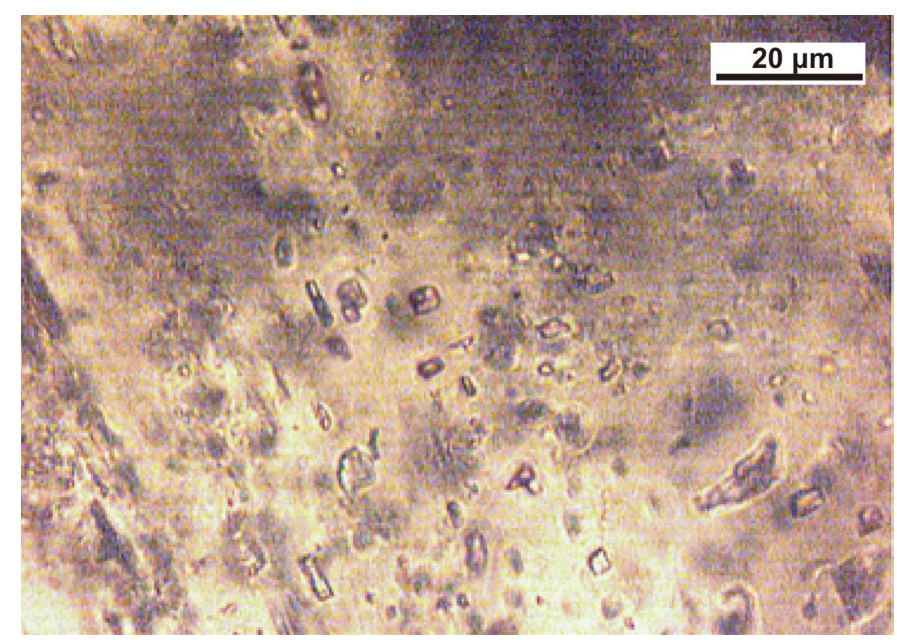

Figura 76. Detalhe da região indicada pelo número 2 na Figura 71, onde ocorrem trilhas de inclusões fluidas aquosalinas que cortam os cristais de quartzo do veio subvertical.

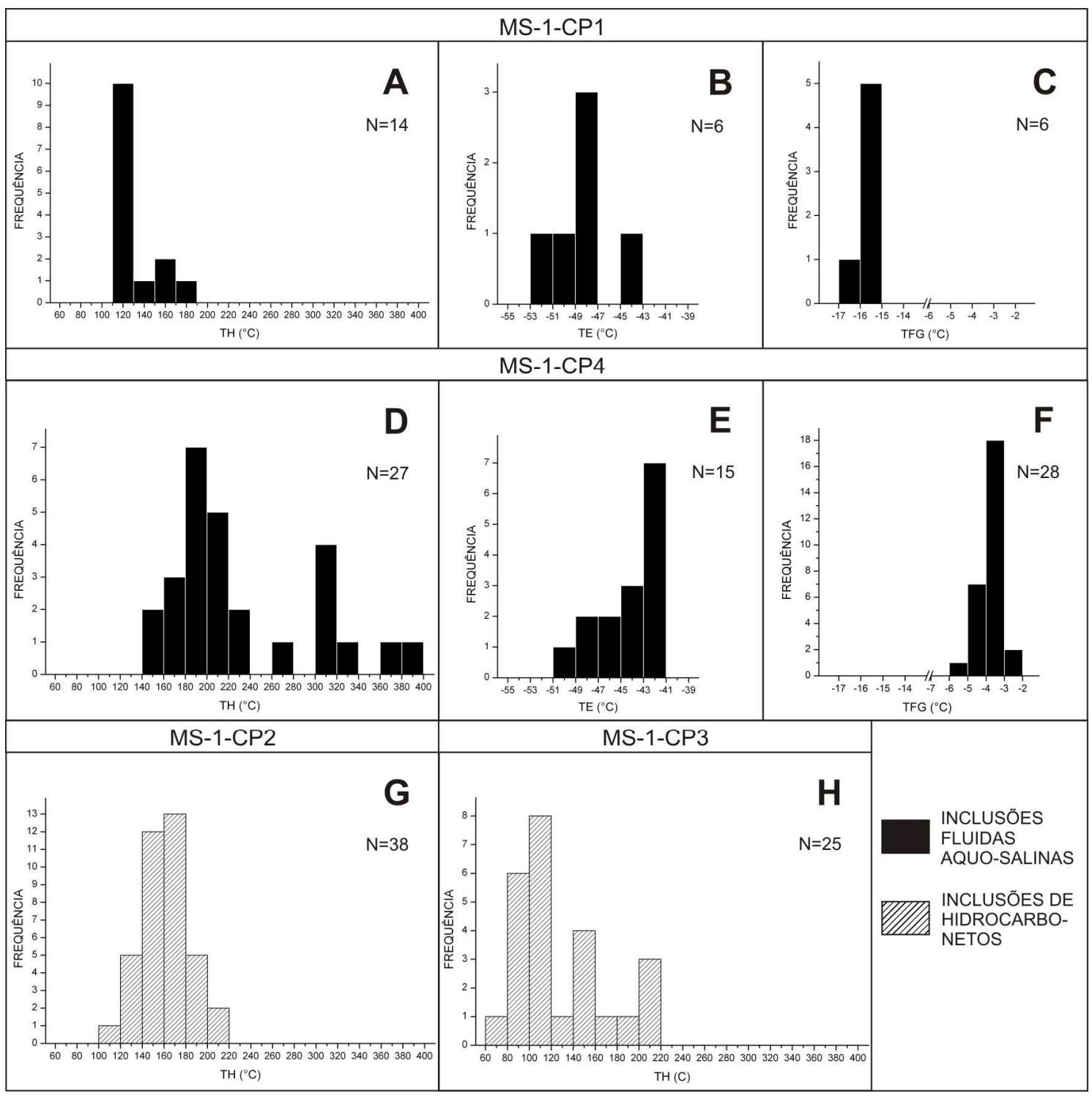

Figura 77. Distribuições de freqüência das temperaturas de homogeneização - TH (A, D), do ponto eutético - TE (B, E) e de fusão do gelo - TFG (C, F) das inclusões fluidas aquo-salinas da amostra MS-1, campos CP1 e CP4, respectivamente. TH $(\mathbf{G}, \mathbf{H})$ das inclusões fluidas de hidrocarbonetos da amostra MS-1, campos CP2 e CP3, respectivamente. 
A Tabela 2 resume os dados microtermométricos ( $\mathrm{TH}$ modal, valores mínimo e máximo de TH, TE, TFG e salinidade) obtidos a partir das análises das inclusões fluidas em minerais autigênicos (calcita e quartzo) das formações Teresina e Corumbataí e de veio em dique básico associado ao magmatismo Serra Geral.

Tabela 2. Resumo dos dados microtermométricos das análises de inclusões fluidas das formações Teresina e Corumbataí e de veio em dique básico

\begin{tabular}{|c|c|c|c|c|c|c|c|c|}
\hline \multicolumn{9}{|c|}{ RESUMO DOS DADOS MICROTERMOMÉTRICOS DE INCLUSÕES FLUIDAS } \\
\hline $\begin{array}{c}\text { Região e } \\
\text { Unidade } \\
\text { Estratigráfica }\end{array}$ & $\begin{array}{c}\text { Mineral } \\
\text { Autigênico e } \\
\text { Rocha } \\
\text { Hospedeira }\end{array}$ & Amostra & Tipo & $\begin{array}{c}\text { TH } \\
\left({ }^{\circ} \mathrm{C}\right)\end{array}$ & $\begin{array}{l}\text { Moda TH } \\
\left({ }^{\circ} \mathrm{C}\right)\end{array}$ & $\begin{array}{l}\text { TE } \\
\left({ }^{\circ} \mathrm{C}\right)\end{array}$ & $\begin{array}{l}\text { TFG } \\
\left({ }^{\circ} \mathrm{C}\right)\end{array}$ & $\begin{array}{c}\text { Salinidade } \\
\text { (\% em } \\
\text { peso de } \\
\text { NaCl eq.) }\end{array}$ \\
\hline \multirow{5}{*}{$\begin{array}{c}\text { Taguaí (SP) - } \\
\text { Formação } \\
\text { Teresina }\end{array}$} & \multirow{4}{*}{$\begin{array}{c}\text { Calcita em } \\
\text { veio beef em } \\
\text { siltito com } \\
\text { laminação } \\
\text { heterolítica }\end{array}$} & \multirow{2}{*}{ TER-03 } & \multirow{2}{*}{$\begin{array}{c}\text { aquo-salina / } \\
\text { hidrocarboneto }\end{array}$} & \multirow{2}{*}{59,5 a 131,2} & $\left.1^{\circ}\right) 60$ a 80 & \multirow{2}{*}{$-54,0$ a $-43,0$} & \multirow{2}{*}{$-18,4$ a $-11,4$} & \multirow{2}{*}{15,7 a 21,8} \\
\hline & & & & & $\left.2^{\circ}\right) 100$ a 120 & & & \\
\hline & & TER-07 & aquo-salina & 45,6 a 178,0 & 80 a 100 & $-52,5$ e $-26,8$ & $-24,7$ a $-4,9$ & 8,0 a 26,1 \\
\hline & & TER-09 & aquo-salina & 43,5 a 285,8 & 60 a 80 & $-54,5$ a $-41,3$ & $-23,8$ a $-1,3$ & 2,3 a 25,6 \\
\hline & $\begin{array}{c}\text { Calcita em } \\
\text { cavidade de } \\
\text { dissolução de } \\
\text { packstone/ } \\
\text { grainstone } \\
\text { oolítico } \\
\text { brechado } \\
\end{array}$ & IP-06-R7 & aquo-salina & 245,7 a 324,9 & 260 a 280 & $-49,6$ a $-26,0$ & $-23,3$ a $-3,2$ & 5 a 25 \\
\hline $\begin{array}{c}\text { Fartura (SP) - } \\
\text { Serra Geral }\end{array}$ & $\begin{array}{c}\text { Veio de } \\
\text { calcita em } \\
\text { dique básico } \\
\text { do } \\
\text { magmatismo } \\
\text { Serra Geral } \\
\end{array}$ & $J Z-16 A$ & aquo-salina & 81,5 a 246,2 & 140 a 160 & $-50,5$ a $-35,1$ & $-1,5$ a 3,7 & 0 a 2,6 \\
\hline $\begin{array}{l}\text { Anhembi (SP) - } \\
\text { Formação } \\
\text { Teresina }\end{array}$ & $\begin{array}{c}\text { Cristal de } \\
\text { quartzo de } \\
\text { geodo de } \\
\text { cone silicoso }\end{array}$ & IP-22B & aquo-salina & 55,8 a 177,6 & 80 a 100 & $-57,8$ a $-43,5$ & $-5,7$ a $-11,4$ & 11,3 a 15,7 \\
\hline \multirow{5}{*}{$\begin{array}{c}\text { Jacarezinho } \\
\text { (PR) - } \\
\text { Formação } \\
\text { Teresina }\end{array}$} & $\begin{array}{c}\text { Calcita de } \\
\text { fenda de } \\
\text { tração }\end{array}$ & JZ-04A & aquo-salina & 98,4 a 177,8 & 140 a 160 & $-49,1$ a $-41,2$ & $-2,7$ a $-0,5$ & 0,9 a 4,5 \\
\hline & \multirow{3}{*}{$\begin{array}{c}\text { Calcita } \\
\text { blocosa em } \\
\text { cavidade de } \\
\text { dissolução de } \\
\text { chert nodular } \\
\text { brechado }\end{array}$} & JZ-02C & aquo-salina & 199,0 a 384,8 & 240 a 260 & $-52,6$ a $-40,1$ & $-2,4$ a $-0,5$ & 1,1 a 4,1 \\
\hline & & $\mathrm{JZ}-05$ & aquo-salina & 136,8 a 286,5 & 180 a 200 & $-53,1$ a $-40,5$ & $-4,5$ a $-0,8$ & 1,4 a 7,3 \\
\hline & & $J Z-05 A$ & aquo-salina & 115,2 a 380,2 & 220 a 240 & $-55,7$ a $-41,0$ & $-2,2$ a 0 & 0 a 3,7 \\
\hline & $\begin{array}{c}\text { Calcita } \\
\text { romboédrica } \\
\text { em mudstone } \\
\text { parcialmente } \\
\text { silicificado } \\
\end{array}$ & JZ-05D & aquo-salina & 194,5 a 312,0 & 260 a 280 & $-52,7$ a $-40,5$ & 16,6 a $-3,7$ & 20,4 a 6,1 \\
\hline $\begin{array}{c}\text { Entre Santo } \\
\text { Antonio da } \\
\text { Platina e } \\
\text { Joaquim } \\
\text { Távora (PR) - } \\
\text { Formação } \\
\text { Teresina }\end{array}$ & $\begin{array}{l}\text { Calcita em } \\
\text { fratura } \\
\text { vertical }\end{array}$ & $\mathrm{JZ}-10$ & aquo-salina & 60,3 a 93,4 & 80 a 90 & & & \\
\hline \multirow{4}{*}{$\begin{array}{l}\text { Ipeúna (SP) - } \\
\text { Formação } \\
\text { Corumbataí }\end{array}$} & \multirow{4}{*}{$\begin{array}{l}\text { Veio de } \\
\text { quartzo em } \\
\text { siltito roxo } \\
\text { acinzentado }\end{array}$} & MS-1-Cp1 & aquo-salina & 111,7 a 170,7 & 110 a 130 & $-52,0$ a $-45,0$ & $-15,3$ a $-16,6$ & 19,3 a 20,4 \\
\hline & & MS-1-Cp2 & hidrocarboneto & 115,4 a 215,1 & 160 a 180 & & & \\
\hline & & MS-1-Cp3 & hidrocarboneto & 79,0 a 213,0 & 100 a 120 & & & \\
\hline & & MS-1-Cp4 & aquo-salina & 155,1 a 380,9 & 180 e 220 & $49,2 \mathrm{a}-41,1$ & $-2,8$ a $-5,3$ & 4,7 a 8,4 \\
\hline
\end{tabular}




\section{DISCUSSÕES}

\subsection{Origem dos minerais autigênicos}

\subsubsection{Calcita}

Nas rochas estudadas, a calcita autigênica ocorre de modo pervasivo como cimento ou mineral de substituição ou em fraturas e cavidades de dissolução de fácies carbonáticas ou evaporíticas (chert nodular). Esses modos de ocorrência distintos resultam do seu caráter poligenético. A calcita pode ocorrer com textura "dente de cão" em cristais que envolvem oóides, como cristais romboédricos, como calcita espática ferrosa em packstone/grainstone bioclástico, como calcita blocosa associada a calcedônia, quartzo e, por vezes, barita e dolomita no preenchimento de cavidades de dissolução de chert nodular e de packstone/grainstone oolítico. A calcita espática também ocorre em associação com cristais de zeólita, barita e celestita em camada de calcário recristalizado. Calcita de outras gerações ocorre em fraturas verticais e horizontais.

A presença de calcita "dente de cão" como envoltório de oóides pode resultar da precipitação da calcita em zona freática sob influência de água meteórica. Este tipo textural de calcita associada à baixa compactação mecânica dos grãos de oóides indica provável cimentação eodiagenética.

A calcita ferrosa tem composição típica de ambiente redutor e pode ter sido formada em soterramento mais profundo (mesodiagênese) já que apresenta-se com granulação mais grossa (coarse). O modo de ocorrência da calcita ferrosa da Formação Teresina pode corresponder a cimento gerado pela recristalização de matriz micrítica ou de calcita espática não-ferrosa sob condições de soterramento mais avançado. $O$ fato da calcita ferrosa ser cortada por veios verticais de calcita espática com deformação indica que sua cristalização seria anterior à principal fase de compactação mecânica.

Os veios horizontais de calcita fibrosa paralelos às camadas das formações Teresina e Corumbataí podem ser interpretados como veios do tipo "beef" (sensu Rodrigues et al., 2009). Esses veios são característicos de unidades sedimentares com folhelhos e mudstones ricos em matéria orgânica e sua associação com a geração de hidrocarbonetos foi proposta por Parnell \& Carey (1995), Parnell et al. (2000) e Rodrigues et al. (2009). Rodrigues et al. (2009) descrevem veios do tipo beef como sendo formados por fibras verticais de calcita oblíquas às camadas e que ocorrem no preenchimento de fraturas horizontais produzidas em zonas de expulsão 
de fluidos por sobrepressão ocasionada pela geração de hidrocarbonetos. Geminação do tipo patch (sensu Ferril et al., 2004) ocorrem nos cristais de calcita dos veios beef, na calcita blocosa de preenchimento de cavidades de dissolução de chert nodular brechado e de packstone/grainstone oolítico brechado da Formação Teresina bem como em veios verticais de diques básicos associados ao evento magmático Serra Geral. A intensidade média das geminações medidas nos beefs da Formação Teresina em Taguaí (SP) é de 18 geminações/mm e a espessura média das geminações é de $25 \mu \mathrm{m}$. Estes valores indicam deformação sob temperaturas superiores a $200^{\circ} \mathrm{C}$ (Ferril et al., 2004). A existência de estilólitos indica ainda dissolução por pressão e alto grau de compactação após a formação dos veios beef. A compactação química dos veios beef ocorreria em tempo posterior às condições de sobrepressão.

A ocorrência de veios verticais de calcita espática que cortam fácies packstone/grainstone bioclástico, veios beef e marga pode ser interpretada como resultado de fraturamento por compressão vertical devido a pressão litostática. Neste caso, o esforço $\sigma 1$ vertical estaria associado à possível carga de corpos ígneos horizontais (sils e derrames). Contudo, não se pode descartar a possiblidade do esforço $\sigma 1$ ser horizontal associado a regime transcorrente. $O$ fato dos veios verticais de calcita cortarem nódulos de calcedônia indica silicificação prévia dos calcários. Isto reforça que a fase de silicificação pervasiva teria sido anterior à principal fase de compactação mecânica e que ocorreram diversos eventos de formação de calcita espática. Além disso, estilólitos e veios verticais que cortam os veios horizontais de calcita (beefs) podem indicar a transição entre deformação dominada por condições de sobrepressão (pressão de fluidos > carga litostática) e a dominada por pressão litostática.

\subsubsection{Calcedônia e quartzo}

A calcedônia ocorre principalmente como mineral de substituição de componentes primários e como cimento em poros das fácies carbonáticas. Cristais de megaquartzo ocorrem no preenchimento de cavidades de dissolução de chert nodular brechado e de packstone/grainstone oolítico brechado, de geodos de cones silicosos e no preenchimento de fraturas subverticais.

A cimentação por sílica atuou de forma pervasiva por toda a Formação Teresina e aparentemente também na Formação Corumbataí. A silicificação teria ocorrido de forma mais intensa durante o início da compactação mecânica, na fase eodiagenética, após cimentação precoce por calcita. Isto é observado pela cimentação 
de calcedônia em poros primários de grainstone oolítico com oóides em contatos pontuais e raramente fraturados. Relações texturais também indicam que a precipitação da calcedônia ocorreu após a precipitação precoce de calcita espática com textura "dente de cão". Além disso, fósseis de troncos vegetais silicificados e pouco compactados e a preservação de matéria orgânica em chert nodular brechado também sustentam que a silicificação ocorreu durante fase eodiagenética. Faria et al. (2009) também descrevem a preservação de caules vegetais (Lycopodiopsis derbyi) pouco compactados (caules cilíndricos) devido à silicificação precoce nas formações Teresina e Corumbataí.

Feições de dissolução posteriores à silicificação ocorrem principalmente nas fácies chert nodular brechado e de packstone/grainstone oolítico brechado. Os nódulos representariam evaporitos (gipsita e anidrita) substituídos por calcedônia enquanto que fraturas e cavidades de dissolução desses evaporitos foram preenchidas principalmente por calcita blocosa. A origem primária evaporítica para os nódulos de calcedônia é interpretada por feições de deformação dúctil precoce. A ocorrência de cristais cúbicos menores que $1 \mu \mathrm{m}$ indicando possível presença de halita $(\mathrm{NaCl})$ e/ou silvinita $(\mathrm{KCl})$ reforça a existência de camadas evaporíticas. As feições de dissolução presentes nesta fácies representariam camadas evaporíticas parcialmente dissolvidas e com formação de brechas de colapso. Em algumas cavidades, precedendo a precipitação de calcita blocosa, ocorre calcedônia recoberta por cristais subeuédricos a euédricos de quartzo, cristais euédricos de barita e cristais de dolomita. Estes cristais de dolomita ocorrem de maneira isolada e são mais grossos (300 a $600 \mu \mathrm{m}$ ) que àqueles associados à dolomitização dos calcários em fase diagenética anterior a silicificação. Os cristais euédricos de megaquartzo indicam formação a partir de solução aquosa com baixa concentração de sílica (Milot, 1970), pois estes cristais necessitam de mais tempo para nuclear e crescer. Já a existência de quartzo microcristalino indicaria maior concentração de sílica na solução, o que teria proporcionado precipitação mais rápida.

Neste estudo, as relações texturais observadas entre os minerais autigênicos da Formação Teresina indicam que a precipitação sucessiva de calcedônia e quartzo foi seguida pela precipitação de dolomita, barita e calcita espática blocosa (blocky), respectivamente. Esta seqüência indicaria a precipitação desses minerais a partir da variação da composição química de fluido aquoso inicialmente enriquecido em sílica. Desta forma, assumindo-se um sistema fechado, a rápida precipitação de calcedônia a partir de fluido supersaturado em sílica permitiria o enriquecimento da solução em íons de $\mathrm{Ca}^{2+}$, e secundariamente de $\mathrm{Mg}^{2+}$, provenientes da silicificação de calcários, 
dolomitos e evaporitos durante a eodiagênese. O empobrecimento progressivo da solução em sílica $\left(\mathrm{H}_{3} \mathrm{SiO}_{4}{ }^{-}\right)$levaria à precipitação de megacristais idiomórficos de quartzo em contatos planares até que a composição química da solução se tornasse suficientemente saturada em $\mathrm{Mg}^{2+}, \mathrm{Ca}^{2+}, \mathrm{SO}_{4}{ }^{2-}$ e $\mathrm{CO}_{3}{ }^{2-}$ para precipitação de dolomita, barita e calcita.

Sabe-se que a dissolução e precipitação da sílica é controlada pela combinação da temperatura, salinidade, tipo de íons em solução e pH da solução aquosa. A solubilidade da sílica aumenta com a elevação da temperatura e do $\mathrm{pH}$. A salinidade pode aumentar (efeito salt-in) ou diminuir (efeito salt-out) a solubilidade da sílica. Os efeitos salt-in e salt-out dependem dos tipos de íons e da temperatura da solução aquosa. A maioria dos sais gera efeito salt-out, favorecendo a precipitação da sílica. Porém, este efeito decresce com o aumento da temperatura, sendo que alguns sais apresentam mudança crítica entre os efeitos salt-out e salt-in. $\mathrm{O} \quad \mathrm{Na}_{2} \mathrm{SO}_{4}$ apresenta temperatura crítica de $150^{\circ} \mathrm{C}$, a partir da qual os íons em solução contribuem para o efeito salt-in (Marshall \& Warakomski, 1980; Marshall \& Warakomski, 1982).

Minerais silicáticos e componentes biogênicos silicosos constituem as principais fontes de sílica para processos diagenéticos. A sílica biogênica diferencia-se por apresentar maior solubilidade se comparada aos minerais silicáticos. Fácies arenosas e carbonáticas da Formação Teresina apresentam espículas silicosas de esponja, as quais podem apresentar feições de dissolução ou estarem substituídas por calcita. Assim, assumindo que a maior quantidade de sílica tenha sua origem a partir da dissolução de espículas de esponja em fácies das unidades permianas na Bacia do Paraná, esta dissolução seria impulsionada por soluções alcalinas de elevada temperatura enriquecidas em sulfato derivados da dissolução de evaporitos ou da oxidação de sulfetos por bactérias fototróficas (Senko et al., 2004). Essas soluções aquosas alcalinas poderiam ser provenientes da dissolução de calcários e evaporitos da própria Formação Teresina ou da Formação Irati subjacente, a qual contém evidências de evaporitos e calcários substituídos por minerais de sílica. Isto favoreceria o efeito salt-in e a solubilização da sílica. Posteriormente, com a diminuição da temperatura a valores abaixo da temperatura crítica e enriquecimento da solução por íons, tornando-a mais salina e saturada em ácido silícico (PH baixo), ocorreria a dissolução progressiva dos calcários, dos dolomitos ou de níveis de composição dolomítica nas fácies carbonáticas, seguida da precipitação da sílica (efeito salt-out) nos poros primários e secundários das fácies da Formação Teresina. 
Desta forma, a temperatura e a concentração de sulfato nas soluções aquosas seriam os principais controladores da dissolução da sílica e da sua posterior precipitação como calcedônia e quartzo autigênicos. Considerando a silicificação dos calcários da Formação Teresina durante a eodiagênese, temperaturas elevadas requerem anomalia térmica durante a sedimentação da Formação Teresina no Neopermiano. Neste contexto, sugere-se possível ocorrência de hidrotermalismo Neopermiano.

A cristalização de quartzo euédrico em fraturas subverticais (amostra MS-1, Formação Corumbataí) durante fase tardia teria como possíveis origens da sílica: 1) dissolução da calcedônia pervasiva eodiagenética; 2) dissolução de grãos de feldspatos e quartzo das formações Pirambóia e/ou Botucatu; 3) transformação de esmectita em ilita. No primeiro caso, a feição por dissolução química (estilólito) observada em lâminas petrográficas, em nódulo silicificado, pode comprovar alguma contribuição deste mecanismo como fonte para a cristalização tardia de quartzo. A dissolução de grãos detríticos de quartzo e feldspato da Formação Botucatu foi observada por França et al. (2003) enquanto que Gesicki (2007) observou feições de dissolução em grãos de quartzo e feldspato da Formação Pirambóia. Contudo, em termos de contribuição de massa de $\mathrm{SiO}_{2}$, a transformação de esmectita em ilita deve ter sido a mais importante.

\subsubsection{Dolomita e pseudomorfos de calcita}

Os cristais romboédricos de dolomita com zoneamento composicional resultante de concentração elevada de magnésio no núcleo e bordas com composição calcítica podem corresponder à cristalização em zona de mistura de fluidos, com domínio de águas salina e meteórica, respectivamente (Flügel, 2004). Contudo, a presença de silício também foi observada nos núcleos dos romboedros, o que pode estar associado à silicificação parcial, representada por microcristais de calcedônia. As feições de corrosão que ocorrem nas bordas dos romboedros, principalmente naqueles presentes em intraclastos de wackestone bioclástico silicificado na fácies chert nodular, correspondem à possível reação com entrada de fluido contendo ácido silícico responsável pela silicificação dos calcários.

O modo de ocorrência de cristais de dolomita em lâminas onduladas na fácies de dolomito pode ser sin-deposicional. Esta origem tem sido comumente associada à ocorrência com evaporitos (Vasconcelos et al., 1995; Sanz-Montero et al., 2008). Esses níveis de dolomita teriam sua precipitação induzida por bactérias redutoras de 
sulfato. O fato desta fácies ocorrer em associação à fácies chert nodular brechado, que foi interpretada como originada de brecha de colapso de evaporitos, está de acordo com possível origem sin-deposicional associada a evaporitos.

Os cristais romboédricos de calcita que ocorrem dispersos ou formam aglomerados em lâminas onduladas na fácies mudstone parcialmente silicificado representariam pseudomorfos e evidenciariam a ocorrência pretérita de dolomita. Os pseudomorfos de calcita indicam processos de dedolomitização total, já que estão totalmente substituídos por calcita. Feições de dissolução nas bordas de diversos romboedros de calcita, possivelmente devido a silicificação dos níveis de mudstone, indica que a dedolomitização teria sido finalizada antes da silicificação pervasiva. A ocorrência de estilólitos no interior de romboedros de calcita indica ainda que a dedolomitização foi anterior à principal fase de compactação química dos calcários

Cristais romboédricos grossos (300 a $600 \mu \mathrm{m}$ ) de composição magnesiana e silicosa presentes no interior de cavidades da fácies chert nodular brechado são recobertos por calcita blocosa e podem ser produto de fluidos enriquecidos em magnésio derivados da dissolução de dolomita mais precoce (ex. sin-deposicional) seguida de silicificação. O tamanho elevado destes cristais romboédricos de dolomita associados a cristais de calcita blocosa pode resultar de processos hidrotermais. $O$ tamanho desses cristais se assemelha aos de dolomita em sela (saddle dolomite) que são caracterizados pela dimensão relativamente elevada, com centenas de micrômetros a milímetros de diâmetro, e que podem ser interpretados como de origem hidrotermal ou mesodiagenética (Flügel, 2004).

\subsubsection{Barita e celestita}

A barita que ocorre como cristais euédricos ou anédricos associados à calcita blocosa em cavidades de dissolução de chert nodular brechado apresenta relações texturais que indicam que sua cristalização ocorreu após a substituição de calcários e evaporitos por calcedônia e anterior à cristalização da calcita blocosa. Segundo Paytan et al. (2002), a barita hidrotermal comumente ocorre como cristais anédricos que formam rosetas e como cristais relativamente grossos a muito grossos. A barita também ocorre associada à cristais de celestita com bário, zeólita e calcita espática em calcário recristalizado. O bário necessário para cristalização de barita e de celestita com bário pode ter originado do fluido de poro ou da dissolução de feldspatos. Porém, nas fácies arenosas da Formação Teresina não foram observados feldspatos com feições de corrosão, assim, a fonte de bário deve ter sido externa à formação. Fácies 
de arenito com laminação heterolítica apresentam quantidade significativa de grãos de feldspato com feições de dissolução. O sulfato para precipitação de barita e de celestita com bário pode derivar da dissolução e substituição de evaporitos por calcedônia e calcita. Contudo, processos biogeoquímicos podem desempenhar papel importante no fornecimento de sulfato para a precipitação de barita. A precipitação de barita em ambientes próximos à superfície pode estar relacionada à oxidação de sulfeto por bactérias fototróficas (Senko et al., 2004). Filamentos de bactérias (biofilmes) em camadas de chert da Formação Teresina (Méndez, 2012) sugerem que a precipitação da barita da Formação Teresina pode ter sido influenciada por processos biogênicos.

\subsubsection{Zeólita (analcima)}

A analcima é um mineral do grupo das zeólitas e na Formação Teresina ocorre associada à cristais de barita, celestita e calcita espática em calcário recristalizado. Esta paragênese foi observada localmente em camada com cerca de $30 \mathrm{~cm}$ de espessura. O modo de ocorrência da analcima como cristais euédricos eqüidimensionais relacionados à cristais anédricos de barita e celestita com bário, envoltos por mosaico de calcita espática sugere recristalização da rocha pretérita.

A analcima da Formação Teresina pode ter sido produto da reação entre nível de cinzas vulcânicas e fluido aquoso alcalino enriquecido em íons de $\mathrm{Na}^{+}$e $\mathrm{Ca}^{2+}$ derivados da dissolução de camadas de evaporitos. Níveis de cinza vulcânica têm sido identificados nas unidades permianas da Bacia do Paraná (Matos et al., 2001; Santos et al., 2006; Rocha-Campos et al., 2007). Porém, estes níveis são de ocorrência restrita e espessura centimétrica. Outra hipótese para a gênese da zeólita envolve processos hidrotermais. Neste caso, fluidos hidrotermais estariam enriquecidos em silício e alumínio devido à dissolução de rochas encaixantes silicáticas, tais como chert, arenitos feldspáticos ou líticos e basaltos. Íons de $\mathrm{Na}^{+}$seriam provenientes da dissolução de camadas de sal e/ou de feldspatos das fácies arenosas da Formação Teresina ou das unidades sobrejacentes (formações Pirambóia, Botucatu e Serra Geral). No caso do sódio e alumínio serem provenientes da dissolução de rochas das formações Botucatu e Serra Geral, este hidrotermalismo seria de idade cretácea ou posterior. A origem eodiagenética para a analcima da Formação Teresina é desfavorecida, pois o fato destes cristais apresentarem estrutura cúbica indica que foram gerados a temperaturas elevadas incompatíveis com ambientes superficiais. 
Ghobarkar \& Schäf (1999) demonstram a formação de analcima cúbica a temperaturas da ordem de $300-450^{\circ} \mathrm{C}$, sob pressão de 1 kbar.

A ocorrência restrita de analcima a uma camada pode indicar que os fluidos aquosos da Formação Teresina estariam insaturados em silício e alumínio. Por isso, a precipitação de analcima ocorreria somente em áreas com camadas originalmente ricas em minerais reativos com elevado conteúdo em silício e alumínio, tais como camadas de tufos. Isto explicaria a ocorrência restrita de analcima. Assim, se o fluido em questão já estivesse supersaturado em íons de $\mathrm{Na}^{+}, \mathrm{Ca}^{2+}$ e $\mathrm{Ba}^{2+}$ derivados da dissolução de camadas de evaporitos e/ou de feldspatos, haveria a precipitação da paragênese calcita espática, analcima, barita e celestita de modo mais distribuído, sem restrição à zona de ocorrência de nível tufítico. A associação entre cristais de calcita espática, barita, celestita e analcima cúbica reforça a gênese hidrotermal, uma vez que esta paragênese é característica de fluidos aquosos de temperaturas relativamente elevadas em relação às temperaturas de sinéclises com evolução diagenética controlada apenas por soterramento.

\subsubsection{Ilita-esmectita e esmectita (saponita)}

$\mathrm{Na}$ Formação Teresina, o cimento de ilita teria se originado a partir da transformação da esmectita, já que ocorre como interestratificados de esmectita-ilita. $\mathrm{Na}$ Formação Corumbataí, foi descrita a ocorrência de ilita na forma detrítica, neoformada e originada a partir da transformação de esmectita. Ramos e Formoso (1975) relatam que a grande quantidade de ilita da Formação Corumbataí resultaria de argilominerais detríticos neomorfisados, com a geração de cristais euédricos de ilita de maior granulometria durante a diagênese (Costa, 2006).

Costa (2006) propõe que a esmectita detrítica na Formação Corumbataí teria sido transformada em ilita durante a diagênese e mediante hidrotermalismo. Para este autor, a maioria dos cristais euédricos de ilita teria origem a partir da reação de argilominerais (esmectita, caulinita e/ou palygorskita) com cátions de $\mathrm{K}^{+}$e $\mathrm{Al}^{3+}$ presentes no fluido intersticial ou percolante em zonas de fratura.

Desta forma, a transformação de esmectita em interestratificados de esmectitailita na Formação Teresina teria ocorrido devido ao aumento de temperatura e percolação de fluidos alcalinos ricos em Na+, $\mathrm{K}^{+}$e $\mathrm{Al}^{3+}$. Segundo McKinley et al. (2003), esta transformação ocorre em temperaturas entre 100 e $250^{\circ} \mathrm{C}$, sendo expressa pela seguinte reação:

$$
\text { esmectita }+\mathrm{Al}^{3+}+\mathrm{K}^{+} \rightarrow \text { ilita }+\mathrm{Si}^{4+}\left(\text { com perda de } \mathrm{Fe}, \mathrm{Mg} \mathrm{e} \mathrm{H}_{2} \mathrm{O}\right)
$$


Sugere-se como fonte dos íons de $\mathrm{K}^{+}$, a dissolução de camadas de evaporitos ou de feldspatos potássicos e micas detríticas.

As formações Teresina e Corumbataí apresentam predomínio de camadas argilosas impermeáveis ou camadas arenosas com cimentação precoce. Assim, é possível que a transformação da esmectita em ilita tenha sido dificultada devido à restrição para circulação de fluidos alcalinos, mesmo sob temperatura suficiente para a reação completa, tal como indicado pelas paleotemperaturas medidas pela análise de inclusões fluidas. Isto explica a existência de níveis com transformação incompleta de esmectita em ilita, o que resultou em interestratificados de ilita-esmectita.

A saponita, variedade de esmectita trioctaédrica, se transforma em clorita quando exposta a temperaturas elevadas, tal como a transformação de esmectita dioctaédrica em ilita. Na Formação Teresina, a preservação da saponita e a inibição da sua transformação em clorita podem ser explicadas por duas hipóteses. A primeira hipótese corresponde à mesma que explica a transformação parcial de esmectita (dioctaédrica) em ilita e que resultou apenas na ocorrência de interestratificados de esmectita-ilita: a existência de níveis impermeáveis teria impedido a circulação de fluidos com íons necessários para a transformação completa de esmectita em ilita, e do mesmo modo da saponita em clorita, mesmo sob temperaturas suficientemente elevadas para a reação. A segunda hipótese supõe que a saponita teria sido formada após o pico térmico, a partir do intemperismo de rochas vulcânicas enriquecidas em minerais máficos, tais como as derivadas do magmatismo Serra Geral.

\subsubsection{Betume sólido}

O betume identificado na Formação Teresina teria se originado após a formação dos veios beef, já que ocorre em porosidade intercristalina dos cristais de calcita que formam esses veios. O betume também ocorre em veios subverticais de direção NW a NNW em siltitos com laminação heterolítica da Formação Teresina e nos intervalos arenosos desta fácies. O caráter compacto e opaco, a baixa fluorescência e densidade maior que $1 \mathrm{~g} / \mathrm{cm}^{3}$ permite classificar o betume da Formação Teresina como impsonita (Jacob, 1989; Cardott, 1991), embora inclusões sólidas com fluorescência azul e amarela possam indicar a presença de asphaltita e ozocerita. A geração de impsonita tem sido atribuída à alteração térmica de hidrocarbonetos líquidos. De acordo com Jacob (1989), a formação de impsonita se inicia a temperaturas correspondentes à reflectância de vitrinita de $0,7 \%$. Baseado na temperatura de calibração da reflectância de vitrinita pela microtermometria de 
inclusões fluidas (Tobin \& Claxton, 2000), a geração de impsonita ocorreria em temperaturas acima de $75^{\circ} \mathrm{C}$. $\mathrm{O}$ betume que ocorre em fraturas da Formação Teresina também é similar a veios de "shungito migrado". Shungitos são materiais carbonáceos raros descritos em rochas metavulcano-sedimentares de fácies xisto-verde na Rússia (Melezhik et al., 2004). Veios de shungitos são interpretados como produto de alteração metamórfica ou hidrotermal de hidrocarbonetos líquidos (Melezhik et al., 2004). Veios de betume sólido compacto são incomuns e sua geração tem sido atribuída à alteração térmica de hidrocarbonetos líquidos por corpos magmáticos (Parnell et al. 2003, Wilson 2000). Deste modo, o betume sólido da Formação Teresina teria sido gerado pela alteração térmica de hidrocarbonetos líquidos. Isto é sugerido pela presença de inclusões fluidas de hidrocarbonetos preservados nos cristais de calcita dos veios beef. Estes hidrocarbonetos podem ser provenientes de folhelhos da Formação Irati, principal rocha geradora de hidrocarbonetos líquidos na Bacia do Paraná (Araújo et al., 2000), ou a partir de folhelhos ou mudstones ricos em matéria orgânica da Formação Teresina. A origem a partir de folhelhos da Formação Irati é dificultada pela distribuição horizontal do betume sólido em nível estratigráfico restrito. Isto é mais compatível com fonte local, dado o caráter selante da Formação Teresina.

A Figura 78 apresenta um resumo da ocorrência dos produtos autigênicos em relação aos estágios sucessivos de soterramento e de ocorrência de eventos hidrotermais em estágio diagenético precoce (Permo-Triássico) e tardio (Eocretáceo).

\begin{tabular}{|c|c|c|c|c|c|c|c|}
\hline & \multicolumn{5}{|c|}{ SOTERRAMENTO PROGRESSIVO } & SOERGUIMENTO & \multirow[b]{2}{*}{ HIDROTERMAL } \\
\hline & & MAIS ANTIGO & <----- & TEMPO & -----> & MAIS NOVO & \\
\hline Calcita "dente de cão" & - - & & & & & & \\
\hline Dolomita (até 100 um) & - & & & & & & \\
\hline Romboedro de calcita & & - & & & & & \\
\hline Calcedônia & & $-----\square$ & & & $?+--?$ & & * \\
\hline Megaquartzo & & - & & & & & $*$ \\
\hline Calcita em bloco & & & - - & & $?-----?$ & & $*$ \\
\hline Barita & & & - & & ? $-----?$ & & $*$ \\
\hline Celestita & & & $?+---?$ & & ? $-----?$ & & \\
\hline Zeólita & & & $?+---?$ & & ? $-----?$ & & $*$ \\
\hline Dolomita (>200 um) & & & --- & & & & * \\
\hline Calcita ferrosa & & & & & & - -----$]^{3}$ & \\
\hline Calcita em veio beef & & & & $\begin{array}{ll}--- \\
-1\end{array}$ & $?$ & & \\
\hline Betume & & & & & -- & & \\
\hline Calcita em veio vertical & & & & & & - ----- ? & \\
\hline Illita-Esmectita & & & & & $--\square$ & & $*$ \\
\hline Saponita & & & & & & $----\square ?$ & \\
\hline
\end{tabular}

Figura 78. Seqüência de cristalização dos produtos autigênicos identificados na Formação Teresina. 


\subsection{Paleotemperaturas}

Os veios de calcita tipo beef da Formação Teresina na região de Taguaí têm inclusões monofásicas coexistentes com inclusões bifásicas com alguma variação nas razões entre os volumes da fase vapor e da inclusão fluida. O mesmo ocorre com as inclusões secundárias em cristais de quartzo que preenchem fraturas em siltitos roxoacinzentados da Formação Corumbataí na região de Ipeúna (amostras MS-01-Cp1, MS-01-Cp2, MS-01-Cp3 e MS-01-Cp4) e com inclusões secundárias em cristais de quartzo em geodos da Formação Teresina em Anhembi (amostra IP-22B). De acordo com Goldstein e Reynolds (1994), a coexistência de inclusões fluidas monofásicas e bifásicas sugere fluidos aprisionados na zona saturada de baixa temperatura $\left(<50^{\circ} \mathrm{C}\right)$, com posterior reequilíbrio devido ao aquecimento a temperaturas mais elevadas (ver item 5.3.2). Contudo, deve-se considerar que a coexistência de inclusões monofásicas e bifásicas também pode representar diferentes gerações de fluidos aprisionados sob temperaturas distintas.

Na Formação Teresina na região de Jacarezinho, inclusões fluidas secundárias em cristais de calcita blocosa de cavidades de chert nodular brechado (amostras JZ02C, JZ-05 e JZ-05A) e inclusões pseudo-secundárias em cristais de calcita de fenda de tração (amostras JZ-04A) apresentam-se todas bifásicas com proporções semelhantes da fase vapor em relação a inclusão fluida $\left(\mathrm{V}_{\mathrm{VAP}} / \mathrm{V}_{\mathrm{IF}}\right)$. Isto também ocorre com inclusões fluidas primárias aprisionadas em cristais de calcita blocosa de cavidades de dissolução de packstone/grainstone oolítico brechado da região de Taguaí (amostra IP-06-R7) e com inclusões de calcita espática em fratura de dique básico da região de Fartura (amostra JZ016A). Isto indica que essas inclusões foram aprisionadas em zona saturada de alta temperatura $\left(>50^{\circ} \mathrm{C}\right)$ e podem ter sofrido reequilíbrios térmicos subseqüentes, os quais elevariam ainda mais suas $\mathrm{TH}$ (Goldstein e Reynolds, 1994). Contudo, não é possível excluir a hipótese das inclusões corresponderem a fluidos aprisionados em zona saturada de baixa temperatura $\left(<50^{\circ} \mathrm{C}\right)$ que passaram por reequilíbrio térmico posterior intenso. A calcita espática romboédrica na fácies mudstone parcialmente silicificado (amostra JZ-05D) também apresenta associações de inclusões fluidas primárias bifásicas. Esta calcita de substituição de romboedros de dolomita foi interpretada como sendo eodiagenética por meio de evidências texturais e composicionais. Portanto, seus fluidos teriam sido aprisionados próximos à superfície e sofreram reequilíbrio térmico posterior. No entanto, caso o caráter bifásico das inclusões seja primário e não devido exclusivamente a reequilíbrio térmico, representaria aprisionamento de fluidos superficiais de alta temperatura, ou seja, em ambiente eodiagenético hidrotermal. 
Inclusões fluidas em cristais de calcita são sensíveis a reequilíbrios quando submetidas a temperaturas mais elevadas que as de aprisionamento. Isto resulta da maior facilidade de ocorrer estiramento (stretching) nos cristais de calcita (Prezbindowski e Larese, 1987). Quando inclusões fluidas são submetidas a aquecimento por soterramento, pode ocorrer reequilíbrio térmico pelo aumento do volume das inclusões fluidas devido ao aumento relativo da pressão interna do fluido aprisionado (stretching), isto é, ocorre expansão irreversível por meio de deformação plástica. Esse processo leva ao aparecimento da fase vapor nas inclusões monofásicas ou ao aumento das razões entre os volumes da fase vapor e o da inclusão nas inclusões bifásicas. Como conseqüência deste processo, haverá aumento das temperaturas de homogeneização (Goldstein \& Reynolds, 1994), de modo que este valor deixa de ser representativo da temperatura de aprisionamento da inclusão. No entanto, a resposta das inclusões fluidas a reequilíbrios não é uniforme, produzindo associações de inclusões fluidas com significativa variação das temperaturas de homogeneização (Goldstein \& Reynolds, 1994). Goldstein (1988) demonstrou que o reequilíbrio térmico de uma associação de inclusões fluidas aquosas pode ser identificado através da observação de temperaturas de homogeneização $(\mathrm{TH})$ variáveis.

Deste modo, a extensa variação das temperaturas de homogeneização obtidas em quase todas as amostras estudadas sugere reequilíbrios das inclusões devido a aquecimento posterior ao aprisionamento do fluido.

Goldstein (1988) demonstrou que o reequilíbrio térmico de uma associação de inclusões fluidas de mesma composição (TFG constante) pode ser identificado pela variação dos valores de $\mathrm{TH}$ em relação aos valores de temperatura de fusão do gelo (TFG), de modo que o estiramento térmico da cavidade do fluido (stretching) sem escape ou repreenchimento das inclusões resultaria em valores crescentes de $\mathrm{TH}$ sem variação dos valores de TFG (Figura 79). 


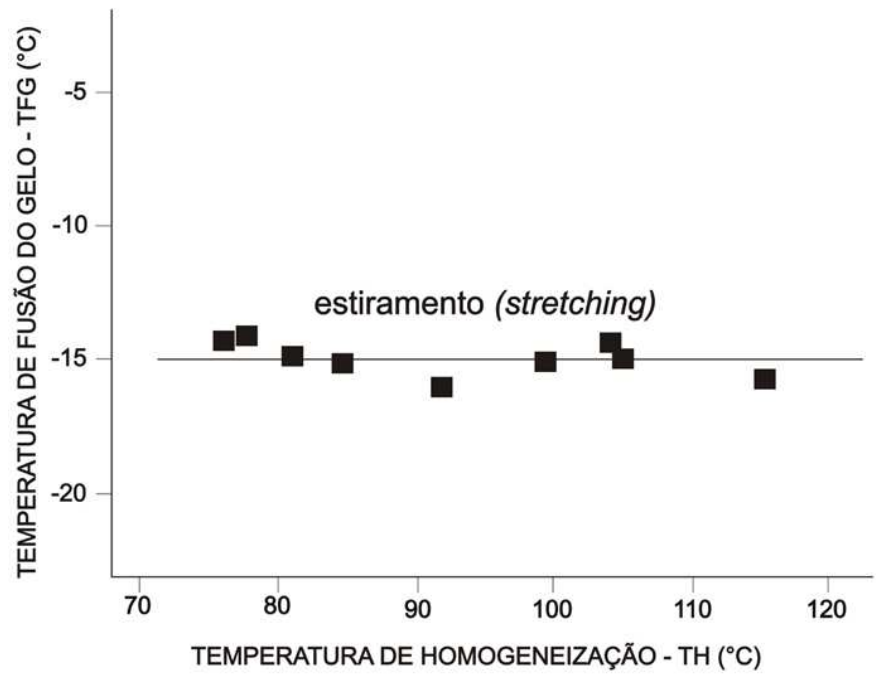

Figura 79. Padrão de variação de TH em relação a TFG diagnóstico de associação de inclusões fluidas (de mesma composição) que sofreram estiramento (stretching) por reequilíbrio térmico. Os valores de TH aumentam enquanto que os valores de TFG se mantêm constantes. Modificado de Goldstein \& Reynolds (1994).

A Figura 80 apresenta a variação das TH em relação às TFG para as inclusões fluidas medidas em calcita e quartzo das regiões de Taguaí-Fartura (amostras TER03, TER-07, TER-09, IP-06-R7 e JZ-16A), Jacarezinho (amostras JZ-05D, JZ-02C, JZ04A,JZ-05, JZ-05A), Ipeúna (amostras MS-01-Cp1 e MS-01-Cp4) e Anhembi (amostra IP-22B).

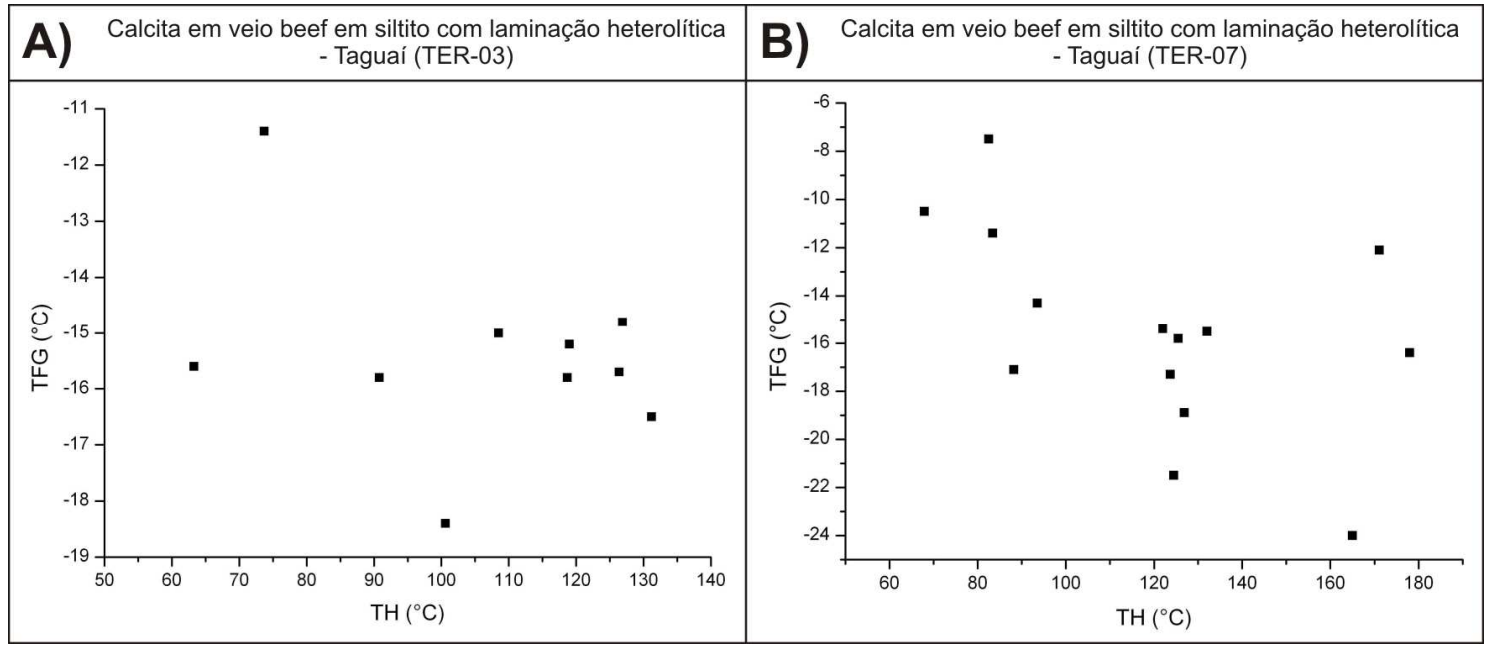




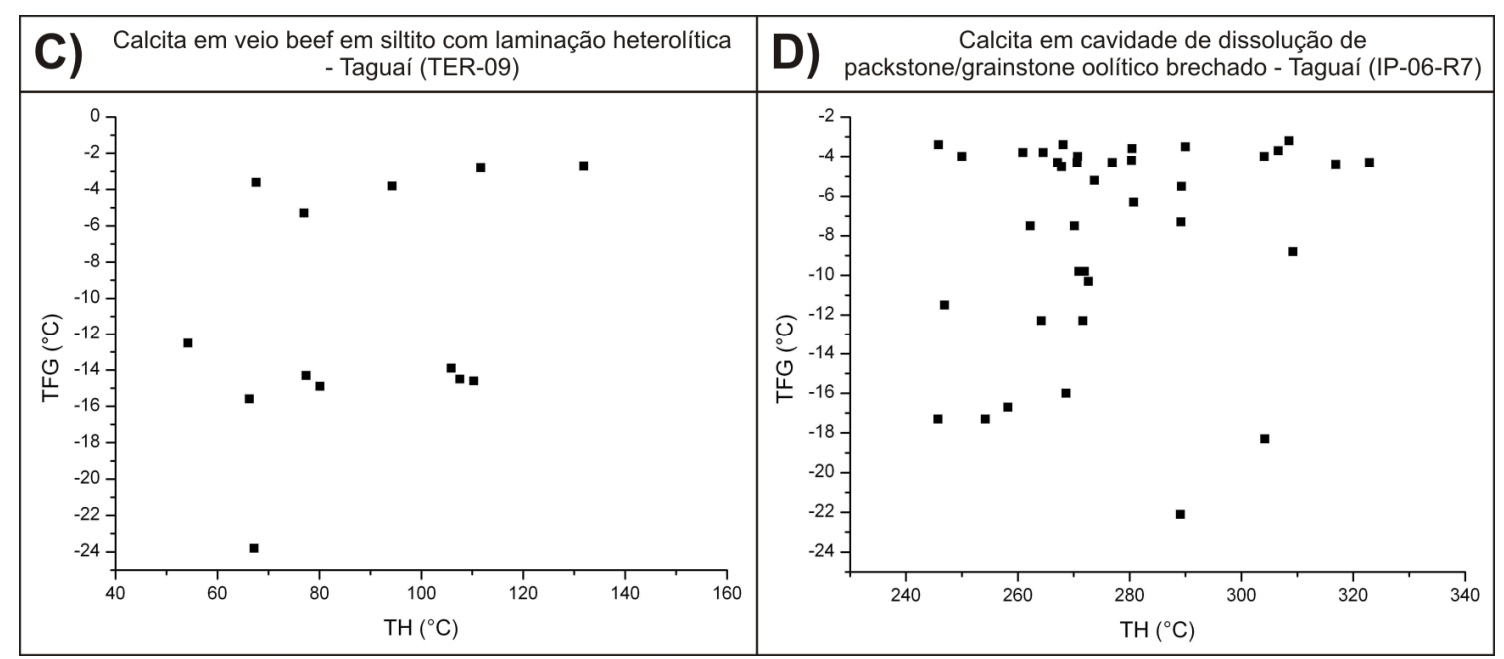
E) Veio de calcita em dique de diabásio do magmatismo
Serra Geral - Fartura (JZ-16A)

F) Calcita romboédrica em mudstone parcialmente silicificado

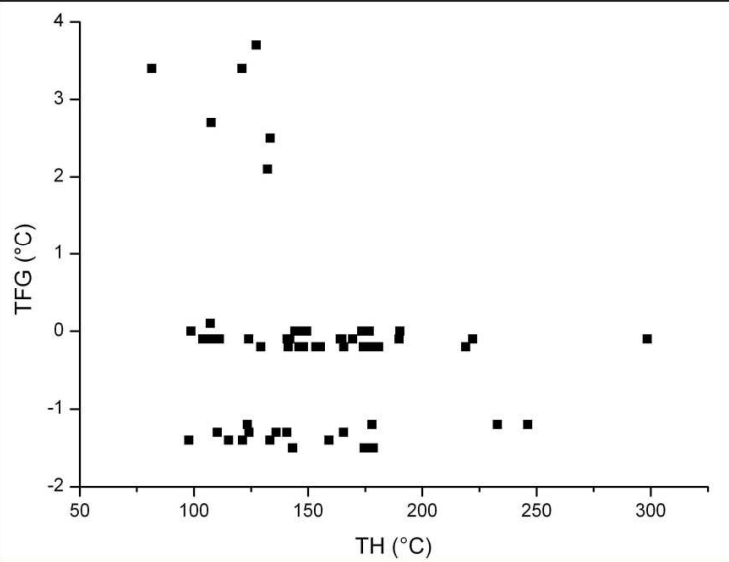
- Jacarezinho (JZ-05D)
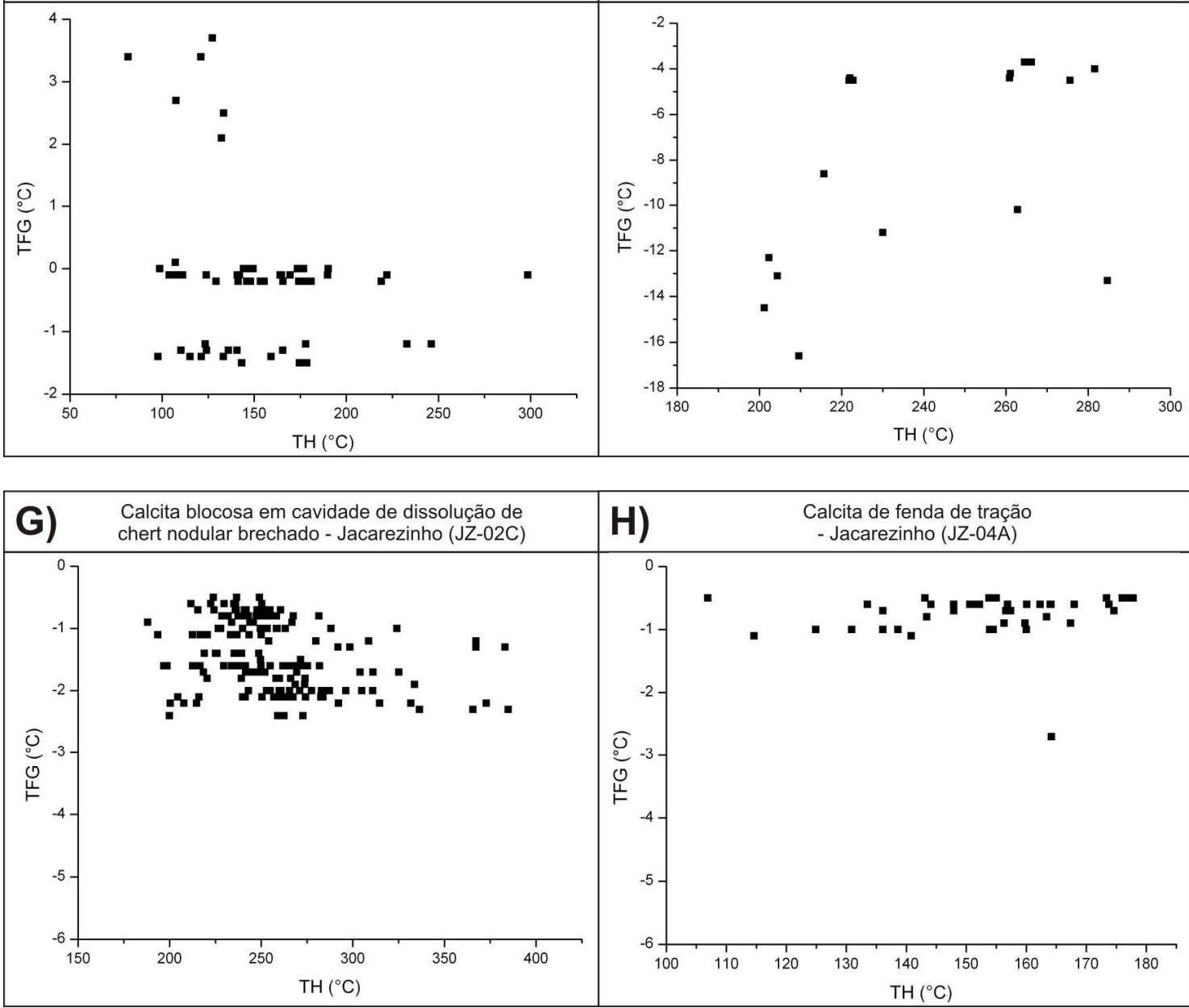

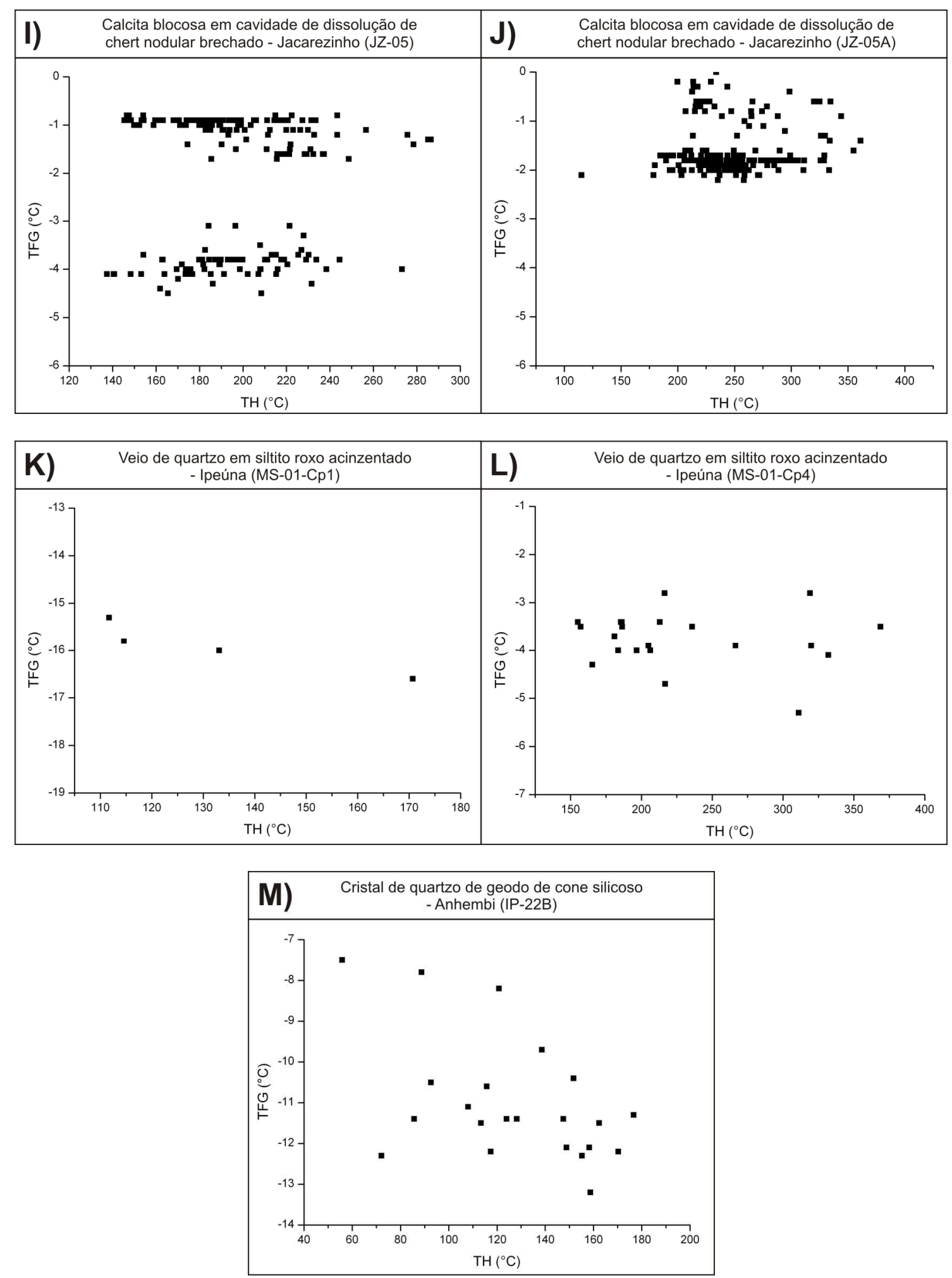

Figura 80. Gráficos de correlação entre as temperaturas de homogeneização (TH) e as temperaturas de fusão do gelo (TFG) para as amostras de calcita e quartzo das formações Teresina e Corumbataí nas regiões de Taguaí-Fartura ( $A, B, C, D$ e E), Jacarezinho (F, G, H, I e J), Ipeúna ( $K$ e L) e Anhembi (M). A amostra JZ-16A corresponde à calcita em dique básico que corta a Formação Teresina. 
A análise da variação da TH em relação à TFG demonstrou que os veios de calcita (beef) da Formação Teresina na região de Taguaí (amostras TER-03 e TER-09) possuem diversas gerações de inclusões fluidas que sofreram reequilíbrios térmicos, ou seja, cada geração de inclusões fluidas reequilibradas pode ser reconhecida pela ocorrência de valores constantes de TFG para valores crescentes de TH. Esta tendência foi observada para inclusões com TFG próximas a $-3^{\circ} \mathrm{C}$ e $-15^{\circ} \mathrm{C}$, o que implica em duas gerações de inclusões reequilibradas. A variação das $\mathrm{TH}$ em relação às TFG para inclusões em calcita de preenchimento de cavidades de dissolução em packstone/grainstone oolítico brechado (amostra IP-06-R7, Taguaí) também parece indicar a existência de pelo menos uma geração de inclusões (TFG ao redor de -2 e $4^{\circ} \mathrm{C}$ ) que sofreram reequilíbrio térmico (stretching). O veio vertical de calcita em dique básico (amostra JZ-16A, Fartura) apresenta geração de inclusões fluidas reequilibradas para valores de TFG entre 0 e $-1^{\circ} \mathrm{C}$. Em Jacarezinho, verificou-se que a calcita blocosa em cavidades de chert nodular (amostras JZ-02, JZ-05 e JZ-05A) e calcita espática de veio de fenda de tração (amostra JZ-04A) também apresentam uma geração de inclusões fluidas reequilibradas, a qual é caracterizada por TFG entre 0 e $-2^{\circ} \mathrm{C}$. Adicionalmente, a amostra JZ-05 também apresentou outra geração de inclusões fluidas reequilibradas caracterizadas por TFG próximas a -3 e $-4^{\circ} \mathrm{C}$. Nas fraturas preenchidas por cristais de quartzo na Formação Corumbataí em Ipeúna (amostras MS-01-CP1 e MS-01-CP4), foi possível identificar duas gerações de inclusões fluidas reequilibradas, sendo uma com TFG entre -3 e $-4^{\circ} \mathrm{C}$ e outra com TFG entre -15 e $-16^{\circ} \mathrm{C}$. Nos cristais de quartzo que formam geodos em cones silicosos da Formação Teresina em Anhembi (amostra IP-22B), ocorre uma geração de inclusões reequilibradas com TFG ao redor de -11 e $-12^{\circ} \mathrm{C}$. Assim, nas amostras estudadas, valores de $\mathrm{TH}$ crescentes para diversos valores relativamente constantes de TFG indicariam diversas gerações de fluidos submetidos a eventos de reequilíbrio térmico. Deste modo, as $\mathrm{TH}$ das amostras descritas anteriormente registrariam temperaturas de aquecimento posteriores ao aprisionamento dos fluidos. Contudo, uma das amostras de veio beef de Taguaí (amostra TER-07) e outra de romboedros de calcita espática de Jacarezinho (amostra JZ-05D) diferem das demais amostras estudadas por apresentarem fluidos aquosos com alta variação de salinidade em relação às $\mathrm{TH}$. Este padrão também foi observado em inclusões fluidas de calcita espática blocosa que preenche cavidades de chert e em cristais de quartzo em geodo (amostras IP-06R7 e IP-22B, Taguaí e Anhembi, respectivamente), embora para estas amostras foi possível reconhecer pelo menos uma geração de inclusões que sofreram reequilíbrio (stretching). Assim, os fluidos aquosos com alta variação da TFG em relação às TH poderiam ser explicados por três hipóteses: 1) abertura das cavidades e troca de 
fluidos durante eventos de reequilíbrio térmico. Uma vez que os processos de reequilíbrio atingem as inclusões de modo diferente, algumas inclusões podem ter sofrido maior aumento de suas pressões internas, o que ocasionaria abertura, escape de fluidos e repreenchimento; 2) aprisionamento progressivo de mistura de fluidos com salinidades distintas; 3) aprisionamento de fluidos de gerações diferentes, formando inclusões primárias e secundárias de difícil distinção petrográfica.

Inclusões fluidas em calcita que preenche fratura vertical da Formação Teresina em Joaquim Távora (amostra JZ-10) são bifásicas à temperatura ambiente, com o volume da fase vapor menor que $10 \%$ do volume da inclusão. Contudo, não foi possível comparar os dados de TH e TFG para avaliar a existência de reequilíbrio por stretching, pois os valores de TFG não puderam ser adquiridos. Isto ocorreu devido ao desaparecimento das bolhas durante o resfriamento, sem retorno das mesmas durante reaquecimento até temperaturas iguais ou maiores que $0^{\circ} \mathrm{C}$. Este comportamento indica metaestabilidade. Isto é característico do aprisionamento de fluidos pouco salinos à temperaturas baixas ou moderadas $\left(<50^{\circ} \mathrm{C}\right)$ em inclusões de dimensões reduzidas e com bolhas diminutas (Roedder, 1984).

Experimentos de aquecimento que simulam reequilíbrios térmicos em calcita demonstram significativo aumento das $\mathrm{TH}$, com os valores mais elevados próximos à temperatura de máximo aquecimento a que os cristais de calcita foram submetidos (Prezbindowski \& Larese, 1987). Desta forma, é possível estimar as temperaturas de aquecimento dos cristais autigênicos estudados e de suas rochas hospedeiras nas formações Teresina e Corumbataí. Para isto, os valores mais altos de TH representariam estimativas das paleotemperaturas de reequilíbrio atingidas após a cristalização da calcita e quartzo estudados, ou seja, corresponderiam à máxima temperatura de aquecimento desses cristais. Contudo, neste estudo, os valores de $\mathrm{TH}$ mais elevados e que apresentam número significativo de medidas (classe acima da moda com pelo menos $10 \%$ dos valores medidos) foram considerados como estimativas mínimas das paleotemperaturas de máximo reequilíbrio térmico, já que os valores máximos das $\mathrm{TH}$ apresentaram quantidade de dados insuficientes para serem assumidos como estimativas robustas de paleotemperaturas. Assim, esses valores máximos de $\mathrm{TH}$ com baixa representatividade estatística podem corresponder tanto a valores próximos à temperatura máxima de aquecimento quanto a valores anômalos (outliers) decorrentes da imprecisão durante a microtermometria, como exemplo, a dificuldade em observar mudanças de fase em inclusões de tamanho reduzido ou a ocorrência do processo de necking down não diagnosticada (ver item 5.3.1). Desta forma, as $\mathrm{TH}$ de reequilíbrio das inclusões fluidas dos veios beef da Formação 
Teresina (amostras TER-03, TER-07 e TER-09) indicam que a rocha teria sido aquecida a temperaturas de pelo menos $130^{\circ} \mathrm{C}$, que corresponde a temperatura de homogeneização mais elevada com número significativo de medidas entre os veios estudados. Contudo, destaca-se que temperaturas acima de $200^{\circ} \mathrm{C}$ também foram registradas em todos esses veios e que estão de acordo com as temperaturas de deformação estimadas pelas geminações da calcita. As inclusões fluidas presentes em calcita espática de fenda de tração da Formação Teresina em Jacarezinho (amostra JZ-04A) indicam aquecimento a temperatura mínima de $170^{\circ} \mathrm{C}$. Temperaturas de aquecimento próximas a este valor foram registradas para os fluidos presentes em cristais de quartzo de geodos da Formação Teresina na região de Anhembi (SP), cuja temperatura mínima de aquecimento seria representada por valores significativos de $\mathrm{TH}$ próximos a $150^{\circ} \mathrm{C}$ (amostra IP-22B). Contudo, a ocorrência de valores que ultrapassam $200^{\circ} \mathrm{C}$ também foi observada. As inclusões fluidas da calcita blocosa em cavidades de chert nodular brechado em Jacarezinho (amostras JZ-02C, JZ-05 e JZ05A), de calcita espática de cavidades em grainstone oolítico em Taguaí (amostra IP06-R7) e dos cristais romboédricos de calcita que ocorrem em Jacarezinho (amostra JZ-05D) registrariam as maiores temperaturas de aquecimento da Formação Teresina observadas neste estudo. Estas temperaturas são representadas por valores ao redor de $270^{\circ} \mathrm{C}$ (amostras JZ-02C, JZ-05, JZ-05D e JZ-05A) e $290^{\circ} \mathrm{C}$ (amostra IP-P6-R7), porém com a ocorrência de temperaturas até $400^{\circ} \mathrm{C}$. As inclusões fluidas de quartzo que preenche fraturas na Formação Corumbataí em Ipeúna (SP) registram as maiores temperaturas de aquecimento estimadas para esta formação neste estudo, com pelo menos $190^{\circ} \mathrm{C}$ (valores mais significativos) e valores máximos de até $400^{\circ} \mathrm{C}$ (amostra MS-1-Cp4). A calcita espática em veio de dique básico apresenta inclusões fluidas que indicaram aquecimento dos cristais a pelo menos $170^{\circ} \mathrm{C}$. A Tabela 3 sintetiza as paleotemperaturas estimadas para as formações Teresina e Corumbataí nas áreas estudadas. 
Tabela 3 - Estimativa da mínima temperatura (maiores valores significativos das temperaturas de homogeneização por reequilíbrio térmico de inclusões fluidas) correspondente ao máximo aquecimento a que as inclusões fluidas foram submetidas, e portanto seus minerais autigênicos e rochas hospedeiras.

\begin{tabular}{|c|c|c|}
\hline $\begin{array}{l}\text { Região e unidade } \\
\text { estratigráfica }\end{array}$ & $\begin{array}{l}\text { Mineral autigênico } \\
\text { e rocha hospedeira }\end{array}$ & $\begin{array}{c}\text { Estimativa da temperatura } \\
\text { mínima do pico térmico a } \\
\text { que os minerais } \\
\text { autigênicos e rochas } \\
\text { hospedeiras foram } \\
\text { submetidos }\left({ }^{\circ} \mathrm{C}\right)\end{array}$ \\
\hline $\begin{array}{l}\text { Ipeúna (SP), } \\
\text { Formação Corumbataí }\end{array}$ & $\begin{array}{l}\text { Veio de quartzo em siltito } \\
\text { roxo-acinzentado } \\
\text { (amostra MS-1) }\end{array}$ & 190 \\
\hline $\begin{array}{l}\text { Anhembi (SP), } \\
\text { Formação Teresina }\end{array}$ & $\begin{array}{l}\text { Quartzo em geodo de cone } \\
\text { silicoso (amostra IP-22B) }\end{array}$ & 150 \\
\hline $\begin{array}{l}\text { Taguaí (SP), } \\
\text { Formação Teresina }\end{array}$ & $\begin{array}{c}\text { Calcita em veio beef em siltito } \\
\text { com laminação heterolítica } \\
\text { (amostras TER-03, TER-09 e } \\
\text { TER-07) }\end{array}$ & 130 \\
\hline $\begin{array}{l}\text { Taguaí (SP), } \\
\text { Formação Teresina }\end{array}$ & $\begin{array}{c}\text { Calcita em cavidade de } \\
\text { dissolução de } \\
\text { packstone/grainstone oolítico } \\
\text { brechado (amostra IP-06-R7) }\end{array}$ & 290 \\
\hline $\begin{array}{c}\text { Fartura (SP), dique do } \\
\text { magmatismo Serra } \\
\text { Geral }\end{array}$ & $\begin{array}{l}\text { Veio de calcita em dique } \\
\text { básico (amostra JZ-16A) }\end{array}$ & 180 \\
\hline $\begin{array}{l}\text { Jacarezinho (PR), } \\
\text { Formação Teresina }\end{array}$ & $\begin{array}{l}\text { Calcita blocosa em cavidade } \\
\text { de dissolução de chert nodular } \\
\text { brechado (amostras JZ-05, } \\
\text { JZ-05A e JZ-02C) }\end{array}$ & 270 \\
\hline $\begin{array}{l}\text { Jacarezinho (PR), } \\
\text { Formação Teresina }\end{array}$ & $\begin{array}{c}\text { Calcita romboédrica em } \\
\text { mudstone parcialmente } \\
\text { silicificado } \\
\text { (amostra JZ-05D) }\end{array}$ & 270 \\
\hline $\begin{array}{l}\text { Jacarezinho }(\mathrm{PR}) \text {, } \\
\text { Formação Teresina }\end{array}$ & $\begin{array}{l}\text { Calcita em fenda de tração em } \\
\text { arenito muito fino intercalado a } \\
\text { siltito com laminação } \\
\text { heterolítica (amostra JZ-04) }\end{array}$ & 170 \\
\hline $\begin{array}{l}\text { Santo Antonio da } \\
\text { Platina - Joaquim } \\
\text { Távora (PR), } \\
\text { Formação Teresina }\end{array}$ & $\begin{array}{l}\text { Calcita em fratura vertical em } \\
\text { siltito (amostra JZ-10) }\end{array}$ & 90 \\
\hline
\end{tabular}

\subsection{Composição e origem dos paleofluidos}

Os veios beef da Formação Teresina em Taguaí compreendem fluidos contemporâneos à cristalização dos veios, aprisionados como inclusões fluidas primárias, e fluidos mais tardios aprisionados em inclusões fluidas secundárias. Esses fluidos apresentam salinidade baixa a alta ( 2 a $26 \%$ em peso equivalente de $\mathrm{NaCl}$ ) e 
estão associados a hidrocarbonetos. Apesar da presença de fluidos de baixa salinidade, fluidos de alta salinidade (moda entre 17 e $21 \%$ em peso equivalente de $\mathrm{NaCl}$ ) dominam as associações de inclusões fluidas em veios beef. A predominância de inclusões fluidas secundárias de alta salinidade (moda entre 9 a 15\% em peso equivalente de $\mathrm{NaCl}$ ) também foi observada em cristais de quartzo de geodos da Formação Teresina em Anhembi (amostra IP-22B). Calcita blocosa em cavidades de dissolução de packstone/grainstone oolítico brechado da Formação Teresina (amostra IP-06-R7) também apresentou inclusões fluidas primárias com salinidade moderada a elevada ( 6 a $25 \%$ em peso equivalente de $\mathrm{NaCl}$ ). A ampla variação de salinidade na mesma associação de inclusões fluidas poderia resultar de inclusões parcialmente ou completamente repreenchidas durante eventos de reequilíbrios térmicos ou corresponder a inclusões de diferentes gerações de fluidos, mas com difícil distinção durante a análise petrográfica.

Calcita espática de substituição de romboedros de dolomita em Jacarezinho (amostra JZ-05D) apresenta inclusões fluidas primárias com salinidade entre 20 e 6\% em peso equivalente de $\mathrm{NaCl}$. Uma vez que esta calcita espática foi interpretada como produto de dedolomitização eodiagenética, a elevada variação da salinidade é compatível com zona de mistura de água salina e meteórica, onde se daria este processo de dedolomitização. Contudo, isto não exclui a possibilidade de que algumas inclusões fluidas primárias tenham sido abertas e repreenchidas durante eventos de reequilíbrios térmicos.

Inclusões fluidas secundárias com salinidade relativamente baixa estão presentes em calcita de fratura vertical em dique básico (amostra JZ-16A) da região de Fartura ( 0 a $3 \%$ em peso equivalente de $\mathrm{NaCl}$ ) e em calcita das cavidades de dissolução de chert nodular brechado (amostras JZ-02C, JZ-05 e JZ-05A) em Jacarezinho $(1,0$ a 4,0\% em peso equivalente de $\mathrm{NaCl}$ ). Inclusões fluidas pseudosecundárias em calcita de fenda de tração em Jacarezinho também apresentam fluidos com baixa salinidade (1 a 4,5\% em peso equivalente de $\mathrm{NaCl}$, amostra JZ04A). A salinidade baixa destes paleofluidos indicaria reduzida interação rocha-fluido e predomínio de água meteórica.

Na Formação Corumbataí em Ipeúna, fluidos aquosos e hidrocarbonetos teriam percolado veios subverticais de quartzo de direção WNW a NW (amostras MS-1-Cp1, MS-1-Cp2, MS-1-Cp3 e MS-1-Cp4) e teriam sido aprisionados como inclusões fluidas secundárias durante cicatrização de fraturas. Essas inclusões registram a percolação de duas gerações de fluidos, uma de salinidade moderada $(4,7$ e $8,4 \%$ em peso equivalente de $\mathrm{NaCl}$ ) e outra de salinidade elevada (11 a $15 \%$ em peso equivalente 
de $\mathrm{NaCl}$ ). Assim, duas gerações de fluidos aquo-salinos e hidrocarbonetos teriam percolado fraturas da Formação Corumbataí, após a cristalização dos veios de quartzo.

A composição dos paleofluidos aquosos é dada pela temperatura do ponto eutético (TE) das soluções. Esta temperatura corresponde à formação do primeiro líquido que aparece após o aquecimento da inclusão apenas pela troca de calor com o ambiente a partir de sua temperatura de congelamento. Esta mudança de fase é reconhecida pela mudança textural da solução aquosa congelada quando observada ao microscópio. Em todas as regiões de estudo foram observadas TE cujos valores estão entre -57 e $-40^{\circ} \mathrm{C}$, o que indica a presença do íon $\mathrm{Ca}^{2+}$ e/ou $\mathrm{Mg}^{2+}$ (Roedder, 1984; e Goldstein \& Reynolds, 1994). Roedder (1984) e Goldstein \& Reynolds (1994) discutem que temperaturas do ponto eutético inferiores a $-40^{\circ} \mathrm{C}$ são indicativas da existência de um íon bivalente $\left(\mathrm{Ca}^{2+}\right.$ e/ou $\left.\mathrm{Mg}^{2+}\right)$ e sugere a presença de um sistema composto por $\mathrm{H}_{2} \mathrm{O}+\mathrm{NaCl}$ com $\mathrm{CaCl}_{2}\left(\right.$ ou $\mathrm{MgCl}_{2}$ ) na solução. Contudo, em muitos casos, não foi possível observar com clareza a continuidade na mudança textural da solução congelada e, portanto, pode-se apenas sugerir a possibilidade da presença de $\mathrm{CaCl}_{2}$ e $\mathrm{MgCl}_{2}$ na solução. Segundo Goldstein \& Reynolds (1994), essas mudanças devem ser contínuas para indicarem pontos eutéticos, caso contrário, podem tratar-se apenas de recristalizações de fases sólidas. A presença dos íons de cálcio nas inclusões fluidas em calcita é comum devido à possível troca iônica entre o fluido e o mineral hospedeiro (Crawford \& Hollister, 1992), o que não reflete necessariamente a composição do fluido original. Particularmente na região de Taguaí, além da presença de inclusões fluidas compostas pelo sistema $\mathrm{H}_{2} \mathrm{O}+\mathrm{NaCl}$ com $\mathrm{CaCl}_{2}$ (ou $\mathrm{MgCl}_{2}$ ), também foram registradas inclusões fluidas cujos valores de TE ficaram compreendidos no intervalo entre -35 e $-25^{\circ} \mathrm{C}$, o que indica apenas a presença de $\mathrm{NaCl}$ em solução. De acordo com dados obtidos por Davis et al. (1990), discutidos em Goldstein \& Reynolds (1994), a temperatura eutética estável do sistema $\mathrm{H}_{2} \mathrm{O}+\mathrm{NaCl}$ é $-21,2^{\circ} \mathrm{C}$, embora essas temperaturas possam se estender até $-35^{\circ} \mathrm{C}$.

Os hidrocarbonetos na Formação Teresina apresentaram fluorescência em tons de azul (amostra TER-03), enquanto que os da Formação Corumbataí apresentaram tons de branco, azul e amarelo-laranja, o que indica variação do grau API (amostras MS-1-Cp2 e MS-1-Cp3). Segundo Goldstein e Reynolds (1994), inclusões em tons de branco e azul representam óleos leves, com grau API entre 40 e $50^{\circ}$ enquanto que tons de amarelo-laranja indicam óleos de grau API baixo a moderado (API $15-30^{\circ}$ ). Análises de espectroscopia Raman indicaram que as inclusões de óleo da Formação Teresina são formadas por hidrocarbonetos saturados 
e testes com platina de esmagamento indicaram a presença de hidrocarbonetos gasosos (C1-C4). Além disso, na Formação Corumbataí, as inclusões de hidrocarboneto de cor amarela que não fluoresceram (Figura 73B) podem caracterizar hidrocarbonetos ultrapesados. Isto pode indicar que houve degradação de hidrocarbonetos leves por ação bacteriana ou por oxidação, devido à abertura das inclusões sob a presença de fluidos aquosos meteóricos tardios (baixa salinidade). $O$ fato das inclusões de hidrocarbonetos e das inclusões aquosas associadas terem sido reequilibradas indica migração dos hidrocarbonetos em período anterior ou concomitante ao último evento de reequilíbrio térmico.

\subsection{Eventos hidrotermais nas formações Teresina e Corumbataí}

A precipitação seqüencial de quartzo, dolomita, barita e calcita em cavidades de dissolução de chert nodular brechado e de packstone/grainstone oolítico brechado teria ocorrido logo após a substituição dos calcários e evaporitos por calcedônia durante a eodiagênese. A silicificação pervasiva precoce, que requer temperaturas elevadas para produção de fluidos com alta concentração de sílica, implica circulação de fluidos aquosos aquecidos durante a eodiagênese da Formação Teresina. Isto sugere que a paragênese quartzo-dolomita-barita-calcita presente nas cavidades do chert nodular também resulta desses fluidos aquosos aquecidos. Fluidos superficiais quentes ricos em sulfato podem aumentar a solubilidade da sílica pelo efeito salt-in. Sulfatos podem ser derivados da dissolução de fácies evaporíticas da Formação Teresina. Contudo, a baixa permeabilidade das fácies evaporíticas dificultaria a sua dissolução e fornecimento de sulfato para as soluções aquosas. Soma-se a isto o fato dos evaporitos terem sido substituídos por calcedônia, o que requer a existência prévia de fluidos ricos em sílica. Logo, os evaporitos seriam fonte secundária de sulfatos. A ascensão de fluidos profundos ricos em enxofre podem gerar águas superficiais ricas em sulfato mediante oxidação. A oxidação de sulfeto e produção de sulfato em águas superficiais pode ocorrer por meio da atividade de bactérias fototróficas (Senko et al., 2004). A ocorrência de pirita associada a barita em camada de calcário recristalizado (Figura 41) e a presença de filamentos de bactérias em chert da Formação Teresina (Méndez, 2012) é compatível com a geração de sulfatos por oxidação bacteriana. A ocorrência de analcima eqüidimensional isótropa de alta temperatura (Ghobarkar \& Schäf, 1999), associada com barita, celestita e calcita espática blocosa (amostra JZ13C) em calcário recristalizado, também sugere circulação de fluidos aquosos com temperaturas elevadas. Se esta barita tiver origem relacionada à barita precoce das cavidades de chert nodular brechado, a recristalização dos calcários e formação da 
paragênese analcima-barita-celestita-calcita espática reforçaria a ocorrência de fluidos aquosos superficiais de temperaturas elevadas. Estas evidências indicam a existência de um sistema hidrotermal contemporâneo à sedimentação e eodiagênese da Formação Teresina durante o Permiano. Este sistema hidrotermal permiano seria de abrangência regional de poderia estar ligado ao campo de paleogêisers identificado na região de Anhembi (SP) por Yamamoto et al. (2005).

Inclusões fluidas de veios de calcita e quartzo presentes nas formações Corumbataí e Teresina e em dique básico associado ao magmatismo Serra Geral $(134,7 \pm 1 \mathrm{Ma}$, Thiede \& Vasconcelos, 2010) apresentaram temperaturas de homogeneização acima de $200^{\circ} \mathrm{C}$. Estas temperaturas resultam de reequilíbrios térmicos e registrariam eventos de aquecimento posteriores à cristalização da calcita e quartzo. Isto justifica a interpretação de que as elevadas temperaturas de homogeneização medidas nas inclusões fluidas estudadas registram a ocorrência de evento térmico tardio em relação ao hidrotermalismo permiano responsável pela silicificação pervasiva. Este evento térmico tardio promoveu a migração de fluidos aquosos e hidrocarbonetos, os quais encontram-se aprisionados como inclusões fluidas primárias e secundárias de veios de calcita e quartzo. O registro de temperaturas próximas a $200^{\circ} \mathrm{C}$ em inclusões fluidas presentes em veio de calcita de dique básico associado ao magmatismo Serra Geral (amostra JZ-16A) indica que este episódio térmico teria ocorrido durante o eocretáceo ou em período posterior, portanto, sem relação com o evento hidrotermal permiano. Nas áreas de estudo, as rochas sobrepostas às formações Teresina e Corumbataí têm espessura estimada menor que $1500 \mathrm{~m}$ (Milani et al., 2007). Desta forma, assumindo temperatura superficial de $20^{\circ} \mathrm{C}$ e gradiente geotérmico entre 20 e $30^{\circ} \mathrm{C} / \mathrm{Km}$, o aquecimento devido ao soterramento das unidades permianas não teria sido suficiente para alcançar temperaturas maiores que $200^{\circ} \mathrm{C}$ (em alguns casos até próximo de $400^{\circ} \mathrm{C}$ ), tal como registrado pelas temperaturas de homogeneização das inclusões fluidas. Assim, as paleotemperaturas registradas, associadas à observação de hidrocarbonetos líquidos leves em veios horizontais de calcita da Formação Teresina e em veios de quartzo da Formação Corumbataí, refutam a hipótese de história térmica controlada somente pelo soterramento dessas formações na área estudada. Apesar da discordância TriássicoJurássico ser registrada na borda nordeste da Bacia do Paraná, uma profundidade de soterramento capaz de aquecer as formações Teresina e Corumbataí em temperaturas maiores que $200^{\circ} \mathrm{C}$ implica na remoção de no mínimo $3 \mathrm{~km}$ de rochas sobrepostas à estas formações. Segundo Sant'anna et al. (2006), as unidades permianas da Bacia do Paraná foram afetadas pela circulação de fluidos hidrotermais 
durante o magmatismo Serra Geral. Costa (2006) descreve a ocorrência de veios de quartzo e carbonatos em fraturas subverticais que cortam siltitos da Formação Corumbataí em Rio Claro (SP), os quais seriam produto de hidrotermalismo ligado ao evento magmático Serra Geral. Segundo este autor, esses veios apresentam porção externa, em contato com a rocha hospedeira, constituída por cristais de quartzo perpendiculares à parede do veio. Estes cristais possuem aspecto "sujo" (impuro) dado pela concentração de inclusões fluidas e de óxido de ferro. A porção interna é formada por cristais de quartzo límpidos de contorno nítido e associados a cristais de calcita e clorita. Esta descrição se assemelha aos veios de quartzo da Formação Corumbataí analisados neste estudo (ponto MS-1), os quais foram coletados em Ipeúna (SP), município adjacente ao da ocorrência dos veios descritos por Costa (2006). Desta forma, os veios de quartzo estudados que cortam os siltitos da Formação Corumbataí em Ipeúna (SP) resultariam do mesmo fluido hidrotermal que gerou os veios de quartzo com carbonatos descritos por Costa (2006) em Rio Claro (SP).

Os minerais autigênicos e paleofluidos registrados nas formações Teresina e Corumbataí seriam produto de pelo menos dois eventos hidrotermais, um atuante durante o Permiano e outro durante o Eocretáceo, sendo ambos de abrangência regional.

\subsection{Eventos hidrotermais nas formações Teresina e Corumbataí no contexto da evolução tectônica da Bacia do Paraná}

Os produtos hidrotermais identificados nas formações Teresina e Corumbataí implicam a existência de eventos geológicos capazes de gerar anomalia térmica e caminhos para ascensão de fluidos aquosos profundos. Este sistema hidrotermal apresentaria dois períodos principais de atividade, sendo um no final do Permiano e outro no Eocretáceo. A migração de fluidos profundos até a superfície ocorreria ao longo de zonas de falhas regionais, dado a ampla distribuição dos produtos hidrotermais. Os alinhamentos Guapiara (NW), Rio Paranapanema (WNW), Rio MogiGuaçu (NNW) (Zalán et al., 1987), a falha da Jacutinga (NE) (Soares, 1991) e os altos estruturais de Jacarezinho, Neblina, Anhembi-Piapara e Pitanga (Riccomini, 1997) são as principais estruturas que moldam o arcabouço estrutural da Bacia do Paraná nas áreas estudadas. As regiões de Anhembi e Ipeúna encontram-se nas proximidades da falha da Jacutinga e do alinhamento do Rio Moji-Guaçu enquanto que as regiões de Jacarezinho e Fartura-Taguaí estão localizadas no flanco norte do Arco de Ponta 
Grossa, sobre o alinhamento de Guapiara, próximo ao cruzamento deste com a falha da Jacutinga. Destaca-se ainda que as localidades estudadas encontram-se nas áreas dos altos estruturais de Jacarezinho, Neblina (Fartura e Taguaí), Anhembi-Piapara e Pitanga (Ipeúna). As descontinuidades (falhas e juntas) associadas a estas estruturas definem os caminhos de percolação de fluidos nas unidades da Bacia do Paraná, sendo particularmente importantes para circulação de fluidos em unidades dominadas por rochas de baixa permeabilidade, tais como as formações Teresina e Corumbataí. A circulação de fluidos hidrotermais seria favorecida durante os períodos de geração ou reativação de falhas profundas. Neste caso, destaca-se a reativação de falhas da Bacia do Paraná durante o final do Permiano (Rostirolla et al., 2000; Stollhofen et al., 2000; Riccomini et al., 2005), Eocretáceo e Neocretáceo-Terciário (Riccomini, 1997; Strugale et al., 2007). Neste contexto, as falhas da Jacutinga (NNE, NE) e de Guapiara (NNW, NW) seriam as principais estruturas regionais capazes de promover a circulação de fluidos hidrotermais na borda leste da Bacia do Paraná (Figura 81). Em geral, as formações Teresina e Corumbataí em todas as regiões estudadas corroboram a influência da reativação dessas estruturas por apresentarem fraturas com direções em dois trends principais, um NNW a NW e outro NNE a NE. Deste modo, os produtos hidrotermais identificados nas formações Teresina e Corumbataí podem fornecer informações sobre a atividade dessas zonas de falha. Eventos geológicos que afetaram a estrutura térmica da bacia do Paraná em escala regional ou promoveram a formação ou reativação de falhas também teriam papel importante para a atividade do sistema hidrotermal registrado nas formações Teresina e Corumbataí. Dentre estes eventos, podem ser destacados o impacto de Araguainha, que atingiu a borda norte da bacia na passagem permo-triássica $(254,7 \pm 2,5 \mathrm{Ma}$, Tohver et al., 2012), o magmatismo Serra Geral durante o Eocretáceo $(134,7 \pm 1 \mathrm{Ma}$, Thiede \& Vasconcelos, 2010) e o magmatismo alcalino durante o Neocretáceo e Terciário. 


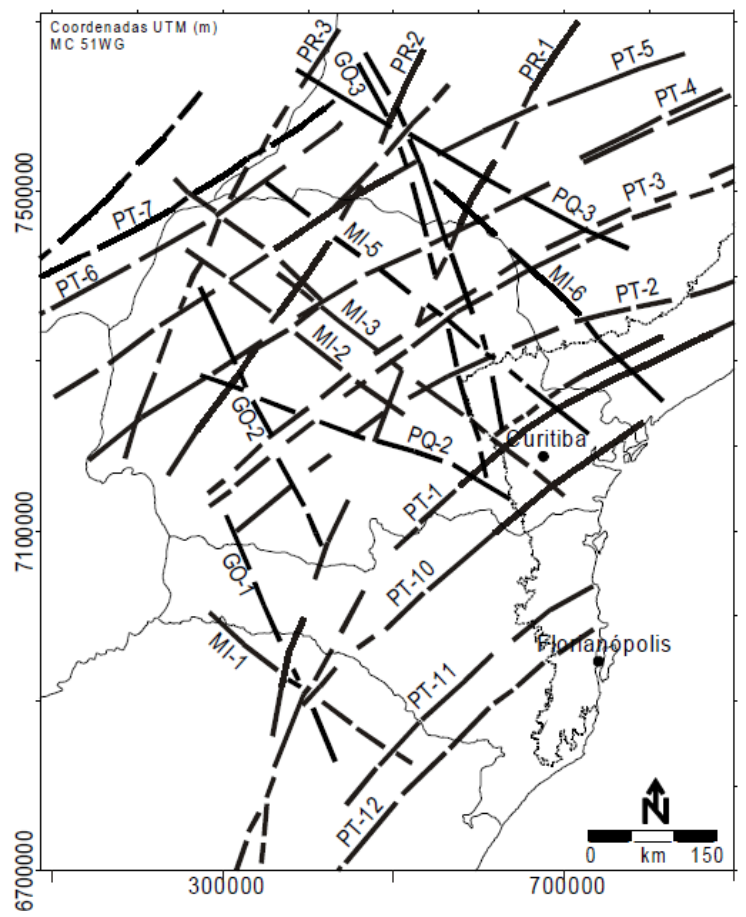

Figura 81. Mapa da ocorrência de lineamentos na Bacia do Paraná extraído de Artur \& Soares (2002). Destaque para os lineamentos da Jacutinga (PT-3) e Guapiara (MI-6).

Rostirolla et al. (2000) e Riccomini et al. (2005) discutem reativações de descontinuidades do embasamento durante o Neopermiano, as quais teriam sido responsáveis pela circulação de fluidos quentes enriquecidos em sílica, que permitiram a precipitação de calcedônia na substituição de calcários e como cimento precoce e da paragênese hidrotermal quarzto-dolomita-barita-calcita. A paragênese hidrotermal analcima-barita-celestita-calcita presente em calcário recristalizado também poderia estar associada a esta fase hidrotermal, apesar de não ser possível excluir a hipótese de associação entre esta paragênese e eventos hidrotermais posteriores ao Permiano. Stollhofen et al. (2000) sustentam que a Bacia do Paraná teria sido submetida a esforços distensivos durante o permo-triássico, o que teria levado à criação de um complexo sistema de riftes sobre a bacia sag. Segundo esses autores, esta bacia rifte estaria mais evidente do lado africano e citam a geometria do lago Gai-As na Namíbia para embasar esta hipótese. Stollhofen et al. (2000) demonstram que o eixo maior do Lago Gai-As teria direções NW a NNW, o que seria coincidente com a direção dos esforços vigentes no sudoeste do Gondwana durante o Permo-Triássico. Stollhofen et al. (2000) destacam a reativação tectônica de estruturas do embasamento durante o período de subsidência mecânica do rifte, tanto na margem falhada da Namíbia (Clemson et al., 1997) quanto ao longo do lado conjugado na América do Sul (Brito Neves et al., 1984). Contudo, as falhas permianas teriam se desenvolvido de forma mais difusa na porção da bacia na América do Sul. Diques clásticos nas formações 
Teresina e Corumbataí seriam produto de atividade sísmica permiana ligada à reativação da falha da Jacutinga (Turra, 2009). A reativação permiana da falha da Jacutinga poderia estar associada aos mesmos esforços intraplaca responsáveis pela geração do rifte Gai-As.

Rostirolla et al. (2000) descrevem que o alto estrutural de Quatinguá, entre Joaquim Távora e Curiúva (PR), próximo a Jacarezinho, é dominado por estruturas de direção NE e ocorre sobre a zona de falha da Jacutinga e próximo ao alinhamento de Guapiara. O alto de Quatinguá resultaria da combinação entre transcorrência sinistral de direção NE, resultante da deformação intraplaca associada à Orogenia La Ventana durante o Permo-Triássico, e distensão em falhas NW com transtensão dextral em falhas NE relacionadas à formação do Arco de Ponta Grossa durante o Eocretáceo (Rostirolla et al., 2000). Em ambos os eventos tectônicos teria havido a reativação da falha da Jacutinga e estruturas associadas, sendo que a maior parte das falhas NE teria sido gerada durante o permo-triássico (Rostirolla et al. 2000).

Soares et al. (1996) também relatam a ocorrência de hidrotermalismo ao associar indícios de hidrocarbonetos a zona de isotermas mais elevadas geradas pelos eventos de reativação da falha da Jacutinga nas regiões de Anhembi (SP) e Quatinguá (PR). Hidrotermalismo associado à falha da Jacutinga facilitaria a percolação de fluidos aquosos e de fraturamento hidráulico, resultando na formação de células de convecção em níveis mais rasos. Isto reforça origem hidrotermal para os cones silicosos com núcleo formado por geodo de cristais de quartzo, que foram interpretados como produto da atividade de geisers permianos em Anhembi (Yamamoto et al., 2005).

Lana et al. (2008) descrevem a ocorrência de cratera de impacto de $40 \mathrm{~km}$ de diâmetro que afeta unidades permianas do Grupo Passa Dois na região de Araguainha (GO). Segundo Tohver et al. (2012), o impacto de Araguainha teria efeitos em escala regional nas bacias do Paraná e Karoo, gerando anomalia térmica episódica. Isto favoreceria a ativação de sistemas hidrotermais, seja como resultado direto do impacto ou como produto da reativação de falhas, com isto haveria circulação de fluidos quentes em zonas rasas das formações Teresina e Corumbataí. Tohver et al. (2012) atribuem a idade de $254,7 \pm 2,5$ Ma para o impacto, o que seria contemporâneo ou posterior à sedimentação da Formação Teresina. A ocorrência de hidrotermalismo associado a impactos de corpos extraterrestres foi descrita por alguns autores (Daubar \& Kring, 2001; Abramov \& Kring, 2004; Osinski et al., 2005). 
Assim, o sistema de riftes Gai-As, a propagação intraplaca dos esforços da orogenia La Ventana e o impacto de Araguainha provocariam importantes alterações térmicas e estruturais em ampla área da bacia durante o Permo-Triássico, as quais teriam proporcionado a circulação de fluidos hidrotermais pela reativação de falhas do embasamento ou pela criação de novas falhas profundas. Os fluidos responsáveis pela silicificação pervasiva de calcários, formação de cones silicosos e precipitação precoce de calcedônia, quartzo, dolomita, barita e calcita autigênicos nas fácies da Formação Teresina, teriam migrado principalmente por zonas permeáveis verticais de direção NE associadas à reativação da falha da Jacutinga. Embora de modo subordinado, os fluidos silicosos também podem ter migrado por estruturas de direção NW associadas ao rifte Gai-As (Stollhofen et al., 2000).

As paleotemperaturas superiores a $200^{\circ} \mathrm{C}$ resultantes de reequilíbrios térmicos representariam o evento de maior temperatura que afetou as formações Teresina e Corumbataí nas áreas de estudo. O caráter regional deste evento reforça a sua associação com o magmatismo Serra Geral (Eocretáceo). Neste caso, as paleotemperaturas alcançadas durante o último evento térmico ocorrido na bacia, representado pelo magmatismo alcalino durante o Neocretáceo e Terciário, seriam inferiores às paleotemperaturas registradas durante o magmatismo Serra Geral.

O magmatismo Serra Geral seria produto de esforços de distensão durante a abertura do Oceano Atlântico. Nas áreas de estudo, isto levou à geração ou reativação de estruturas de direção NW e NE (subordinadas), as quais serviram de caminho para ascensão de lavas e percolação de fluidos aquosos quentes. Rostirolla et al. (2000) relatam que estes esforços promoveram deslocamentos verticais da ordem de metros a dezenas de metros, associados a movimentos sinistrais nas falhas de direção NW e à reativação dextral das falhas de direção NE. Nas regiões estudadas, o alinhamento de Guapiara se destaca como a principal estrutura de direção NW, reativada no Eocretáceo e que se define pela colocação de diques associados ao magmatismo Serra Geral (Ferreira et al., 1981; Ferreira, 1982). Como esta estrutura afeta o embasamento da bacia, teria sido importante zona para circulação de fluidos profundos hidrotermais.

Alguns autores reconhecem a existência de processos hidrotermais relacionados ao magmatismo Serra Geral (Santos \& Bonhomme, 1993; De Ros, 1998; Sant'anna et al., 2006; Costa, 2006; Duarte et al., 2009; Hartmann, 2011). Baseados no estudo de minerais autigênicos, Sant'Anna et al. (2006) argumentam que toda a sucessão permiana da Bacia do Paraná foi afetada por um evento hidrotermal simultâneo ao magmatismo Serra Geral. Para estes autores, o grau de transformação 
da esmectita em ilita indicam paleotemperaturas entre 100 e $150^{\circ} \mathrm{C}$ para as unidades permianas da borda leste da Bacia do Paraná e idades obtidas pelo método K-Ar em ilita indicam que essas temperaturas ocorreram durante o Eocretáceo (Sant'Anna et al., 2006). Duarte et al. (2009) propuseram um sistema epigenético e hidrotermal com temperaturas entre 100 e $150^{\circ} \mathrm{C}$ para explicar a origem de cavidades gigantes com cristalização tardia de ametista e ágata nos basaltos da Formação Serra Geral no sul do Brasil e Uruguai. De Ros (1998) interpreta a circulação de fluidos quentes através de fraturas relacionadas ao magmatismo Serra Geral e ao soerguimento do Arco de Ponta Grossa. Esta hipótese é sustentada pela presença de ilita diagenética com idades similares ao do magmatismo Serra Geral nos arenitos devonianos da Formação Furnas. Inclusões fluidas em sobrecrescimentos de quartzo nos arenitos da Formação Furnas apresentaram temperaturas de homogeneização de até $156^{\circ} \mathrm{C} \mathrm{e}$ salinidade entre 16 e $28 \%$ em peso equivalente de $\mathrm{NaCl}$ (De Ros, 1998). De acordo com Santos \& Bonhomme (1993), idades K/Ar em ilita diagenética da Formação Furnas definiram dois eventos térmicos, sendo um de temperatura mais elevada entre 140 e $130 \mathrm{Ma}$ e outro de temperatura mais baixa entre 120 e $100 \mathrm{Ma}$. Os autores associaram o primeiro episódio à quebra da Plataforma Sul Americana-África e abertura do Oceano Atlântico Sul, coexistente com o magmatismo Serra Geral. O segundo evento térmico estaria relacionado ao magmatismo ocorrido nos estágios finais de quebra do continente, durante o Eocretáceo e Neocretáceo.

A presença de betume em fraturas NW da Formação Teresina em Taguaí sugere a migração de hidrocarbonetos seguida de alteração térmica durante o magmatismo Serra Geral, já que a direção dessas fraturas é compatível com os esforços de distensão responsáveis pela colocação dos diques NW do alinhamento de Guapiara. A associação com veios beef indica que o betume presente em poros e fraturas da Formação Teresina seria gerado pela alteração térmica de hidrocarbonetos líquidos liberados de compartimentos com sobrepressão. Os eventos térmicos que afetaram a Formação Teresina na região do alinhamento de Guapiara indicam paleotemperaturas maiores que $200^{\circ} \mathrm{C}$. Cristais de calcita em fratura vertical de dique básico (amostra JZ-16A, Fartura, SP) apresentam inclusões fluidas secundárias de baixa salinidade. Como essas inclusões apresentam valores elevados de $\mathrm{TH}$, isto indicaria que houve percolação de fluidos com baixa salinidade durante o evento hidrotermal. Uma vez que este veio ocorre em fratura de direção NE e fraturas com esta direção são frequentes nos diques associados ao Serra Geral de direção NW estudados, isto indica que fraturas NE a NNE representam um evento de deformação posterior ao principal episódio de colocação de diques, embora fraturas com direções 
próximas a NW a NNW e NE a NNE possam ser produto do campo de esforço atuante durante o Eocretáceo (Renne et al., 1996; Rostirolla et al. 2000). Veios subverticais de calcita e quartzo de direção NNW, que ocorrem respectivamente nas formações Teresina (Jacarezinho, PR) e Corumbataí (Ipeúna,SP), podem estar associados aos esforços distensivos atuantes no Eocretáceo.

A observação de fluidos de diferentes salinidades nas formações Teresina e Corumbataí indica a falta de comunicação hidráulica entre as áreas estudadas, já que a migração seria principalmente vertical e ocorreria em compartimentos separados entre si por falhas ou zonas de fraturas verticais geradas ou reativadas durante os eventos tectônicos ocorridos no Permo-Triássico e Cretáceo, como já citado anteriormente. A migração vertical também é favorecida pelo fato das fácies arenosas ou carbonáticas apresentarem-se descontínuas, o que dificultaria a conexão horizontal. Assim, as descontinuidades associadas à reativação eocretácea e permiana das falhas da Jacutinga (NE) e de Guapiara (NW) seriam rotas preferenciais para a migração de fluidos diagenéticos e hidrotermais nas áreas de estudo. A sobrepressão observada nas rochas dos veios beef seria resultante da dificuldade em expulsar o fluido de poro devido à baixa permeabilidade das fácies durante a compactação e geração de hidrocarbonetos. Isto teria levado ao fraturamento hidráulico e a migração de fluidos aquosos de alta salinidade e hidrocarbonetos presentes ou gerados em poros de fácies de granulação fina para camadas adjacentes mais permeáveis. Em geral, os fluidos mais salinos teriam provável origem em águas quentes hidrotermais profundas, possivelmente enriquecidas em sulfatos pelo elevado tempo de interação com as rochas hospedeiras e pela dissolução local de evaporitos, enquanto que os fluidos de baixa salinidade seriam mais superficiais (meteórico) e alcançariam a Formação Teresina durante o Cretáceo através de fraturas verticais geradas pelo eventos de reativação das falhas de Jacutinga e Guapiara. A Figura 82 apresenta proposta do modelo de circulação dos fluidos na Formação Teresina durante o Eocretáceo. 


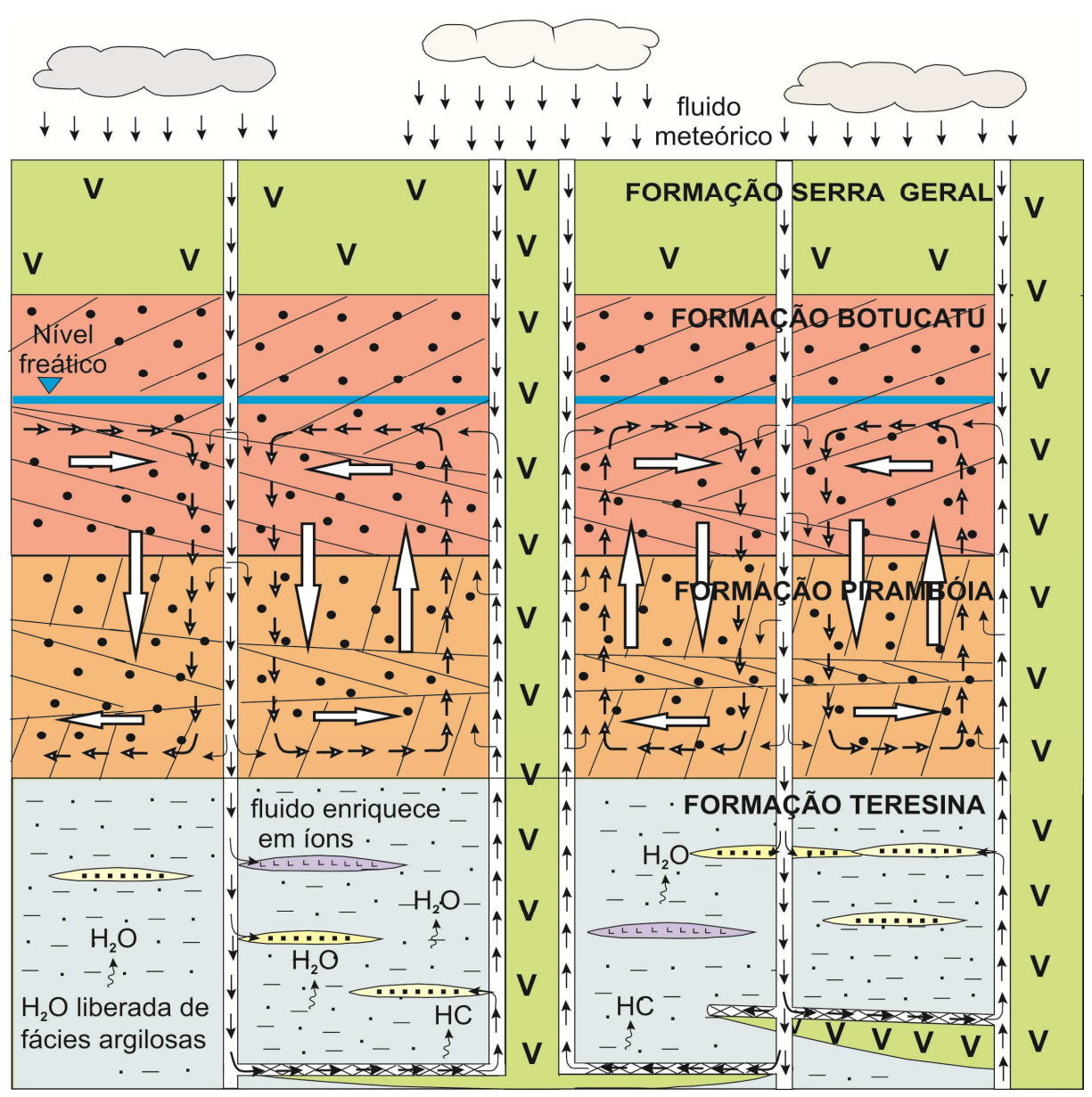

Figura 82. Modelo de circulação dos fluidos na Formação Teresina durante o Eocretáceo.

\subsection{Considerações sobre a geração e migração de hidrocarbonetos na Bacia do Paraná}

Nas áreas de estudo, o aquecimento devido ao soterramento das unidades permianas não seria suficiente para alcançar as temperaturas necessárias para gerar hidrocarbonetos líquidos leves com fase gasosa associada como observado nos veios de calcita e quartzo da Formação Teresina e Formação Corumbataí, respectivamente. Da mesma forma, paleotemperaturas maiores que $200^{\circ} \mathrm{C}$ para percolação de fluidos aquo-salinos também não seriam possíveis de ser alcançadas somente por soterramento na borda da bacia. Como resultado, a história térmica registrada pelos fluidos e minerais autigênicos das formações Teresina e Corumbataí seria pontuada por eventos geológicos capazes de gerar anomalias térmicas na borda leste da Bacia do Paraná. Esses eventos seriam fundamentais para a evolução dos sistemas petrolíferos da bacia, principalmente no que diz respeito à geração e migração de hidrocarbonetos. Dentre esses eventos geológicos, destaca-se a reativação de falhas do embasamento da bacia e o impacto de Araguainha durante o Permo-Triássico, o 
magmatismo basáltico Serra Geral e a reativação e/ou geração de falhas associadas durante o Eocretáceo e as intrusões de magma alcalino entre o Eocretáceo e o Neocretáceo. Estes eventos provocariam alterações na estrutura térmica da bacia e teriam ditado a geração e migração de hidrocarbonetos na bacia, se sobrepondo ao efeito térmico do soterramento.

As condições para a geração de hidrocarbonetos nas quatro principais regiões de estudo (Jacarezinho-Joaquim Távora, Taguaí-Fartura, Anhembi e Ipeúna) podem ser sugeridas considerando-se que as paleotemperaturas estimadas a partir das $\mathrm{TH}$ sejam representativas dos picos térmicos alcançados por nessas regiões. Assim, é possível posicionar cada região estudada em relação à janela de geração de hidrocarbonetos por meio das paleotemperaturas estimadas por temperaturas de homogeneização de inclusões fluidas (Tabela 4).

Tabela 4 - Geração de hidrocarbonetos nas regiões estudadas determinada pelas paleotemperaturas estimadas a partir de temperaturas de homogeneização (TH) de inclusões fluidas. As TH são consideradas estimativas mínimas do pico térmico. Temperaturas de geração de hidrocarbonetos obtidas a partir de Hunt (1995).

\begin{tabular}{|c|c|c|c|}
\hline Região & $\begin{array}{c}\text { Paleotemperatura } \\
\left({ }^{\circ} \mathbf{C}\right)\end{array}$ & $\begin{array}{c}\text { Janela de geração } \\
\text { de } \\
\text { hidrocarbonetos }\end{array}$ & $\begin{array}{c}\text { Indícios de } \\
\text { hidrocarbonetos }\end{array}$ \\
\hline Jacarezinho (PR) & 270 & Gás & Gás \\
\hline Taguaí-Fartura (SP) & 270 & Gás & $\begin{array}{c}\text { Óleo leve (45-50 } \\
\text { API) com gás } \\
\text { associado }\end{array}$ \\
\hline Anhembi (SP) & 150 & Gás & ----- \\
\hline Ipeúna (SP) & 190 & Gás & Óleo leve a médio \\
\hline
\end{tabular}

Desta forma, os maiores valores significativos de $\mathrm{TH}$ observados em Jacarezinho foram registrados por inclusões fluidas presentes em cristais de calcita blocosa de preenchimento de cavidades de dissolução da fácies chert nodular brechado. Em todas essas amostras a moda das $\mathrm{TH}$ apresentaram valores maiores ou iguais a $200^{\circ} \mathrm{C}$ com vários registros de temperaturas maiores que $300^{\circ} \mathrm{C}$, sendo que a moda registrou valores entre 260 e $280^{\circ} \mathrm{C}$. O mesmo aconteceu em Taguaí, cujas maiores TH foram observadas em inclusões fluidas presentes em calcita blocosa de preenchimento de cavidades de dissolução em fácies packstone/grainstone oolítico brechado, que registraram moda com os mesmos valores observados em Jacarezinho, 
entre 260 e $280^{\circ} \mathrm{C}$. Isto indica que o pico térmico observado para essas regiões de Jacarezinho e Taguaí e seus arredores (Joaquim Távora, Santo Antonio da Platina e Fartura) teria maior potencial para janela de geração de gás. Em Anhembi, os maiores valores com quantidade significativa de $\mathrm{TH}$ em inclusões fluidas em cristais de quartzo de geodo estão compreendidos entre 140 e $160^{\circ} \mathrm{C}$. Em Ipeúna, as inclusões fluidas em cristais de quartzo de veio registraram $\mathrm{TH}$ com moda entre 180 e $200^{\circ} \mathrm{C}$. Em ambas as regiões de Ipeúna e Anhembi, as TH também apontariam para janela de geração de gás. A preservação de hidrocarbonetos líquidos como é observado em regiões onde o pico térmico apontaria para janela de geração de gás é explicada pelo curto intervalo de duração do aquecimento pelo magmatismo Serra Geral como será discutido posteriormente.

A análise dos maiores valores significativos das $\mathrm{TH}$ observados nas regiões permitiu concluir que Jacarezinho e Taguaí teriam sofrido ação térmica mais intensa em comparação às outras regiões. Isto está em acordo com o fato de estarem localizadas sobre o flanco norte do Arco de Ponta Grossa. Esta área se destaca pelo alinhamento de Guapiara, caracterizado por enxame de diques, e pela espessura relativamente reduzida das unidades que separam a Formação Teresina da capa de rochas magmáticas da Formação Serra Geral. Isto propiciaria maior influência térmica das rochas magmáticas sobre a Formação Teresina. As regiões de Ipeúna e Anhembi estão distantes de zonas com elevada concentração de corpos ígneos intrusivos e apresentam maior espessura das unidades situadas entre as formações Teresina e Serra Geral. Assim, o menor efeito térmico do magmatismo Serra Geral nesta região é corroborado pelas TH modais mais baixas observadas principalmente em Anhembi. Por outro lado, em Ipeúna foram registrados alguns valores de $\mathrm{TH}$ muito mais elevados que os observados pela TH modal. Se estes valores de menor representatividade estatística não corresponderem a erros devido à aquisição de medidas, então não estariam, a princípio, de acordo com a suposição de que esta área sofreria o menor efeito térmico por estar mais distante do Arco de Ponta de Grossa. Contudo, o registro de TH mais elevadas seriam explicadas pelo fato dessas medidas representarem influência térmica local da ocorrência de sils e diques adjacentes à Formação Corumbataí.

Neste estudo, os hidrocarbonetos observados nas formações Teresina e Corumbataí indicaram maturação e migração de hidrocarbonetos ligada ao magmatismo Serra Geral. Os hidrocarbonetos leves que ocorrem como inclusões secundárias em veios subverticais de quartzo da Formação Corumbataí teriam como provável rocha geradora os folhelhos negros da Formação Irati (Membro Assistência), 
já que estas rochas estão distribuídas por toda a bacia e correspondem a principal rocha geradora dos hidrocarbonetos líquidos e betume observados na borda leste da Bacia do Paraná. Por outro lado, a ocorrência de hidrocarbonetos leves em intervalo estratigráfico restrito da Formação Teresina em Taguaí sugere rocha geradora de origem mais local. Estes hidrocarbonetos ocorrem como inclusões em veios beef e sua fluorescência em azul indica tratar-se de óleo leve (45-50 API) Condições de sobrepressão indicadas pela ocorrência dos veios beef teriam um importante papel para migração dos fluidos dentro da Formação Teresina. A falta de camadas permeáveis contínuas associada à condições de sobrepressão dificulta a migração de hidrocarbonetos a partir de camadas subjacentes dos folhelhos da Formação Irati. Neste caso, camadas delgadas de wackestones e mudstones ricos em matéria orgânica da porção superior da Formação Teresina seriam as rochas geradoras dos hidrocarbonetos.

Em bacias sedimentares afetadas por magmatismo, intrusões promovem a dissolução de minerais e a geração de salmouras hidrotermais, que são transportadas para zonas distantes mais frias (Polyansky et al., 2003). Fluidos aquosos de alta salinidade e hidrocarbonetos leves aprisionados nos veios beef da Formação Teresina implicam migração combinada de hidrocarbonetos e salmouras hidrotermais. Fluidos hidrotermais podem melhorar a transferência de calor em bacias sedimentares afetadas por magmatismo. $\mathrm{O}$ aquecimento devido ao magmatismo pode favorecer a geração de hidrocarbonetos bem como promover a transformação de óleo, anteriormente gerado pelo soterramento de rochas geradoras, em gás.

Derrames e intrusões associados ao magmatismo Serra Geral na região de Fartura alcançaram temperaturas aproximadas de $1000^{\circ} \mathrm{C}$ (Janasi et al. 2007). Hurter \& Pollack (1994) propuseram um modelo para explicar o efeito térmico de derrames e sils basálticos associados ao magmatismo Serra Geral nas rochas sedimentares adjacentes. Este modelo permite calcular temperaturas das rochas sedimentares em função do tempo desde a colocação de corpos extrusivos e intrusivos e da distância das rochas magmáticas. $O$ incremento de temperatura causado pelos derrames ou sils diminui exponencialmente com o tempo, se tornando insignificante depois de períodos de centenas a milhares de anos. De acordo com o modelo de Hurter \& Pollack (1994), rochas sedimentares depositadas aproximadamente a $1 \mathrm{~km}$ abaixo da capa de derrames basálticos com $900 \mathrm{~m}$ de espessura alcançam temperatura máxima de aproximadamente $200^{\circ} \mathrm{C}$ após 15.000 anos (temperatura superficial de $20^{\circ} \mathrm{C}$ e gradiente geotérmico de $26^{\circ} \mathrm{C} / \mathrm{km}$ ). O efeito térmico de sils e diques é caracterizado por picos de altas temperaturas dentro da zona intrudida. A temperatura máxima 
alcançada pelas rochas sedimentares localizadas aproximadamente a $100 \mathrm{~m}$ de sucessão formada por 10 sils com 1 a 12 m de espessura é cerca de $75^{\circ} \mathrm{C}$ (Hurter \& Pollack, 1994). Esta temperatura é alcançada por volta de 100 anos após as intrusões. $\mathrm{O}$ aquecimento devido às intrusões envolve intervalo de tempo de centenas de anos enquanto que o efeito da capa de basalto é significante para centenas a milhares de anos. Nas regiões de estudo, as formações Teresina e Corumbataí estão circundadas por capa de rocha vulcânica da Formação Serra Geral e diques e sils associados. Gimenez (1999) descreve a ocorrência de um dique com 500 m de espessura e $15 \mathrm{~km}$ de comprimento na região entre Fartura e Taguaí. Para alguns autores, o efeito térmico de sils e diques sobre unidade permianas da Bacia do Paraná seria maior que o efeito da capa de basalto (Araújo et al., 2000). Contudo, as elevadas paleotemperaturas registradas nas rochas das formações Teresina e Corumbataí não poderiam ser explicadas exclusivamente pela ocorrência de diques e sils, cuja concentração e volume são variáveis entre as áreas estudadas. O caráter regional dessas paleotemperaturas elevadas seria mais compatível com o efeito térmico da capa de derrames. Isto estaria de acordo com o modelo numérico de Hurter \& Pollack (1994), o qual prevê que o efeito térmico da capa de derrames sobre as rochas encaixantes seria mais significativo. Neste caso, a espessura da capa de derrames e a sua distância em relação às rochas geradoras seriam os principais controles sobre a maturação da matéria orgânica e geração de hidrocarbonetos. O volume de sils e diques associados ao magmatismo Serra Geral é significativamente menor que o volume da capa de derrames, de modo que provocariam efeito mais local, restrito às rochas encaixantes adjacentes.

De acordo com Kontorovich et al. (1997), o principal efeito do magmatismo básico neopermiano a mesotriássico sobre os sistemas petrolíferos da Bacia de Tunguska foi a conversão de hidrocarbonetos líquidos em gasosos. O modelo físico de propagação de calor e geotermômetros baseados em pares de minerais gerados por metamorfismo de contato (muscovita-biotita, muscovita-clorita, muscovita-plagioclásio e calcita-dolomita) indicam que as rochas sedimentares próximas a sils e diques ( $>20$ $\mathrm{m}$ de espessura) da Bacia de Tunguska alcançariam temperaturas de 100 a $700^{\circ} \mathrm{C}$, com esta temperatura dependendo da distância e espessura das rochas ígneas (Kontorovich et al., 1997). Para Kontorovich et al. (1997), o aquecimento devido ao magmatismo provoca a rápida retirada de hidrogênio da matéria orgânica em comparação com o aquecimento mais lento devido ao soterramento. Esses autores definem três zonas de alteração térmica da matéria orgânica em função da distância da rocha intrusiva: I) zona de destruição de hidrocarbonetos e grafitização da matéria 
orgânica (distância de 0 a 0,25 da espessura da intrusão); II) zona de geração de gás seco (0,25 a 0,50 da espessura da intrusão); III) zona de geração de hidrocarbonetos líquidos (0,50 a 1,25 da espessura da intrusão).

A espessura preservada da capa de rocha vulcânica na borda leste da Bacia do Paraná é de aproximadamente 400 m (Zalán et al., 1991; Janasi et al., 2007) No centro-leste de São Paulo, as formações Teresina e Corumbataí estão cerca de $300 \mathrm{~m}$ abaixo dos derrames do magmatismo Serra Geral. Já no centro-sul de São Paulo e norte do Paraná, a Formação Teresina encontra-se cerca de 150 a 200 m abaixo dos derrames. Isto se deve à menor espessura das unidades intermediárias entre as formações Teresina e Serra Geral no flanco norte do Arco de Ponta Grossa. Assim, as regiões estudadas podem ser divididas em duas áreas, de acordo com a distância entre as formações Teresina e Corumbataí e a capa de derrames: 1) setor SW no flanco norte do Arco de Ponta Grosa (Jacarezinho, Santo Antonio da Platina, Joaquim Távora, Fartura e Taguaí); 2) setor NE, distante do Arco de Ponta Grossa (Anhembi e Ipeúna). O modelo de Kontorovich et al. (1997) que analisa o efeito térmico das rochas magmáticas sobre rochas sedimentares adjacentes, segundo a distância e espessura dos corpos ígneos permite avaliar o efeito térmico da capa de basalto da Formação Serra Geral sobre as rochas das formações Teresina e Corumbataí. Desta forma, o setor SW da área estudada (1) estaria na transição entre a zona de geração de gás seco e hidrocarboneto líquido enquanto que o setor NE (2) estaria no mínimo na zona de geração de hidrocarboneto líquido, considerando distâncias maiores que a metade da espessura da capa de basalto. Entretanto, condições para geração de gás também seriam alcançadas, considerando que paleotemperaturas maiores que $200^{\circ} \mathrm{C}$ também foram observadas no setor NE. Uma vez que o registro dessas paleotemperaturas maiores que $200^{\circ} \mathrm{C}$ foram associadas à ocorrência local de corpos intrusivos nesta região, a área de geração de gás estaria limitada nas proximidades da colocação desses corpos intrusivos. Stewart et al. (1996) interpretam que a duração máxima do magmatismo Serra Geral seria de 10 a 12 Ma. No entanto, idades Ar-Ar combinadas com dados paleomagnéticos indicam duração menor que 2 Ma (Renne et al., 1996). O caráter episódico do magmatismo Serra Geral teria sido confirmado pela datação $\mathrm{Ar}-\mathrm{Ar}$ de amostras previamente datadas que apresentaram as idades mais antiga e mais jovem já registradas para o magmatismo (Thiede \& Vasconcelos, 2010). Segundo este estudo, a duração do magmatismo Serra Geral seria menor que 1,2 Ma. Desta forma, o curto intervalo de tempo do episódio de aquecimento associado ao magmatismo Serra Geral favoreceria a preservação de hidrocarbonetos líquidos, apesar das paleotemperaturas poderem indicar condições para geração de gás. 
Os caminhos de migração para os hidrocarbonetos, assim como discutido para os fluidos aquosos hidrotermais, também estariam associados à estruturas reativadas principalmente em eventos tectônicos ocorridos no Permo-Triássico e Eocretáceo. Neste contexto, a falha da Jacutinga e o alinhamento de Guapiara se destacam nas áreas de estudo como os principais caminhos para a migração de hidrocarbonetos em escala regional. Porém, a criação de descontinuidades para a migração de fluidos desde o Permiano, ao mesmo tempo que foram importantes caminhos de migração de hidrocarbonetos, também podem ter sido prejudiciais para a preservação de acumulações de hidrocarbonetos. Isto se deve ao fato de que essas descontinuidades também teriam permitido a entrada de água meteórica em zonas profundas a pelo menos centenas de metros abaixo da superfície, o que levaria à biodegradação e oxidação dos hidrocarbonetos. A possível degradação precoce dos hidrocarbonetos gerados durante o Eocretáceo deve ser considerada nos modelos para prospecção de hidrocarbonetos em áreas próximas às falhas que tenham se estendido até ou próximo à superfície. Processos de cimentação precoce podem gerar zonas mais favoráveis à preservação de hidrocarbonetos. Para isto, é fundamental o entendimento dos processos responsáveis pela gênese dos minerais autigênicos associados à zonas de falha da Bacia do Paraná.

\section{CONCLUSÕES}

- A intensa silicificação dos calcários da Formação Teresina teria ocorrido durante a eodiagênese e estaria associada à ocorrência de eventos hidrotermais. Esses eventos hidrotermais podem estar associados à atividade de falhas ligadas ao sistema de riftes Gai-As, à propagação intraplaca dos esforços da Orogenia La Ventana e ao impacto de Araguainha. Estes fatores provocariam importantes alterações térmicas em ampla área da bacia durante o Permo-Triássico;

- A paragênese mineral precoce formada por calcedônia, quartzo euédrico, barita, dolomita e calcita blocosa em cavidade de dissolução em chert nodular brechado e a paragênese calcita espática, barita, celestita e analcima cúbica (de alta temperatura) em calcário recristalizado também seriam produto de eventos hidrotermais durante o Permo-Triássico;

- A extensa variação das temperaturas de homogeneização obtidas em quase todas as amostras estudadas sugere reequilíbrios das inclusões devido a aquecimento posterior ao aprisionamento do fluido. Portanto, as $\mathrm{TH}$ representariam paleotemperaturas de eventos térmicos posteriores ao aprisionamento dos fluidos; 
- Os valores mais elevados das TH de reequilíbrio térmico corresponderiam à estimativa da temperatura mínima do pico térmico a que os minerais autigênicos e rochas hospedeiras das inclusões fluidas foram submetidos.

- Temperaturas de homogeneização de inclusões fluidas reequilibradas em calcita e quartzo autigênicos indicam que as formações Teresina e Corumbataí alcançaram temperaturas de no mínimo $200^{\circ} \mathrm{C}$ na borda da bacia;

- O aquecimento pelo soterramento das unidades permianas não teria sido suficiente para alcançar temperaturas maiores que $200^{\circ} \mathrm{C}$ e gerar hidrocarbonetos líquidos leves em veios horizontais de calcita da Formação Teresina e em veios de quartzo da Formação Corumbataí;

- Uma vez que as TH são de reequilíbrio, registrariam o evento térmico de maior temperatura nas regiões de estudo. Este evento seria produto do magmatismo Serra Geral durante o Eocretáceo;

- A acorrência de inclusões de óleo leve nas formações Teresina e Corumbataí (API $45-50^{\circ}$ ) é compatível com as paleotemperaturas estimadas para estas unidades nas áreas estudadas;

- As formações Teresina e Corumbataí registram paleofluidos aquosos de baixa a alta salinidade. Inclusões fluidas de alta salinidade podem indicar fluidos originados em zonas profundas ou pela dissolução de níveis evaporíticos. Inclusões fluidas de baixa salinidade indicariam fluidos de origem meteórica.

- Paleofluidos aquosos com diferentes salinidades nas formações Teresina e Corumbataí indicam a falta de comunicação hidráulica entre as áreas estudadas. A circulação de fluidos seria principalmente vertical e ocorreria em compartimentos separados por falhas e zonas de fraturas verticais geradas ou reativadas durante os eventos tectônicos do Permo-Triássico e Cretáceo;

- Os veios beef estariam associados à compartimentos de sobrepressão na Formação Teresina. Isto permitiria a saída de fluidos aquosos de alta salinidade aprisionados em poros de fácies pelíticas, possivelmente combinada com a geração e expulsão de hidrocarbonetos durante o magmatismo Serra Geral;

- As fraturas verticais de direção NW a NNW e NE a NNE seriam os principais caminhos de migração das águas de poro soterrada e de hidrocarbonetos, além de ser rota para entrada de água meteórica;

- Essas fraturas estariam associadas principalmente à descontinuidades do embasamento reativadas durante o Permo-Triássico e Eocretáceo, onde as falhas da Jacutinga (NE) e de Guapiara (NNW-NW) representariam as maiores e principais estruturas da área estudada; 
- O betume sólido que preenche fraturas de direção NW corresponderia a hidrocarbonetos líquidos termicamente alterados (pirobetume);

- A espessura reduzida das unidades de rochas sedimentares triássicas a eocretáceas no flanco norte do Arco de Ponta Grossa, especialmente nas regiões de Jacarezinho-Joaquim Távora (PR) e Taguaí-Fartura (SP) favoreceriam o efeito térmico da capa de basalto sobre as unidades permianas, cujo aquecimento a temperaturas maiores que $200^{\circ} \mathrm{C}$ permitiriam a geração de hidrocarbonetos leves. 


\section{REFERÊNCIAS BIBLIOGRÁFICAS}

Abramov O. \& Kring D.A. 2004. Numerical modeling of an impact-induced hydrothermal system at the Sudbury crater. Journal of Geophysical Research, 109, E10, E10007, 1-16., doi: 10.1029/2003JE002213.

Almeida F.F.M. \& Melo M.S. 1981. A Bacia do Paraná e o vulcanismo Mesozóico. In: IPT, Mapa Geológico do Estado de São Paulo, escala 1:500000, São Paulo, monografia $n^{\circ} 06,1: 46-81$.

Araújo L.M., Trigüis J.A., Cerqueira J.R., Freitas L. C. da S. 2000. The atypical Permian petroleum system of the Paraná Basin, Brazil. In: Mello M.R. \& Katz B.J. (Eds.). Petroleum systems of South Atlantic margins. AAPG Memoir, 73, 377402.

Araújo C.C. 2003. Gênese das ocorrências de arenito asfáltico da borda leste da Bacia do Paraná, SP. Tese de Doutoramento, Instituto de Geociências, Universidade de São Paulo, São Paulo, 135 p.

Artur P.C. \& P.C. Soares 2002. Paleoestruturas e petróleo na Bacia do Paraná, Brasil. Revista Brasileira de Geociências, 32(4), 433-448.

Bakker R.J., 2003. Package FLUIDS 1. Computer programs for analysis of fluid inclusion data and for modeling bulk fluid properties. Chemical Geology, 194, 323.

Biondi, J. C. 2003. Sistema hidrotermal magmático. In: Biondi J.C. Processos metalogenéticos e os depósitos minerais brasileiros. São Paulo: Oficina de Textos, 99-218.

Brito Neves B. B., Fuck R. A., Cordani U.G., Thomas F. A. 1984. Influence of basement structures on the evolution of the major sedimentary basins of Brazil: a case of tectonic heritage. Journal of Geodynamics, 1, 495-510.

Burke E.A.J. 2001. Raman microspectrometry of fluid inclusions. Lithos, 55, 139-158.

Burrus R.C. 2003. Petroleum Fluid Inclusions, An Introduction. In: Samson I., Anderson

A., Marshall D. (Eds.). Fluid Inclusions: Analysis and Interpretation. Mineralogical Association of Canada, Short Course Series, 32, 159-174.

Cardott B.J. 1991. Organic petrology of epi-impsonite at Page, Oklahoma, U.S.A. Organic Geochemistry, 17(2), 185-191.

Chang H.K., MacKenzie F.T, Schoonmaker J. 1986. Comparision between the diagenesis of dioctahedral and triochedral smectite, Brazilian offshore basins. Clay. Clay Mineral., 34, 407-423.

Choquette P.W. \& Pray L.C. 1970. Geologic nomenclature and classification of porosity in sedimentary carbonates. Bull. Am. Ass. petrol. Geol., 54, 207-250. 
Clemson J., Cartwright J., Booth J. 1997. Structural segmentation and the influence of basement structure on the Namibian passive margin: Journal of the Geological Society (London), 154, 477-482.

Coelho C.E.S. 2004. O estudo de inclusões fluidas na exploração de petróleo. Boletim de Geociências da Petrobras, 13(1), 61-80.

Costa M.N.S. 2006. Diagênese e alteração hidrotermal em rochas sedimentares da Formação Corumbataí, Permiano Superior, Mina Granusso, Cordeirópolis/SP. Tese de Doutoramento, UNESP, Rio Claro, 140 p.

Crawford M.L. \& Hollister L.S. 1992. Fluid-rock interactions during Metamorphism. In: Walther J.V. Wood B.J. (Eds.). Advances in Physical Chemistry, 4, 1-35.

Daemon R.F. \& Quadros L.P. 1970. Bioestratigrafia do Neopaleozóico da Bacia do Paraná. Congresso Brasileiro de Geologia, 24, 359-412.

Daubar I. J. \& Kring D. A. 2001. Impact-induced hydrothermal systems: Heat sources and lifetimes. $32^{\circ}$ Lunar Planetary Science, Abstract 1727. CD-ROM.

Davis D.W., Lowenstein T.K., Spencer R.J. 1990. Melting behavior of fluid inclusions in laboratory-grown halite crystals in the systems $\mathrm{NaCl}-\mathrm{H} 20, \mathrm{NaCl}-\mathrm{KCl}-\mathrm{H} 2 \mathrm{O}, \mathrm{NaCl}-$ $\mathrm{MgCl} 2-\mathrm{H} 2 \mathrm{O}$ and NaCl-CaCl2-H2O. Geochimica et Cosmochimica Acta, 54, 591601.

De Ros L.F. 1998. Heterogeneous generation and evolution of diagenetic quartz arenites in the Silurian-Devonian Furnas Formation of the Paraná Basin, southern Brazil. Sedimentary Geology, 116, 99-128.

Duarte L. C., Hartmann L.A., Vasconcellos M.A.Z., Medeiros J.T.N., Theye T. 2009. Epigenetic formations of amethyst-bearing geodes from Los Catalanes geomological district, Artigas, Uruguay, southern Paraná Magmatic Province. Journal of Volcanology and Geothermal Research, 184, 427-436.

Dunham R.J. 1962. Classification of carbonate rocks according to their depositional texture. In: Ham W.E. (Ed.). Classification of Carbonate Rocks - a symposium: Tulsa, OK, American Association of Petroleum Geologists Memoir 1, 108-121.

Embry A.F. \& Klovan J.E. 1971. A Late Devonian reef tract on northeastern Banks Island, N.W.T. Bulletin of Canadian Petroleum Geology, 19, 730-781.

Faria R.S, Ricardi-Branco F., Giannini P.C.F, Sawakuchi A.O., Del Bem L.E.V. 2009. Lycopodiopsis derbyi Renault from the Corumbataí Formation in the state of São Paulo (Guadalupian of Paraná Basin, Southern Brazil): New data from compressed silicified stems. Review of Palaeobotany and Palynology, 158, 180192. 
Ferreira F.J.F., Moraes R.A.V., Ferrari M.P., Vianna R.B. 1981. Contribuição ao estudo do alinhamento estrutural de Guapiara. In: Simpósio Regional de Geologia, 3, Curitiba, Atas, Curitiba, SBG, Núcleo de São Paulo, 1, 226-240.

Ferreira F.J.F. 1982. Integração de dados aeromagnéticos e geológicos: configuração e evolução tectônica do Arco de Ponta Grossa. Dissertação de Mestrado, Instituto de Geociências, Universidade de São Paulo, São Paulo, 170 p.

Ferrill D.A., Morris A.P., Evans M.A., Burkhard M., Groshong R.H., Onasc, C.M. 2004. Calcite twin morphology: a low-temperature deformation geothermometer. Journal of Structural Geology, 26, 1521-1529.

Folk R.L. 1959. Practical classification of limestones - American Association of Petroleum Geologists Bulletin, 43, 1-38.

Folk, R.L. 1962. Spectral subdivision of limestone types. In: Ham W.E. (Ed.). Classification of Carbonate Rocks - a symposium: Tulsa, OK, American Association of Petroleum Geologists Memoir 1, 62-84.

França A.B., Araújo L.M., Maynard J.B., Potter P.E. 2003. Secondary porosity formed by deep meteoric leaching: Botucatu eolianite, southern South America. AAPG Bulletin 87, 1073-1082.

Franzinelli E. 1972. Arenitos asfálticos do estado de São Paulo. Tese de Doutoramento, Instituto de Geociências, Universidade de São Paulo, 104 p.

Flügel E. 2004. Microfacies of Carbonate Rocks. Springer, 976 p.

Fúlfaro V.J. \& Suguio K. 1967. Campos de dique de diabásio da Bacia do Paraná. In: Boletim da Sociedade Brasileira de Geologia, São Paulo. 16(2), 23-38.

Fuzikawa K. 1985. Inclusões fluidas: Métodos usuais de estudo e aplicações. In: Contribuições à Geologia e à Petrologia. Boletim Especial, Núcleo de Minas Gerais, SBG, 29-44.

Gesicki A.L.D. 2007. Evolução diagenética das formações Pirambóia e Botucatu (Sistema Aquífero Guarani) no Estado de São Paulo. Tese de Doutoramento, Instituto de Geociências, Universidade de São Paulo, São Paulo, 175 p.

Ghilardi R.P. \& Simões M.G. 2002. Foram os bivalves do Grupo Passa Dois (exclusive Formação Rio do Rasto) moluscos dulcícolas? Pesquisas em Geociências, 29, 91-92.

Ghobarkar H. \& Schäf. 1999. Effect of temperature on hydrothermal synthesis of analcime and viséite. Materials Science and Engineering, 163-167.

Giannini P.C.F., Sawakuchi A.O., Fernandes L.A., Donatti L.M. 2004. Paleoventos e Paleocorrentes Subaquosas do Sistema Deposicional Pirambóia nos Estados de São Paulo e Paraná, Bacia do Paraná: estudo baseado em análise estatística de dados azimutais. Revista Brasileira de Geociências, 34(2), 282-292. 
Gimenez D.Z. 1999. Caracterização Tecto-estrutural do enxame de diques cretácicos na região de Fartura, Estado de São Paulo. Dissertação de Mestrado, UNESP, Rio Claro, $153 p$.

Goldstein R.H. 1988. Cement stratigraphy of Pensylvanian Holder Formation, Sacramento Mountains, New Mexico: American Association of Petroleum Geologistis Bulletin, 72, 425-438.

Goldstein R.H. 1993. Fluid inclusions as carbonate microfabrics: a petrographic method to determine diagenetic history. In: Rezak R. \& Lavoie D. L. (Eds.) Carbonate Microfabrics: Frontiers in Sedimentary Geology. Springer-Verlag, 279-290.

Goldstein R.H. \& Reynolds T.J. 1994. Systematics of fluid inclusions in diagenetic minerals. Society for Sedimentary Geology Short Course, 31, Tulsa, Society of Sedimentary Geology, 199 p.

Gordon Jr. M. 1947. Classificação das formações gondwânicas do Paraná, Santa Catarina e Rio Grande do Sul. DNPM/DGM, Notas Preliminares e Estudos, 38, $19 \mathrm{p}$.

Güven H. 1988. Smectites. In: Bailey S.W. (Ed.). Hydrous Phyllosilicates, Reviews in Mineralogy 19. Mineralogical Society of America, Washington, DC, 497-559.

Hachiro J. 1996. O Subgrupo Irati (Neopermiano) da Bacia do Paraná. Tese de Doutoramento, Instituto de Geociências, Universidade de São Paulo, São Paulo, $196 \mathrm{p}$.

Hartmann L.A. 2011. Cretaceous tectonics of overpressured vapor from the Guarani aquifer deforming and mineralizing the Serra Geral Group, Paraná volcanic province. $13^{\circ}$ Simpósio Nacional de Estudos Tectônicos-VII International Symposium on Tectonics, 428-432.

Holz M., França A.B., Souza P.A., Iannuzi R., Rohn R. 2010. A stratigraphic chart of the Late Carboniferous/Permian succession of the eastern border of the Paraná Basin, Brazil, South America. Journal of South American Earth Sciences, 29(2), 381-399.

Hower J., Eslinger E.V., Hower M.E., Perry E.A. 1976. Mechanism of burial and metamorphism of argillaceous sediment: 1. Mineralogical and chemical evidence. Geol. Soc. Am. Bull., 87, 725-737.

Hunt J. M. 1995. Petroleum Geochemistry and Geology. Second Edition. Editora Freeman.

Hurter S.J. \& Pollack H.N. 1994. Effect of the Cretaceous Serra Geral igneous event on the temperatures and heat flow of the Parana Basin, southern Brazil. Basin Research, 6(4), 239-244. 
IPT - Instituto de Pesquisa Tecnológico. 1981. Mapa Geológico do Estado de São Paulo - Escala 1:500.000.

Jacob H. 1989. Classification, structure, genesis 801 and practical importance of natural solid bitumen (migrabitumen). International Journal of Coal Geology, 11, 65-79.

Janasi V.A., Montanheiro T.J., Freitas V.A., Reis P.M., Negri F.A., Dantas F.A. 2007. Geology, petrography and geochemistry of the acid volcanism of the Paraná Magmatic Province in the Piraju-Ourinhos region, SE Brazil. Revista Brasileira de Geociências, 37(4), 745-759.

Kontorovich A.E., Khomenko A.V., Burshtein L.M., Likhanov I.I., Pavlov A.L., Staroseltsev V.S., Ten, A.A. 1997. Intense basic magmatism in the Tunguska petroleum basin, eastern Siberia, Russia. Petroleum Geoscience, 3, 359-369.

Lana C., Souza Filho C.R.S., Marangoni Y.R., Yokoyama E., Trindade R.I.F., Tohver E., Reimold W.U. 2008. Structural evolution of the $40 \mathrm{~km}$ wide Araguainha impact structure, central Brazil. Meteoritics \& Planetary Sciences, 43, 701-716.

Marshall W.L. \& Warakomski J.M. 1980. Amorphous silica solubilities II. Effect of aqueous salt solutions at 25 C. Geochim. Cosmochim. Acta 44, 915-924.

Marshall W.L. \& Chen C.T.A. 1982. Amorphous silica solubilities V. Predictions of solubility behavior in aqueous mixed eletrolyte solutions up to $300 \mathrm{C}$. Geochim. Cosmochim. Acta 46, 289-291.

Matos S.L.F., Yamamoto J.K., Riccomini C., Hachiro J., Tassinari C.C.G. 2001. Absolute dating of Permian ash-fall in the Rio Bonito Formation, Paraná Basin, Brazil. Gondwana Research, 4, 421-426.

McKinley J.M., Worden R.H., Ruffell, A.H. 2003. Smectite in sandstones: a review of the controls on occurrence and behaviour during diagenesis. In: Worden R.H. \& Morad S. (Eds.). Clay Mineral Cements in Sandstones, International Association of Sedimentologists, Special Publication, 34, Blackwell Publishing, Oxford, 109128.

McLimans R.K. 1987. The application of fluid inclusions to migration of oil and diagenesis in petroleum reservoirs. Applied Geochemistry, 2, 585-603.

Medeanic S., Costa C.S.B., Corrêa I.C.S. 2006. Os palinomorfos nas reconstruções paleoambientais: Azolla filiculoides Lam. nos sedimentos holocênicos da Planície Costeira do Rio Grande do Sul. Gravel, 4, 49-61.

Melezhik V.A., Filippov M.M., Romashkin A.E. 2004. A giant Palaeoproterozoic deposit of shungite in NW Russia: genesis and practical applications. Ore Geology Reviews, 24, 135-154. 
Mello e Souza S.H. 1985. Fácies sedimentares das formações Estrada Nova e Corumbataí no Estado de São Paulo. Dissertação de Mestrado, Instituto de Geociências, Universidade de São Paulo, 142 p.

Mendes J.C. 1967. The Passa Dois Group (The Brazilian portion of the Paraná Basin). In: Bigarella J.J., Becker G.D., Pinto I.D. (Eds.). Problems in Brazilian Gondwana Geology, Curititba, 119-166.

Mendes, J. C. 1984. Sobre os paleoambientes deposicionais do Grupo Passa Dois. Revista do Instituto Geológico, 5(1/2), 15-24.

Méndez J.D. 2012. Fácies carbonáticas da Formação Teresina. Dissertação de Mestrado, Instituto de Geociências, Universidade de São Paulo, São Paulo, 71 p.

Milani E.J., Rangel H.D., Bueno G. V., Stica J.M., Winter W.R., Caixeta J.M. 2007. Bacias sedimentares brasileiras: cartas estratigráficas. Boletim de Geociências da Petrobrás, Rio de Janeiro, 15(2), 265-287.

Millot G. 1970. Geology of Clays. Springer, New York. 429 p.

Morad S. (Ed.) 1998. Carbonate Cementation in Sandstones: Distribution Patterns and Geochemical Evolution. Special Publication Number 26 of the International Association of Sedimentologists. Blackwell Science, 511 p.

Moraes Rego L.F. 1930. A geologia do petróleo no Estado de São Paulo. Rio de Janeiro. Boletim Serviço Geológico e Mineralógico do Brasil, 46, 1-110.

Munz I.A. 2001. Petroleum inclusions in sedimentary basins: systematics, analytical methods and applications. Lithos, 55, 195-212.

Nomura S.F. 2009. Caracterização de ocorrência de hidrocarbonetos da Formação Teresina, Bacia do Paraná no Estado de São Paulo. Monografia de Trabalho de Formatura, Instituto de Geociências, Universidade de São Paulo, 46 p.

Nomura S.F., Sawakuchi A.O., Bello R.M.S., Fuzikawa K., Dantas M.S.S. 2010. Caracterização de ocorrência de hidrocarbonetos da Formação Teresina, Bacia do Paraná no Estado de São Paulo. In: SBG, Congresso Brasileiro de Geologia, 45, Belém, Anais.

Oka-Fiori C., Santos L.J.C., Canali N.E., Fiori A.P., Silveira C.T., Briski S.J., Felipe R.S. 2006. Atlas geomorfológico do Estado do Paraná - Escala 1:250.000, modelos reduzidos 1:500.00. Minerais do Paraná e Universidade Federal do Paraná. Curitiba, 63 p.; il.

Osinski G.R., Lee P., Parnell J., Baron M., Spray J.G. 2005. A case study of impactinduced hydrothermal activity: The Haughton impact structure, Devon Island, Canadian High Arctic: Meteoritics \& Planetary Sciences, 40, 1859-1877.

Parnell J. \& Carey P.F. 1995. Emplacement of bitumen (asphaltite) veins in the Neuquén Basin, Argentina. AAPG Bulletin, 79, 1798-1816. 
Parnell J., Baron M., Mann P., Carey P. 2000. Significance of fibrous mineral veins in hydrocarbon migration: fluid inclusion studies. Journal of Geochemical Exploration, 69-70, 623-627.

Parnell J., Baron M., Mann P., Carey P. 2003. Oil migration and bitumen formation in a hydrothermal system, Cuba. Journal of Geochemical Exploration, 78-79, 409415.

Paytan A., Mearon S., Cobb K., Kastner M. 2002. Origin of marine barite deposits: Sr and $S$ isotope characterisation. Geology, 747-750.

Petri S. \& Coimbra A.M. 1982. Estruturas Sedimentares das Formações Irati e Estrada Nova (Permiano) e sua contribuição para elucidação dos seus paleoambientes geradores. In: Congresso Latino Americano de Geologia, 5, Argentina, Atas, 2, 352-371.

Pirajano F. 2009. Hydrothermal Process and Mineral Systems. Geological Survey of Western Australia, Perth, WA, Australia. Springer, 1250 p.

Pirajano F. \& van Kranendonk M.J. 2005. Review of hydrothermal processes and systems on Earth and implications for Martian analogues. Australian Journal of Earth Sciences: An International Geoscience Journal of the Geological Society of Australia, 52 (3), 329-351.

Polyansky O.P., Reverdatto V.V., Khomenko A. V., Kuznetsova, E.N. 2003. Modeling of fluid flow and heat transfer induced by basaltic near-surface magmatism in the Lena-Tunguska petroleum basin (Eastern Sibéria, Russia). Journal of Geochmical Exploration, 78-79, 687-692.

Prezbindowski D.R, Larese R.E. 1987. Experimental streching of fluid inclusions in calcite - Implications for diagenetic studies. Geology, 15, 333-336.

Radke B.H. \& Mathis R.L. 1980. On the formation and occurrence of saddle dolomite. Sedimentary Petrolology, 50, 1149-1168.

Ramos A. N. \& Formoso M. M. L. 1975. Argilominerais das rochas sedimentares da Bacia do Paraná. Rio de Janeiro. Centro de Pesquisas e Desenvolvimento Leopoldo A. Miguez de Mello - CENPES, Petrobrás, 9, 1-47.

Renne P.R., Deckart K., Ernesto M., Féraud G., Piccirillo E.M. 1996. Age of the Ponta Grossa dike swarm (Brazil), and implications to Paran flood volcanism. Earth and Planetary Science Letters, 144, 199-211.

Riccomini C. 1997. Arcabouço Estrutural e aspectos do tectonismo gerador e deformador da Bacia Bauru no Estado de São Paulo. Revista Brasileira de Geociências, 27(2), 153-162.

Riccomini C., Almeida R.P., Turra B.B., Chamani M.A.C., Fairchild T.R., Hachiro J. 2005. Reativação de falha do embasamento causa sismicidade no 
permotriássico da Bacia do Paraná. 12 Simpósio Nacional de Estudos Tectônicos- IV International Symposium on Tectonics, Curitiba, Boletim de Resumos Expandidos, 18-20.

Rocha-Campos A.C., Basei M.A.S., Nutman A.P., Santos P.R. 2007. SHRIMP U-Pb zircon ages of the late Paleozoic sedimentary sequence, Paraná Basin, Brazil. In: Simpósio Sobre Cronoestratigrafia da Bacia do Paraná, 4, 2007. Boletim de Resumos. Sociedade Brasileira de Paleontologia, Armação de Búzios, p.33.

Rodrigues N., Cobbold P.R., Loseth H., Ruffeth G. 2009. Widespread bedding parallel veins of fibrous calcite (_beef') in a mature source rock (Vaca Muerta Fm, Neuquén Basin, Argentina): evidence for overpressure and horizontal compression. Journal of the Geological Society, 166, 695-709.

Roedder E. 1984. Fluid Inclusions. In: Ribbe P.H. (Ed.), Reviews in Mineralogy, Mineralogical Society of América, 12, $646 \mathrm{p}$.

Rohn R. 1994. Evolução ambiental da Bacia do Paraná durante o Neopermiano no leste de Santa Catarina e do Paraná. Tese de Doutoramento, 2v, Instituto de Geociências, Universidade de São Paulo, São Paulo.

Rohn R. 2001. A estratigrafia da Formação Teresina (Permiano, Bacia do Paraná) de acordo com furos de sondagem entre Anhembi (SP) e Ortigueira (PR). In: Melo J.H.G., Terra G.J.S. (Eds.). Correlação de Seqüências Paleozóicas SulAmericanas. Ciência-Técnica-Petróleo, Exploração de Petróleo, Seção, 20, 209218.

Rohn R. 2007. The Passa Dois Group (Paraná Basin, Permian): investigations in progress. In: Workshop - Problems in the Western Gondwana Geology, South America-Africa Correlations: Du Toit revisited. Gramado, 2007. Extended Abstracts, Porto Alegre, UFRGS, Petrobras, 1, 151-157.

Rostirolla S. P., Assine M. L., Fernandes L. A., Artur P. C. 2000. Reativação de paleolineamentos durante a evolução da Bacia do Paraná - o exemplo do Alto Estrutural de Quatiguá. Revista Brasileira de Geociências, 30(4), 639-648.

Sant'Anna L.G., Clauer N., Cordani U.G., Riccomini C., Velázquez V.F., Liewig N. 2006. Origin and migration timing of hydrothermal fluids in sedimentary rocks of the Paraná Basin, South America. Chemical Geology, 230, 1-21.

Santos R.P. \& Bonhomme M.G. 1993. Datação K/Ar de argilas associadas às mineralizações e aos processos diagenéticos, em relação com a história da abertura do Oceano Atlântico Sul. Revista Brasileira de Geociências, 23, 61-67.

Santos R.V., Souza P.A., Alvarenga C.J.S., Dantas E.L., Pimentel M.M., Oliveira C.G., Araújo L.M. 2006. Shrimp U-Pb zircon dating and palynology of bentonitic layers 
frm the Permian Irati Formation, Paraná Basin, Brazil. Gondwana Research, 9, 456-463.

Sanz-Montero M.E., Rodriguez-Aranda J.P., Del Cura M.A.G. 2008. Dolomite-silica stromatolites in Miocene lacustrine deposits from the Duero Basin, Spain: the role of organotemplates in the precipitation of dolomite. Sedimentology, 55, 729-750.

Schneider R.L, Muhlmann H., Tommasi E., Medeiros, R. A.; Daemon R. F. Nogueira A. A. 1974. Revisão Estratigráfica da Bacia do Paraná. In: SBG, Congresso Brasileiro de Geologia, 28, Porto Alegre, Anais, 1, 41-64.

Scholle P.A. \& Ulmer-Scholle D.S. 2003. A Color Guide to the Petrography of Carbonate Rocks: Grains, textures, porosity, diagenesis. AAPG Memoir, 77, 459 p.

Senko J.M., Campbell B.S., Henriksen J.R., Elshahed M.S., Dewers T.A., Krumholx L.R. 2004. Barite deposition resulting from phototrophic sulphide-oxidizing bacterial activity. Geochimica et Cosmochimica Acta, 68, 773-780.

Shepherd T.J., Rankin A.H., Alderton D.H. 1985. A Practical Guide to Fluid Inclusions Studies. Blackie and Son Ltd, New York, 239p.

Simões M.G., Rocha-Campos A.C., Anelli L.E. 1998. Paleoecology and evolution of Permian pelecypod assemblages (Paraná Basin) from Brazil. In: Johnston P.A., Haggart J.W. (Eds.), Bivalves - An Eon of Evolution- Paleobiological Studies Honoring Norman D. Newell. University of Calgary Press, Calgary, 443-452.

Soares P.C. 1991. Tectônica sin-sedimentar cíclica na Bacia do Paraná. Tese de Titular, UFPR, Curitiba, PR, $148 \mathrm{p}$.

Soares P. C., Rostirolla S. P., Ferreira F. J. F., Stevanato R. 1996. O alto estrutural Pitanga-Quatiguá-Jacutinga na Bacia do Paraná: uma estrutura litosférica. In: Congresso Brasileiro de Geologia, 39, Salvador, Anais... , 5, 411-414.

Sorby H.C. 1858. On the microscopic structure of crystals, indicating the origin of minerals and rocks. Geological Society of London Quarterly Journal, 14, 453-500.

Stewart K., Turner S., Kelley S., Hawkesworth C., Kirsten L., Mantovani M. 1996. 3-d, 40Ar-39 Ar geochronology in the Paraná continental flood basalt province. Earth and Planetary Science Letters, 143, 95-109.

Stollhofen H., Stanistreet I. G., Rohn R., Holzförster F. e Wanke A. 2000. The Gai-As lake system, northern Namibia and Brazil. In Gierlowski-Kordesch E. H. \& Kelts K. R. (Eds.). Lake Basins through Space and Time, Studies in Geology, American Association Petroleum Geologists, 46, 87-108.

Strugale M., Rostirolla S.P., Mancini F., Portela Filho C.V., Ferreira F.J.F., Freitas R.C. 2007. Structural framework and Mesozoic-Cenozoic evolution of Ponta Grossa 
Arch, Paraná Basin, southern Brazil. Journal of South American Earth Sciences, 24, 203-227.

Suguio K., Salati E., Barcelos J. H. 1974. Calcários oolíticos de Taguaí (SP) e seu possível significado paleoambiental na deposição da Formação Estrada Nova. Revista Brasileira de Geociências, 4(3): 142-166.

Thiede D.S. \& Vasconcelos P.M. 2010. Paraná flood basalts: Rapid extrusion hypothesis confirmed by new 40Ar/39Ar results. Geology, 38(8), 747-750.

Thomaz-Filho A. 1982. Ocorrência de Arenito Betuminoso em Anhembi (SP) Cubagem e Condicionamento Geológico. Anais XXXII, Congresso Brasileiro de Geologia, Salvador, BA, 5, 2344-2348.

Tobin C. R. \& Claxton B.L. 2000. Multidisciplinary thermal maturity studies using vitrinite reflectance and fluid inclusion microthermometry: A new calibration of old techniques. AAPG Bulletin, 84 (10), 1647-1665.

Tohver E., Lana C., Cawood P.A., Fletcher I.R., Jourdan F., Sherlock S., Rasmussen R., Trindade R.I.F., Yokoyama E., Souza Filho C.R., Marangoni Y. 2012. Geochronological constraints on the age of Permo-Triassic impact event: $\mathrm{U}-\mathrm{Pb}$ and $40 \mathrm{Ar} / 39 \mathrm{Ar}$ results for the $40 \mathrm{~km}$ Araguainha structure of central Brazil. Geochimica et Cosmochimica Acta, 86(1), 214-227.

Tucker M.E. \& Bathurst R.G.C. (Eds.) 1990. Carbonate diagenesis. International Association of Sedimentologists, Reprint Series, 1, 312 p..

Tucker M.E. \& Wright V.P. 1990. Carbonate Sedimentology. Oxford, Blackwell Science Ltd., 482 p.

Turra B.B. 2009. Diques clásticos da Formação Corumbataí, Bacia do Paraná, no contexto da tectônica permotriássica do Gondwana Ocidental. Dissertação de Mestrado, Instituto de Geociências, Universidade de São Paulo, 96 p.

Vasconcelos C., McKenzie J.A., Bernasconi S., Grujic D., Tien, A.J. 1995. Microbial mediation as a possible mechanism for natural dolomite formation at low tempera- tures. Nature, 377, 220-222.

Wilson N.S.F. 2000. Organic petrology, chemical 925 composition, and reflectance of pyrobitumen from the El Soldado Cu deposit, Chile. International Journal of Coal Geology, 43, 53-82.

Yamamoto J.K., Fairchild T.R., Boggiani P.C., Montanheiro T.J., Araújo C.C., Kiyohara, P.K., Matos S.L.F., Soares P.C. 2005. A record of Permian subaqueous vent activity in southeastern Brazil. Nature, 438, 205-207.

Zaine M.F. 1980. Uma barreira geográfica no Paleozóico Superior na região de Fartura, SP. Dissertação de Mestrado, Instituto de Geociências, Universidade de São Paulo, São Paulo, 89 p. 
Zalán P. V., Wolff S., Conceição J. C. J., Astolfi M. A. M.; Vieira I. S., Appi V. T., Zanotto, O. A. 1987. Tectônica e sedimentação da Bacia do Paraná. Curitiba PR. In: Simpósio Sul-Brasileiro de Geologia, 3, Atas , 1, 441-477.

Zalán P.V., Wolf S., Conceição J.C., Astolfí A.M., Vieira I.S., Appi V.T., Zanotto, O.A., Marques A. 1991. Tectonics and sedimentation of the Paraná Basin. In: Ulbrich, H.H.G.J. \& Rocha-Campos, A.C. (Eds.). Gondwana Seven. Instituto de Geociências, Universidade de São Paulo, São Paulo, 83-117.

Zhang N., Tian Z., Leng Y.Y, Wang H.T., Song F.Q., Meng J.H. 2007. Raman characteristics of hydrocarbon and hydrocarbon inclusions. Science in China Series D: Earth Sciences, 50(8), 1171-1178. 